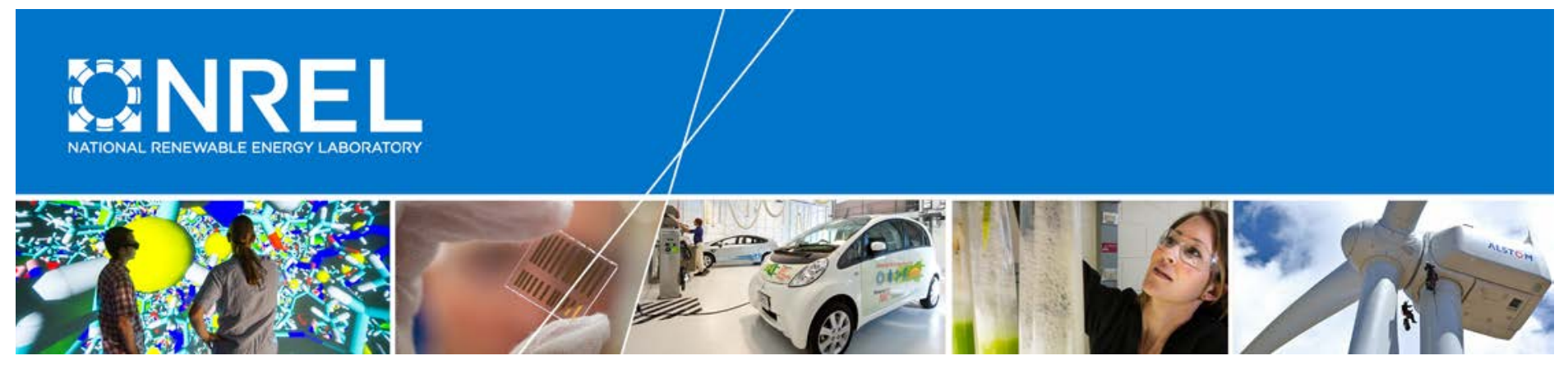

\title{
Technical Feasibility Study for Zero Energy K-12 Schools
}

Eric Bonnema, David Goldwasser, Paul Torcellini, Shanti Pless, and Daniel Studer National Renewable Energy Laboratory

NREL is a national laboratory of the U.S. Department of Energy Office of Energy Efficiency \& Renewable Energy Operated by the Alliance for Sustainable Energy, LLC

This report is available at no cost from the National Renewable Energy Laboratory (NREL) at www.nrel.gov/publications.

Technical Report

NREL/TP-5500-67233

November 2016 


\section{Technical Feasibility Study for Zero Energy K-12 Schools}

Eric Bonnema, David Goldwasser, Paul Torcellini, Shanti Pless, and Daniel Studer National Renewable Energy Laboratory

Prepared under Task No. BE6C9303
NREL is a national laboratory of the U.S. Department of Energy Office of Energy Efficiency \& Renewable Energy Operated by the Alliance for Sustainable Energy, LLC

This report is available at no cost from the National Renewable Energy Laboratory (NREL) at www.nrel.gov/publications.

\section{Technical Report}

NREL/TP-5500-67233

November 2016

Contract No. DE-AC36-08G028308
National Renewable Energy Laboratory 15013 Denver West Parkway 303-275-3000 • www.nrel.gov 


\section{NOTICE}

This report was prepared as an account of work sponsored by an agency of the United States government. Neither the United States government nor any agency thereof, nor any of their employees, makes any warranty, express or implied, or assumes any legal liability or responsibility for the accuracy, completeness, or usefulness of any information, apparatus, product, or process disclosed, or represents that its use would not infringe privately owned rights. Reference herein to any specific commercial product, process, or service by trade name, trademark, manufacturer, or otherwise does not necessarily constitute or imply its endorsement, recommendation, or favoring by the United States government or any agency thereof. The views and opinions of authors expressed herein do not necessarily state or reflect those of the United States government or any agency thereof.

This report is available at no cost from the National Renewable Energy Laboratory (NREL) at www.nrel.gov/publications.

Available electronically at SciTech Connect http:/www.osti.gov/scitech

Available for a processing fee to U.S. Department of Energy and its contractors, in paper, from:

U.S. Department of Energy

Office of Scientific and Technical Information

P.O. Box 62

Oak Ridge, TN 37831-0062

OSTI http://www.osti.gov

Phone: 865.576.8401

Fax: 865.576.5728

Email: reports@osti.gov

Available for sale to the public, in paper, from:

U.S. Department of Commerce

National Technical Information Service

5301 Shawnee Road

Alexandria, VA 22312

NTIS http://www.ntis.gov

Phone: 800.553 .6847 or 703.605 .6000

Fax: 703.605.6900

Email: orders@ntis.gov 


\section{Acknowledgments}

The authors thank Solome Girma and Cody Taylor of the U.S. Department of Energy Building Technologies Office for their leadership, guidance, and support. This report was prepared by the Commercial Buildings Group of the National Renewable Energy Laboratory (NREL) Buildings and Thermal Systems Center.

The authors extend their thanks to their NREL colleague Rois Langner, Ren Anderson from EigenEnergy LLC, and Kent Peterson from P2S Engineering for peer reviews. The authors also thank Maureen McIntyre for editorial assistance. Additionally, the authors thank Henry Gross and Steve Hudson from Hydro-Temp Corporation for providing heat pump performance data from which EnergyPlus tables could be generated.

Finally, other NREL colleagues provided valuable guidance and information during the modeling process, either directly or through their past work. Jennifer Scheib and Edwin Lee provided technical support. 


\section{List of Acronyms}

Btu

C

c.i.

CFM

COP

DCV

DOAS

DOE

EER

EF

ERV

EUI

$\mathrm{F}$

$\mathrm{ft}$

$\mathrm{ft}^{2}$

gal

GSHP

$\mathrm{h}$

HVAC

in.

$\mathrm{kW}$

$\mathrm{kWh}$

LED

LEED $^{\text {TM }}$

LPD

$\mathrm{m}$

$\min$

NREL

$\mathrm{Pa}$

PSZ

PV

SHGC

SWH

VAV

VFD

VLT

W

W.c.

ZEB
British thermal unit as measured at the building site Celsius, centigrade continuous insulation cubic feet per minute coefficient of performance demand-controlled ventilation dedicated outdoor air system U.S. Department of Energy energy efficiency ratio energy factor energy-recovery ventilator energy use intensity

Fahrenheit

foot/feet

square foot

gallon

ground source heat pump

hour

heating, ventilating, and air conditioning inch

kilowatt

kilowatt hour

light-emitting diode

Leadership in Energy and Environmental Design ${ }^{\mathrm{TM}}$

lighting power density

meter

minute

National Renewable Energy Laboratory

Pascal

packaged single zone

photovoltaic

solar heat gain coefficient

service water heating

variable air volume

variable-frequency drive

visible light transmittance

watt

water column

zero energy building 


\section{Executive Summary}

\section{Background}

This technical feasibility study provides documentation and research results supporting a possible set of strategies to achieve source zero energy $\mathrm{K}-12$ school buildings according to the definition of a zero energy building (ZEB) by the U.S. Department of Energy (DOE). Under this definition, a ZEB is "an energy-efficient building where, on a source energy basis, the actual annual delivered energy is less than or equal to the on-site renewable exported energy" (DOE 2015a). The key barrier that this work addresses is the perception that zero energy K-12 schools are not technically achievable today because the technologies are not available or-if they aredesign teams lack the knowledge to implement them. Budget constraints are a key piece of any project, so this study uses typical construction practices and equipment to develop affordable solutions to the challenges of designing and building ZEB K-12 schools. The key to delivering ZEB projects at a competitive cost is careful management of the procurement process from the outset and the integration of architecture, engineering, and construction practices. Although not comprehensive, the case studies and industry review in this document provide evidence that the suggested solutions are technically viable and could be employed today at a reasonable cost.

Detailed energy simulation analyses were performed with OpenStudio, using the EnergyPlus simulation engine, across U.S. climate zones with a variety of systems and building parameters to arrive at a pathway that meets the zero energy goal. This document describes the applicability of zero energy in the United States and discusses the parameters used to characterize the buildings.

\section{Scope}

This feasibility study applies to elementary, middle, and high school buildings. Its primary focus is new construction, but the findings may be applicable to facilities undergoing major renovations. Some approaches discussed in this document may also be appropriate for $\mathrm{K}-12$ schools undergoing less comprehensive renovation, addition, remodeling, and modernization projects (including changes to one or more systems in existing buildings). The same analysis approach can be applied to major renovations, with the limitation that design flexibility in a major renovation may be restricted compared to the design of a new school.

Schools typically include some or all of these space types:

- Administrative and offices

- Classrooms, hallways, and restrooms

- Gymnasiums with locker rooms and showers

- Assembly spaces with either flat or tiered seating

- Food preparation spaces

- Libraries or media centers.

This study does not consider specialty spaces such as indoor pools, wet laboratories (e.g., chemistry), "dirty" dry laboratories (e.g., woodworking and auto shops), or other unique spaces that generate extraordinary heat or require large amounts of ventilation. This does not mean that 
it is not possible to achieve zero energy if a school includes these space types; rather, this analysis approach could be extended to include $\mathrm{K}-12$ schools that have these spaces. This would most likely require additional renewable energy generation, such as photovoltaic (PV) panels on parking lots or awnings.

The design process in this report focuses on zero energy $\mathrm{K}-12$ schools. It would also be useful, however, for any team designing a school that integrates energy efficiency and renewable energy generation to achieve the highest energy savings possible within the constraints of the project's construction and operating budgets.

This study looks at only the energy consumption aspects of $\mathrm{K}-12$ schools and the potential for on-site renewable resources to meet energy loads. It does not address other sustainability or design issues such as acoustics, productivity, indoor air quality, water efficiency, landscaping, and transportation except as they relate to energy use. It does meet ASHRAE Standard 55-2013 (2013a) and ASHRAE Standard 62.1-2007 (2007) for thermal comfort and outside air requirements as part of the energy modeling parameters. In addition, the models meet or exceed ASHRAE Standard 90.1-2013 (2013b) for energy efficiency in commercial buildings. As a result, this feasibility study contains pathways for zero energy schools, but it is not a recommendation guide nor intended to be used as a code or standard.

\section{Evaluation Approach and Results}

The building energy simulation analysis was conducted to assess and quantify the energy consumption for a school as well as to determine the amount of solar energy converted into electricity by PV panels within the building footprint. Analyses were performed for each of the U.S. climate zones.

The following steps describe how the energy savings potential was determined.

1. Develop "typical" $\mathrm{K}-12$ school facility prototypes.

A typical prototype is an energy model that is a representative example of a $\mathrm{K}-12$ school facility. The primary and secondary school DOE Commercial Prototype Building Models (DOE 2014) were used as the typical prototype for space layouts and space types. Because of different space types and configurations, different models were used to represent these buildings. Many areas of the United States also have middle schools that typically fall between primary and secondary schools in terms of space type. Middle schools do not need to be modeled separately to determine their feasibility as zero energy schools. The high-level characteristics for the two prototypes are shown in Table 1. 
Table 1. Feasibility Study Prototype Characteristics

\begin{tabular}{|c|c|c|}
\hline Building Characteristic & Feasibility Study Prototype & \\
\hline Building type & Primary school & Secondary school \\
\hline Size $\left(\mathrm{ft}^{2}\right)$ & 82,500 & 227,700 \\
\hline Number of floors & 2 & 3 \\
\hline Number of students & 650 & 1,200 \\
\hline Space types & $\begin{array}{l}\text { Art classroom, cafeteria, } \\
\text { classroom, corridor, multipurpose } \\
\text { room, kitchen, lobby, mechanical } \\
\text { room, media center, office, } \\
\text { restrooms }\end{array}$ & $\begin{array}{l}\text { Art classroom, auditorium, } \\
\text { cafeteria, classroom, corridor, } \\
\text { gyms, kitchen, library, lobby, } \\
\text { mechanical room, office, restrooms }\end{array}$ \\
\hline Wall construction & Steel-framed & Steel-framed \\
\hline Roof construction & Insulation entirely above deck & Insulation entirely above deck \\
\hline Window area & $35 \%$ window to gross wall area & $35 \%$ window to gross wall area \\
\hline Percentage conditioned & Fully heated and cooled & Fully heated and cooled \\
\hline $\begin{array}{l}\text { Heating, ventilating, and } \\
\text { air-conditioning (HVAC) } \\
\text { system types }\end{array}$ & $\begin{array}{l}\text { Multizone variable air volume } \\
\text { (VAV) dedicated outdoor air system } \\
\text { (DOAS) with zone-level ground } \\
\text { source heat pump (GSHP) in } \\
\text { classroom wings and common } \\
\text { areas; packaged single-zone } \\
\text { GSHPs in gym, kitchen, cafeteria }\end{array}$ & $\begin{array}{l}\text { Multizone VAV DOAS with zone- } \\
\text { level GSHP in classroom wings } \\
\text { and common areas; packaged } \\
\text { single-zone GSHPs in gyms, } \\
\text { kitchen, cafeteria, auditorium }\end{array}$ \\
\hline
\end{tabular}

2. Determine energy use intensity allowances based on solar availability for the prototypical buildings.

Solar radiation calculations at the site were used to determine the amount of energy available to the school on an annual basis. Although not an absolute goal, these estimates provided a target for energy consumption in the building to help guide the process of determining and meeting the energy loads. Although this step came first, the focus of this study was on the energy efficiency of the building using typically available technologies.

3. Create low-energy models based on the prototypical buildings.

This study is a best-in-class look at energy efficiency for schools. The technologies and strategies were based on previous work for $50 \%$ energy reduction in schools (ASHRAE 2012) as well as current case studies of very low-energy schools. Efficiencies and equipment parameters reflect currently available approaches and technologies, including, for example:

○ Classroom orientation for a long east-west axis

○ Enhanced building opaque envelope insulation, window glazing, and overhangs

○ Reduced lighting power density (LPD) based on light-emitting diode (LED) technology

- Use of vacancy sensors to minimize lighting during non-occupied periods 
- Enhanced controls for common areas and exterior lighting based on LED technology

○ Daylighting in classrooms, resource rooms, cafeterias, gyms, and multipurpose rooms

- Exterior LPD reductions

- Plug load reductions and improved controls for shedding loads during unoccupied periods

$\bigcirc$ High-performance commercial kitchen equipment and ventilation

○ Demand-controlled ventilation and energy-recovery ventilators using dedicated outside air systems

- HVAC equipment including system configurations

○ High-efficiency service water heating equipment and distribution systems.

These energy-efficiency models established an energy use intensity (EUI) goal for the buildings in each climate zone. Table 2 summarizes the EUI targets to meet or exceed zero energy.

Table 2. EUI Targets to Meet or Exceed Zero Energy

\begin{tabular}{|c|c|c|c|c|c|}
\hline \multirow[b]{2}{*}{$\begin{array}{l}\text { Climate } \\
\text { Zone }\end{array}$} & \multirow[b]{2}{*}{$\begin{array}{l}\text { Representative } \\
\text { City }\end{array}$} & \multicolumn{2}{|c|}{ Primary School } & \multicolumn{2}{|c|}{ Secondary School } \\
\hline & & $\begin{array}{l}\text { Site Energy } \\
\left(\mathrm{kBtu}^{\prime} \mathrm{ft}^{2} \cdot \mathrm{yr}\right)\end{array}$ & $\begin{array}{l}\text { Source } \\
\text { Energy } \\
\left(\mathrm{kBtu} / \mathrm{ft}^{2} \cdot \mathrm{yr}\right)\end{array}$ & $\begin{array}{r}\text { Site Energy } \\
\left(\mathrm{kBtu} / \mathrm{ft}^{2} \cdot \mathrm{yr}\right)\end{array}$ & $\begin{array}{l}\text { Source } \\
\text { Energy } \\
\left(\mathrm{kBtu} / \mathrm{ft}^{2} \cdot \mathrm{yr}\right)\end{array}$ \\
\hline $1 \mathrm{~A}$ & Miami, FL & 25.9 & 76.4 & 23.1 & 68.5 \\
\hline $2 \mathrm{~A}$ & Houston, TX & 24.3 & 71.1 & 21.7 & 63.5 \\
\hline $2 \mathrm{~B}$ & Phoenix, AZ & 24.7 & 72.5 & 21.9 & 64.3 \\
\hline $3 A$ & Memphis, TN & 23.8 & 69.0 & 21.2 & 61.6 \\
\hline $3 B$ & El Paso, TX & 23.4 & 67.8 & 20.7 & 60.2 \\
\hline $3 C$ & San Francisco, CA & 21.6 & 61.9 & 19.0 & 54.3 \\
\hline $4 \mathrm{~A}$ & Baltimore, MD & 23.5 & 67.6 & 20.9 & 60.1 \\
\hline $4 B$ & Albuquerque, NM & 23.1 & 66.6 & 20.4 & 58.8 \\
\hline $4 \mathrm{C}$ & Salem, OR & 22.4 & 64.2 & 19.7 & 56.4 \\
\hline $5 \mathrm{~A}$ & Chicago, IL & 24.3 & 69.9 & 21.6 & 62.2 \\
\hline $5 B$ & Boise, ID & 23.2 & 66.7 & 20.4 & 58.4 \\
\hline $6 \mathrm{~A}$ & Burlington, VT & 24.5 & 70.1 & 21.6 & 61.9 \\
\hline $6 \mathrm{~B}$ & Helena, MT & 23.5 & 66.9 & 20.5 & 58.4 \\
\hline 7 & Duluth, MN & 25.9 & 74.1 & 22.8 & 65.1 \\
\hline 8 & Fairbanks, AL & 28.7 & 82.5 & 25.0 & 71.5 \\
\hline
\end{tabular}

4. Verify that the findings meet or exceed the zero energy goal of the technical feasibility study. 
In this study, energy consumption was matched to the solar potential for each climate to determine the feasibility of achieving the zero energy goal. The variable was the amount of roof area to be covered by $18 \%$ efficient solar PV panels, and the target was $50 \%$ roof coverage. To maintain consistency in the requirements of ASHRAE 90.1 and the variability of solar among the climate zones, there was fluctuation in the percentage requirements. Temperate climates require a smaller percentage of solar panel coverage than very hot or very cold climates. Although not ideal, the extremely cold climates (Climate Zone 8) required that solar panels be installed on-site but outside the building footprint. Figure 1 and Figure 2 show the roof PV coverage percentage required to achieve zero energy in different climate zones.

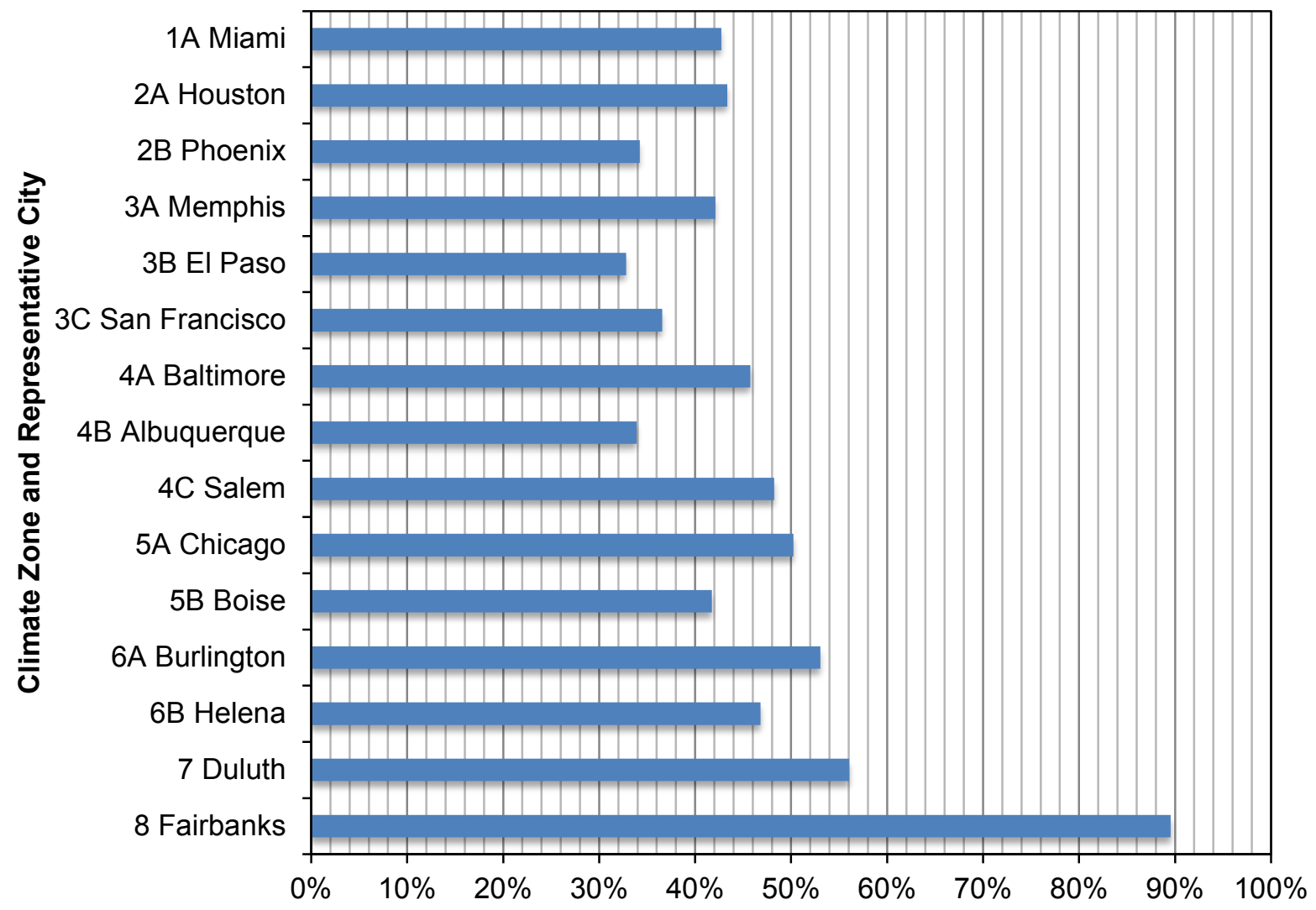

Figure 1. Rooftop PV coverage percentage to achieve zero energy-primary school. 


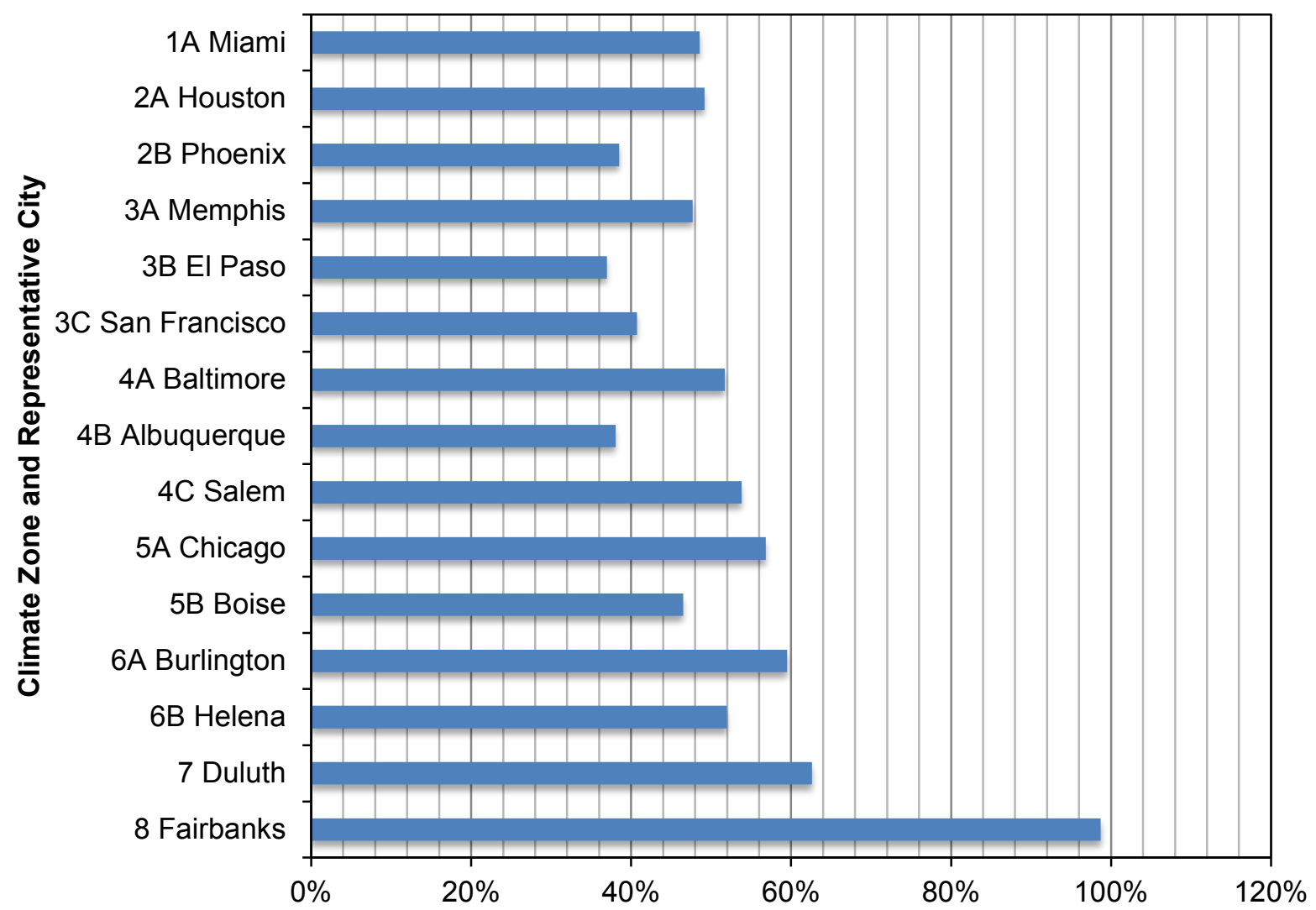

Figure 2. Rooftop PV coverage percentage to achieve zero energy-secondary school.

Image from Eric Bonnema and David Goldwasser, NREL

\section{Zero Energy Verification}

All schools can benefit from the results of this feasibility analysis. The analysis shows target EUIs that are independent of the amount of solar installed on the building, but it recognizes that if solar is placed on these buildings in the amounts specified, then the DOE ZEB definition can be met. In climate zones 1 through 6 , zero energy can be achieved with less than $50 \%$ of the rooftop dedicated to solar panels, an achievable objective for most commercial buildings. In the colder climates of 7 and 8 , additional space is needed due to larger heating loads as well as diminished solar availability. 


\section{Table of Contents}

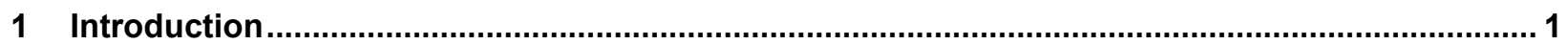

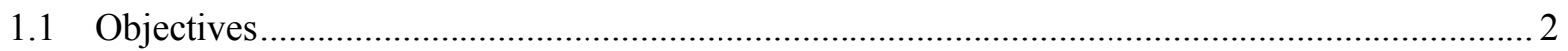

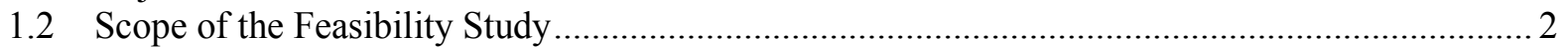

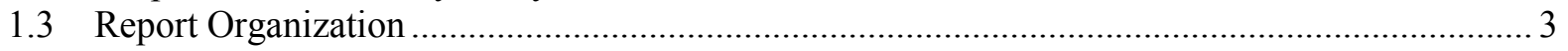

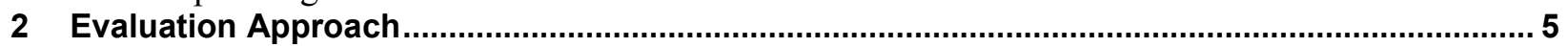

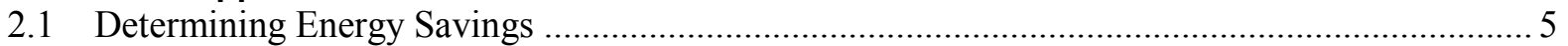

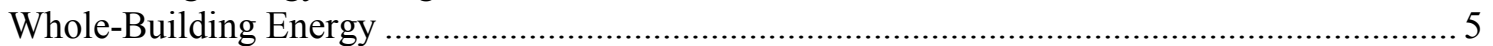

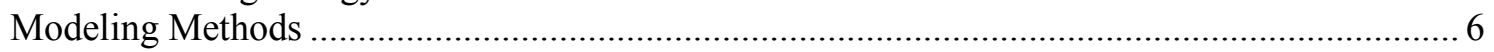

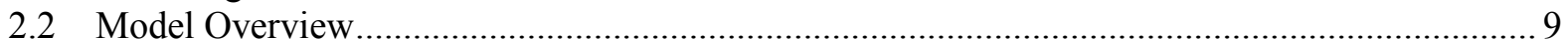

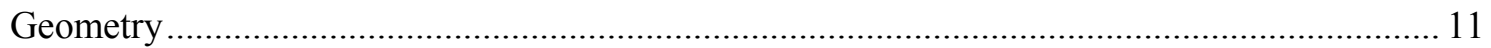

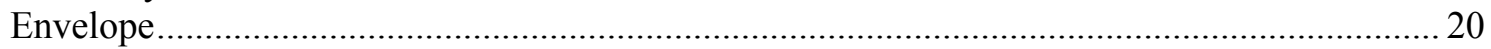

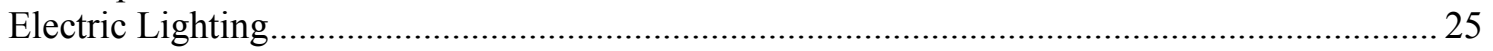

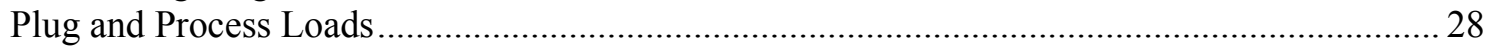

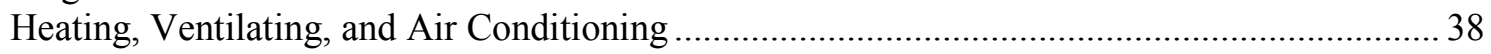

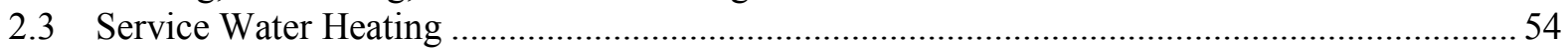

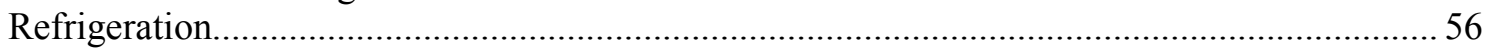

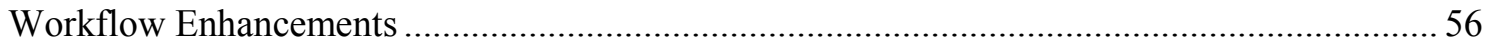

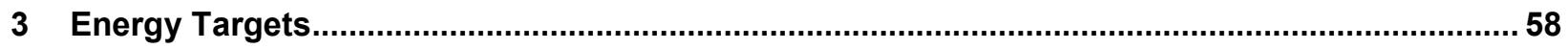

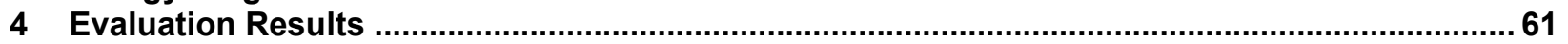

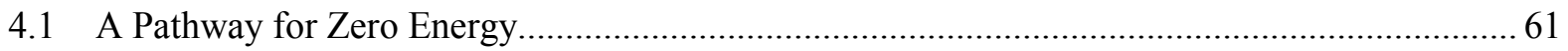

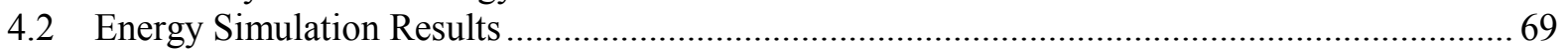

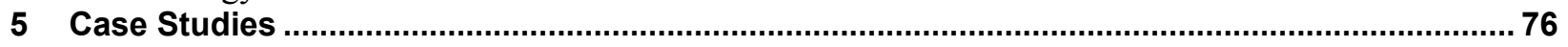

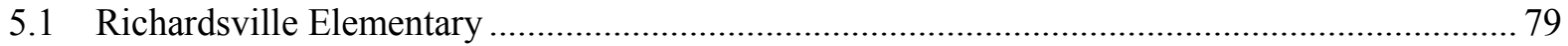

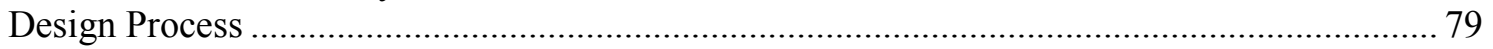

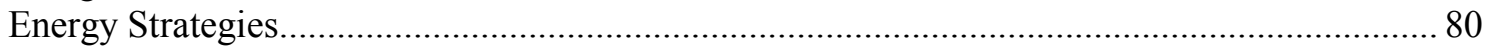

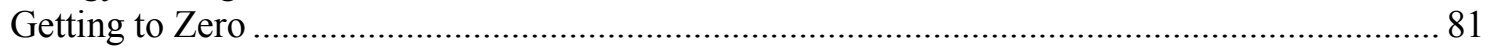

Costs 81

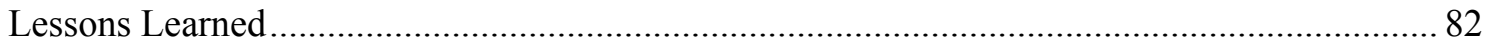

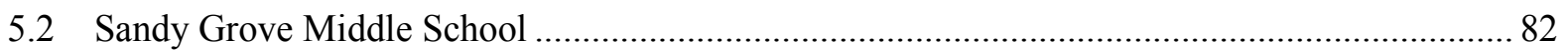

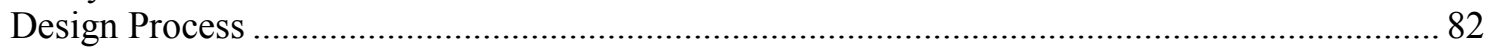

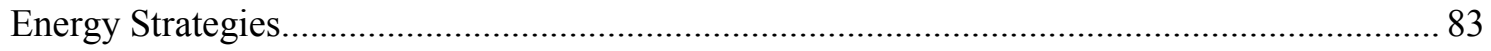

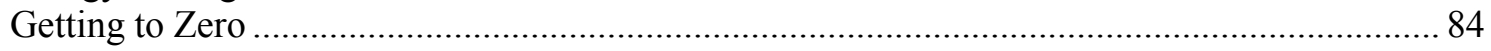

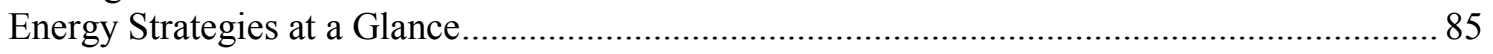

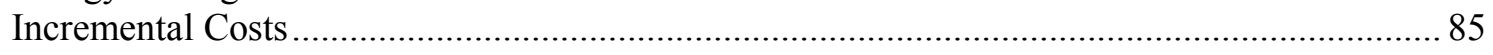

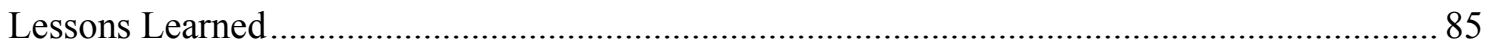

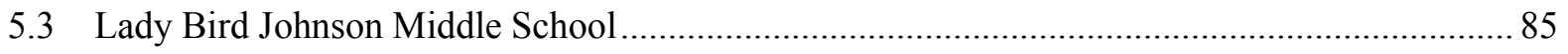

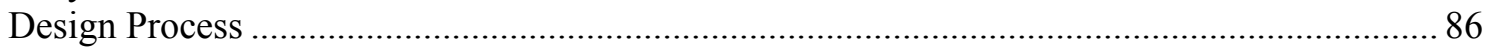

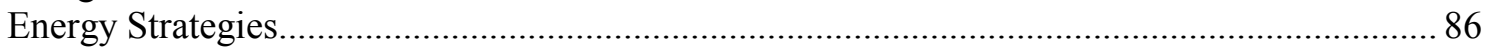

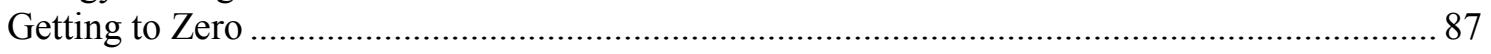

Costs 88

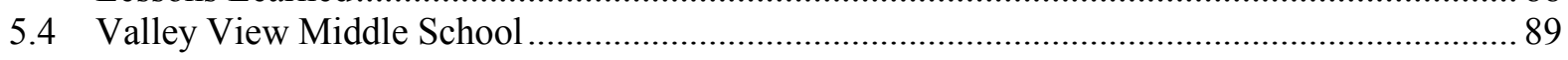

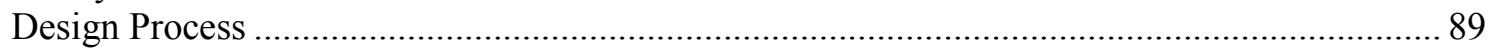

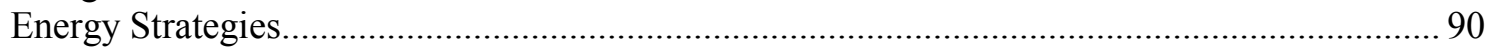

Costs 91

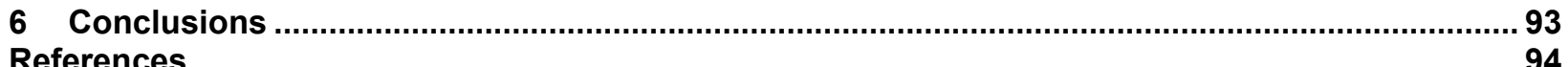

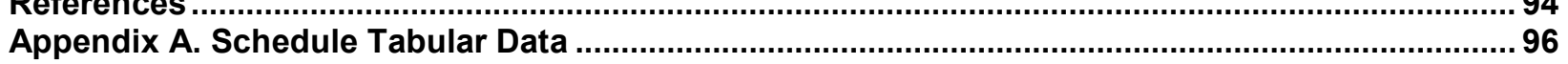

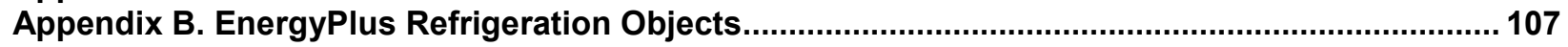

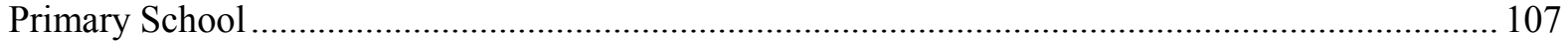




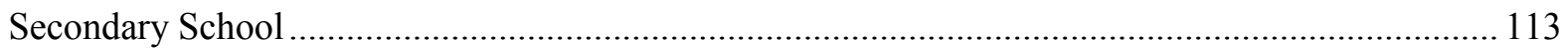

Appendix C. EnergyPlus Heat Pump Performance Tables ...................................................... 120

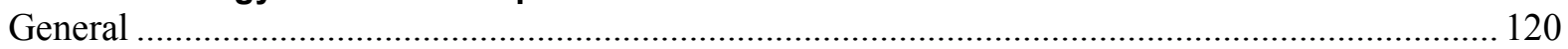

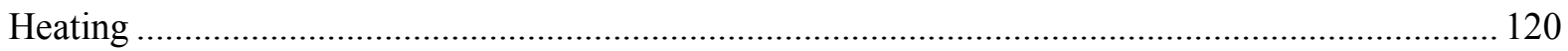

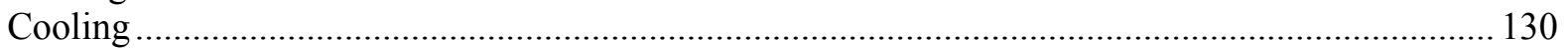




\section{List of Figures}

Figure 1. Rooftop PV coverage percentage to achieve zero energy - primary school.............................ix

Figure 2. Rooftop PV coverage percentage to achieve zero energy — secondary school........................... $\mathrm{x}$

Figure 3. Schematic showing boundaries and energy flows for the building ........................................ 6

Figure 4. Climate zones and representative cities .............................................................................. 8

Figure 5. Primary school energy model rendering.......................................................................... 9

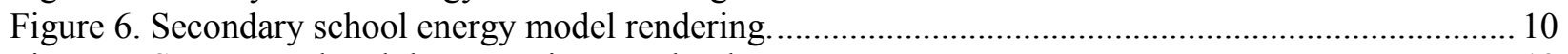

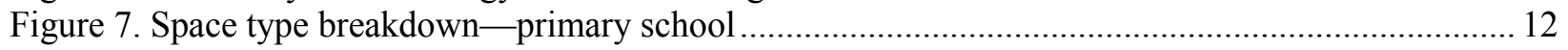

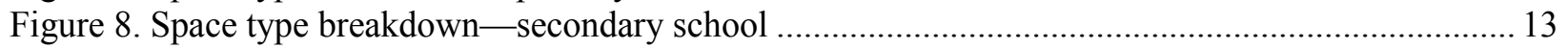

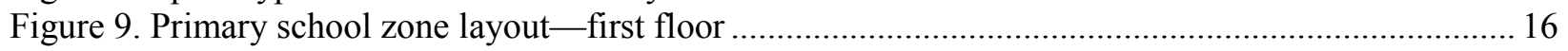

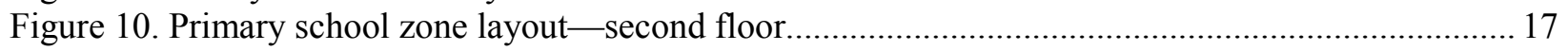

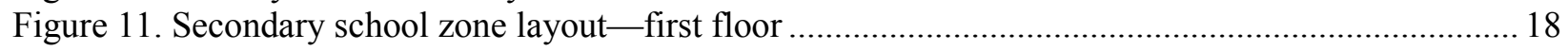

Figure 12. Secondary school zone layout—second floor............................................................... 19

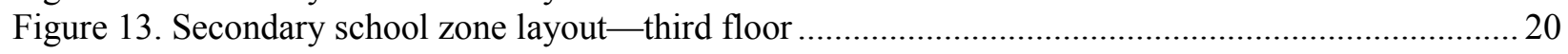

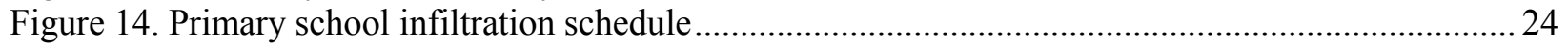

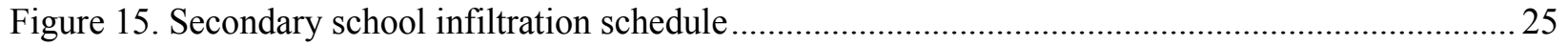

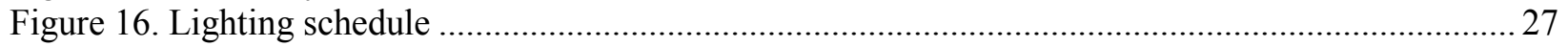

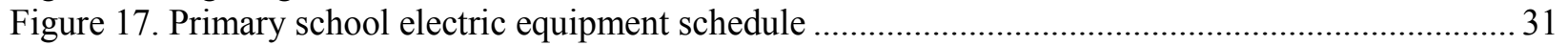

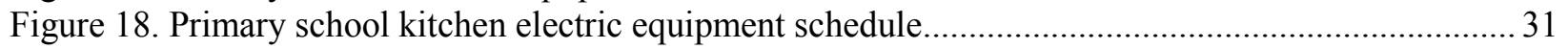

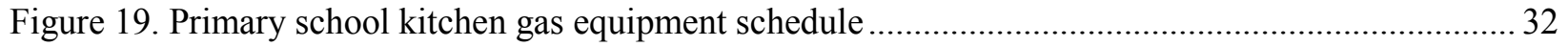

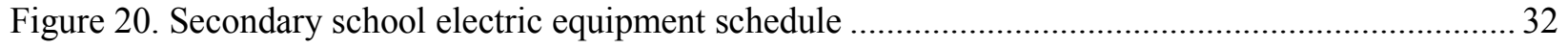

Figure 21. Secondary school kitchen electric equipment schedule........................................................ 33

Figure 22. Secondary school zero kitchen gas equipment schedule ..................................................... 33

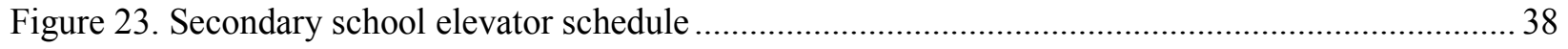

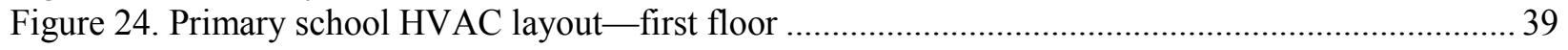

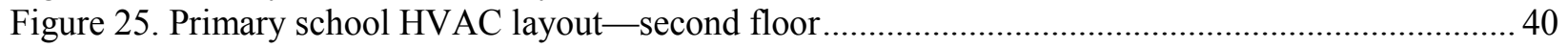

Figure 26. Secondary school HVAC layout—first floor ................................................................ 41

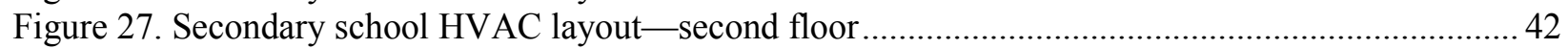

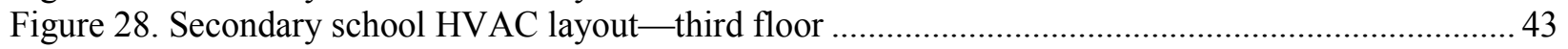

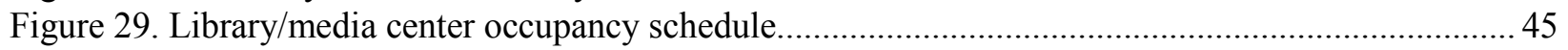

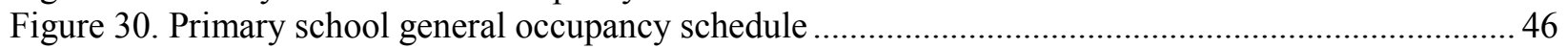

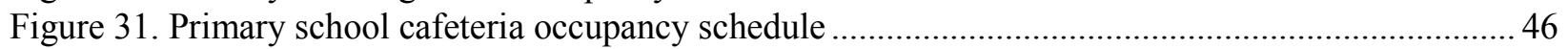

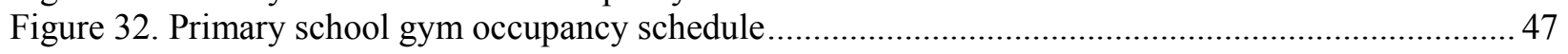

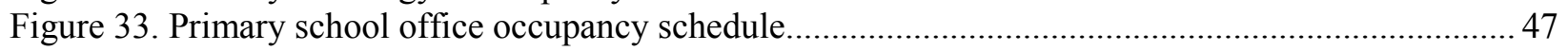

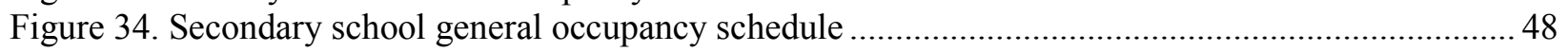

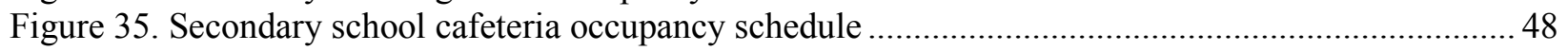

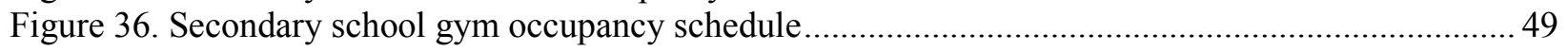

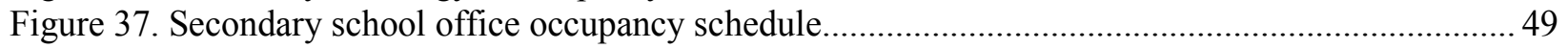

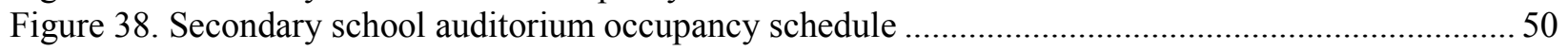

Figure 39. Secondary school auxiliary gym occupancy schedule.................................................. 50

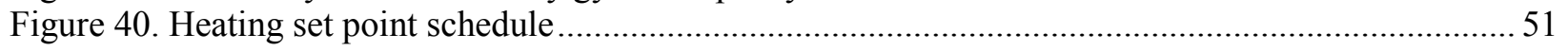

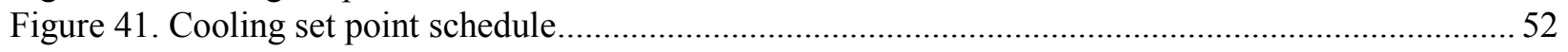

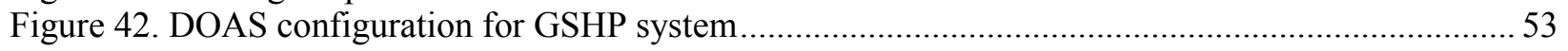

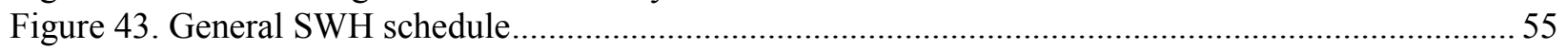

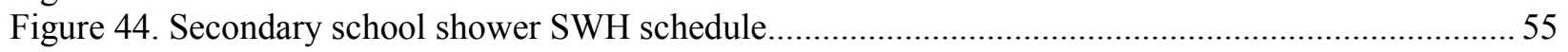

Figure 45. Site energy intensity values for zero energy — primary school............................................ 70

Figure 46. Source energy intensity values for zero energy — primary school........................................ 71

Figure 47. Site energy intensity values for zero energy — secondary school. ........................................ 72

Figure 48. Source energy intensity values for zero energy — secondary school. ................................... 73

Figure 49. Rooftop PV coverage percentage to achieve zero energy - primary school. .......................... 74 
Figure 50. Rooftop PV coverage percentage to achieve zero energy — secondary school....................... 75

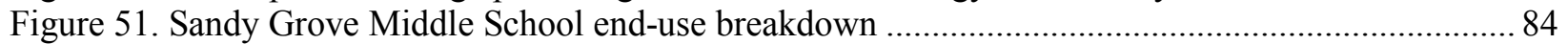

\section{List of Tables}

Table 1. Feasibility Study Prototype Characteristics ............................................................................ vii

Table 2. EUI Targets to Meet or Exceed Zero Energy ............................................................................... viii

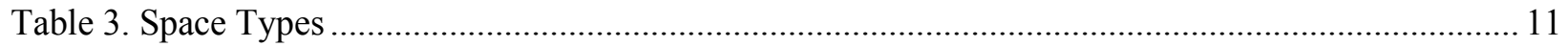

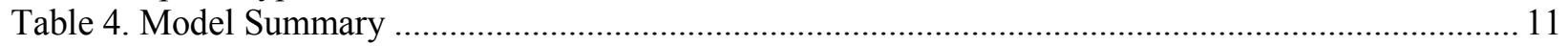

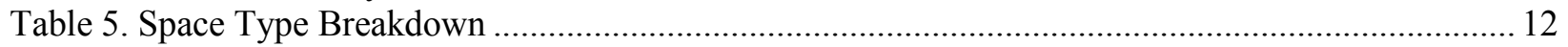

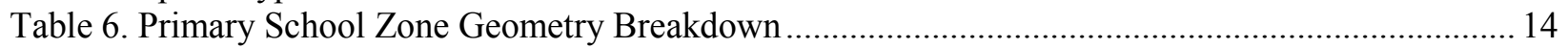

Table 7. Secondary School Zone Geometry Breakdown ...................................................................... 15

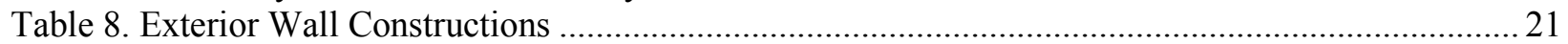

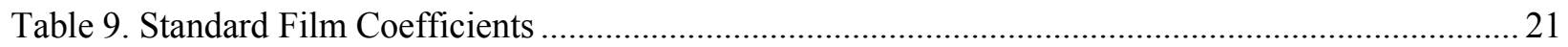

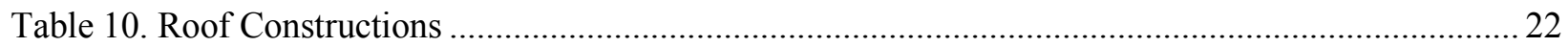

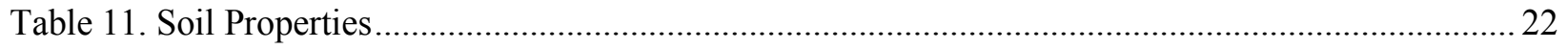

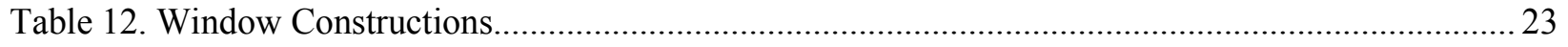

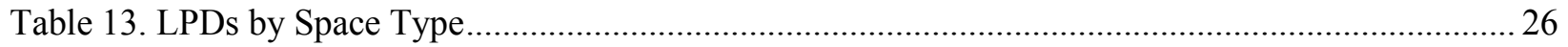

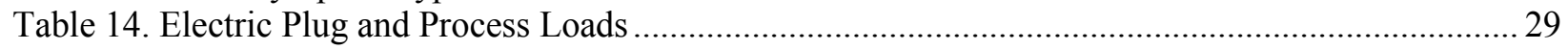

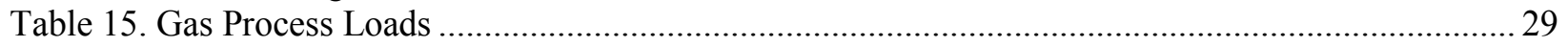

Table 16. Primary School Kitchen Load Profile_Electric Equipment ................................................... 35

Table 17. Secondary School Kitchen Load Profile_Electric Equipment ................................................ 36

Table 18. Primary School Kitchen Load Profile — Gas Equipment .......................................................... 37

Table 19. Secondary School Kitchen Load Profile — Gas Equipment ....................................................... 37

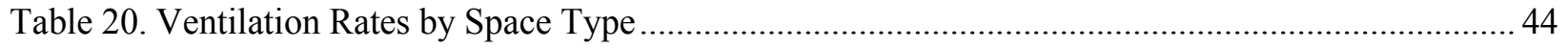

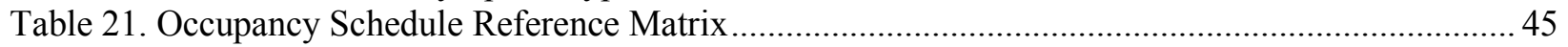

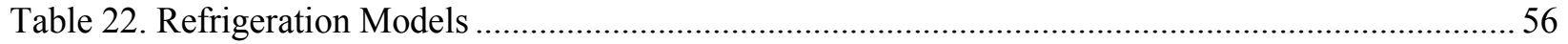

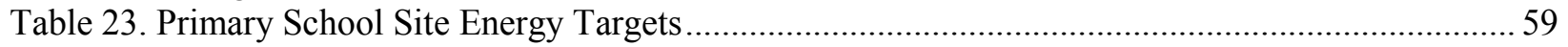

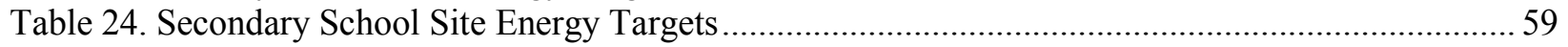

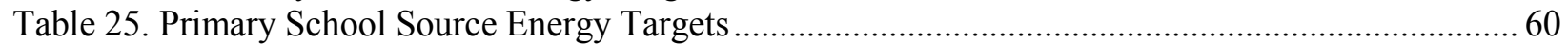

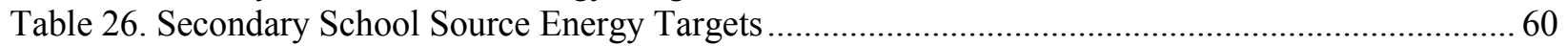

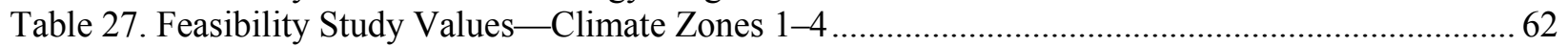

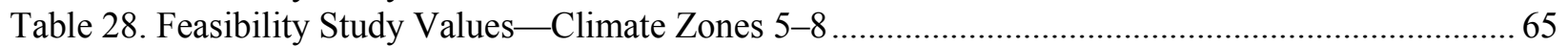

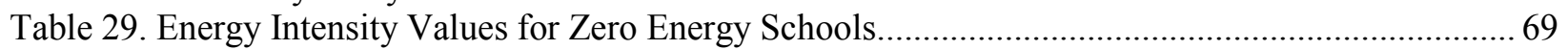

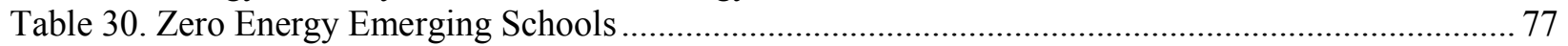

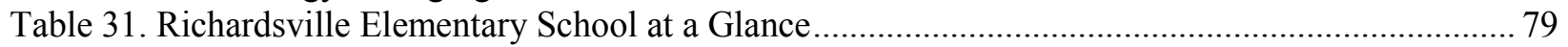

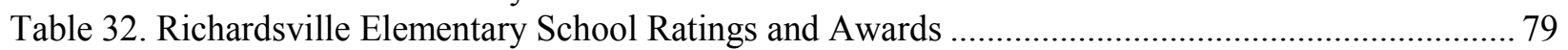

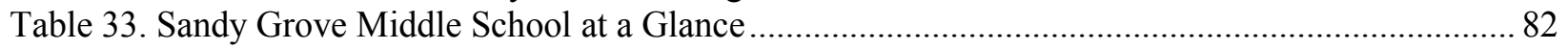

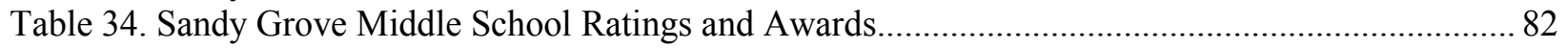

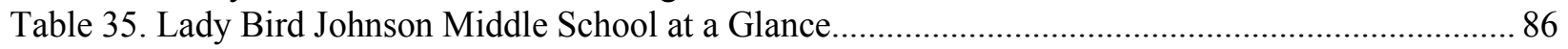

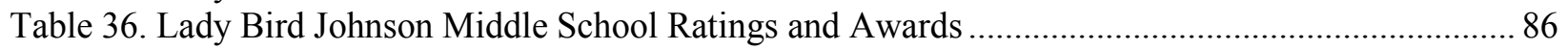

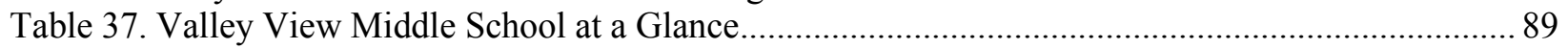

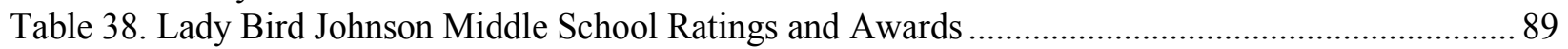

Table 39. Library/Media Center Occupancy Schedule .......................................................................... 96

Table 40. Primary School General Occupancy Schedule ................................................................ 96

Table 41. Primary School Cafeteria Occupancy Schedule .................................................................. 96

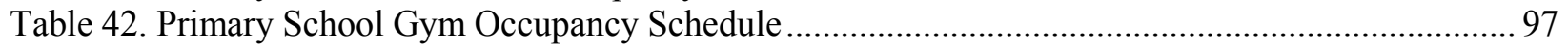

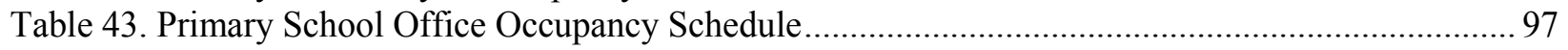

Table 44. Secondary School General Occupancy Schedule ................................................................ 97

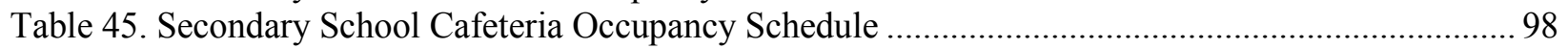

Table 46. Secondary School Gym Occupancy Schedule ..................................................................... 98 
Table 47. Secondary School Office Occupancy Schedule.................................................................. 98

Table 48. Secondary School Auditorium Occupancy Schedule ............................................................. 99

Table 49. Secondary School Auxiliary Gym Occupancy Schedule...................................................... 99

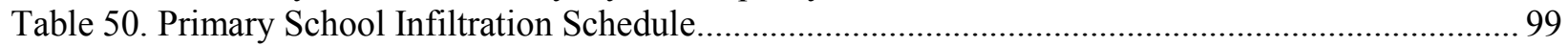

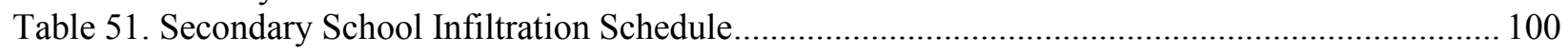

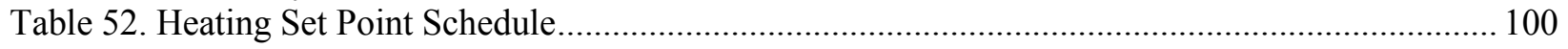

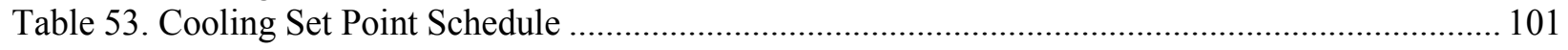

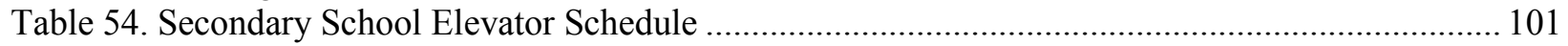

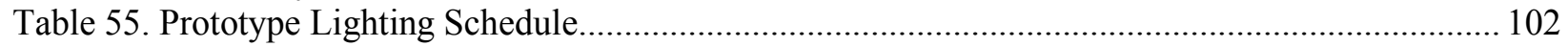

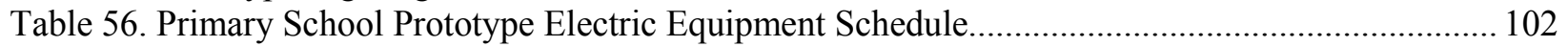

Table 57. Primary School Prototype Kitchen Electric Equipment Schedule ........................................... 102

Table 58. Primary School Prototype Kitchen Gas Equipment Schedule ................................................ 103

Table 59. Secondary School Prototype Electric Equipment Schedule...................................................... 103

Table 60. Secondary School Prototype Kitchen Electric Equipment Schedule ....................................... 103

Table 61. Secondary School Prototype Kitchen Gas Equipment Schedule ............................................. 104

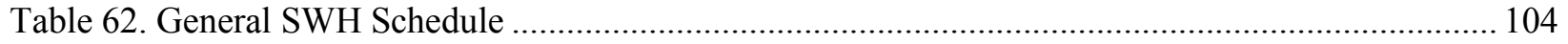

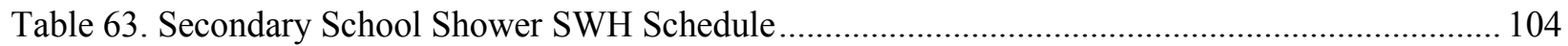

Table 64. Primary School Zero Energy Electric Equipment Schedule ................................................. 105

Table 65. Primary School Zero Energy Kitchen Electric Equipment Schedule ..................................... 105

Table 66. Primary School Zero Energy Kitchen Gas Equipment Schedule............................................ 105

Table 67. Secondary School Zero Energy Electric Equipment Schedule .............................................. 106

Table 68. Secondary School Zero Energy Kitchen Electric Equipment Schedule ................................ 106

Table 69. Secondary School Zero Energy Kitchen Gas Equipment Schedule......................................... 106 


\section{Introduction}

Commercial buildings currently account for approximately $17 \%$ of U.S. energy consumption. Despite advancements in energy efficiency, the absolute amount of energy use continues to grow because the building stock is increasing faster than the energy-efficiency strategies are being deployed. To make substantial progress toward reducing the absolute amount of energy consumed by commercial buildings, buildings need to produce as much energy as they consume. To this end, the U.S. Department of Energy (DOE) released a common definition for zero energy buildings (ZEBs) that defines a ZEB as "an energy-efficient building where, on a source energy basis, the actual annual delivered energy is less than or equal to the on-site renewable exported energy" (DOE 2015a).

An assessment of the potential for achieving ZEBs across the entire building stock was completed in 2006 and showed that low-rise buildings had more opportunity to achieve zero energy status (Griffith et al. 2006). In some building types, such as hospitals, it was very difficult to achieve the goal; whereas others, such as warehouses, could easily achieve ZEB status. As the zero energy concept becomes better understood in the marketplace, there is a need to publish case studies and provide further evidence that ZEBs are possible within typical construction budgets.

$\mathrm{K}-12$ schools have been an energy-efficiency leader for the building industry. They have strong community involvement and tend to be catalysts for change. Because they are owner-occupied, investments are made for durability and low operating costs in their design and construction. They comprise diverse space types and are typically fewer than three stories. They are "public" buildings and make excellent case studies for the entire construction industry. Although schools are not the easiest buildings in which to achieve zero energy, they provide a good initial pathway into the commercial buildings industry.

The long-range goal would be to create an environment in which all $\mathrm{K}-12$ schools could be designed and operated such that they meet the DOE definition of a ZEB. The first steps are to determine the technical feasibility of zero energy in the $\mathrm{K}-12$ school sector and to identify the technologies and methodologies needed to achieve the goal. The feasibility is validated with actual case studies of very high-performing schools. The strategy is to apply a robust set of energy-efficiency strategies that are beyond current codes and standards, creating energy use intensity (EUI) targets that can then be met with renewable generation. The focus is on minimizing waste through increased energy efficiency before producing more energy.

This feasibility study provides the technical support to show that $\mathrm{K}-12$ schools can become ZEBs within their own footprint using on-site renewable generation as specified by the DOE definition. It can serve as a foundation for those involved in designing, constructing, and renovating schools to make a substantial difference and those who assume a leadership role in transforming buildings to producers, rather than consumers, of energy.

Depending on the individual school districts, grades are divided into elementary or primary schools (grades K-5), middle schools (grades 6-8), and high or secondary schools (grades 9-12). Regarding renewable generation potential, middle schools typically fall between primary and secondary schools. As a result, this feasibility study examines primary and secondary schools. 
The focus of this study is on the energy consumption of the buildings. Energy consumption targets are determined such that on-site renewable resources can meet a building's energy needs. Climate-appropriate design strategies are developed to serve as pathways to achieving the target EUI. The pathways include strategies for reducing consumption, including the design of the building envelope; fenestration; lighting systems (including electric lights and daylighting); heating, ventilating, and air-conditioning (HVAC) systems; controls; and service water heating $(\mathrm{SWH})$.

The goal is to show that zero energy schools are achievable using typical construction techniques. As a feasibility study, this document is not intended to provide design guidance; rather, it can provide pathways and directions that could lead to the widespread deployment of zero energy schools. Because of the balance of energy consumption and energy supply required to achieve zero energy, the focus of this report is on establishing energy consumption targets for K-12 schools such that on-site renewable energy can meet the load. The analysis for determining the amount of energy available is not complex, but achieving the low energy requirements involves assessing many options and is complex to analyze.

The concept of zero energy is relatively new, and design guidance is not widespread; thus, existing case studies are limited, and those that exist were highly customized for particular school applications. Nevertheless, case studies serve as a springboard to show that the feasibility study has merit and can be extended beyond a few select buildings. They are also indications that the industry can move toward zero energy schools even though very few case studies exist yet. The important point is that many schools are achieving EUIs such that PV could meet the load.

This feasibility study was designed such that a workflow could be developed in parallel with existing software tools. This was done to better understand the limitations of these tools and determine the improvements that are needed so that support mechanisms are widely available to deliver zero energy schools.

\subsection{Objectives}

This feasibility study was developed to describe the strategies necessary to achieve zero energy school buildings:

- Document the EnergyPlus and OpenStudio modeling assumptions used to establish EUI goals such that zero energy is possible.

- Document the zero energy simulation school models.

- Demonstrate that the strategies result in source zero energy by climate zone.

- Document limitations in the OpenStudio workflows that if remedied would greatly simplify the process of evaluating design strategies that move a building toward zero energy.

\subsection{Scope of the Feasibility Study}

This study applies to elementary, middle, and high school buildings. Its primary focus is new construction, but these findings may be applicable to facilities undergoing major renovations. Some approaches discussed in this document may also be appropriate for $\mathrm{K}-12$ schools 
undergoing less comprehensive renovations, additions, remodeling, and modernization projects (including changes to one or more systems in existing buildings). The same analysis approach can be applied to major renovations, with the limitation that design flexibility in a major renovation may be restricted compared to the design of a new school.

Schools typically include some or all of the following space types:

- Administrative and offices

- Classrooms, hallways, and restrooms

- Gymnasiums with locker rooms and showers

- Assembly spaces with either flat or tiered seating

- Food preparation spaces

- Libraries or media centers.

Specialty spaces such as indoor pools, wet laboratories (e.g., chemistry), "dirty" dry laboratories (e.g., woodworking and auto shops), or other unique spaces that generate extraordinary heat or require large amounts of ventilation are not considered in this study. This does not mean that it is not possible to achieve zero energy if a school includes these space types; rather, this analysis approach could be extended to include $\mathrm{K}-12$ schools that have these space types. This would most like require additional renewable energy generation, such as PV panels on parking structures or awnings.

The design process in this report focuses on zero energy $\mathrm{K}-12$ schools. It would also be useful, however, for any design team designing a school that integrates energy efficiency and renewable energy generation to achieve the highest energy savings possible within the constraints of the project's construction and operating budgets.

In addition, this study only looks at the energy consumption aspects of K-12 schools and the ability for on-site renewable resources to meet those energy loads. It does not address other sustainability or design issues such as acoustics, productivity, indoor air quality, water efficiency, landscaping, and transportation except as they relate to energy use. It does meet ASHRAE Standard 55-2013 (ASHRAE 2013a) and ASHRAE Standard 62.1-2007 (ASHRAE 2007) for thermal comfort and outside air requirements as part of the energy modeling parameters. In addition, the models meet or exceed ASHRAE Standard 90.1-2013 (ASHRAE 2013b) for energy efficiency in commercial buildings. As a result, this feasibility study contains pathways for zero energy schools, but it is not intended to offer recommendations on particular pieces of equipment or to be used as a code or standard.

\subsection{Report Organization}

This report is presented in six sections. Section 1 introduces the feasibility study and the supporting background information; Section 2 provides the evaluation approach, including modeling methods and assumptions, with Section 2.2.8 discussing modeling workflow enhancements; Section 3 examines the development of energy targets and directions for future goal setting; Section 4 documents the most effective strategies the study identified; Section 5 presents four zero source energy K-12 school case studies; and Section 6 discusses conclusions. 
Appendix A contains tabular data of the schedules used in the energy models, Appendix B contains EnergyPlus input data file snippets of the refrigeration models, and Appendix $\mathrm{C}$ contains EnergyPlus input data file snippets of the heat pump performance tables. 


\section{Evaluation Approach}

Creating energy models to study the energy performance of school buildings and matching this energy performance to models for energy generation from solar PV was important to determining the feasibility of zero energy schools. This section describes the analysis methods used, including the development of the energy simulation models and the methods used to determine whether the DOE ZEB definition had been met.

\subsection{Determining Energy Savings}

The purpose of the building energy simulation analysis is to determine what set of energyefficiency strategies is needed to achieve an energy consumption figure that matches the solar energy resource available within the building footprint. The set of energy-efficiency strategies covers all eight U.S. climate zones (Briggs, Lucas, and Taylor 2003) and their corresponding subzones (resulting in 15 total climate locations).

The following steps were used to determine that the goal of zero energy was met or exceeded:

- Develop “typical” K-12 school prototype characteristics (which may result in multiple prototypical models).

- Use energy modeling iteratively to create parameters that can achieve zero energy. These parameters must also meet the minimum requirements of ASHRAE 90.1-2013 (ASHRAE $2013 \mathrm{~b}$ ) as well as be consistent within the climate zone and among climate zones.

- Verify zero energy was achieved among the eight U.S. climate zones and corresponding subzones.

These steps are presented in a linear fashion while acknowledging that the process of arriving at the final result involved iterations and parallel workflows.

\section{Whole-Building Energy}

Energy is measured based on a specific defined boundary. Whole-building performance is expressed by the amount of purchased energy that crosses the building site boundary. When onsite solar generation is added to the mix, this on-site generation offsets the building energy consumption as measured at the site boundary. To decouple this, energy consumption is separated from renewable energy production.

The DOE definition for a ZEB uses source energy as a metric. This takes the energy flows at the site boundary and applies a site-to-source conversion to approximate the inefficiencies of delivering the energy from the point of extraction to the site. This feasibility study uses the conversion factors in the definition document (DOE 2015a), which are from ASHRAE Standard 105 Table J2-A (ASHRAE 2014).

Figure 3 shows the energy flows and boundaries schematically. To measure the energy consumption of the building, Boundary A is used assuming no energy from the PV system. This site energy number is multiplied by the site-to-source ratio for each fuel source to represent the energy content in the fuel extraction and transmission/distribution losses. For the purposes of a 
zero energy school, Boundary B is used, and the flows across the boundary to the utilities are each multiplied by their respective site-to-source multipliers.

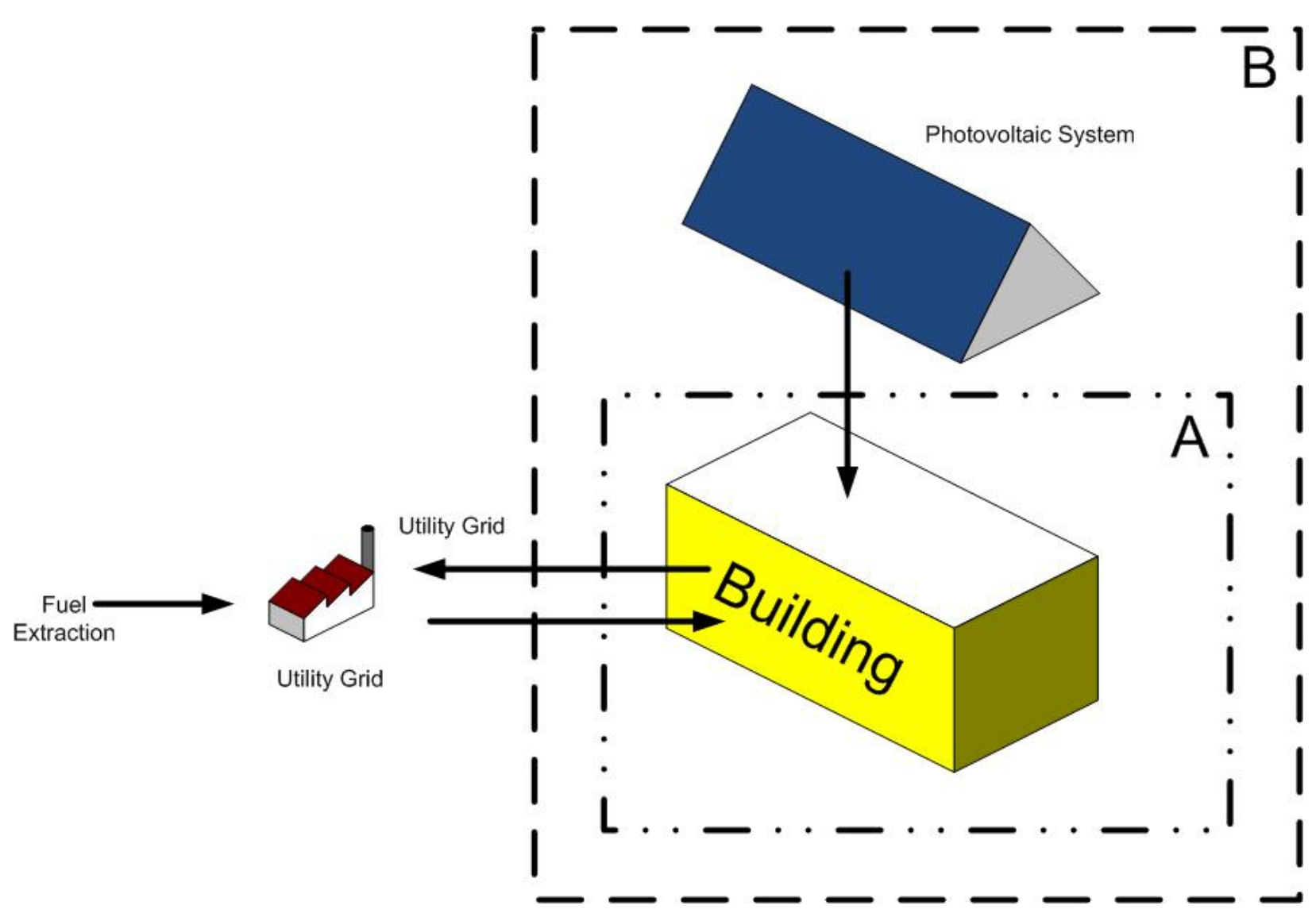

Figure 3. Schematic showing boundaries and energy flows for the building

Note that in the context of a ZEB, all loads — including lighting, HVAC, and plug loads — are considered, not only the loads that are regulated by codes (which may exclude plug loads). In this context, the building consumes energy, and that energy must be supplied by renewable energy resources on a source basis to meet the terms of the DOE definition.

\section{Modeling Methods}

EnergyPlus Version 8.4 (DOE 2015b) was used as the energy modeling engine, paired with OpenStudio (Guglielmetti, Macumber, and Long 2011) as the platform to manage input files, simulations, and results. EnergyPlus was selected because it is a tool that accounts for the complicated interactions among climate, internal gains, building form and materials, HVAC systems, and renewable energy systems. EnergyPlus is a heavily tested program with formal BESTEST validation efforts repeated for every release (Judkoff and Neymark 1995). OpenStudio's core functionality is the user's ability to include high-level parameters of the building (such as building area, internal gains per zone, and HVAC system configuration) to generate a fully parameterized EnergyPlus input file. Such files are generated rapidly and can be easily changed to accommodate the evolution of the model. The high-level parameter file is a flat text file. Modifying the high-level parameters is preferable to modifying the EnergyPlus input data file because it greatly simplifies the modeling input development process. Modifying 
EnergyPlus input files can be time intensive when the high-level parameters have a one-to-many relationship with the corresponding objects in the low-level input file.

Further, by performing the simulations in the OpenStudio environment, processes were developed to facilitate future applications to support the design and construction of ZEBs, particularly zero energy schools. This foundational work sets the stage for creating future tools for owners and design teams to design zero energy schools using the same analysis platform as this feasibility study.

The simulations were used to evaluate design parameters so that building energy consumption could be reduced as much as practically feasible with cost-effective applications of current technologies. The OpenStudio software took and "swept" two starting-point energy models (primary and secondary school) across the 15 cities representing the eight U.S. climate zones and corresponding subzones.

\section{Climate Zones}

This feasibility study contains a unique set of energy-efficiency strategies for each of the eight climate zones and three corresponding subzones in the United States (see Figure 4). The zones are defined primarily by heating degree days and cooling degree days (Briggs, Lucas, and Taylor 2003), and they range from very hot (Zone 1A) to extremely cold (Zone 8). Some are divided into subzones based on humidity levels. Humid subzones are "A" zones, dry subzones are "B" zones, and marine subzones are "C" zones. These climate zones may be mapped to other climate locations for international use, as in Appendix B of ASHRAE 2012. 


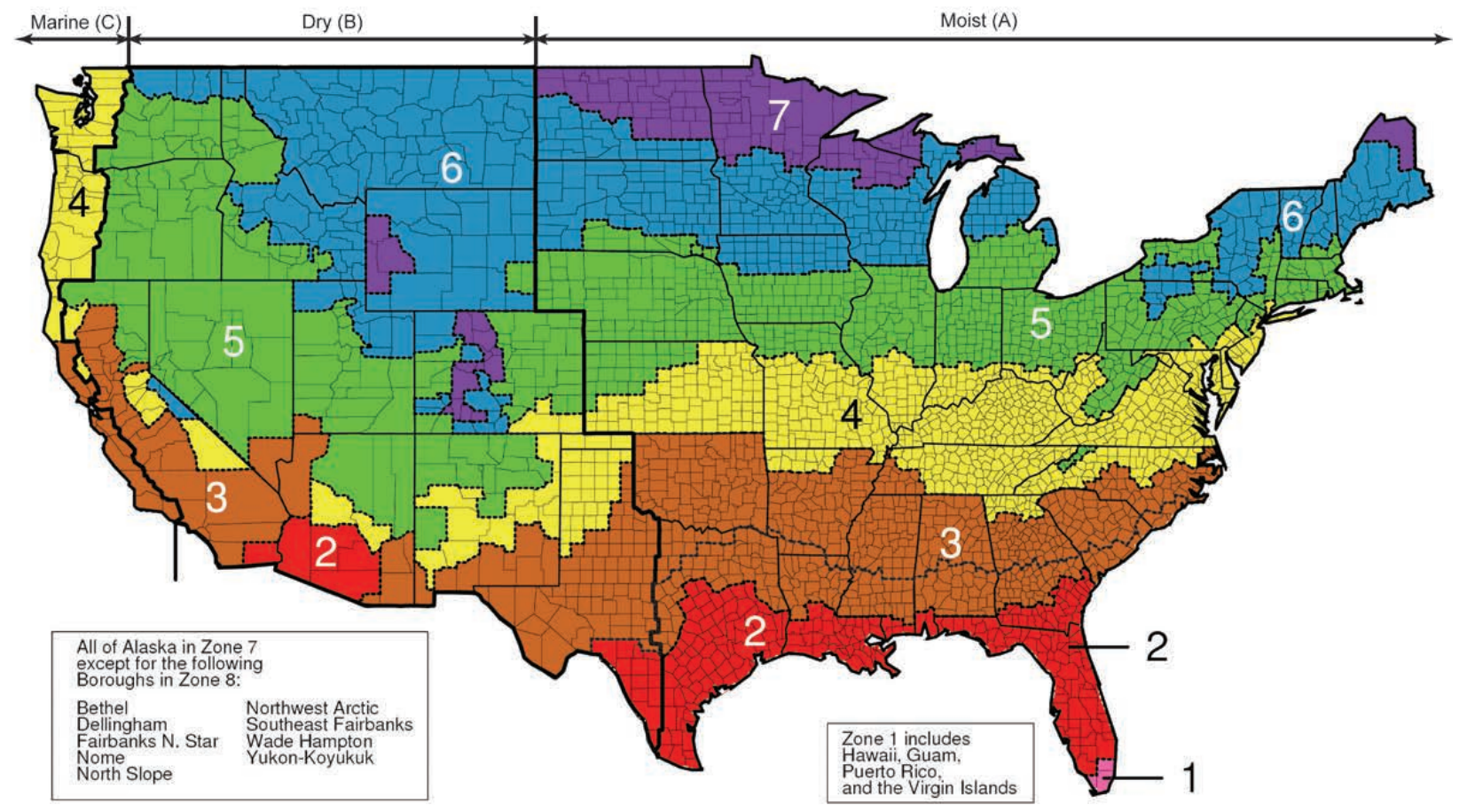

Figure 4. Climate zones and representative cities

(DOE 2003)

The 15 specific locations for which analyses were performed are listed below and are designated as being representative of their climate zones. Large cities were chosen because their weather data directly apply to a large fraction of the total U.S. building floor area. Energy consumption values were determined by running the energy model simulations with the Typical Meteorological Year 3 weather file.

- Zone 1A: Miami, Florida (very hot, humid)

- Zone 2A: Houston, Texas (hot, humid)

- Zone 2B: Phoenix, Arizona (hot, dry)

- Zone 3A: Memphis, Tennessee (hot, humid)

- Zone 3B: El Paso, Texas (hot, dry)

- Zone 3C: San Francisco, California (marine)

- Zone 4A: Baltimore, Maryland (mixed, humid)

- Zone 4B: Albuquerque, New Mexico (mixed, dry)

- Zone 4C: Salem, Oregon (marine)

- Zone 5A: Chicago, Illinois (cold, humid)

- Zone 5B: Boise, Idaho (cold, dry) 
- Zone 6A: Burlington, Vermont (cold, humid)

- Zone 6B: Helena, Montana (cold, dry)

- Zone 7: Duluth, Minnesota (very cold)

- Zone 8: Fairbanks, Alaska (extremely cold).

Unlike percent-savings energy analysis, ZEBs do not need a reference point to a fictitious codecompliant building as a mechanism to generate savings numbers. ZEBs rely on absolute numbers and balancing the absolute energy consumption with energy generated by renewables on-site. Although the comparison to existing buildings or current codes is not included in the analysis, the absolute targets provide a focused direction to minimize the energy impact of buildings such that they have a zero energy footprint.

\subsection{Model Overview}

Extensive modeling was used to determine the effectiveness of all the strategies considered in this feasibility study. This process was iterated until the final set of strategies was developed. This section documents energy models with the final set of feasibility study strategies.

Figure 5 shows a rendering of the primary school model, and Figure 6 shows a rendering of the secondary school model.

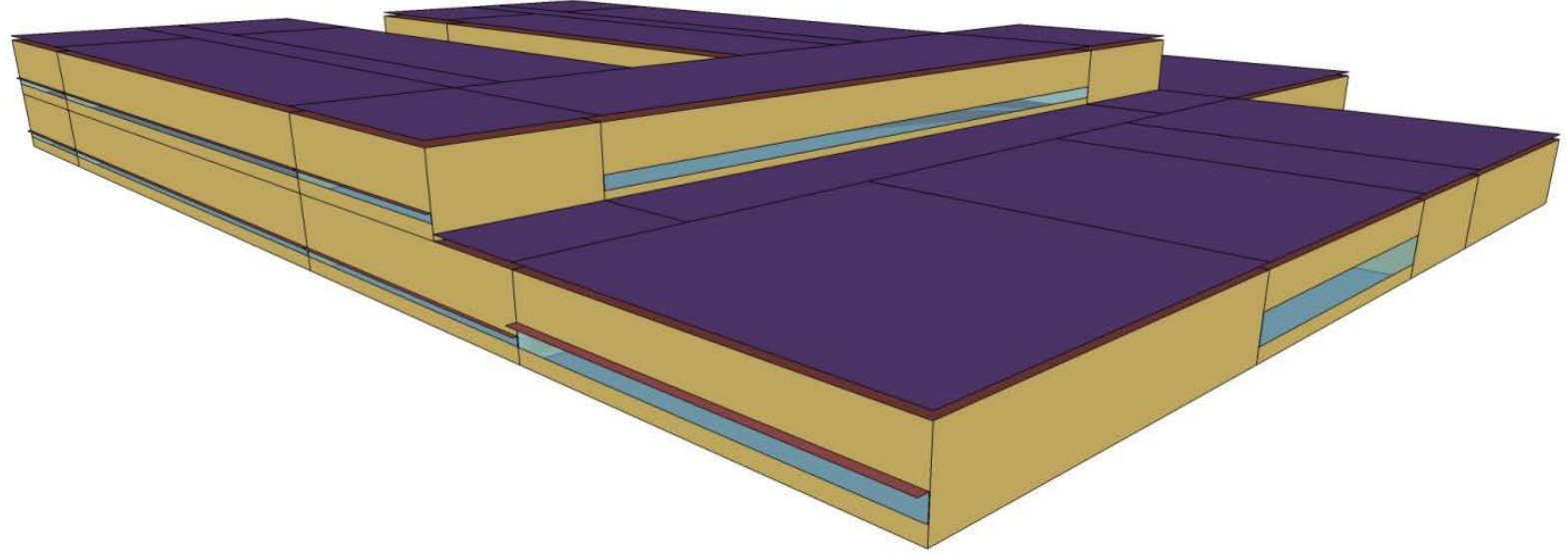

Figure 5. Primary school energy model rendering. Image from Eric Bonnema and David Goldwasser, NREL 


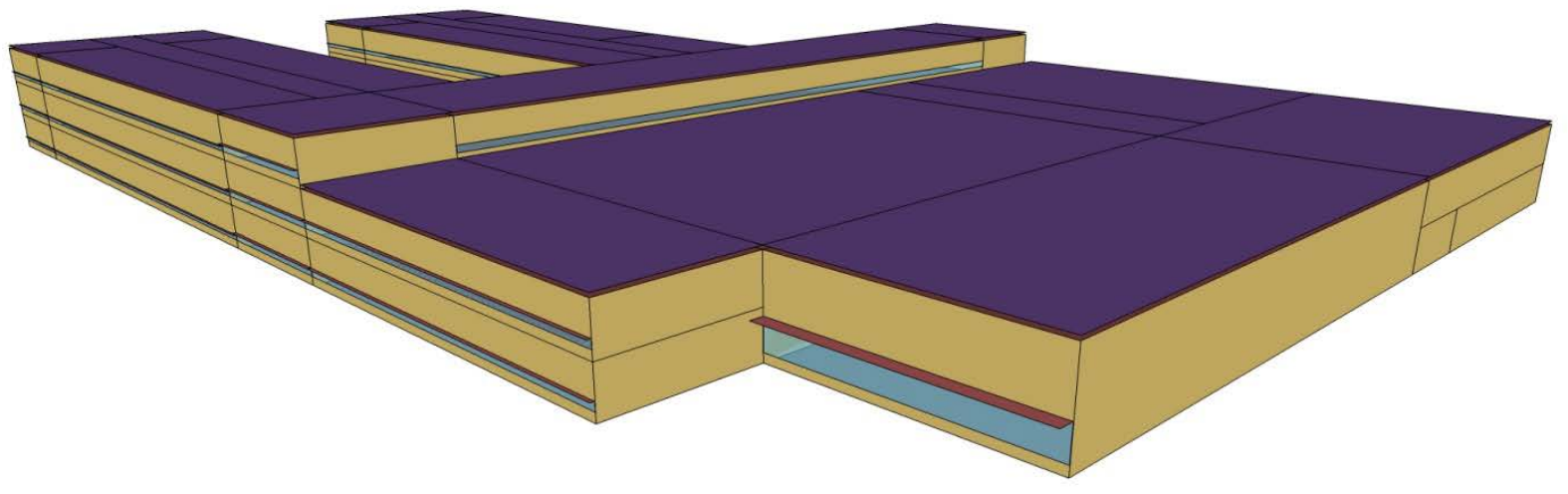

Figure 6. Secondary school energy model rendering.

Image from Eric Bonnema and David Goldwasser, NREL

A "typical" prototype model is an energy model that is a representative example of a typical $\mathrm{K}-$ 12 school facility. The primary and secondary school DOE Commercial Prototype Buildings Models (DOE 2014) were used as the "typical" prototypes for space layouts and space types. Because of different space (programmatic) requirements, a different model was used for primary schools and secondary schools. In many areas, middle schools are also used, but they typically fall between the primary and secondary schools in terms of space types. It is not necessary to model middle schools to determine their feasibility as zero energy schools as long as area primary and secondary schools can meet the ZEB criteria. The primary and secondary school DOE prototype building models (DOE 2014) were used as a starting point to help define building characteristics that were not regulated by code. The DOE prototype building models were derived from Deru et al. (2011), which based the primary and secondary school models mainly on Pless, Torcellini, and Long (2007).

The prototypical reference buildings were then modified to comply with the Advanced Energy Design Guide for K-12 School Buildings: Achieving 50\% Energy Savings toward a Net Zero Energy Building (ASHRAE 2012) and the related technical support document (Bonnema et al. 2013). These models were then compared to ASHRAE Standard 90.1-2013 (ASHRAE 2013b) to ensure that building parameters at least met the current code requirements. Next, space layouts were modified to represent current practice based on input from a technical advisor team assisting with the project. This team provided insights into current construction practices and industry changes since the 50\% Advanced Energy Design Guide for K-12 School Buildings was developed. The changes made at this stage included reducing the building footprint by increasing the number of stories. These changes made achieving ZEBs more challenging because the footprint decreased, reducing the amount of space available for renewable energy generation. The changes do, however, strengthen the feasibility case of achieving zero energy status for more schools and allow greater flexibility in design because of the increased building massing.

The space types in these models are shown in in Table 3. 
Table 3. Space Types

\begin{tabular}{lcc}
\hline Space Type & Primary School & Secondary School \\
\hline Auditorium & & $\mathrm{X}$ \\
Art classroom & $\mathrm{X}$ & $\mathrm{X}$ \\
Cafeteria & $\mathrm{X}$ & $\mathrm{X}$ \\
Classroom & $\mathrm{X}$ & $\mathrm{X}$ \\
Corridor & $\mathrm{X}$ & $\mathrm{X}$ \\
Gym & $\mathrm{X}$ & $\mathrm{X}$ \\
Kitchen & & $\mathrm{X}$ \\
Library & $\mathrm{X}$ & $\mathrm{X}$ \\
Lobby & $\mathrm{X}$ & $\mathrm{X}$ \\
Mechanical room & $\mathrm{X}$ & \\
Media center & $\mathrm{X}$ & $\mathrm{X}$ \\
Multipurpose room & $\mathrm{X}$ & $\mathrm{X}$ \\
Office & $\mathrm{X}$ & \\
Restroom & & \\
\hline
\end{tabular}

Table 4 presents a summary of the models.

Table 4. Model Summary

\begin{tabular}{lll}
\hline Characteristic & Primary School & Secondary School \\
\hline Size $\left(\mathrm{ft}^{2}\right)$ & 82,500 & 227,700 \\
Number of floors & 2 & 3 \\
Number of students & 650 & 1,200 \\
Window-to-wall ratio & $35 \%$ & $35 \%$ \\
Wall construction & Steel-framed & Steel-framed \\
Roof construction & Insulation entirely above deck & Insulation entirely above deck \\
\hline
\end{tabular}

\section{Geometry}

The primary school consists of approximately 82,500 square feet $\left(\mathrm{ft}^{2}\right)$ split between two floors. Classrooms account for the largest percentage of square footage among the different space types. Circulation space, administrative office space, and large flexible spaces (including a gymnasium) make up the balance.

The secondary school consists of approximately 227,700 $\mathrm{ft}^{2}$ split among three floors. Secondary schools are more complex programmatically, they are significantly larger, and classrooms account for the largest percentage among the space types. Because of special space requirements, however, secondary school classrooms take up less space on a percentage basis compared to primary school classrooms, and more space is dedicated to special-function areas such as a gymnasium, auditorium, kitchen, and cafeteria as well as additional administrative office spaces.

Table 5, Figure 7, and Figure 8 provide a breakdown of the prototype models by space type. 
Table 5. Space Type Breakdown

\begin{tabular}{ccccc}
\hline \multirow{2}{*}{ Space Type } & \multicolumn{2}{c}{ Primary School } & \multicolumn{2}{c}{ Secondary School } \\
\cline { 2 - 5 } & $\begin{array}{c}\text { Area } \\
\mathbf{( f t}^{\mathbf{2}}\end{array}$ & $\begin{array}{c}\text { Percentage of } \\
\text { Total }\end{array}$ & $\begin{array}{c}\text { Area } \\
\left.\mathbf{f f t}^{2}\right)\end{array}$ & $\begin{array}{c}\text { Percentage of } \\
\text { Total }\end{array}$ \\
\hline Auditorium & 0 & $0 \%$ & 10,634 & $5 \%$ \\
Art classroom & 1,744 & $2 \%$ & 1,744 & $1 \%$ \\
Cafeteria & 3,391 & $4 \%$ & 6,717 & $3 \%$ \\
Classroom & 35,464 & $43 \%$ & 72,668 & $32 \%$ \\
Corridor & 17,954 & $22 \%$ & 57,474 & $25 \%$ \\
Gym/multipurpose room & 3,843 & $5 \%$ & 34,702 & $15 \%$ \\
Kitchen & 1,808 & $2 \%$ & 2,325 & $1 \%$ \\
Library/media center & 4,295 & $5 \%$ & 9,042 & $4 \%$ \\
Lobby & 3,100 & $4 \%$ & 6,780 & $3 \%$ \\
Mechanical room & 2,713 & $3 \%$ & 7,364 & $3 \%$ \\
Office & 4,747 & $6 \%$ & 11,452 & $5 \%$ \\
Restroom & 3,444 & $4 \%$ & 6,780 & $3 \%$ \\
Total & 82,503 & $100 \%$ & 227,682 & $100 \%$ \\
\hline
\end{tabular}

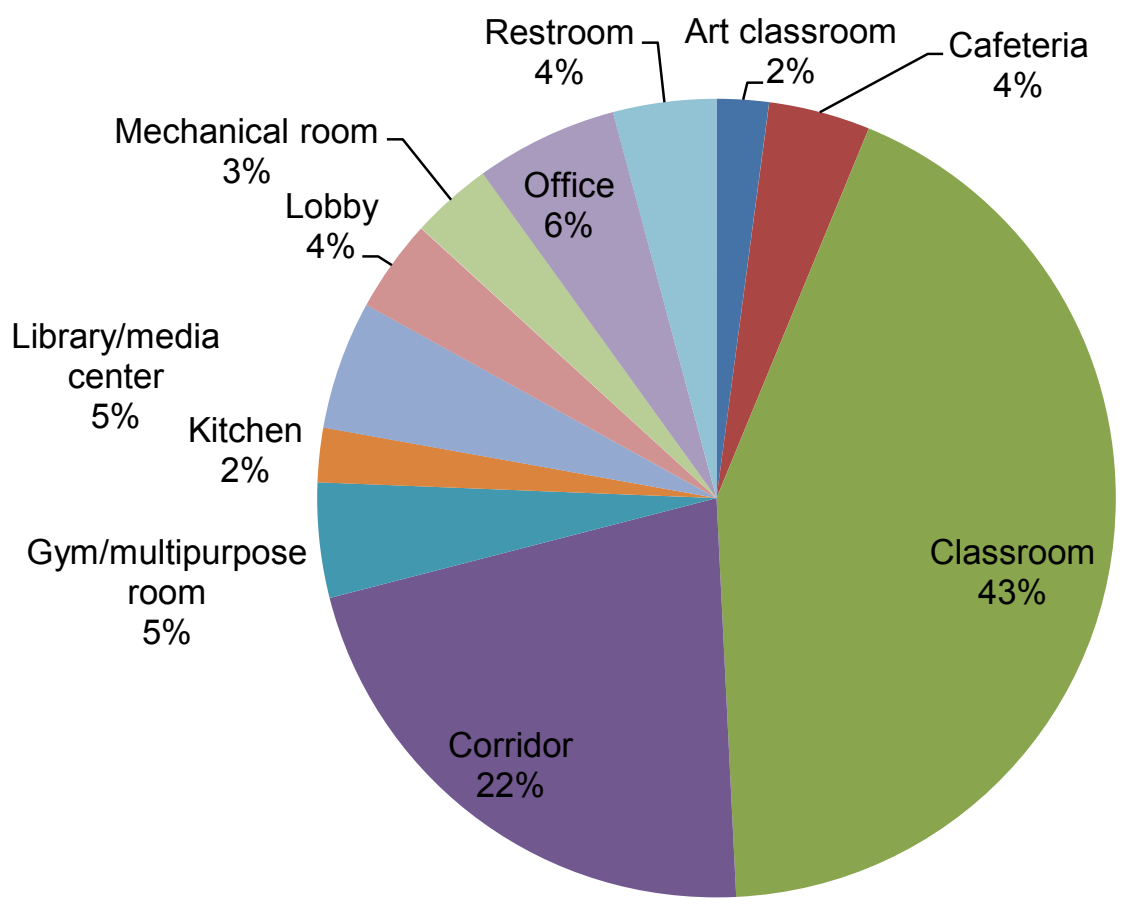

Figure 7. Space type breakdown-primary school 


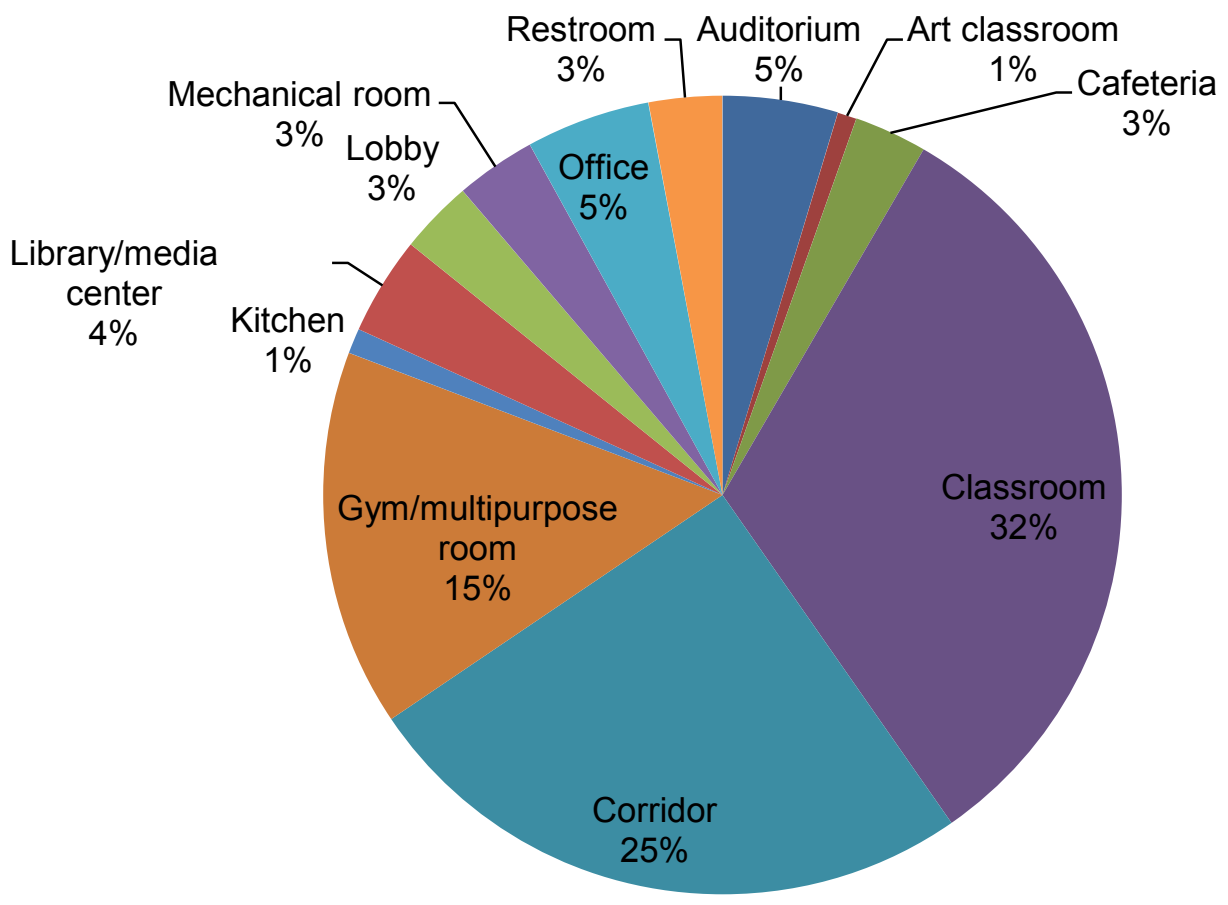

Figure 8. Space type breakdown-secondary school

Table 6 and Table 7 also map each zone to a space type. These space types are referenced throughout the rest of this feasibility study when describing other model inputs (such as lighting and plug loads). This information was translated to floor plans as shown in Figure 9, Figure 10, Figure 11, Figure 12, and Figure 13. 
Table 6. Primary School Zone Geometry Breakdown

\begin{tabular}{|c|c|c|c|c|c|}
\hline Zone Type & Space Type & Qty. & $\begin{array}{l}\text { Dimensions } \\
(\mathrm{ft} \times \mathrm{ft})\end{array}$ & $\begin{array}{c}\text { Zone } \\
\text { Area } \\
\left(\mathrm{ft}^{2}\right)\end{array}$ & $\begin{array}{c}\text { Total } \\
\text { Area } \\
\left(\mathrm{ft}^{2}\right)\end{array}$ \\
\hline $\begin{array}{l}\text { Corner } \\
\text { classroom }\end{array}$ & Classroom & $\begin{array}{l}\text { 4-first floor } \\
\text { 4-second } \\
\text { floor }\end{array}$ & $36.1 \times 29.5$ & 1,066 & 8,528 \\
\hline $\begin{array}{l}\text { Large classroom } \\
\text { group }\end{array}$ & Classroom & $\begin{array}{l}\text { 3-first floor } \\
\text { 4-second } \\
\text { floor }\end{array}$ & $121.4 \times 29.5$ & 3,585 & 25,095 \\
\hline $\begin{array}{l}\text { Small classroom } \\
\text { group }\end{array}$ & Classroom & 1-first floor & $62.4 \times 29.5$ & 1,841 & 1,841 \\
\hline Art classroom & Art room & 1-first floor & $59.1 \times 29.5$ & 1,744 & 1,744 \\
\hline $\begin{array}{l}\text { Classroom } \\
\text { corridors }\end{array}$ & Corridor & $\begin{array}{l}\text { 2-first floor } \\
\text { 2-second } \\
\text { floor }\end{array}$ & $157.5 \times 9.8$ & 1,550 & 6,200 \\
\hline $\begin{array}{l}\text { Ground floor } \\
\text { lobby }\end{array}$ & Lobby & 1-first floor & $62.3 \times 29.5$ & 1,841 & 1,841 \\
\hline Upper floor lobby & Lobby & $\begin{array}{l}\text { 1-second } \\
\text { floor }\end{array}$ & $42.7 \times 29.5$ & 1,259 & 1,259 \\
\hline Main corridor & Corridor & $\begin{array}{l}\text { 1-first floor } \\
1 \text {-second } \\
\text { floor }\end{array}$ & $42.7 \times 137.8$ & 5,877 & 11,754 \\
\hline Mechanical room & Mechanical & 1-first floor & $19.7 \times 137.8$ & 2,713 & 2,713 \\
\hline $\begin{array}{l}\text { First-floor } \\
\text { restrooms }\end{array}$ & Restroom & 1-first floor & $62.34 \times 32.8$ & 2,045 & 2,045 \\
\hline $\begin{array}{l}\text { Second-floor } \\
\text { restrooms }\end{array}$ & Restroom & 1-first floor & $42.7 \times 32.8$ & 1,399 & 1,399 \\
\hline Media center & $\begin{array}{l}\text { Library/media } \\
\text { center }\end{array}$ & 1-first floor & $62.3 \times 68.9$ & 4,295 & 4,295 \\
\hline Offices & Office & 1-first floor & $68.9 \times 68.9$ & 4,747 & 4,747 \\
\hline $\begin{array}{l}\text { Multipurpose } \\
\text { room }\end{array}$ & $\begin{array}{l}\text { Gym/multipurpose } \\
\text { room }\end{array}$ & 1-first floor & $68.9 \times 55.8$ & 3,843 & 3,843 \\
\hline Kitchen & Kitchen & 1-first floor & $68.9 \times 26.3$ & 1,808 & 1,808 \\
\hline Cafeteria & Cafeteria & 1-first floor & $68.9 \times 49.2$ & 3,391 & 3,391 \\
\hline Total & & & & & 82,503 \\
\hline
\end{tabular}


Table 7. Secondary School Zone Geometry Breakdown

\begin{tabular}{|c|c|c|c|c|c|}
\hline Zone Type & Space Type & Quantity & $\begin{array}{l}\text { Dimensions } \\
(\mathrm{ft} \times \mathrm{ft})\end{array}$ & $\begin{array}{c}\text { Zone } \\
\text { Area } \\
\left(\mathrm{ft}^{2}\right)\end{array}$ & $\begin{array}{c}\text { Total } \\
\text { Area } \\
\left(\mathrm{ft}^{2}\right)\end{array}$ \\
\hline $\begin{array}{l}\text { Corner } \\
\text { classroom }\end{array}$ & Classroom & $\begin{array}{l}\text { 4-first floor } \\
\text { 4-second floor } \\
\text { 4-third floor }\end{array}$ & $36.1 \times 29.5$ & 1,066 & 12,792 \\
\hline $\begin{array}{l}\text { Large } \\
\text { classroom } \\
\text { group }\end{array}$ & Classroom & $\begin{array}{l}\text { 4-first floor } \\
\text { 4-second floor } \\
\text { 3-third floor }\end{array}$ & $173.9 \times 29.5$ & 5,135 & 56,485 \\
\hline $\begin{array}{l}\text { Small } \\
\text { classroom } \\
\text { group }\end{array}$ & Classroom & 1-third floor & $114.8 \times 29.5$ & 3,391 & 3,391 \\
\hline Art classroom & Art room & 1-third floor & $59.1 \times 29.5$ & 1,744 & 1,744 \\
\hline $\begin{array}{l}\text { Classroom } \\
\text { corridors }\end{array}$ & Corridor & $\begin{array}{l}\text { 2-first floor } \\
\text { 2-second floor } \\
\text { 2-third floor }\end{array}$ & $210.0 \times 16.4$ & 3,444 & 20,664 \\
\hline Lobby & Lobby & $\begin{array}{l}\text { 1-first floor } \\
\text { 1-second floor } \\
\text { 1-third floor }\end{array}$ & $49.2 \times 45.9$ & 2,260 & 6,780 \\
\hline Main corridor & Corridor & $\begin{array}{l}\text { 1-first floor } \\
\text { 1-second floor }\end{array}$ & $49.2 \times 249.3$ & 12,270 & 36,810 \\
\hline $\begin{array}{l}\text { Mechanical } \\
\text { room }\end{array}$ & Mechanical & $\begin{array}{l}\text { 1-first floor } \\
\text { 1-second floor }\end{array}$ & $124.7 \times 29.6$ & 3,682 & 7,364 \\
\hline Restrooms & Restroom & $\begin{array}{l}\text { 1-first floor } \\
\text { 1-second floor } \\
\text { 1-third floor }\end{array}$ & $49.2 \times 45.9$ & 2,260 & 6,780 \\
\hline Library & $\begin{array}{l}\text { Library/media } \\
\text { center }\end{array}$ & 1-second floor & $78.7 \times 114.8$ & 9,042 & 9,042 \\
\hline Offices & Office & $\begin{array}{l}\text { 1-first floor } \\
\text { 1-second floor }\end{array}$ & $124.7 \times 45.9$ & 5,726 & 11,452 \\
\hline Gym & $\begin{array}{l}\text { Gym/multipurpose } \\
\text { room }\end{array}$ & 1-first floor & $\begin{array}{l}124.7 \times \\
170.6\end{array}$ & 21,269 & 21,269 \\
\hline Kitchen & Kitchen & 1-first floor & $78.7 \times 29.5$ & 2,325 & 2,325 \\
\hline Cafeteria & Cafeteria & 1-first floor & $78.7 \times 85.3$ & 6,717 & 6,717 \\
\hline Auditorium & Auditorium & 1-first floor & $124.7 \times 85.3$ & 10,634 & 10,634 \\
\hline Auxiliary gym & $\begin{array}{l}\text { Gym/multipurpose } \\
\text { room }\end{array}$ & 1-first floor & $78.7 \times 170.6$ & 13,433 & 13,433 \\
\hline Total & & & & & 227,682 \\
\hline
\end{tabular}




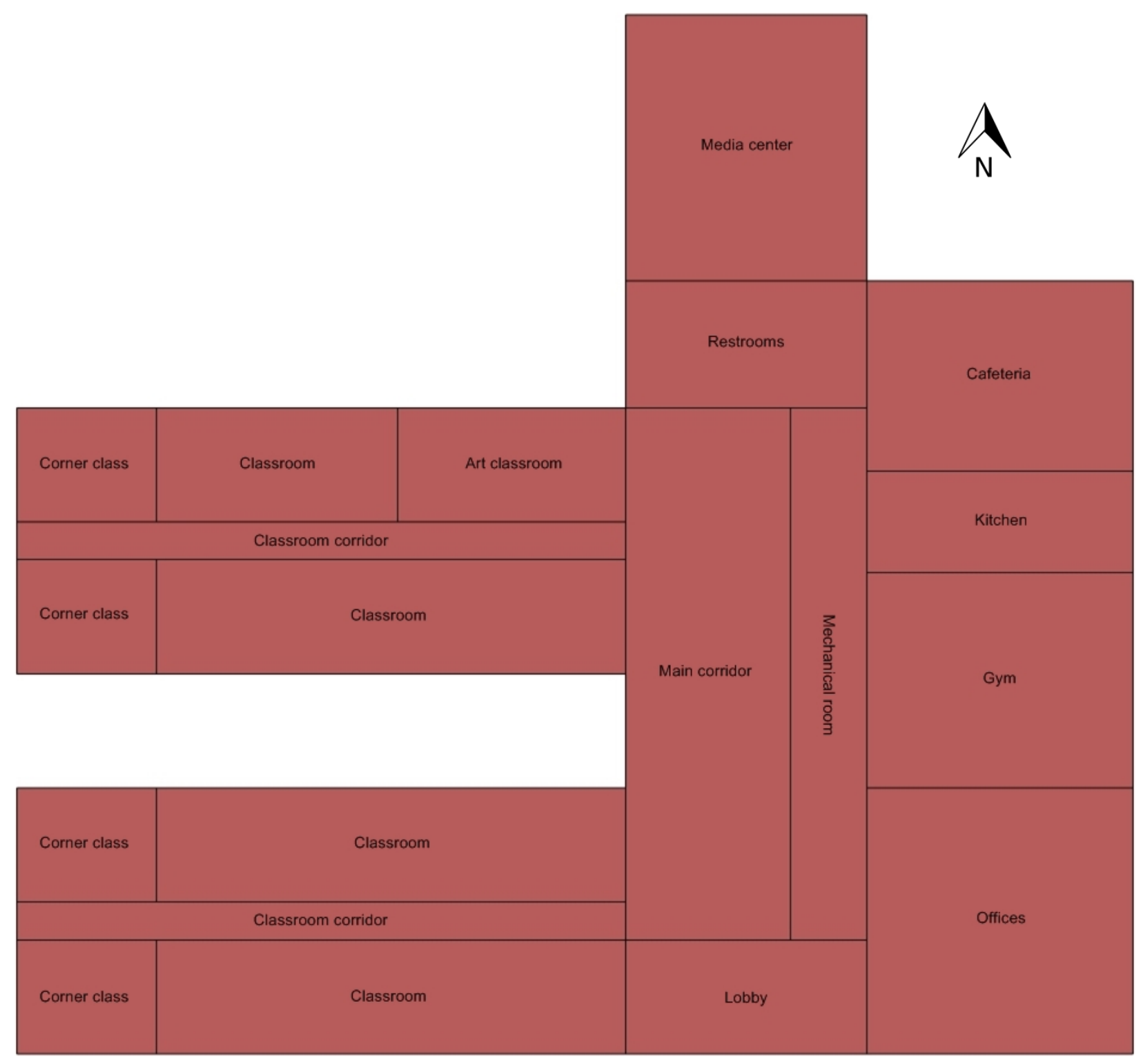

Figure 9. Primary school zone layout-first floor 


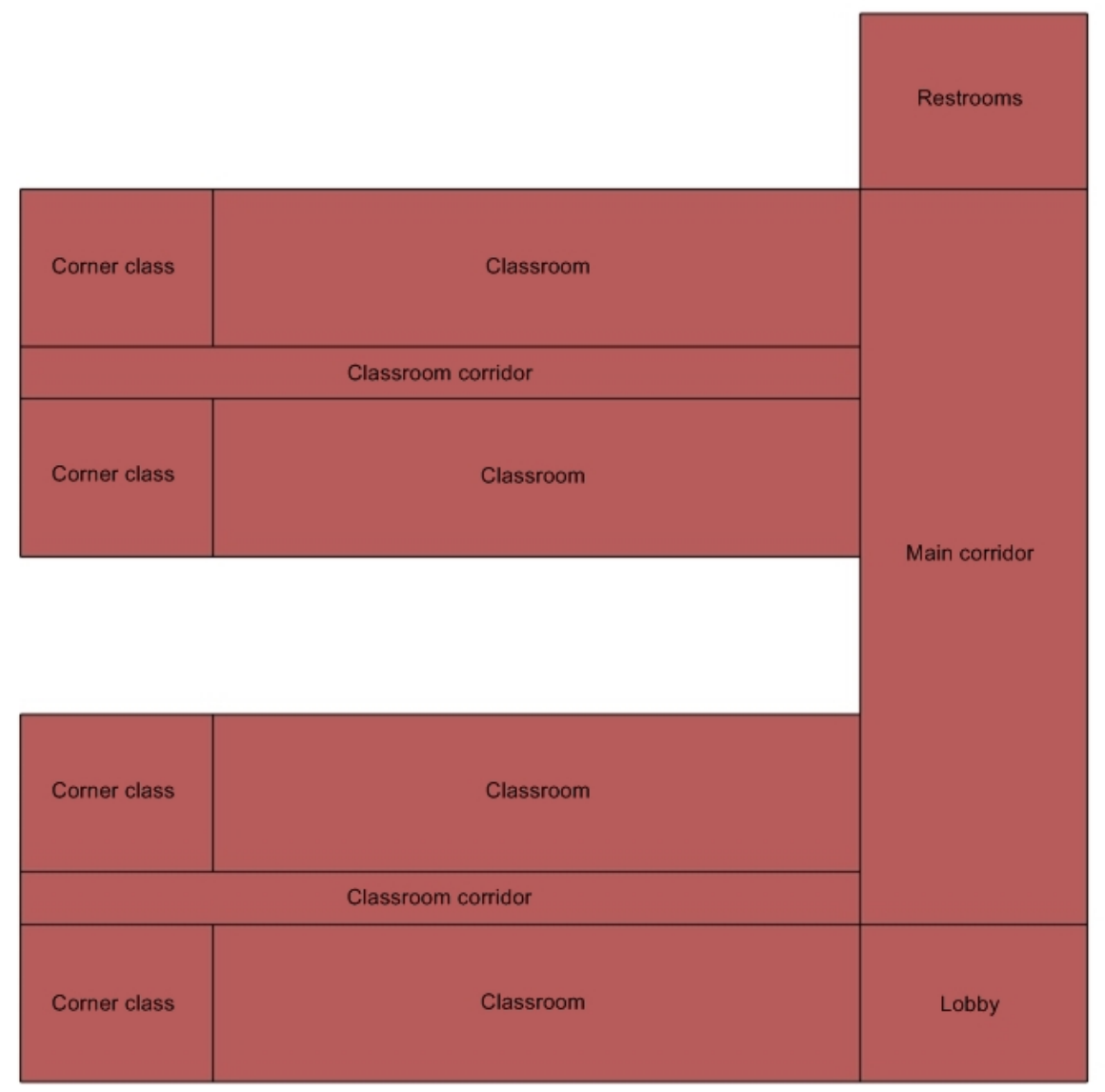

A

Figure 10. Primary school zone layout-second floor 


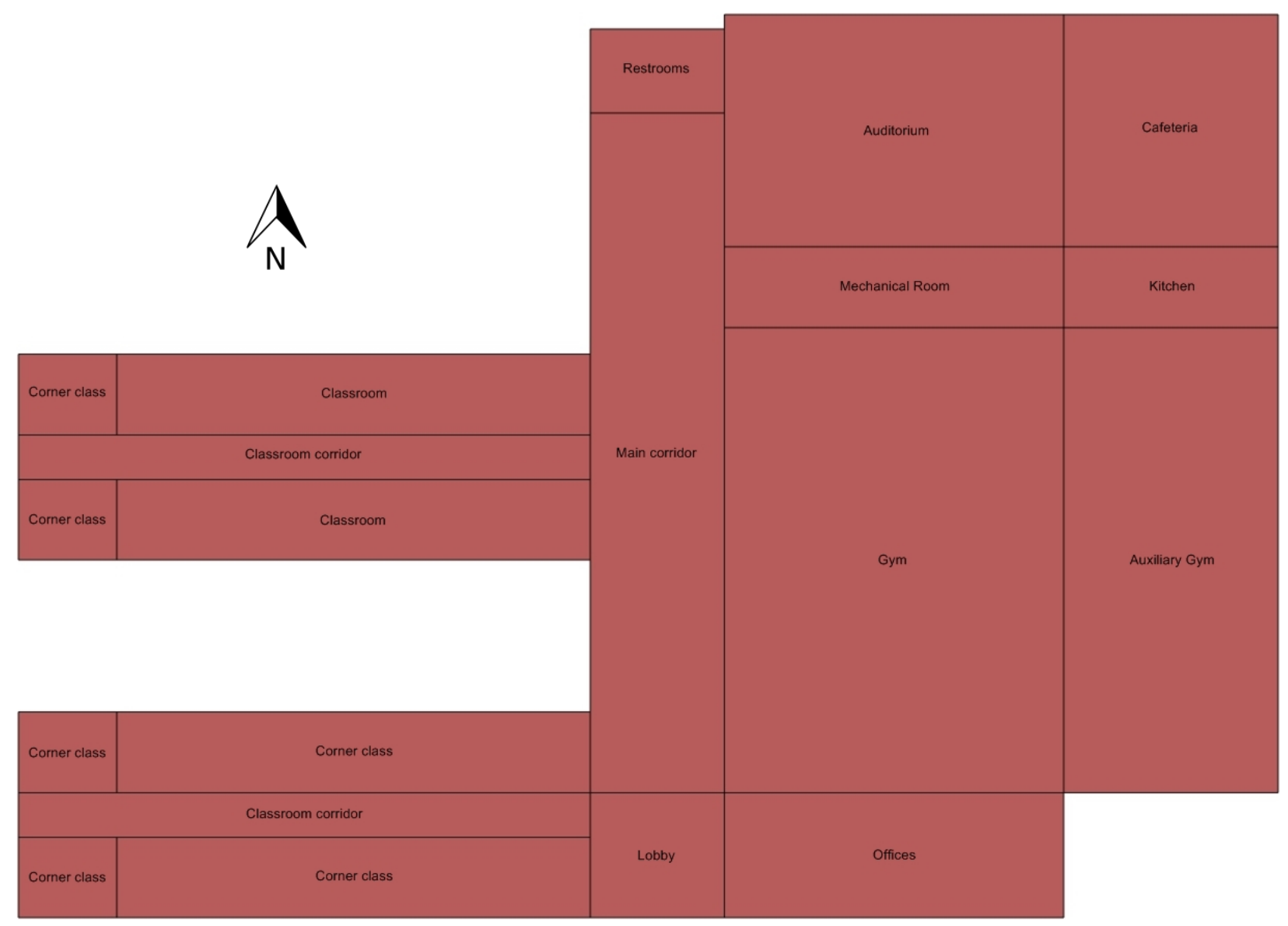

Figure 11. Secondary school zone layout-first floor 


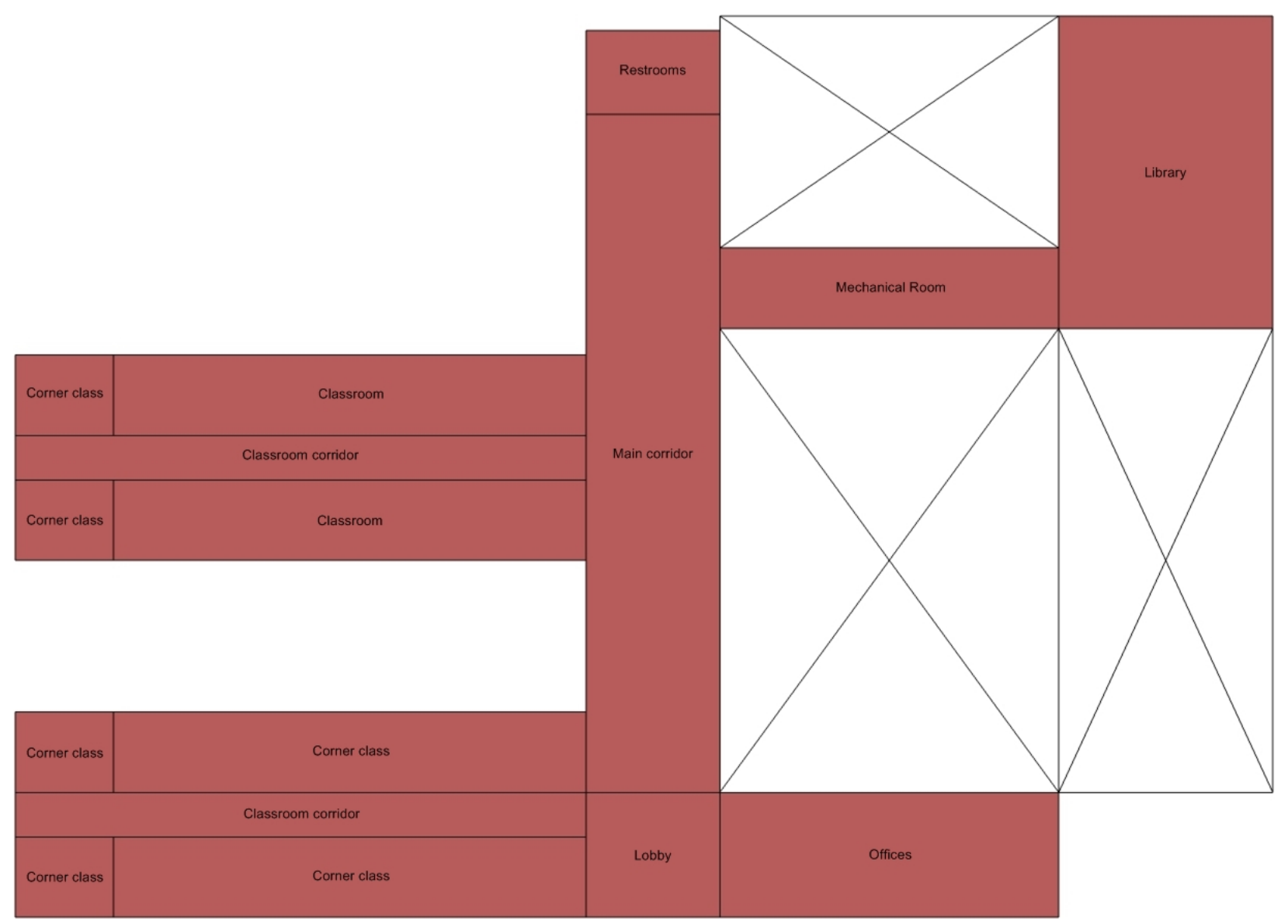

Figure 12. Secondary school zone layout-second floor 


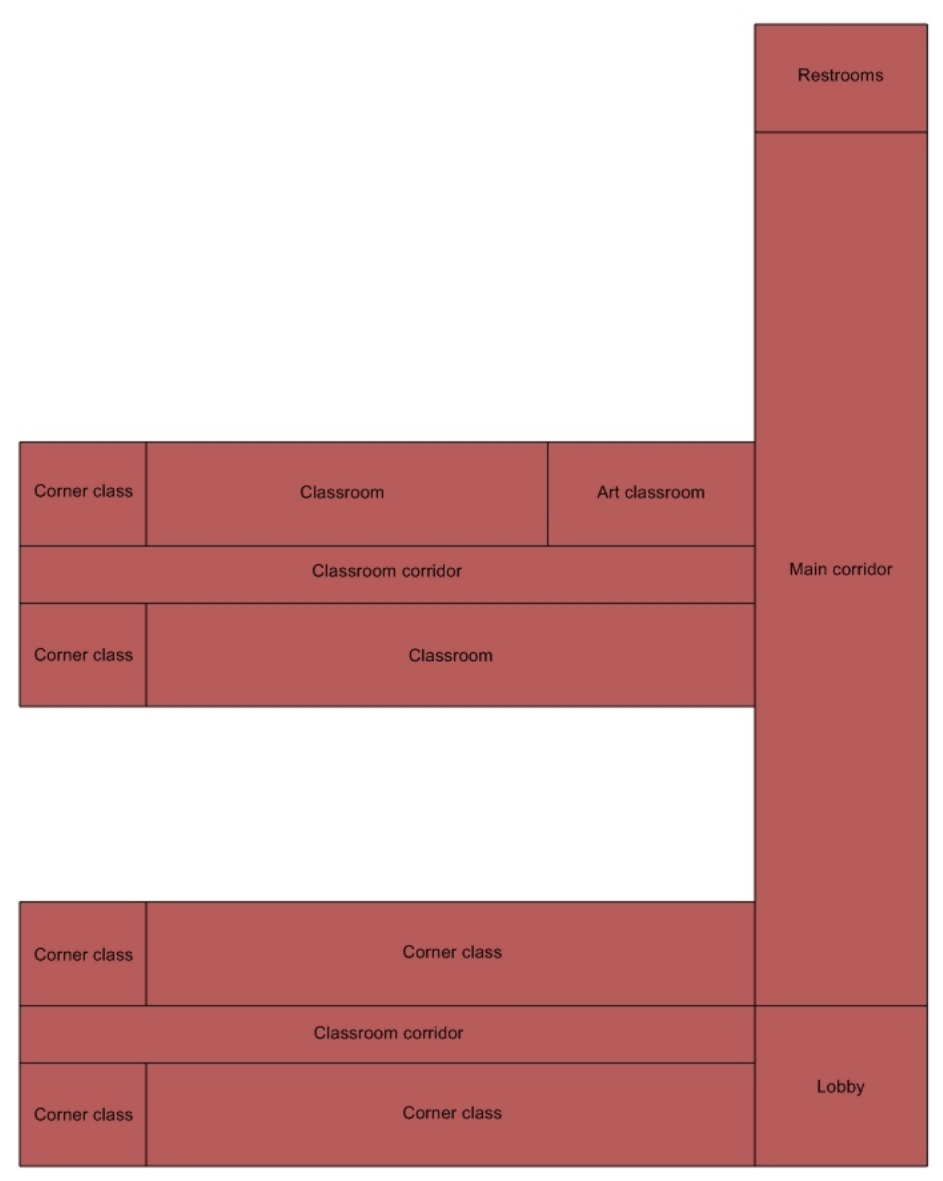

Figure 13. Secondary school zone layout-third floor

\section{Envelope}

Based on the experiences of those in the $\mathrm{K}-12$ school construction industry, it was assumed that these facilities are typically constructed with steel-framed exterior walls, built-up roofs, and slabon-grade floors. These construction strategies represent common practices. There are some regional variations, but steel-framed walls and built-up roofs were the most common techniques.

Layer-by-layer descriptions of the construction methods and materials were used to model the building thermal envelope in EnergyPlus.

\section{Exterior Walls}

The schools were modeled with steel-framed wall construction. The layers consisted of exterior sheathing, insulation, and gypsum board. The exterior wall R-values and U-values are shown in Table 8 . 
Table 8. Exterior Wall Constructions

\begin{tabular}{|c|c|c|}
\hline $\begin{array}{l}\text { Climate } \\
\text { Zone }\end{array}$ & $\begin{array}{l}\text { Assembly U-Factor } \\
\left(\mathrm{Btu} / \mathrm{h} \cdot \mathrm{ft}^{2} \cdot{ }^{\circ} \mathrm{F}\right)\end{array}$ & $\begin{array}{c}\text { Insulation R-Value, Nominal } \\
\left(\mathrm{h} \cdot \mathrm{ft}^{2 .}{ }^{\circ} \mathrm{F} / \mathrm{Btu}\right)\end{array}$ \\
\hline 1 & U-0.064 & R-13.0 + R-7.5 c.i. ${ }^{a}$ \\
\hline 2 & U-0.064 & R-13.0 + R-7.5 c.i. \\
\hline 3 & U-0.064 & R-13.0 + R-7.5 c.i. \\
\hline 4 & U-0.064 & R-13.0 + R-7.5 c.i. \\
\hline 5 & U-0.042 & R-13.0 + R-15.6 c.i. \\
\hline 6 & U-0.037 & R-13.0 + R-18.8 c.i. \\
\hline 7 & U-0.037 & R-13.0 + R-18.8 c.i. \\
\hline 8 & U-0.037 & R-13.0 + R-18.8 c.i. \\
\hline
\end{tabular}

The steel-framed wall includes the following layers:

- Exterior air film (calculated by EnergyPlus)

- Exterior sheathing

- Insulation (R-value varies by climate)

- 0.5 -in.-thick gypsum board

- Interior air film (calculated by EnergyPlus).

To calculate the thermal performance of the interior air films, the "TARP" algorithm in EnergyPlus for surface heat transfer film coefficients was used; and to calculate the thermal performance of the exterior air films, the "DOE-2" algorithm in EnergyPlus for surface heat transfer film coefficients was used. These are based on linearized radiation coefficients that are separate from the convection coefficients as determined by surface roughness, wind speed, and terrain. However, standardized combined film coefficients were used to target assembly Ufactors; these coefficients can be found in DOE (2015b) as shown in Table 9.

Table 9. Standard Film Coefficients

\begin{tabular}{lcc}
\hline Surface Class & $\begin{array}{c}\text { Interior Film Coefficient } \\
\left(\mathbf{h} \cdot \mathbf{f t}^{2} \cdot{ }^{\circ} \mathrm{F} / \mathrm{Btu}\right)\end{array}$ & $\begin{array}{c}\text { Exterior Film Coefficient } \\
\left(\mathbf{h} \cdot \mathbf{f t}^{\mathbf{2}}{ }^{\circ} \mathrm{F} / \mathrm{Btu}\right)\end{array}$ \\
\hline Wall & 0.68 & 0.17 \\
Floor & 0.92 & 0.46 \\
Ceiling/roof & 0.61 & 0.46 \\
\hline
\end{tabular}

\section{Roofs}

Built-up, rigid insulation above a structural metal deck roof was used in the models. The layers consisted of the roof membrane, roof insulation, and metal decking. The U-factors varied based on the applicable climate zone. Added insulation was continuous and uninterrupted by framing. The roof R-values and U-values are provided in Table 10. 
Table 10. Roof Constructions

\begin{tabular}{|c|c|c|}
\hline $\begin{array}{l}\text { Climate } \\
\text { Zone }\end{array}$ & $\begin{array}{l}\text { Assembly U-Factor } \\
\left(\mathrm{Btu} / \mathrm{h} \cdot \mathrm{ft}^{2} \cdot{ }^{\circ} \mathrm{F}\right)\end{array}$ & $\begin{array}{c}\text { Insulation R-Value, Nominal } \\
\left(\mathrm{h} \cdot \mathrm{ft}^{2 .}{ }^{\circ} \mathrm{F} / \mathrm{Btu}\right)\end{array}$ \\
\hline 1 & U-0.048 & R-20.0 c.i. \\
\hline 2 & U-0.039 & R-25.0 c.i. \\
\hline 3 & U-0.039 & R-25.0 c.i. \\
\hline 4 & U-0.032 & R-30.0 c.i. \\
\hline 5 & U-0.032 & R-30.0 c.i. \\
\hline 6 & U-0.032 & R-30.0 c.i. \\
\hline 7 & U-0.028 & R-35.0 c.i. \\
\hline 8 & U-0.028 & R-35.0 c.i. \\
\hline
\end{tabular}

The roof exterior finish in the models was assumed to be a single-ply gray ethylene propylene polymer roof membrane; therefore, we assumed a solar reflectance of 0.3 , a thermal absorption of 0.9 , and a visible absorption of 0.7 .

\section{Slab-on-Grade Floors}

The buildings were modeled with slab-on-grade floors, which consisted of a carpet and pad layer over an 8-in.-thick heavyweight concrete layer.

The ground-coupled heat transfer of the slab was modeled using the integrated site ground domain model within EnergyPlus. The ground domain depth was assumed to be 5 meters (m), the aspect ratio was set to 1 , and the perimeter offset was $5 \mathrm{~m}$. The soil properties for the site ground domain model are shown in Table 11.

Table 11. Soil Properties

\begin{tabular}{lr}
\hline Soil Property & Value \\
\hline Thermal conductivity $(\mathrm{W} / \mathrm{m} \cdot \mathrm{K})$ & 1.8 \\
Density $\left(\mathrm{kg} / \mathrm{m}^{3}\right)$ & 3,200 \\
Specific heat $(\mathrm{J} / \mathrm{kg} \cdot \mathrm{K})$ & 836 \\
Moisture content volume fraction & $30 \%$ \\
Moisture content volume fraction at saturation & $50 \%$ \\
\hline
\end{tabular}

The Kusuda-Achenbach undisturbed ground temperature model was used, with soil properties from Table 11. The average soil surface temperature, average amplitude of surface temperature, and phase shift of minimum surface temperature needed for the Kusuda-Achenbach undisturbed ground temperature model are calculated for each climate zone using the CalcSoilSurfTemp program that is packaged with EnergyPlus along with the EnergyPlus weather file for each climate location. In climate zones 6,7 , and 8 , this feasibility study recommends vertical slab insulation. See Section 4.1 for more details. 


\section{Fenestration}

Building fenestration includes all envelope penetrations used for ingress and egress or lighting such as windows, doors, and skylights.

This feasibility study specifies window properties as window systems and not as window frame and glass separately; thus, window frames were not explicitly modeled, and only one window was modeled per exterior surface. This reduced the complexity and increased the speed of the EnergyPlus simulations. Most of the building (except the restrooms, gym, and auditorium [secondary school only]) had an overall fraction of fenestration to gross wall area of $35 \%$; individual fenestration objects were distributed evenly on applicable exterior surfaces.

The U-factors and solar heat gain coefficients (SHGCs) that were applied to the fenestration objects were whole-assembly values and included framing effects. The U-factors, SHGCs, and visible light transmittance (VLT) of the windows that were used in both the primary and secondary school zero energy models are shown in Table 12.

Table 12. Window Constructions

\begin{tabular}{lccc}
\hline $\begin{array}{l}\text { Climate } \\
\text { Zone }\end{array}$ & $\begin{array}{c}\text { U-Factor } \\
\left(\mathbf{B t u}^{\prime} \cdot \mathbf{f t}^{2} \cdot{ }^{\circ} \mathrm{F}\right)\end{array}$ & SHGC & VLT \\
\hline $1(\mathrm{~A}, \mathrm{~B})$ & 1.22 & 0.25 & 0.280 \\
$2(\mathrm{~A}, \mathrm{~B})$ & 1.22 & 0.25 & 0.280 \\
$3(\mathrm{~A}, \mathrm{~B})$ & 0.57 & 0.25 & 0.280 \\
$3(\mathrm{C})$ & 1.22 & 0.25 & 0.280 \\
$4(\mathrm{~A}, \mathrm{~B}, \mathrm{C})$ & 0.57 & 0.26 & 0.290 \\
$5(\mathrm{~A}, \mathrm{~B})$ & 0.57 & 0.26 & 0.290 \\
$6(\mathrm{~A}, \mathrm{~B})$ & 0.57 & 0.35 & 0.390 \\
7 & 0.57 & 0.40 & 0.440 \\
8 & 0.46 & 0.40 & 0.440 \\
\hline
\end{tabular}

\section{Infiltration}

Infiltration is the flow of outdoor air into a building through cracks and other unintentional openings and through the normal use of exterior doors for ingress and egress. Infiltration is also known as air leakage into a building (ASHRAE 2009).

Infiltration rates were calculated using an infiltration rate factor and total exterior wall areas for each zone. The calculated infiltration rate factor was assumed to be constant throughout the year. This is a good assumption for annual energy performance, but caution should be used when evaluating hourly loads with this method.

To determine the infiltration rate factor, the building was assumed to be constructed such that at a pressure differential of 75 Pascals $(\mathrm{Pa})$, the infiltration rate was equivalent to 0.25 cubic feet per minute $(\mathrm{CFM}) / \mathrm{ft}^{2}$ of external wall area. Using a flow coefficient of 0.65 and an assumed pressure differential across the envelope of $4 \mathrm{~Pa}$ (a pressure likely to be encountered during normal building operation), the final infiltration rate factor of $0.037 \mathrm{CFM} / \mathrm{ft}^{2}$ was calculated. For 
zones with no external wall surfaces, the infiltration rate was set to zero. This methodology is consistent with that used by Deru et al. (2011).

Because a large amount of outdoor air was brought into the building by the HVAC system, the calculated zone infiltration rates were modified via an infiltration schedule that was set to 0.5 during HVAC system operation. The infiltration schedule was a simple multiplier that in this case reduced the total infiltration by half. When the HVAC system was shut off for unoccupied periods, this schedule was changed to 1 to simulate the greater infiltration rate that would result from the building no longer being pressurized. A different infiltration schedule was applied to the gym (and the auditorium in the secondary school) for the extended hours this space would be occupied. The infiltration schedules are shown in Figure 14 (primary school) and Figure 15 (secondary school).

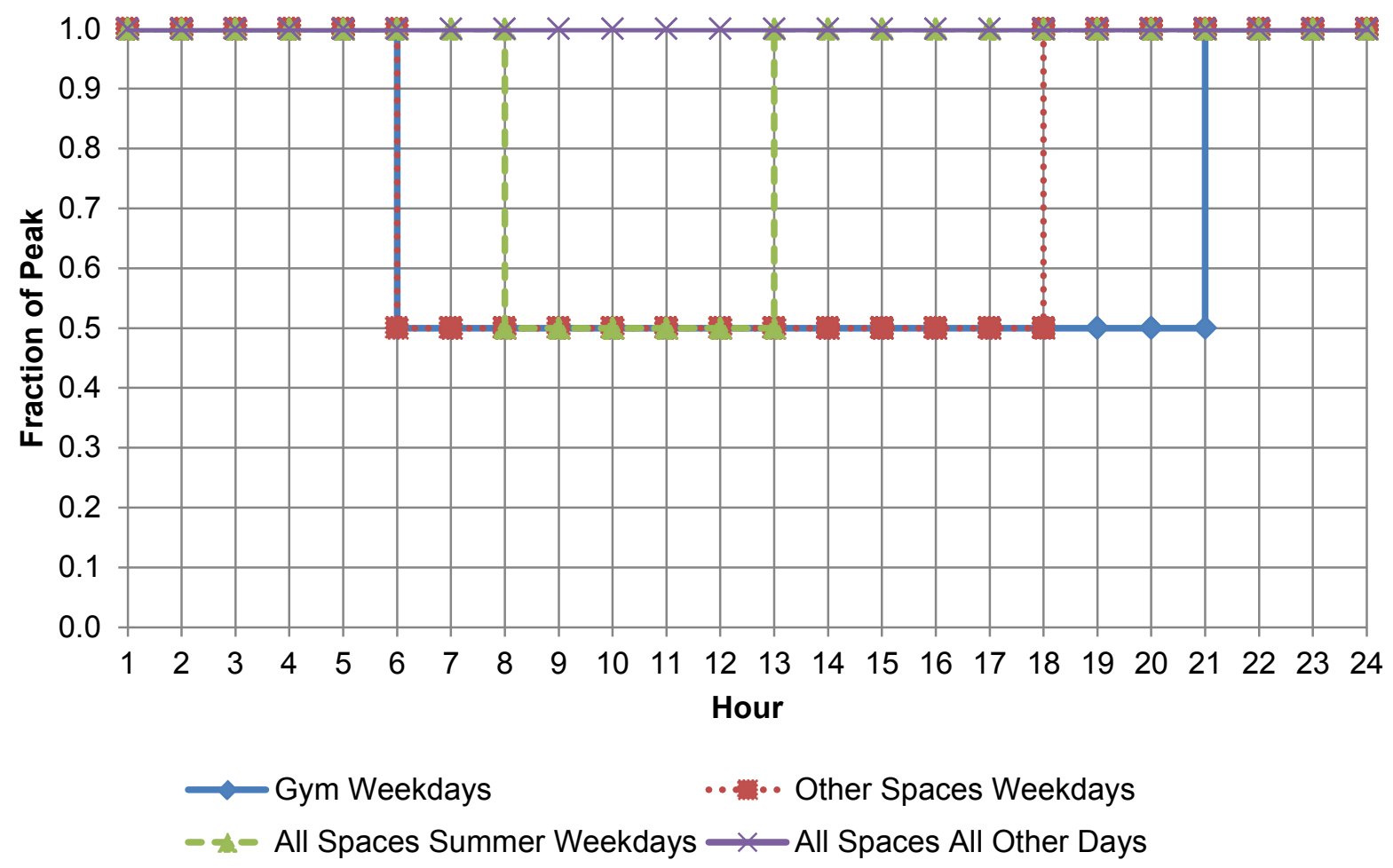

Figure 14. Primary school infiltration schedule 


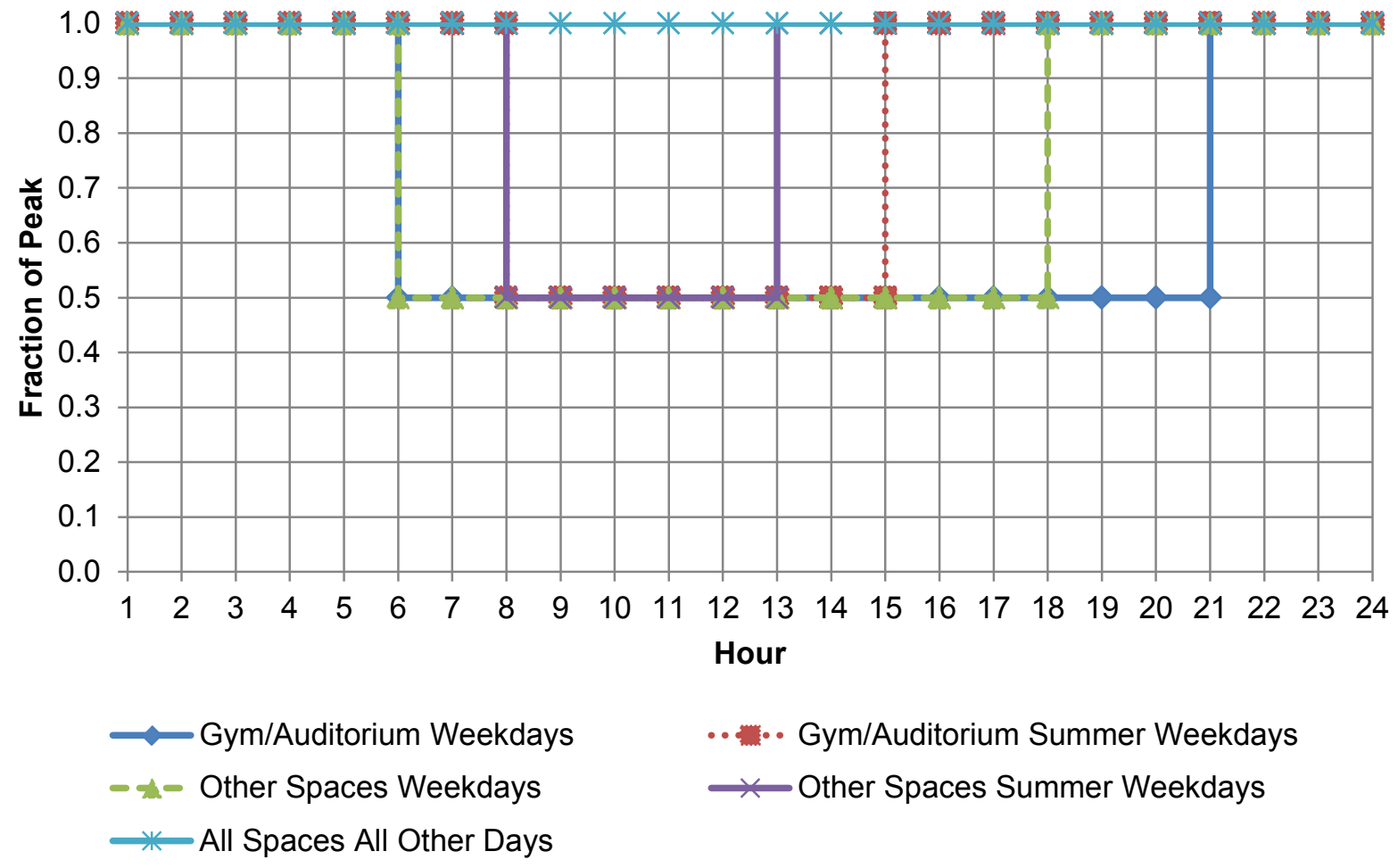

Figure 15. Secondary school infiltration schedule

\section{Electric Lighting}

Interior Lighting

The lighting power densities (LPDs) used in the models are listed in Table 13. 
Table 13. LPDs by Space Type

\begin{tabular}{lcc}
\hline Space Type & $\begin{array}{c}\text { Feasibility } \\
\text { Study LPD } \\
\left(\mathbf{W} / \mathbf{f t}^{2}\right)\end{array}$ & $\begin{array}{c}\mathbf{9 0 . 1 - 2 0 1 3} \\
\text { LPD }\left(\mathbf{W} / \mathbf{f t}^{2}\right)\end{array}$ \\
\hline Auditorium & 0.50 & 0.63 \\
Art room & 0.45 & 1.24 \\
Cafeteria & 0.50 & 0.65 \\
Classroom & 0.45 & 1.24 \\
Corridor & 0.40 & 0.66 \\
Gym/multipurpose room & 0.75 & 1.20 \\
Kitchen & 0.45 & 1.21 \\
Library/media center & 0.45 & 1.06 \\
Lobby & 0.50 & 0.90 \\
Mechanical & 0.40 & 0.42 \\
Office & 0.50 & 0.98 \\
Restroom & 0.50 & 0.98 \\
Whole building & 0.50 & 0.87 \\
\hline
\end{tabular}

The peak values shown in Table 13 were modified with hour-by-hour multiplier schedules in EnergyPlus. The primary and the secondary schools used the schedules shown in Figure 16. The lighting schedules were adapted by Bonnema et al. (2013) from those in Deru et al. (2011). The schedules were modified using industry experience with schools along with submetered data collected from actual schools. 


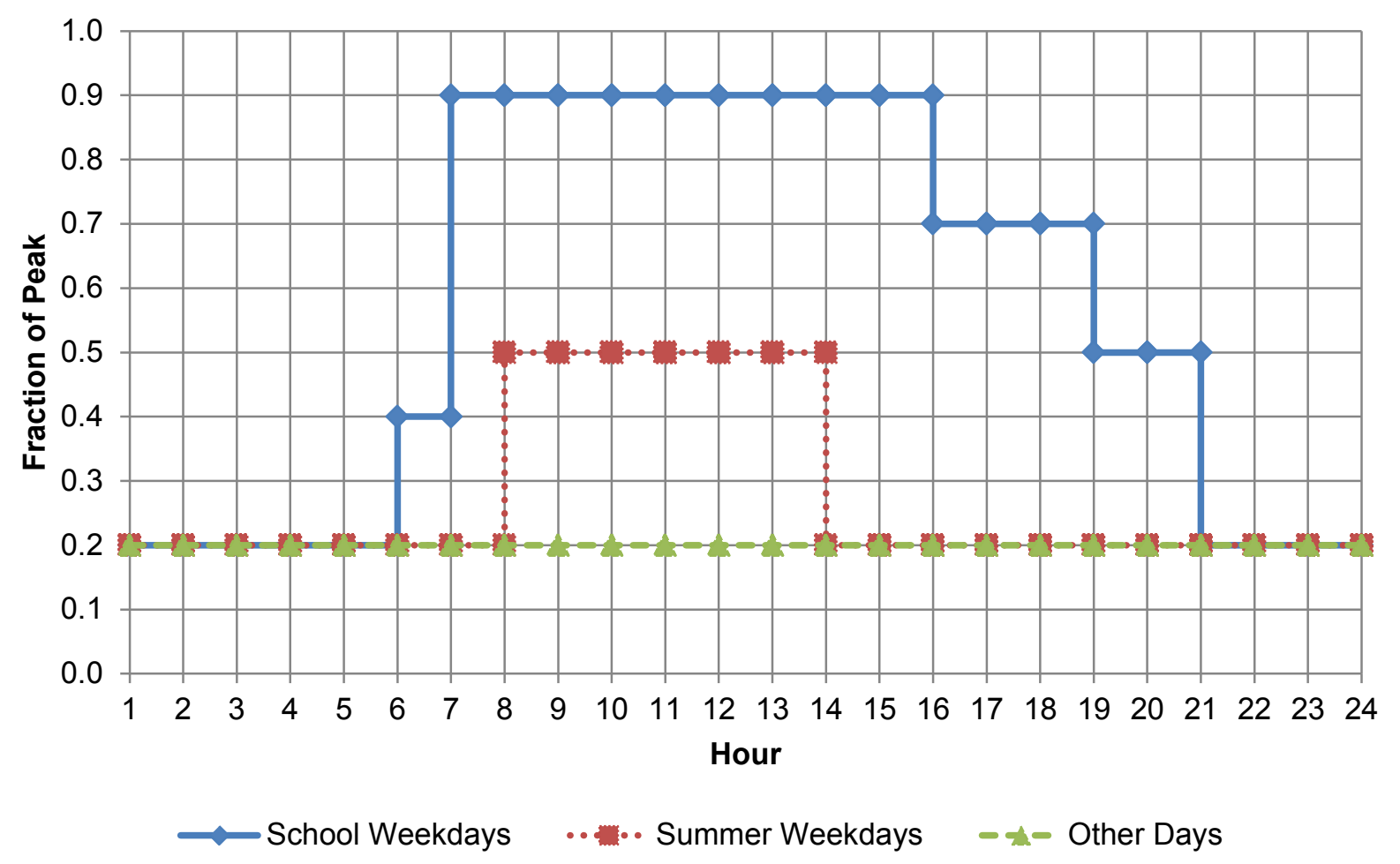

Figure 16. Lighting schedule

\section{Daylighting}

Daylight modeling was performed using the built-in EnergyPlus daylighting capabilities. The strategy was to daylight the half of the classroom that was near the view windows, whereas the other half would be illuminated by the light-emitting diode (LED) lights. In other words, the classroom would be bilevel switched with the daylighting controls dimming the LED lights in the half of the classroom near the windows. The target daylight illuminance was approximately 431 lux (40 foot-candles), and the lighting controls were modeled as continuous dimming from $0 \%-100 \%$ using a closed-loop control scheme. The calculation grid was placed $30 \mathrm{in}$. above the finished floor with 2-foot (ft) on-center spacing and a 2-ft wall offset. The assumed room surface properties were:

- A $90 \%$ ceiling reflectance

- A $60 \%$ wall reflectance

- A 35\% floor reflectance.

\section{Exterior Lighting}

The primary school had 2,219 watts (W) of exterior lighting, and the secondary school had $18,980 \mathrm{~W}$ of exterior lighting. In both models, the lights were controlled by an astronomical clock that turned the lights on when the sun set and off when the sun rose. The models also employed an energy-saving feature that turned the lights to quarter power from midnight to 6 a.m. Note that the secondary schools have significantly more exterior lighting because of the much larger parking lots to accommodate staff and students. 


\section{Plug and Process Loads}

The electric plug and process loads in this feasibility study's energy models represent a spaceby-space $40 \%$ reduction compared to a typical school (except for the kitchen; see Section 2.2.4.1). To apply the reduction, first a baseline must be set. This baseline was the plug and process loads from the DOE commercial prototype buildings models (DOE 2014), with a few modifications based on industry feedback. An explanation of the modifications (by space type) follows:

- Art classroom. In this feasibility study, an art classroom was substituted for the computer classroom in the prototype model. This decision was based on industry input that most schools use laptop carts that are transferred from one room to another in lieu of dedicated computer laboratories. Also, the prototype models did not include an art room, and Bonnema et al. (2013) determined that art rooms were common enough to schools that one should be included. The art room electric load includes an 11,000-W kiln similar to the KM-1227-3 (Skutt 2012).

$\circ$ For the primary school, the kiln was modeled as firing from January-June and September-December from 4 p.m. on the fifteenth of each month to 6 a.m. on the sixteenth. This resulted in 10 firings per year at 14 hours each, for an annual total of 140 hours.

- For the secondary school, the kiln was modeled as firing from January-June and September-December from 4 p.m. to midnight on the first, eighth, and twentysecond of each month as well as from 4 p.m. on the fifteenth of each month to 6 a.m. on the sixteenth. This resulted in 40 firings per year-30 at 8 hours and 10 at 14 hours - for a total of 380 hours of operation per year.

- Auditorium (secondary school only), corridor, gym/multipurpose room, lobby, mechanical room, and restrooms. In these space types, Bonnema et al. (2013) reduced the primary school prototype model plug load values to zero and the secondary school prototype model plug load values to $0.2 \mathrm{~W} / \mathrm{ft}^{2}$. Bonnema et al. (2013) determined that plug loads in these spaces are not very common in primary schools and thus should be set to zero. Also, the researchers' experience showed that plug loads in these spaces are smaller than they are in the prototype model for the secondary school.

- Primary school cafeteria, library, and office. Bonnema et al. (2013) determined that 0.5 $\mathrm{W} / \mathrm{ft}^{2}$ was a more realistic number for the type of equipment that would typically be found in these space types.

The plug and process loads for the energy models are shown in Table 14 (electric) and Table 15 (gas). See Section 2.2.4.1 for details about the gas process loads. 
Table 14. Electric Plug and Process Loads

\begin{tabular}{lll}
\hline Space Type & $\begin{array}{l}\text { Primary School } \\
\left(\mathbf{W} / \mathbf{f t}^{2}\right)\end{array}$ & $\begin{array}{l}\text { Secondary School } \\
\left(\mathbf{W} / \mathbf{f t}^{\mathbf{2}}\right)\end{array}$ \\
\hline Auditorium & $\mathrm{NA}$ & 0.12 \\
Art classroom & 3.78 & 3.78 \\
Cafeteria & 0.30 & 1.08 \\
Classroom & 0.84 & 0.54 \\
Corridor & 0.00 & 0.12 \\
Gym/multipurpose room & 0.00 & 0.12 \\
Kitchen & 14.20 & 12.00 \\
Library/media center & 0.30 & 0.54 \\
Lobby & 0.00 & 0.24 \\
Mechanical room & 0.00 & 0.24 \\
Office & 0.30 & 0.60 \\
Restroom & 0.00 & 0.24 \\
Calculated whole building & 0.80 & 0.50 \\
\hline
\end{tabular}

Table 15. Gas Process Loads

\begin{tabular}{lll}
\hline Space Type & $\begin{array}{l}\text { Primary School } \\
\left(\mathrm{Btu} / \mathrm{h} \cdot \mathrm{ft}^{2}\right)\end{array}$ & $\begin{array}{l}\text { Secondary School } \\
\left(\mathrm{Btu} / \mathrm{h} \cdot \mathrm{ft}^{2}\right)\end{array}$ \\
\hline Kitchen & 53.0 & 94.5 \\
\hline
\end{tabular}

This $40 \%$ reduction in plug load density was determined by calculating the plug load density of a typical energy-efficient school and comparing it to a typical school. None of the calculated values were used in the models; instead, the calculation was performed only to determine the percent reduction to apply. The calculation for the percent plug load reduction follows:

- Instructional computer loads. This assumes that there are 3.8 students per computer (Fox 2005), the primary school with 650 students has approximately 171 student computers, and the secondary school with 1,200 students has approximately 316 computers. Assuming 30-W laptops or mini desktop computers and 18-W LED backlit flat-panel monitors, the total instructional computer load is $8,208 \mathrm{~W}$ for the primary school and $15,168 \mathrm{~W}$ for the secondary school.

- Staff computer loads. This assumes 20 students per staff member, resulting in 32 (rounded down from 32.5) staff members for the primary school and 60 staff members for the secondary school. For the same $30-\mathrm{W}$ computer and $18-\mathrm{W}$ monitor as the instructional computers, this results in a staff computer load of $1,536 \mathrm{~W}$ for the primary school and 2,880 W for the secondary school.

- Server loads. An energy-efficient server uses approximately $48 \mathrm{~W}$ per connected computer with a power usage effectiveness of 1.2, resulting in $58 \mathrm{~W}$ per computer. For the 171 instructional computers and 32 staff computers in the primary school, this 
resulted in a server load of $11,774 \mathrm{~W}$. For the 316 student computers and 60 staff computers in the secondary school, this resulted in a server load of 21,808 W 24 hours per day.

- Staff miscellaneous loads. It was recognized that the staff would have additional plug-in equipment in the school, so researchers made the following assumptions, which resulted in a total staff miscellaneous load of $34,019 \mathrm{~W}$ for the primary school and 63,786 $\mathrm{W}$ for the secondary school:

- Each classroom has an energy-efficient $80-\mathrm{W}$ television and a 40-W VCR/DVD player.

○ Two staff members share a $125-\mathrm{W}$ refrigerator and a $1,000-\mathrm{W}$ microwave.

- Four staff members share a 1,500-W space heater.

○ Ten staff members share a 5.6-W per gallon (gal) 10-gal fish tank.

- Office loads. An additional $85 \mathrm{~W}$ per staff member was included for items such as task lights, phones, printers, and other office equipment. This resulted in an office load for the primary school of 2,720 W and 5,100 W for the secondary school.

- Total. The total plug load for the $73,962-\mathrm{ft}^{2}$ primary school is $58,257 \mathrm{~W}$, or $0.8 \mathrm{~W} / \mathrm{ft}^{2}$. The total plug load for the $210,892-\mathrm{ft}^{2}$ secondary school is $108,742 \mathrm{~W}$, or $0.5 \mathrm{~W} / \mathrm{ft}^{2}$.

Repeating the same calculation for a typical school with a $150-\mathrm{W}$ computer, a $70-\mathrm{W}$ monitor, a $65-\mathrm{W}$ server with a 1.9 power usage effectiveness (123 W per computer), and $107 \mathrm{~W}$ per staff member for office loads results in 107,072 W $\left(1.4 \mathrm{~W} / \mathrm{ft}^{2}\right)$ for the primary school and 199,174 W $\left(0.9 \mathrm{~W} / \mathrm{ft}^{2}\right)$ for the secondary school. Comparing the plug loads in this feasibility study to those of a typical school shows an approximate $40 \%$ reduction.

The peak values shown in Table 14 were modified with hour-by-hour multiplier schedules in EnergyPlus. All of the primary school electric loads (except those for the art room and kitchen) were modified by the schedule shown in Figure 17. The primary school kitchen loads were modified by the schedule depicted in Figure 18(electric equipment) and Figure 19 (gas equipment). Likewise for the secondary school, all the electric loads except for the kitchen loads were modified by the schedule illustrated in Figure 20; and the kitchen loads were modified by the schedule detailed in Figure 21 (electric equipment) and Figure 22 (gas equipment). The electric equipment (not including the kitchen loads) schedules in the model were adapted by Bonnema et al. (2013) from those developed in Deru et al. (2011). Bonnema et al. (2013) modified the schedules using industry experience with schools along with submetered data collected from actual schools. Additionally, the electric equipment (not including the kitchen) schedules in these feasibility study models have the same values during operating hours as those of the prototype models. For the feasibility study models, however, the schedule values during nonoperating hours were reduced to simulate the improved plug load control strategies in this study. For the primary school, this schedule value decreased from 0.4 to 0.15 ; and for the secondary school, this value decreased from 0.5 to 0.25 . These schedule modifications were meant to represent items such as computer power management, plug strip controls, and improved central server controls. They are in addition to the plug load reductions shown in Table 14. 


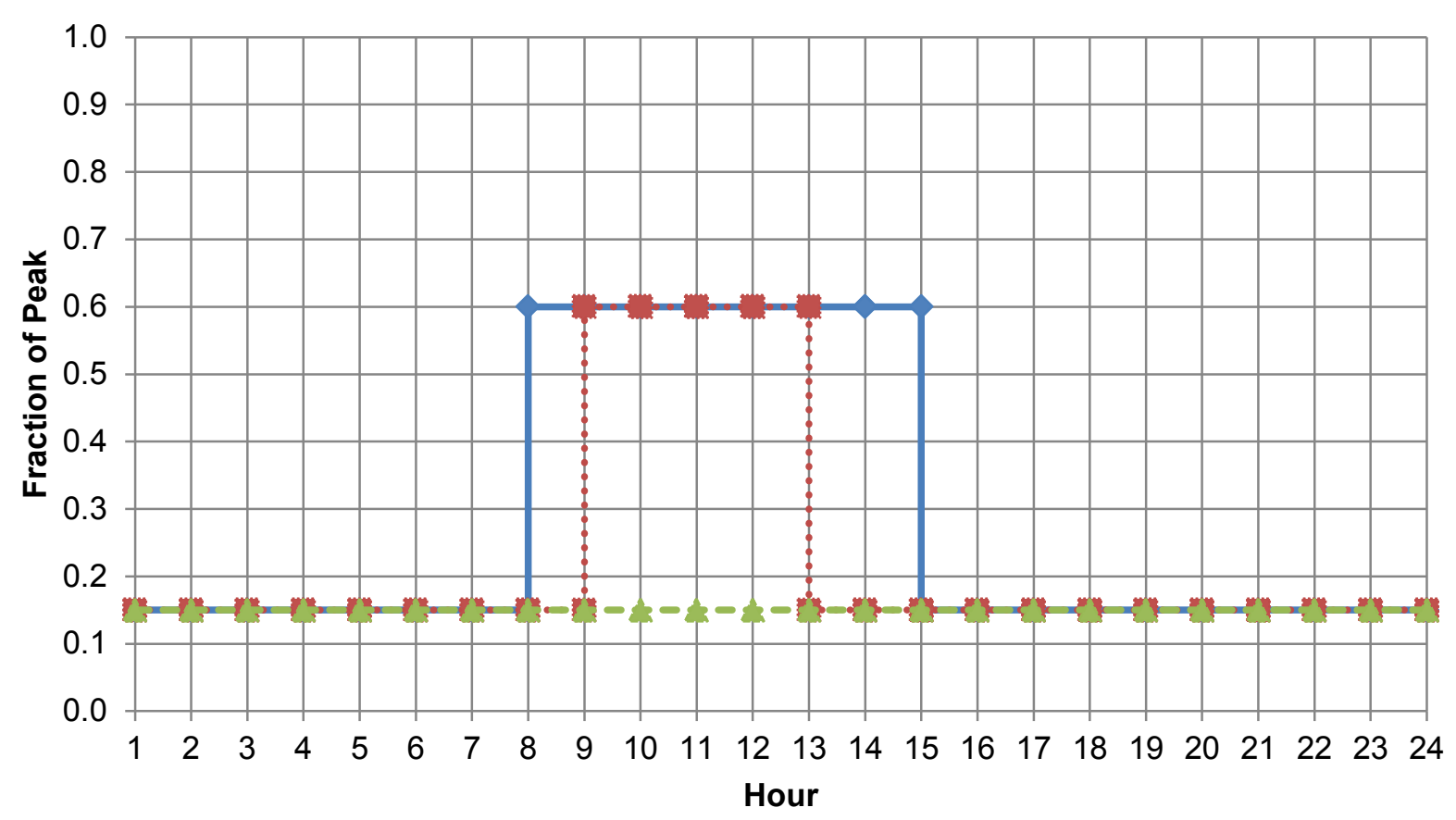

$\longrightarrow$ School Weekdays $\quad \cdots \cdot$ Summer Weekdays $\quad-\rightarrow-$ Other Days

Figure 17. Primary school electric equipment schedule

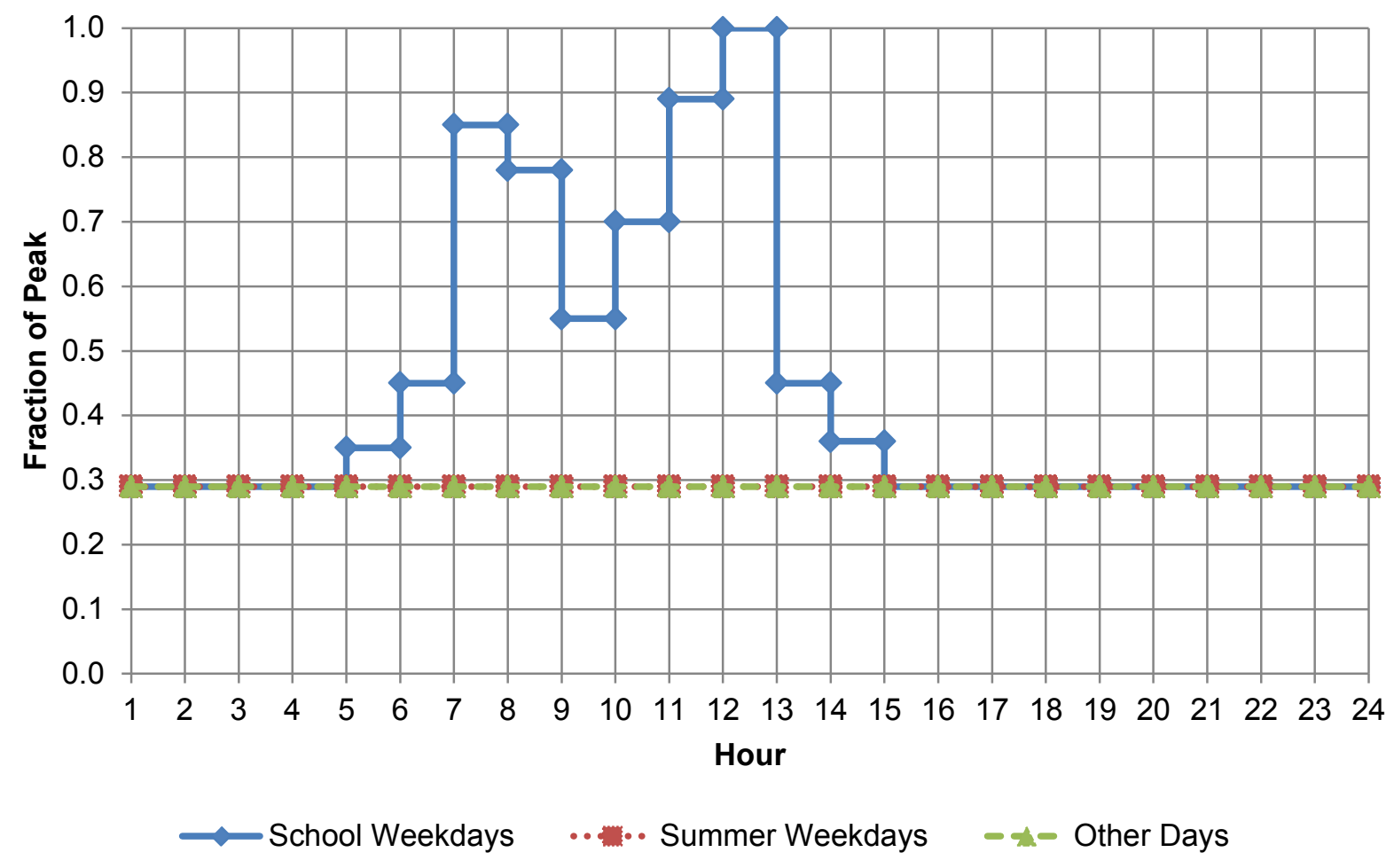

Figure 18. Primary school kitchen electric equipment schedule 


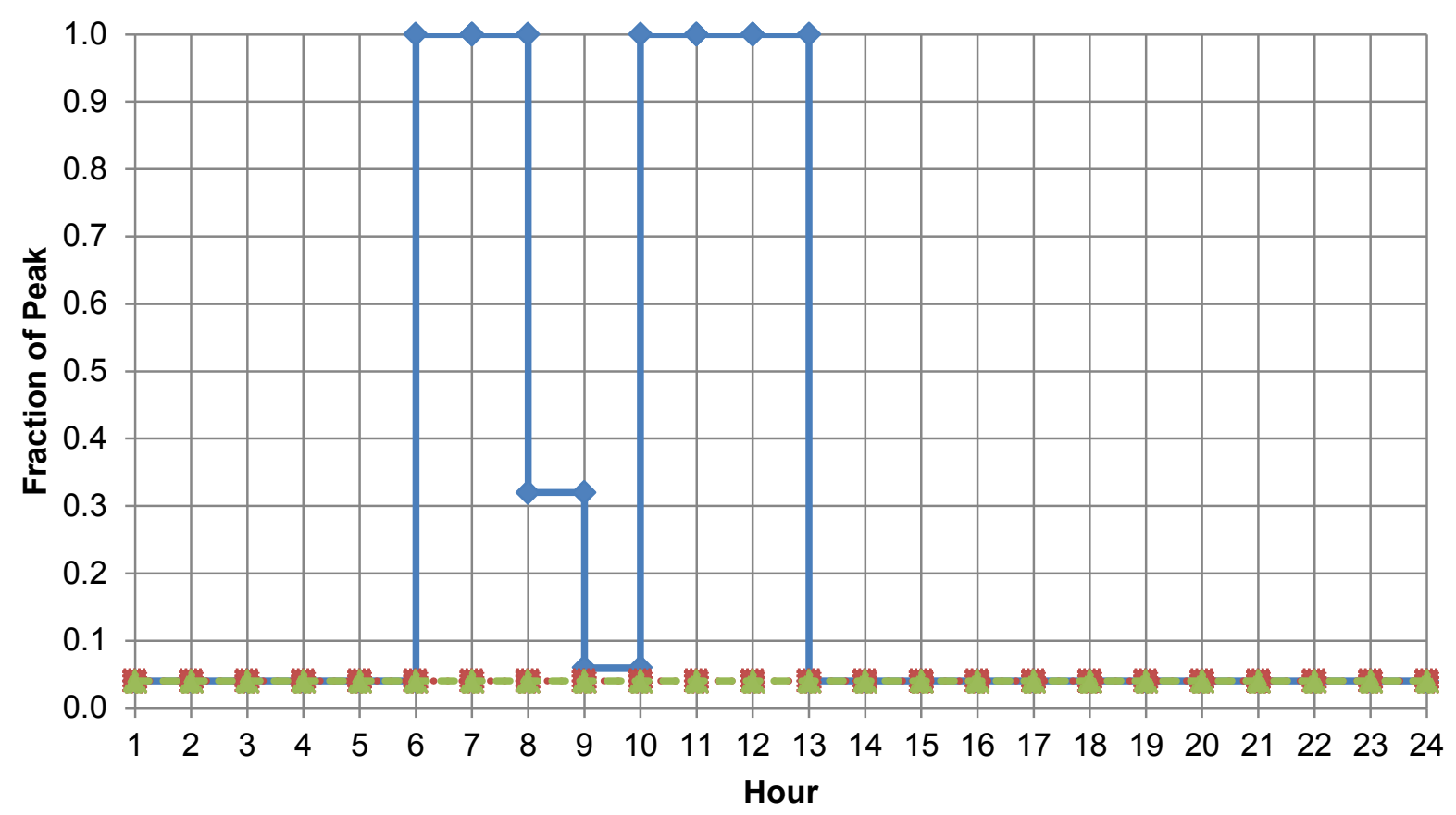

$\multimap$ School Weekdays $\quad \cdots+$ Summer Weekdays $\quad-\rightarrow-$ Other Days

Figure 19. Primary school kitchen gas equipment schedule

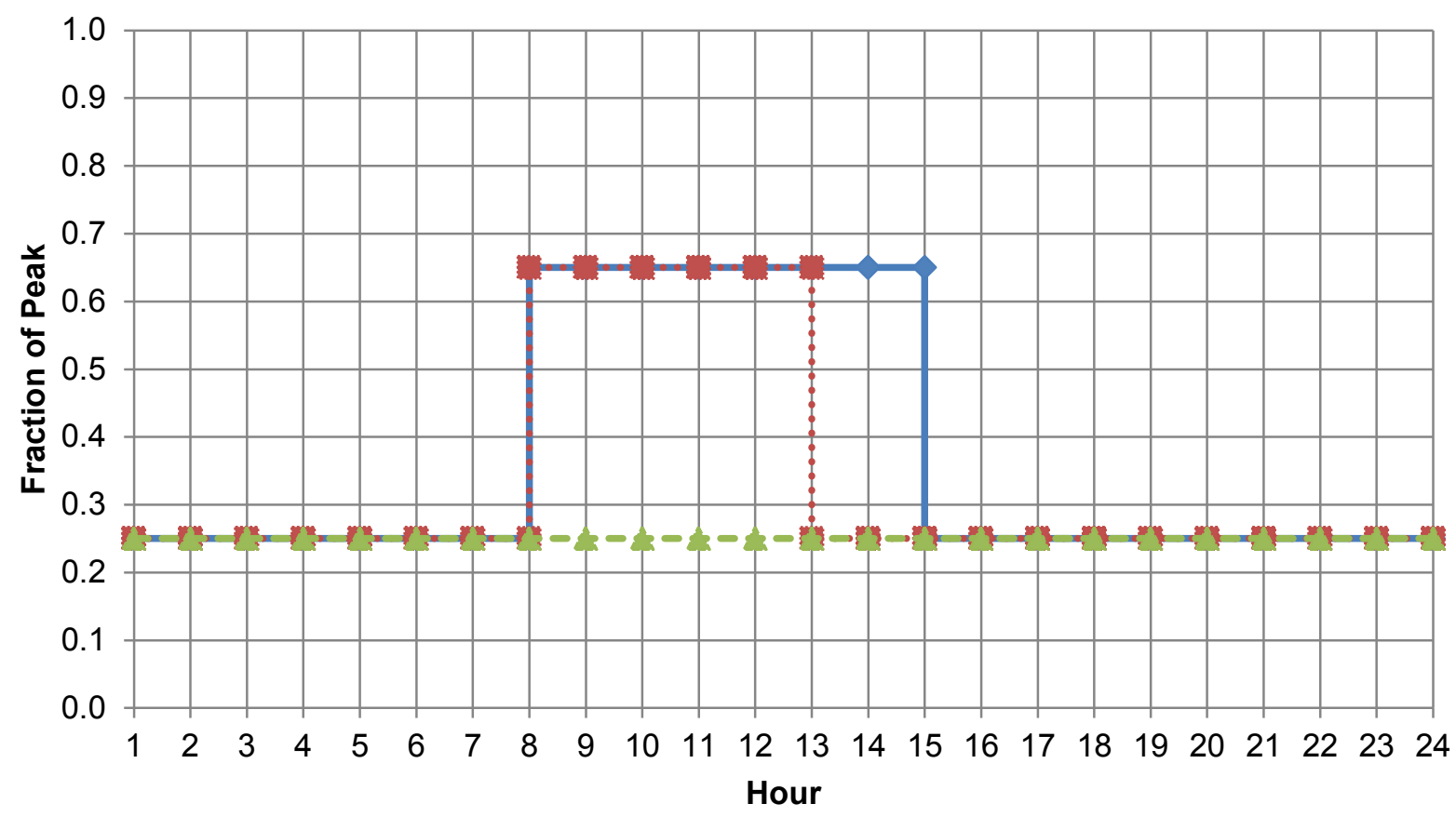

$\longrightarrow$ School Weekdays $\quad \cdots+$ Summer Weekdays $\quad-\rightarrow$ - Other Days

Figure 20. Secondary school electric equipment schedule 


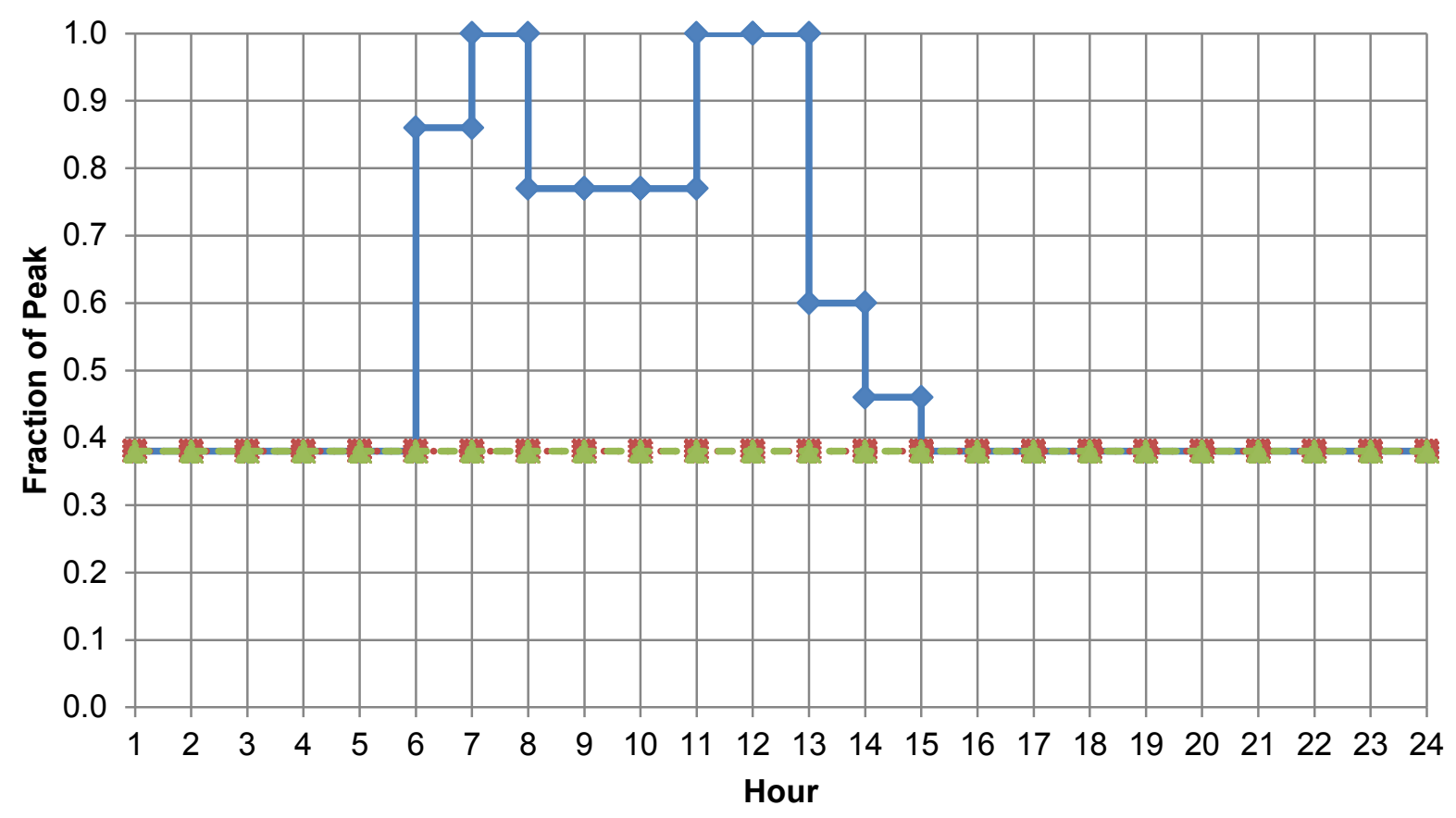

$\multimap$ School Weekdays $\quad \cdots+$ Summer Weekdays $\quad-\rightarrow-$ Other Days

Figure 21. Secondary school kitchen electric equipment schedule

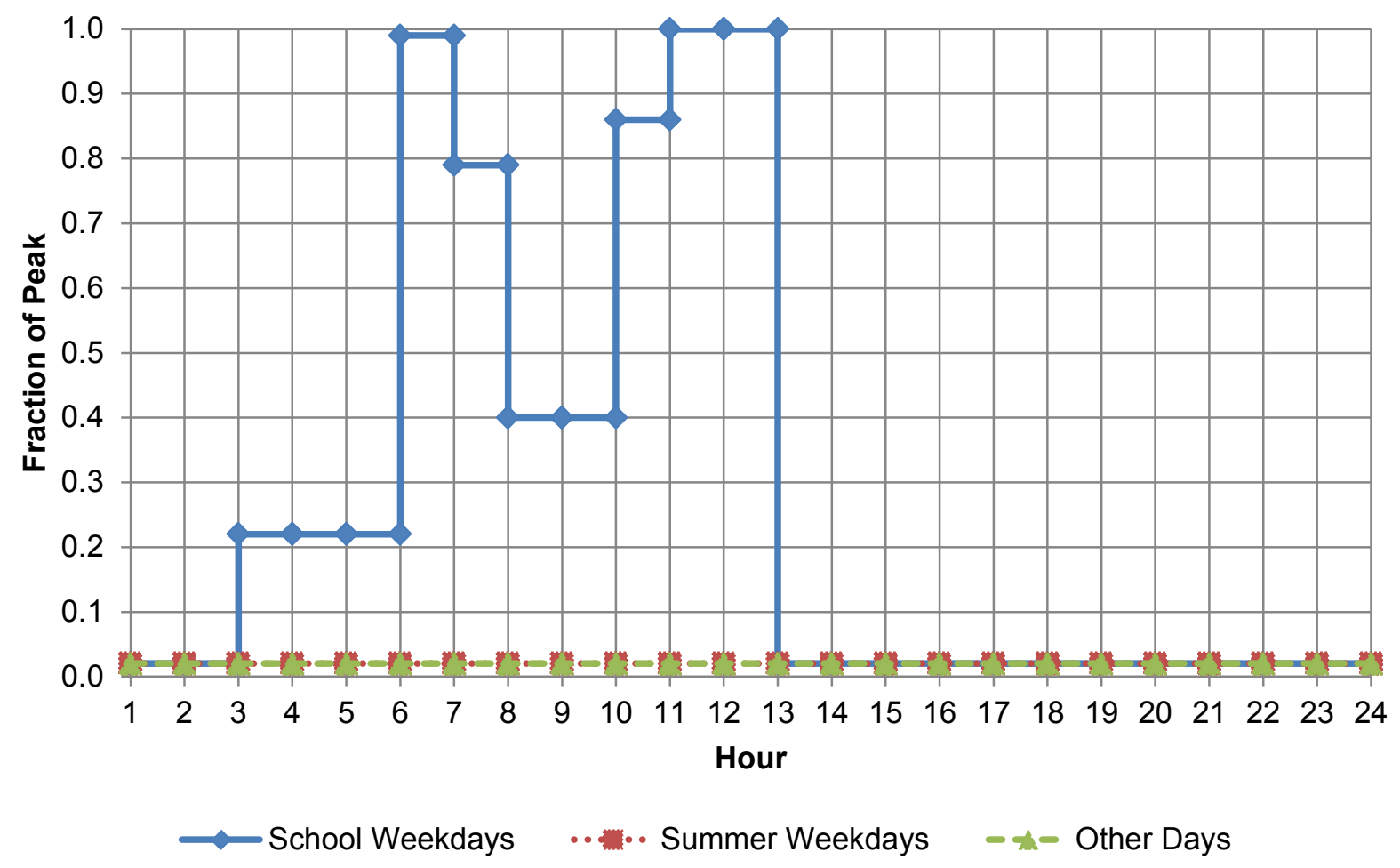

Figure 22. Secondary school zero kitchen gas equipment schedule 


\section{Kitchen}

For the primary school, Table 16 and Table 18 show the energy load profile data used in the development of the kitchen loads. These data were transformed into an input for electric equipment in EnergyPlus by determining the maximum value of the day and using the rest of the data to determine the multiplier schedule shown in Figure 18 for electric equipment and Figure 19 for gas equipment.

For the secondary school, Table 17 and Table 19 show the energy load profile data used in the development of the kitchen loads. The data in the tables represent "typical" K-12 kitchens, and fractional quantities are used in some instances (e.g., one of two kitchens has a toaster, so the quantity is 0.5). Bonnema et al. (2013) consulted with a commercial kitchen expert to help develop these data, which represent a best-in-class $\mathrm{K}-12$ school kitchen. The use factor column represents the fraction of rated power the equipment will draw during service. These data were transformed into an input for electric equipment in EnergyPlus by determining the maximum value of the day and using the rest of the data to determine the multiplier schedule shown in Figure 21 for electric equipment and Figure 22 for gas equipment. 
Table 16. Primary School Kitchen Load Profile-Electric Equipment

\begin{tabular}{|c|c|c|c|c|c|c|c|c|c|c|c|c|c|c|c|}
\hline \multirow{2}{*}{ Qty. } & \multirow{2}{*}{ Appliance } & \multirow{2}{*}{$\begin{array}{l}\text { Avg. } \\
\text { Input } \\
\text { Rate } \\
\left(k W^{a}\right)\end{array}$} & \multirow{2}{*}{$\begin{array}{l}\text { Use } \\
\text { Factor }\end{array}$} & \multicolumn{11}{|l|}{$\begin{array}{l}\text { Hour } \\
\text { (kW) }\end{array}$} & \multirow{2}{*}{$\begin{array}{l}\text { Total } \\
\text { per } \\
\text { Day } \\
(k W)\end{array}$} \\
\hline & & & & $1-6$ & 7 & 8 & 9 & 10 & 11 & 12 & 13 & 14 & 15 & $16-24$ & \\
\hline 1.0 & Steamer & 4.13 & 0.5 & 0.00 & 0.00 & 0.00 & 0.00 & 0.00 & 2.06 & 2.06 & 2.06 & 0.00 & 0.00 & 0.00 & 6.2 \\
\hline 1.0 & Hot holding cabinet & 0.40 & 1.0 & 0.00 & 0.40 & 0.40 & 0.40 & 0.00 & 0.40 & 0.40 & 0.40 & 0.00 & 0.00 & 0.00 & 2.4 \\
\hline 8.0 & Steam table & 0.80 & 0.5 & 0.00 & 0.00 & 3.20 & 0.00 & 0.00 & 0.00 & 3.20 & 3.20 & 0.00 & 0.00 & 0.00 & 9.6 \\
\hline 0.5 & Toaster & 1.50 & 0.5 & 0.00 & 0.00 & 0.38 & 0.00 & 0.00 & 0.00 & 0.38 & 0.38 & 0.00 & 0.00 & 0.00 & 1.1 \\
\hline 4.0 & Warming drawer & 0.10 & 0.5 & 0.00 & 0.20 & 0.20 & 0.20 & 0.20 & 0.20 & 0.20 & 0.20 & 0.00 & 0.00 & 0.00 & 1.4 \\
\hline 4.0 & Heat lamp & 1.00 & 0.5 & 0.00 & 0.00 & 2.00 & 2.00 & 2.00 & 2.00 & 2.00 & 2.00 & 0.00 & 0.00 & 0.00 & 12.0 \\
\hline 2.5 & Microwave & 0.40 & 0.5 & 0.00 & 0.00 & 0.50 & 0.00 & 0.00 & 0.50 & 0.50 & 0.00 & 0.00 & 0.00 & 0.00 & 1.5 \\
\hline 4.0 & Soup warmer & 0.50 & 1.0 & 0.00 & 2.00 & 2.00 & 0.00 & 0.00 & 2.00 & 2.00 & 0.00 & 0.00 & 0.00 & 0.00 & 8.0 \\
\hline 2.0 & Coffee brewer & 1.00 & 0.8 & $0.00^{\mathrm{b}}$ & 1.60 & 1.60 & 1.60 & 1.60 & 1.60 & 1.60 & 1.60 & 0.00 & 0.00 & 0.00 & 12.8 \\
\hline 5.0 & Cold table & 0.20 & 1.0 & 1.00 & 1.00 & 1.00 & 1.00 & 1.00 & 1.00 & 1.00 & 1.00 & 1.00 & 1.00 & 1.00 & 24.0 \\
\hline 1.0 & Ice machine & 0.77 & 1.0 & 0.77 & 0.77 & 0.77 & 0.77 & 0.77 & 0.77 & 0.77 & 0.77 & 0.77 & 0.77 & 0.77 & 18.5 \\
\hline 1.0 & Ice machine & 1.70 & 1.0 & 1.70 & 1.70 & 1.70 & 1.70 & 1.70 & 1.70 & 1.70 & 1.70 & 1.70 & 1.70 & 1.70 & 40.8 \\
\hline 6.0 & Prep table & 0.20 & 1.0 & 1.20 & 1.20 & 1.20 & 1.20 & 1.20 & 1.20 & 1.20 & 1.20 & 1.20 & 1.20 & 1.20 & 28.8 \\
\hline 2.5 & $\begin{array}{l}\text { Undercounter } \\
\text { refrigerator }\end{array}$ & 0.10 & 1.0 & 0.25 & 0.25 & 0.25 & 0.25 & 0.25 & 0.25 & 0.25 & 0.25 & 0.25 & 0.25 & 0.25 & 6.0 \\
\hline 2.0 & Undercounter freezer & 0.20 & 1.0 & 0.40 & 0.40 & 0.40 & 0.40 & 0.40 & 0.40 & 0.40 & 0.40 & 0.40 & 0.40 & 0.40 & 9.6 \\
\hline 5.0 & Refrigerator/solid & 0.13 & 1.0 & 0.65 & 0.65 & 0.65 & 0.65 & 0.65 & 0.65 & 0.65 & 0.65 & 0.65 & 0.65 & 0.65 & 15.6 \\
\hline 2.0 & Freezer/solid & 0.36 & 1.0 & 0.72 & 0.72 & 0.72 & 0.72 & 0.72 & 0.72 & 0.72 & 0.72 & 0.72 & 0.72 & 0.72 & 17.3 \\
\hline 1.3 & Freezer/glass & 0.50 & 1.0 & 0.65 & 0.65 & 0.65 & 0.65 & 0.65 & 0.65 & 0.65 & 0.65 & 0.65 & 0.65 & 0.65 & 15.6 \\
\hline 1.0 & Dish machine, conveyor & 4.50 & 1.0 & 0.00 & 0.00 & 2.25 & 4.50 & 1.00 & 1.00 & 2.25 & 4.50 & 2.25 & 1.00 & 0.00 & 18.8 \\
\hline 1.0 & $\begin{array}{l}\text { Dish machine, booster } \\
\text { heater }\end{array}$ & 4.00 & 1.0 & 0.00 & 0.00 & 2.00 & 4.00 & 2.00 & 1.00 & 1.00 & 4.00 & 2.00 & 1.00 & 0.00 & 17.0 \\
\hline \multicolumn{2}{|c|}{ Total $(\mathrm{kW})$} & & & $7.3^{\mathrm{C}}$ & 11.5 & 21.9 & 20.0 & 14.1 & 18.1 & 22.9 & 25.7 & 11.6 & 9.3 & 7.3 & 267 \\
\hline
\end{tabular}


Table 17. Secondary School Kitchen Load Profile-Electric Equipment

\begin{tabular}{|c|c|c|c|c|c|c|c|c|c|c|c|c|c|c|c|}
\hline \multirow{2}{*}{ Qty. } & \multirow{2}{*}{ Appliance } & \multirow{2}{*}{$\begin{array}{l}\text { Avg. } \\
\text { Input } \\
\text { Rate } \\
\text { (kW) }\end{array}$} & \multirow{2}{*}{$\begin{array}{l}\text { Use } \\
\text { Factor }\end{array}$} & \multicolumn{11}{|l|}{$\begin{array}{l}\text { Hour } \\
\text { (kW) }\end{array}$} & \multirow{2}{*}{$\begin{array}{l}\text { Total } \\
\text { per } \\
\text { Day } \\
\text { (kW) }\end{array}$} \\
\hline & & & & $1-6$ & 7 & 8 & 9 & 10 & 11 & 12 & 13 & 14 & 15 & $16-24$ & \\
\hline 1.0 & Steamer & 4.13 & 1.0 & 0.00 & 2.06 & 2.06 & 0.00 & 0.00 & 4.13 & 4.13 & 0.00 & 0.00 & 0.00 & 0.00 & 12.4 \\
\hline 3.0 & Hot holding cabinet & 0.40 & 0.5 & 0.00 & 0.60 & 0.60 & 0.60 & 0.60 & 0.60 & 0.60 & 0.60 & 0.00 & 0.00 & 0.00 & 4.2 \\
\hline 10.0 & Steam table & 0.80 & 0.5 & 0.00 & 4.00 & 4.00 & 4.00 & 4.00 & 4.00 & 4.00 & 4.00 & 0.00 & 0.00 & 0.00 & 28.0 \\
\hline 2.0 & Contact toaster & 1.50 & 0.5 & 0.00 & 3.00 & 3.00 & 0.00 & 0.00 & 0.00 & 3.00 & 3.00 & 0.00 & 0.00 & 0.00 & 12.0 \\
\hline 1.5 & Conveyor toaster & 1.80 & 0.5 & 0.00 & 2.70 & 2.70 & 0.00 & 0.00 & 0.00 & 2.70 & 2.70 & 0.00 & 0.00 & 0.00 & 10.8 \\
\hline 8.0 & Warming drawer & 0.10 & 0.5 & 0.00 & 0.80 & 0.80 & 0.80 & 0.80 & 0.80 & 0.80 & 0.80 & 0.00 & 0.00 & 0.00 & 5.6 \\
\hline 5.0 & Heat lamp & 0.25 & 1.0 & 0.00 & 1.25 & 1.25 & 1.25 & 1.25 & 1.25 & 1.25 & 1.25 & 0.00 & 0.00 & 0.00 & 8.8 \\
\hline 3.0 & Microwave & 0.40 & 0.5 & 0.00 & 1.20 & 1.20 & 1.20 & 1.20 & 1.20 & 1.20 & 1.20 & 0.00 & 0.00 & 0.00 & 8.4 \\
\hline 5.0 & Soup warmer & 0.50 & 0.5 & 0.00 & 2.50 & 2.50 & 2.50 & 2.50 & 2.50 & 2.50 & 2.50 & 0.00 & 0.00 & 0.00 & 17.5 \\
\hline 3.0 & Coffee brewer & 1.00 & 0.5 & 0.00 & 3.00 & 3.00 & 3.00 & 3.00 & 3.00 & 3.00 & 3.00 & 0.00 & 0.00 & 0.00 & 21.0 \\
\hline 2.5 & Soft serve & 0.20 & 0.5 & 0.50 & 0.50 & 0.50 & 0.50 & 0.50 & 0.50 & 0.50 & 0.50 & 0.50 & 0.50 & 0.50 & 12.0 \\
\hline 2.0 & Drink machine & 0.20 & 0.5 & 0.40 & 0.40 & 0.40 & 0.40 & 0.40 & 0.40 & 0.40 & 0.40 & 0.40 & 0.40 & 0.40 & 9.6 \\
\hline 6.0 & Cold table & 0.10 & 0.5 & 0.60 & 0.60 & 0.60 & 0.60 & 0.60 & 0.60 & 0.60 & 0.60 & 0.60 & 0.60 & 0.60 & 14.4 \\
\hline 1.0 & Ice machine & 1.70 & 1.0 & 1.70 & 1.70 & 1.70 & 1.70 & 1.70 & 1.70 & 1.70 & 1.70 & 1.70 & 1.70 & 1.70 & 40.8 \\
\hline 1.0 & Ice machine & 2.37 & 1.0 & 2.37 & 2.37 & 2.37 & 2.37 & 2.37 & 2.37 & 2.37 & 2.37 & 2.37 & 2.37 & 2.37 & 56.9 \\
\hline 8.0 & Prep table & 0.20 & 0.5 & 1.60 & 1.60 & 1.60 & 1.60 & 1.60 & 1.60 & 1.60 & 1.60 & 1.60 & 1.60 & 1.60 & 38.4 \\
\hline 4.0 & $\begin{array}{l}\text { Undercounter } \\
\text { refrigerator }\end{array}$ & 0.09 & 1.0 & 0.37 & 0.37 & 0.37 & 0.37 & 0.37 & 0.37 & 0.37 & 0.37 & 0.37 & 0.37 & 0.37 & 8.9 \\
\hline 2.0 & Undercounter freezer & 0.23 & 1.0 & 0.46 & 0.46 & 0.46 & 0.46 & 0.46 & 0.46 & 0.46 & 0.46 & 0.46 & 0.46 & 0.46 & 11.0 \\
\hline 6.0 & Refrigerator/solid & 0.13 & 1.0 & 0.78 & 0.78 & 0.78 & 0.78 & 0.78 & 0.78 & 0.78 & 0.78 & 0.78 & 0.78 & 0.78 & 18.7 \\
\hline 2.5 & Freezer/solid & 0.36 & 1.0 & 0.90 & 0.90 & 0.90 & 0.90 & 0.90 & 0.90 & 0.90 & 0.90 & 0.90 & 0.90 & 0.90 & 21.6 \\
\hline 2.0 & Freezer/glass & 0.46 & 1.0 & 0.92 & 0.92 & 0.92 & 0.92 & 0.92 & 0.92 & 0.92 & 0.92 & 0.92 & 0.92 & 0.92 & 22.1 \\
\hline 1.0 & Dish machine, conveyor & 4.50 & 1.0 & 0.00 & 4.50 & 4.50 & 1.00 & 1.00 & 1.00 & 4.50 & 4.50 & 2.25 & 2.25 & 0.00 & 25.5 \\
\hline 1.0 & $\begin{array}{l}\text { Dish machine, booster } \\
\text { heater }\end{array}$ & 4.00 & 1.0 & 0.00 & 4.00 & 4.00 & 1.00 & 1.00 & 1.00 & 4.00 & 4.00 & 4.00 & 0.00 & 0.00 & 23.0 \\
\hline \multicolumn{4}{|c|}{ Total (kW) } & 10.6 & 40.2 & 40.2 & 26.0 & 26.0 & 30.1 & 42.3 & 38.2 & 16.9 & 12.9 & 10.6 & 432 \\
\hline
\end{tabular}


Table 18. Primary School Kitchen Load Profile-Gas Equipment

\begin{tabular}{|c|c|c|c|c|c|c|c|c|c|c|}
\hline \multirow{2}{*}{ Qty. } & \multirow{2}{*}{ Appliance } & \multirow{2}{*}{$\begin{array}{l}\text { Avg. } \\
\text { Input } \\
\text { Rate } \\
\text { (kBtu/h) }\end{array}$} & \multirow{2}{*}{$\begin{array}{l}\text { Use } \\
\text { Factor }\end{array}$} & \multicolumn{6}{|c|}{$\begin{array}{l}\text { Hour } \\
\text { (kBtu/h) }\end{array}$} & \multirow{2}{*}{$\begin{array}{c}\text { Total per } \\
\text { Day } \\
\text { (kBtu/h) }\end{array}$} \\
\hline & & & & $1-6$ & $7-8$ & 9 & 10 & $11-13$ & $14-24$ & \\
\hline 0.1 & Braising pan & 15.1 & 1.0 & 0.00 & 1.51 & 1.51 & 0.00 & 1.51 & 0.00 & 9.1 \\
\hline 1.0 & Griddle & 24.4 & 1.0 & 1.00 & 24.40 & 24.40 & 1.00 & 24.40 & 1.00 & 164.4 \\
\hline 0.1 & Combi oven & 25.8 & 1.0 & 0.00 & 2.58 & 2.58 & 2.58 & 2.58 & 0.00 & 18.1 \\
\hline 1 & Convection oven & 16.6 & 1.0 & 1.00 & 16.60 & 1.00 & 1.00 & 16.60 & 1.00 & 102.0 \\
\hline 1 & Range oven & 18.3 & 1.0 & 0.50 & 18.30 & 0.50 & 0.50 & 18.30 & 0.50 & 101.0 \\
\hline 1 & Open top range & 32.0 & 1.0 & 1.00 & 32.00 & 1.00 & 1.00 & 32.00 & 1.00 & 179.0 \\
\hline \multicolumn{2}{|c|}{ Total (kBtu/h) } & & & 3.5 & 95.4 & 31.0 & 6.1 & 95.4 & 3.5 & 574 \\
\hline
\end{tabular}

Table 19. Secondary School Kitchen Load Profile-Gas Equipment

\begin{tabular}{|c|c|c|c|c|c|c|c|c|c|c|c|c|}
\hline \multirow{2}{*}{ Qty. } & \multirow{2}{*}{ Appliance } & \multirow{2}{*}{$\begin{array}{l}\text { Avg. } \\
\text { Input } \\
\text { Rate } \\
\text { (kBtu/h) }\end{array}$} & \multirow{2}{*}{$\begin{array}{l}\text { Use } \\
\text { Factor }\end{array}$} & \multicolumn{8}{|c|}{$\underset{\text { (kBtu/h) }}{\text { Hour }}$} & \multirow{2}{*}{$\begin{array}{l}\text { Total per } \\
\text { Day } \\
\text { (kBtu/h) }\end{array}$} \\
\hline & & & & $1-3$ & $4-6$ & 7 & 8 & $9-10$ & 11 & $12-13$ & 14-24 & \\
\hline 1.00 & Braising pan & 15.1 & 0.5 & 0.00 & 0.00 & 7.55 & 7.55 & 3.78 & 7.55 & 7.55 & 0.00 & 45.3 \\
\hline 0.50 & Underfired broiler & 68.5 & 0.5 & 1.00 & 1.00 & 1.00 & 1.00 & 1.00 & 17.13 & 17.13 & 1.00 & 72.4 \\
\hline 2.00 & French fryer & 25.6 & 0.5 & 1.00 & 1.00 & 25.60 & 25.60 & 12.80 & 25.60 & 25.60 & 1.00 & 170.6 \\
\hline 2.00 & Standard griddle & 24.4 & 0.5 & 0.50 & 0.50 & 24.40 & 24.40 & 12.20 & 24.40 & 24.40 & 0.50 & 154.9 \\
\hline 4.00 & Convection oven & 16.6 & 0.5 & 1.00 & 1.00 & 33.20 & 33.20 & 16.60 & 33.20 & 33.20 & 1.00 & 216.2 \\
\hline 1.00 & Conveyor oven & 60.9 & 0.5 & 0.00 & 0.00 & 0.00 & 0.00 & 0.00 & 0.00 & 30.45 & 0.00 & 60.9 \\
\hline 2.00 & Deck oven & 44.7 & 0.5 & 0.00 & 44.70 & 44.70 & 0.00 & 0.00 & 0.00 & 0.00 & 0.00 & 178.8 \\
\hline 1.25 & Range oven & 18.3 & 0.5 & 0.00 & 0.00 & 11.44 & 11.44 & 5.72 & 11.44 & 11.44 & 0.00 & 68.6 \\
\hline 1.25 & Open top range & 32.0 & 0.5 & 1.00 & 1.00 & 20.00 & 20.00 & 10.00 & 20.00 & 20.00 & 1.00 & 137.0 \\
\hline 2.00 & Steam kettle & 50.0 & 0.5 & 0.00 & 0.00 & 50.00 & 50.00 & 25.00 & 50.00 & 50.00 & 0.00 & 300.0 \\
\hline \multicolumn{2}{|c|}{ Total $(\mathrm{kBtu} / \mathrm{h})$} & & & 4.5 & 49.2 & 217.9 & 173.2 & 87.1 & 189.3 & 219.8 & 4.5 & 1,405 \\
\hline
\end{tabular}




\section{Elevators}

The primary and secondary school models contain two and three stories, respectively, and thus have elevators. Information from the DOE commercial reference secondary school (Deru et al. 2011) was used, which contains two 14,610-W elevator motors with an efficiency of $91 \%$, resulting in a total elevator load of $32,110 \mathrm{~W}$. This load was applied to the primary school. The load was scaled for the additional floor in the secondary school, resulting in two $21,915-\mathrm{W}$ elevator motors with an efficiency of $91 \%$, for a total elevator load of $43,830 \mathrm{~W}$. The peak elevator load was modified by the schedule shown in Figure 23. The elevator load was applied to the ground-floor mechanical room zone in both models.

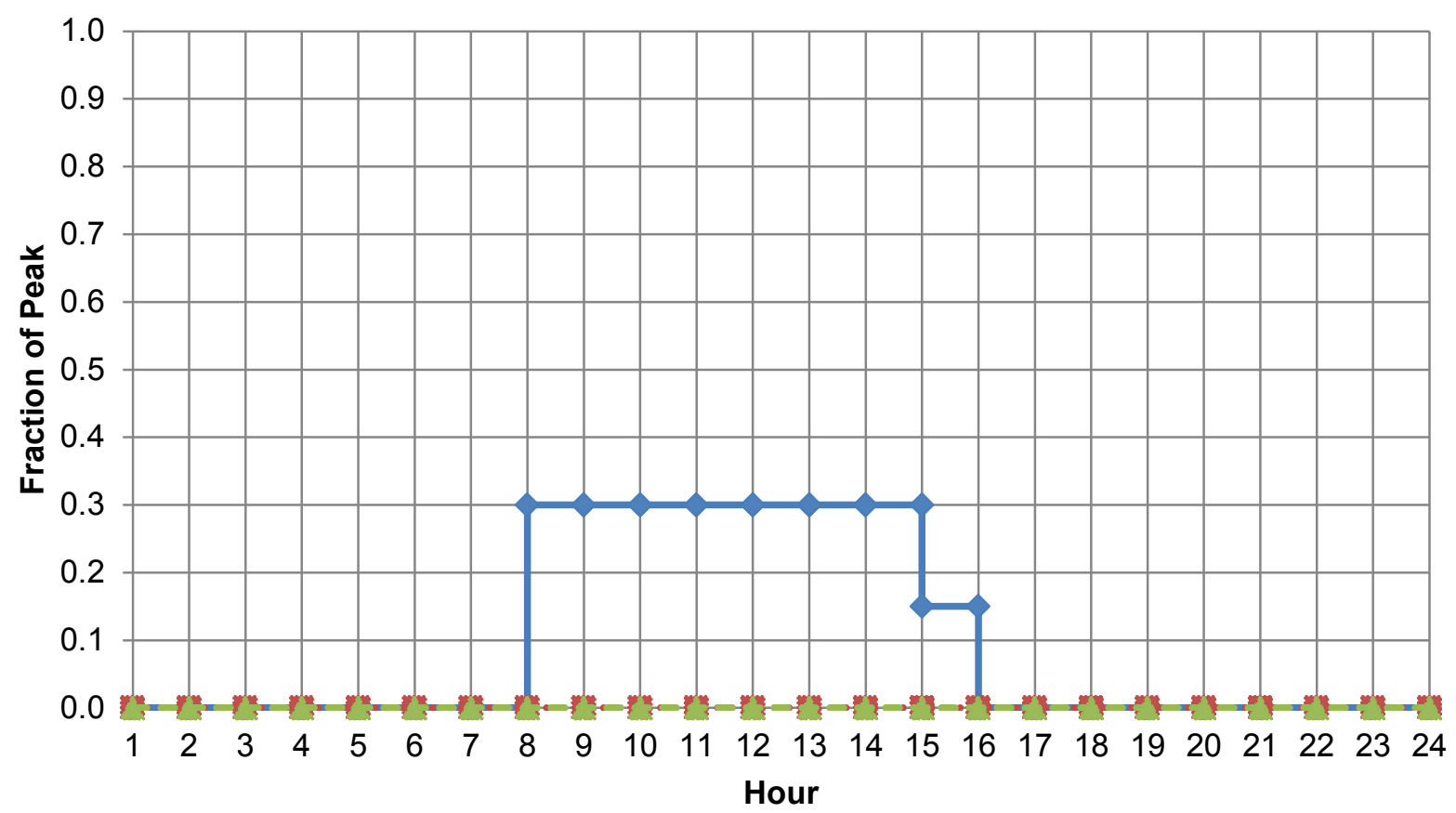

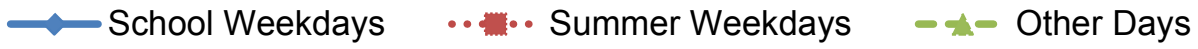

Figure 23. Secondary school elevator schedule

\section{Heating, Ventilating, and Air Conditioning}

Both models were similarly zoned: a central area consisting of common spaces connected the classroom wings. The classroom wings and most of the central common spaces were served by variable air volume (VAV) dedicated outdoor air system (DOAS) for ventilation along with a ground source heat pump (GSHP) in each zone for space conditioning. The specialty spaces with unusual loads (auditorium [secondary school only], cafeteria, kitchen, gym) were served by packaged single zone (PSZ) GSHP systems that provided both ventilation and space conditioning.

\section{Layout}

Figure 24 and Figure 25 shows the HVAC layout of the primary school baseline model. Zones with the same color are on the same HVAC system. The DOAS systems serve multiple zones, and the PSZ systems serve only one zone. Figure 26 through Figure 28 show the same information for the secondary school baseline model. The auditorium, gym, and auxiliary gym are two-story spaces. 


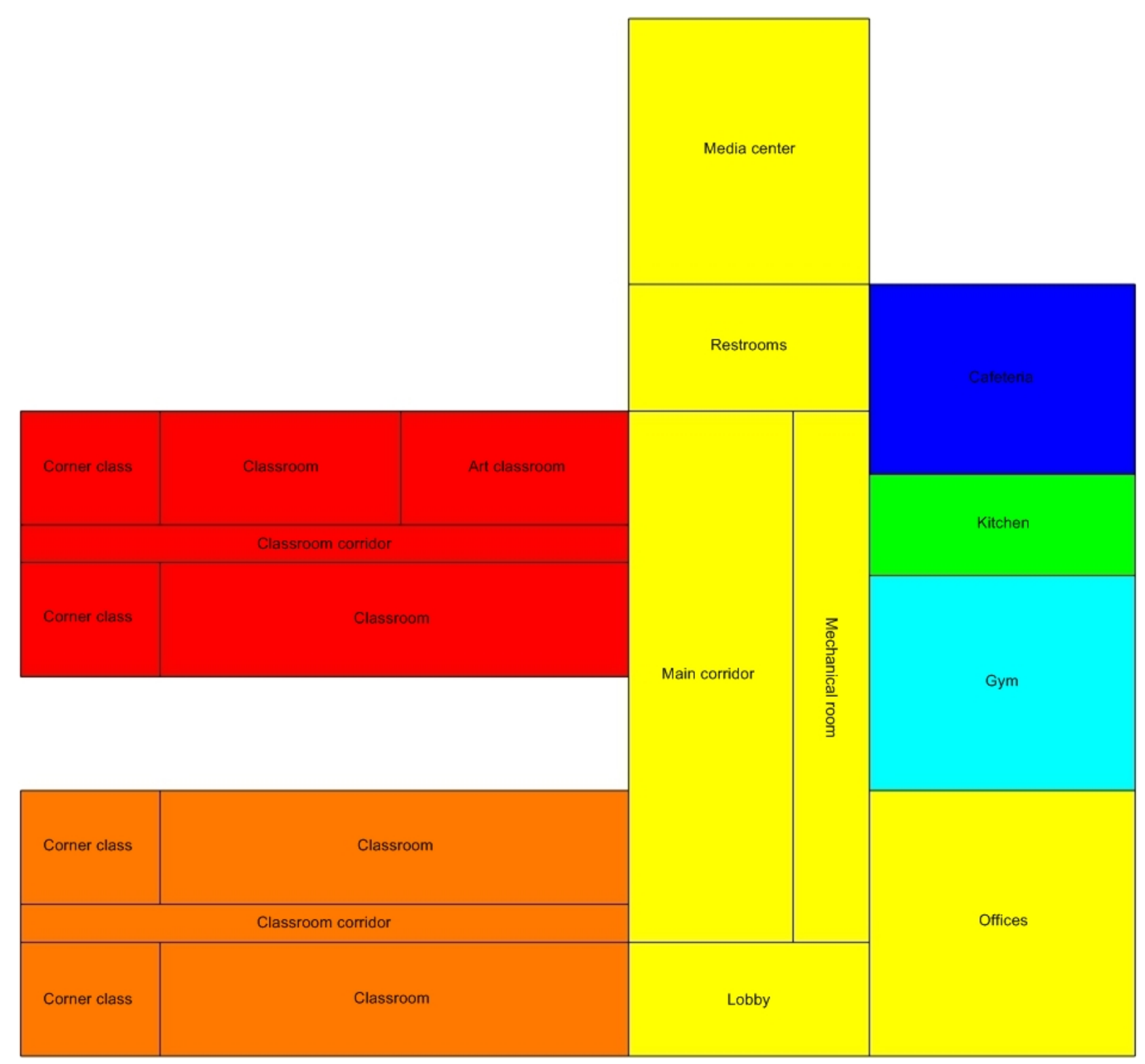

\begin{tabular}{|c|c|}
\hline & DOAS \\
1 \\
\hline & DOAS \\
2 \\
\hline & DOAS \\
3 \\
\hline & PSZ 1 \\
\hline & PSZ 2 \\
\hline & PSZ 3 \\
\hline
\end{tabular}

Figure 24. Primary school HVAC layout-first floor

This report is available at no cost from the National Renewable Energy Laboratory at www.nrel.gov/publications. 


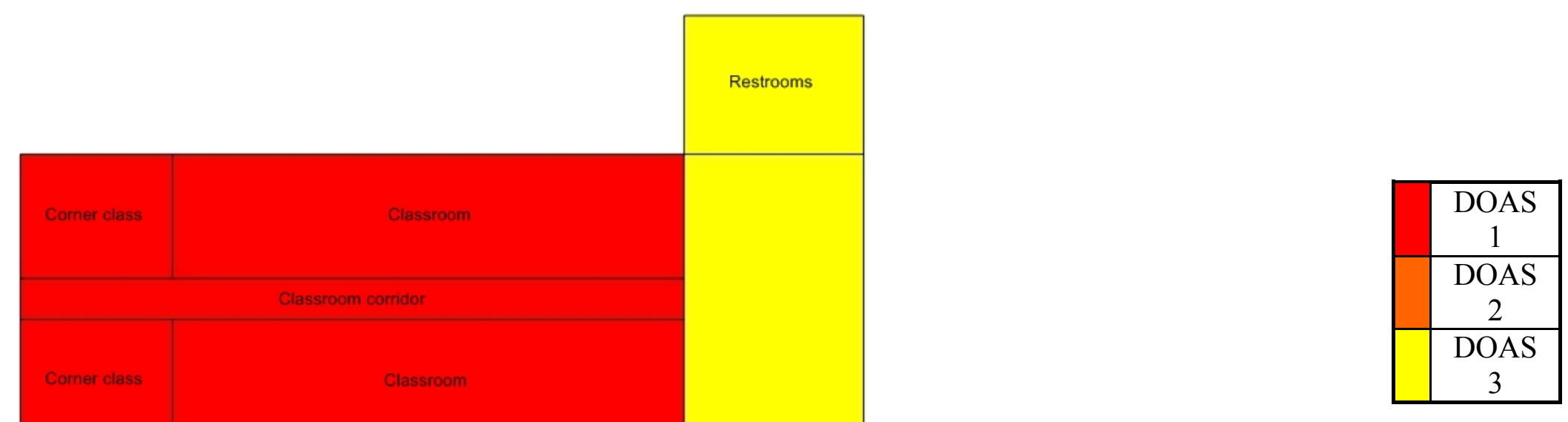

Main corridor

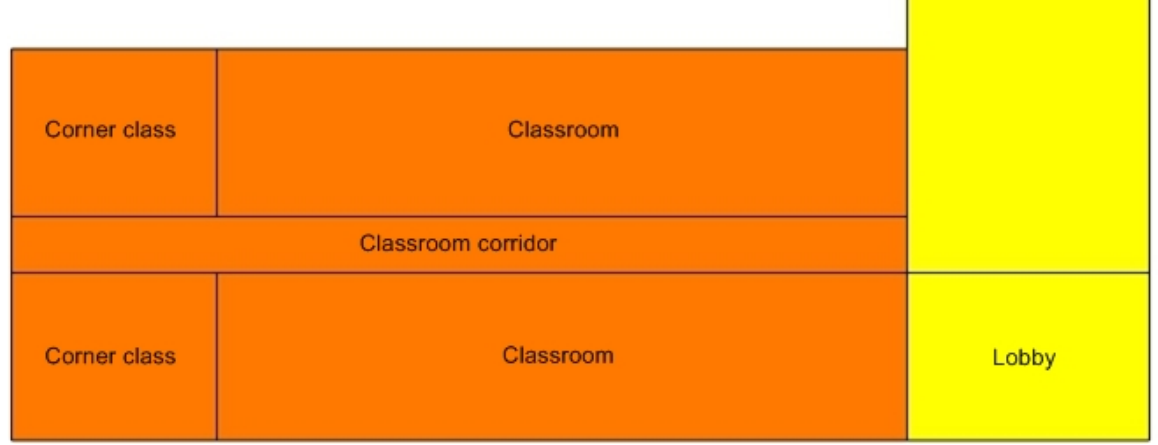

Figure 25. Primary school HVAC layout-second floor

This report is available at no cost from the National Renewable Energy Laboratory at www.nrel.gov/publications. 


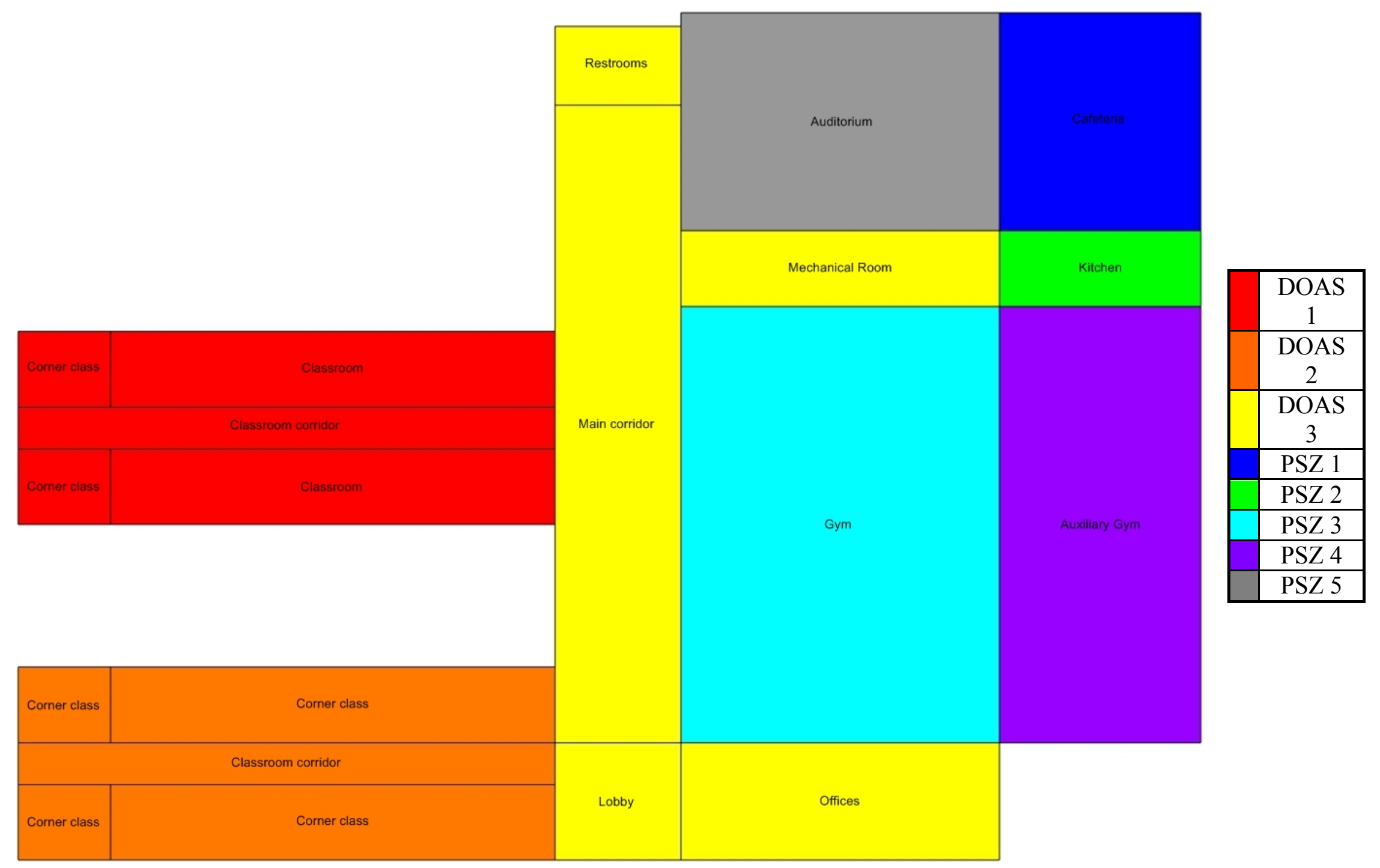

Figure 26. Secondary school HVAC layout-first floor 


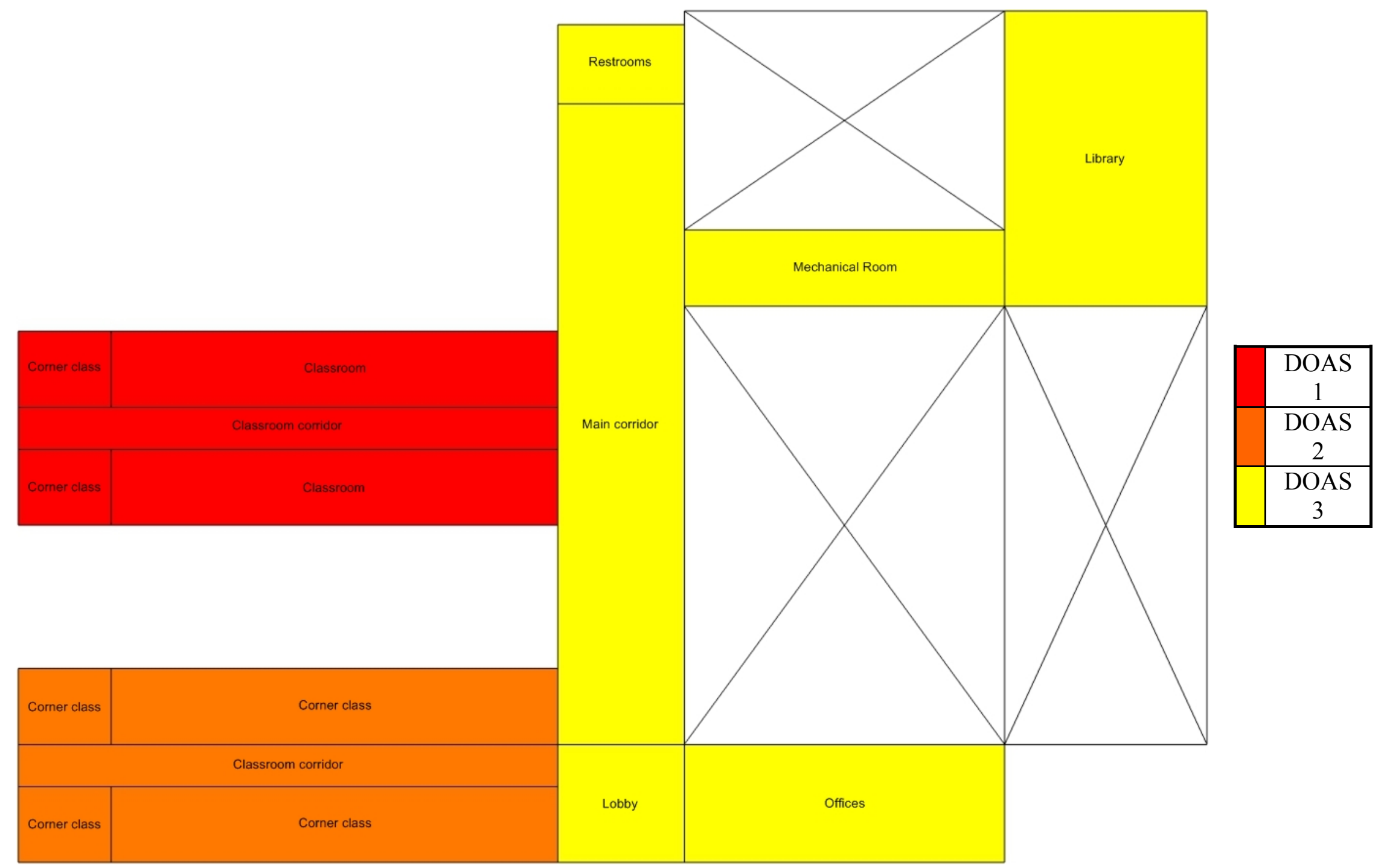

Figure 27. Secondary school HVAC layout-second floor 


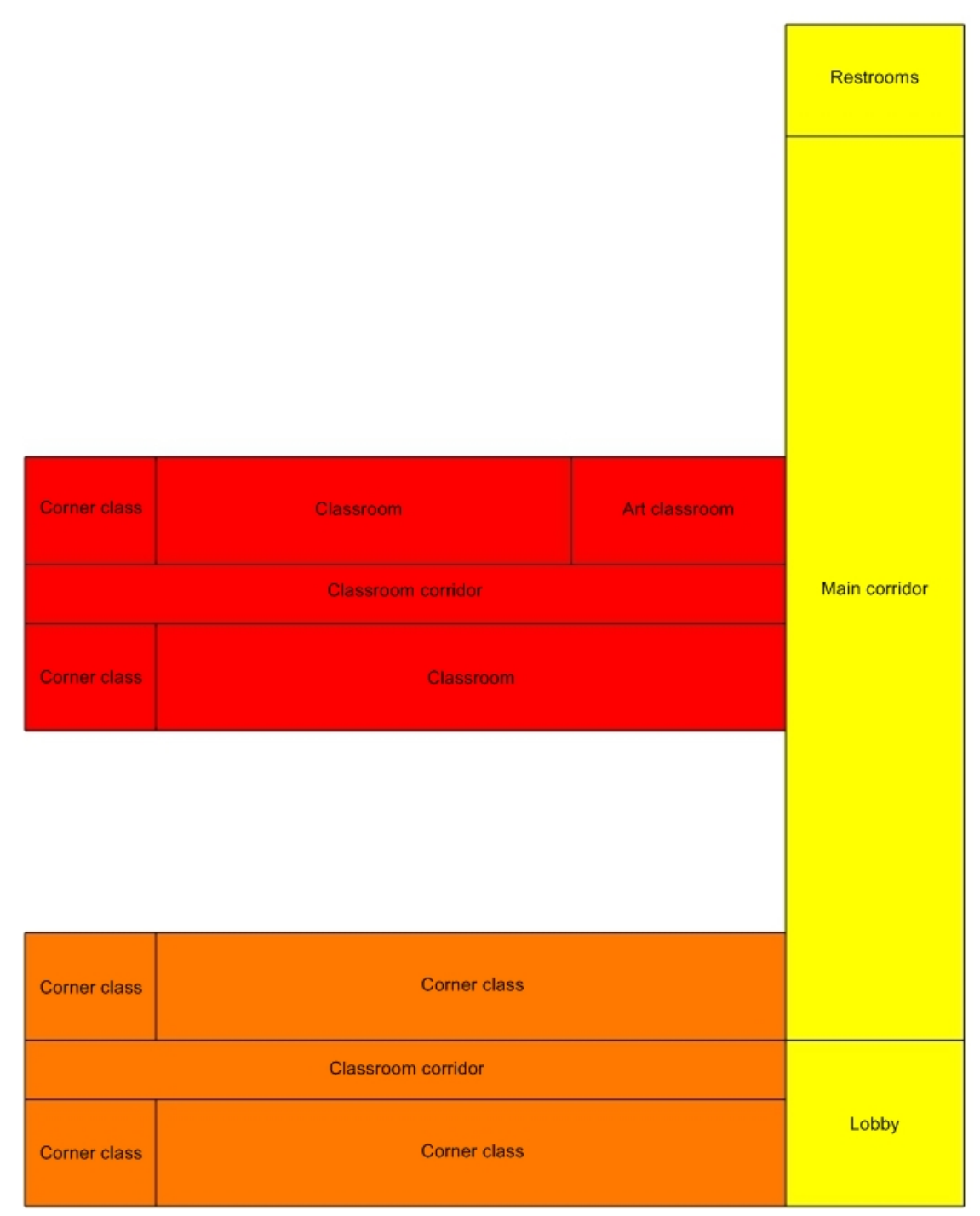

\begin{tabular}{|c|c|}
\hline DOAS \\
1 \\
\hline DOAS \\
2 \\
\hline DOAS \\
3 \\
\hline
\end{tabular}

Figure 28. Secondary school HVAC layout-third floor 
Although many types of HVAC systems could be used in $\mathrm{K}-12$ schools, this feasibility study uses a GSHP system with a DOAS for ventilation.

The HVAC zoning for the models was as follows:

- The classroom wings and most of the central common spaces were served by multizone DOASs with zone-level GSHPs. This was a central theme to the HVAC strategies; that is, the ventilation need was decoupled from the zone heating and cooling.

- The specialty spaces (auditorium, cafeteria, kitchen, and gym) were served by PSZ heat pump HVAC systems. These systems represent best-in-class efficiency, however, and they are connected to the same ground loop as the zone-level heat pumps.

\section{Ventilation and Occupancy}

Table 6-1 in Standard 62.1-2007 (ASHRAE 2007) was used to determine the ventilation requirements for the models. This standard was chosen because it is the ventilation standard referenced by Standard 90.1-2013 (ASHRAE 2013b). Table 20 shows space types in the models, their mapping to the "Occupancy Category" column in Standard 62.1-2007 Table 6-1, and the ventilation rates.

Table 20. Ventilation Rates by Space Type

\begin{tabular}{|c|c|c|c|c|}
\hline Space Type & $\begin{array}{l}\text { Occupancy Category } \\
\text { (From Table 6-1 in 62.1-2007) }\end{array}$ & $\begin{array}{l}\text { People } \\
\text { Outdoor Air } \\
\text { Rate } \\
\text { (CFM/person) }\end{array}$ & $\begin{array}{l}\text { Area } \\
\text { Outdoor } \\
\text { Air Rate } \\
\left(\text { CFM/ft' }{ }^{2}\right)\end{array}$ & $\begin{array}{l}\text { Peak } \\
\text { Occupant } \\
\text { Density } \\
(\# / 1,000 \\
\left.\mathrm{ft}^{2}\right)\end{array}$ \\
\hline Auditorium & $\begin{array}{l}\text { Educational facilities: } \\
\text { music/theater/dance }\end{array}$ & 10.0 & 0.06 & 35 \\
\hline Art room & Educational facilities: art classroom & 10.0 & 0.18 & 20 \\
\hline Cafeteria & $\begin{array}{l}\text { Food and beverage service: } \\
\text { Cafeteria/fast-food dining }\end{array}$ & 7.5 & 0.18 & 100 \\
\hline Classroom & $\begin{array}{l}\text { Educational facilities: classrooms } \\
\text { (age } 9 \text { plus) }\end{array}$ & 10.0 & 0.12 & 35 \\
\hline Corridor & General: corridors & 0.0 & 0.06 & 0 \\
\hline $\begin{array}{l}\text { Gym/multipurpose } \\
\text { room } \\
\text { Kitchen }\end{array}$ & $\begin{array}{l}\text { Educational facilities: multiuse } \\
\text { assembly } \\
\text { See Table } 19\end{array}$ & 7.5 & 0.06 & 100 \\
\hline $\begin{array}{l}\text { Library/media } \\
\text { center }\end{array}$ & Educational facilities: media center & 10.0 & 0.12 & 25 \\
\hline Lobby & General: corridors & 0.0 & 0.06 & 0 \\
\hline Mechanical & General: corridors & 0.0 & 0.06 & 0 \\
\hline Office & Office buildings: office space & 5.0 & 0.06 & 5 \\
\hline Restroom & See Table 21 & & 0.39 & \\
\hline
\end{tabular}

The peak occupant densities shown in Table 19 and Table 20 were modified by schedules in EnergyPlus. Table 21 maps each space type in the model to its occupancy schedule from schedule profiles shown in Figure 29 through Figure 39. In general, the primary and secondary schools have different schedules except for the library/media center occupancy schedule, which is the same for both models. These schedules are the same as the schedules used in Bonnema et al. (2013). Much of this data was based on actual submetered data collected from schools. 
Table 21. Occupancy Schedule Reference Matrix

\begin{tabular}{lll}
\hline \multirow{2}{*}{ Space Type } & \multicolumn{2}{c}{ Schedule } \\
\cline { 2 - 3 } & \multicolumn{1}{c}{ Primary School } & \multicolumn{1}{c}{ Secondary School } \\
\hline Auditorium & NA & Figure 38 \\
Art room & Figure 30 & Figure 30 \\
Cafeteria & Figure 31 & Figure 35 \\
Classroom & Figure 30 & Figure 34 \\
Corridor & Zero occupant density & Zero occupant density \\
Gym/multipurpose room & Figure 32 & Main gym: Figure 36 \\
Kitchen & Zero occupant density & Auxiliary gym: Figure 38 \\
Library/media center & NA & Zero occupant density \\
Lobby & Zero occupant density & Figure 29 \\
Mechanical & Zero occupant density & Zero occupant density \\
Office & Figure 33 & Zero occupant density \\
\hline Restroom & Zero occupant density & Figure 37 \\
\hline
\end{tabular}

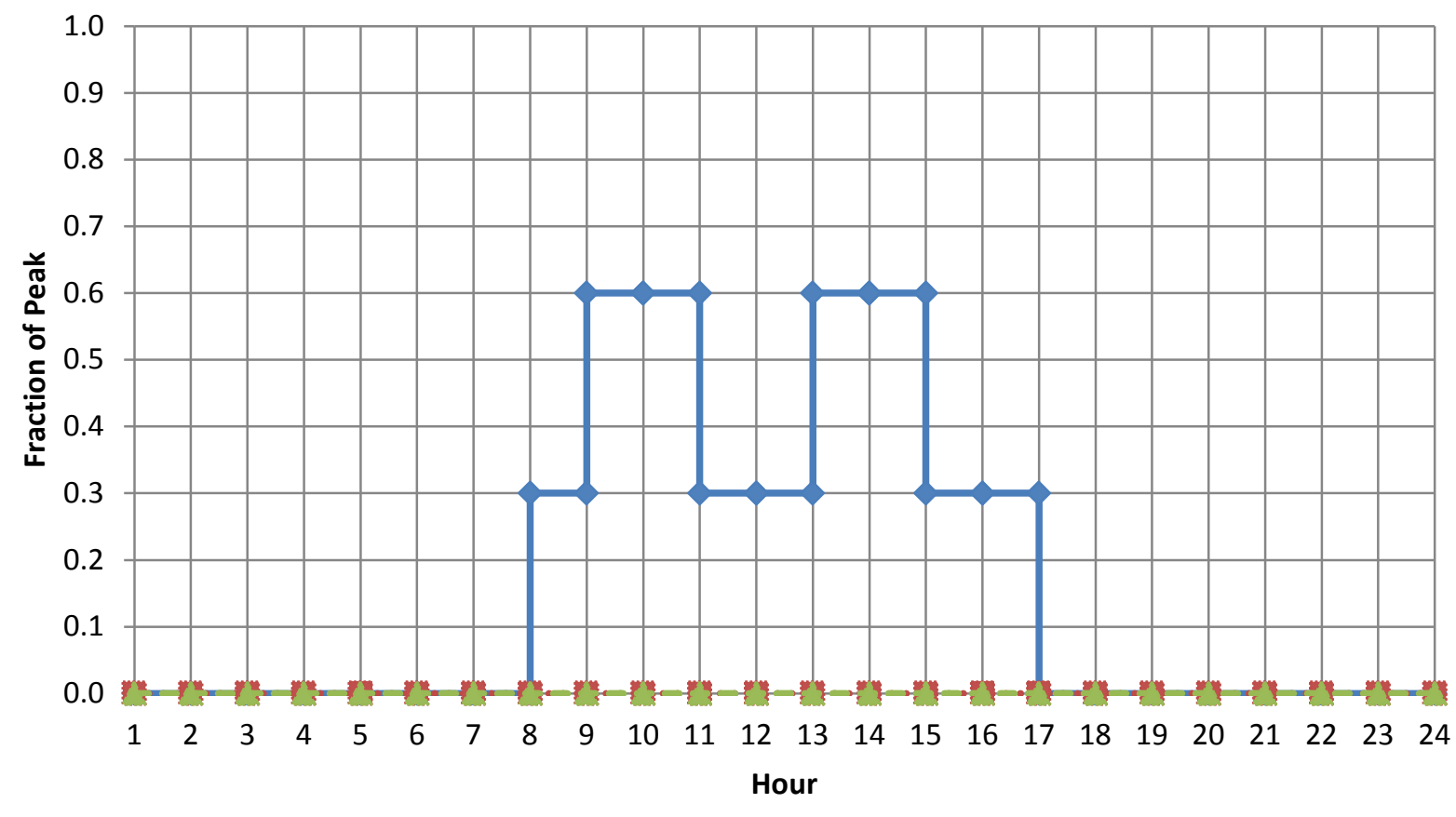

$\longrightarrow$ School Weekdays $\quad . . m$. Summer Weekdays $\quad-\rightarrow-$ Other Days

Figure 29. Library/media center occupancy schedule 


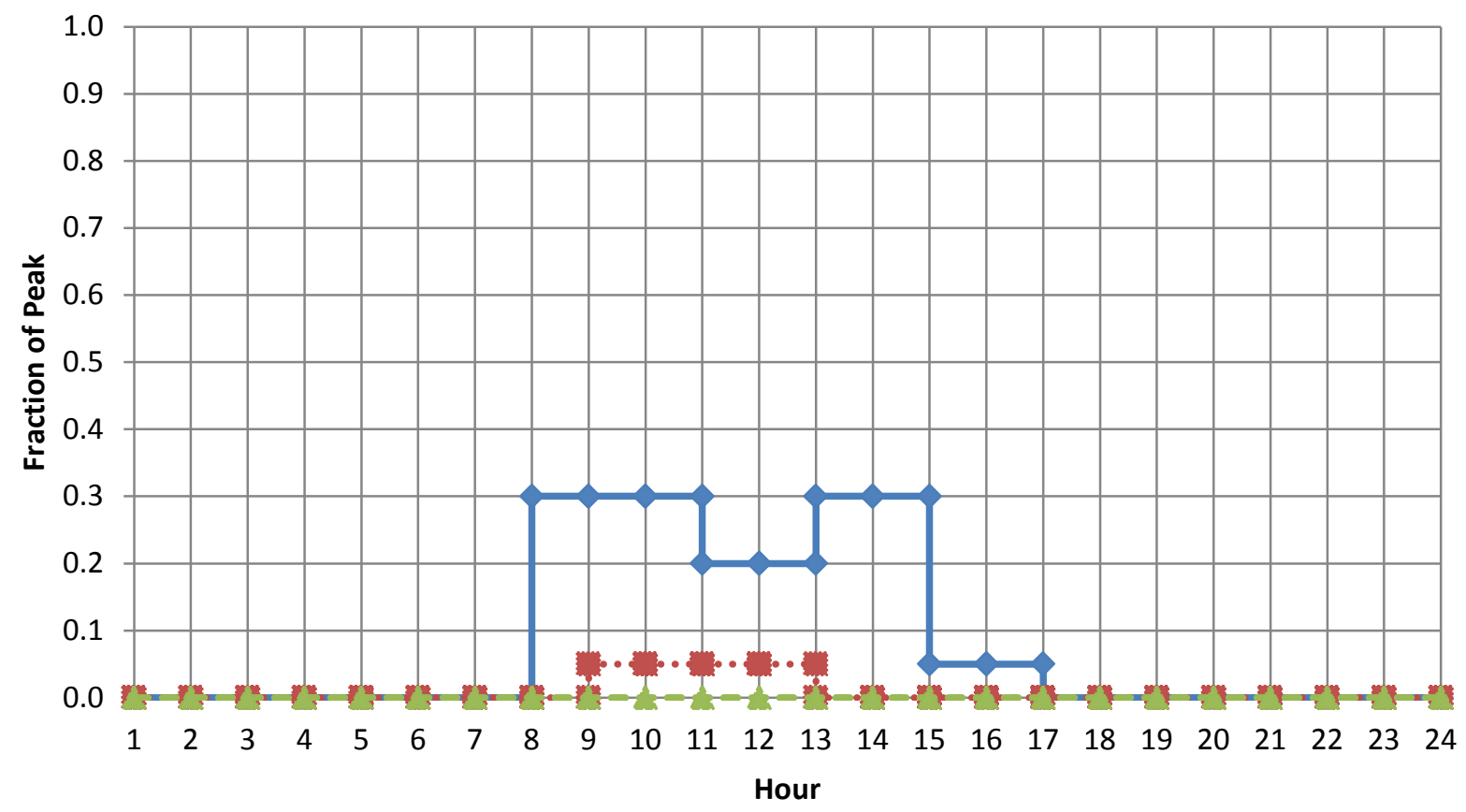

$\longrightarrow$ School Weekdays $\quad . . \cdots$ Summer Weekdays $\quad-4-$ Other Days

Figure 30. Primary school general occupancy schedule

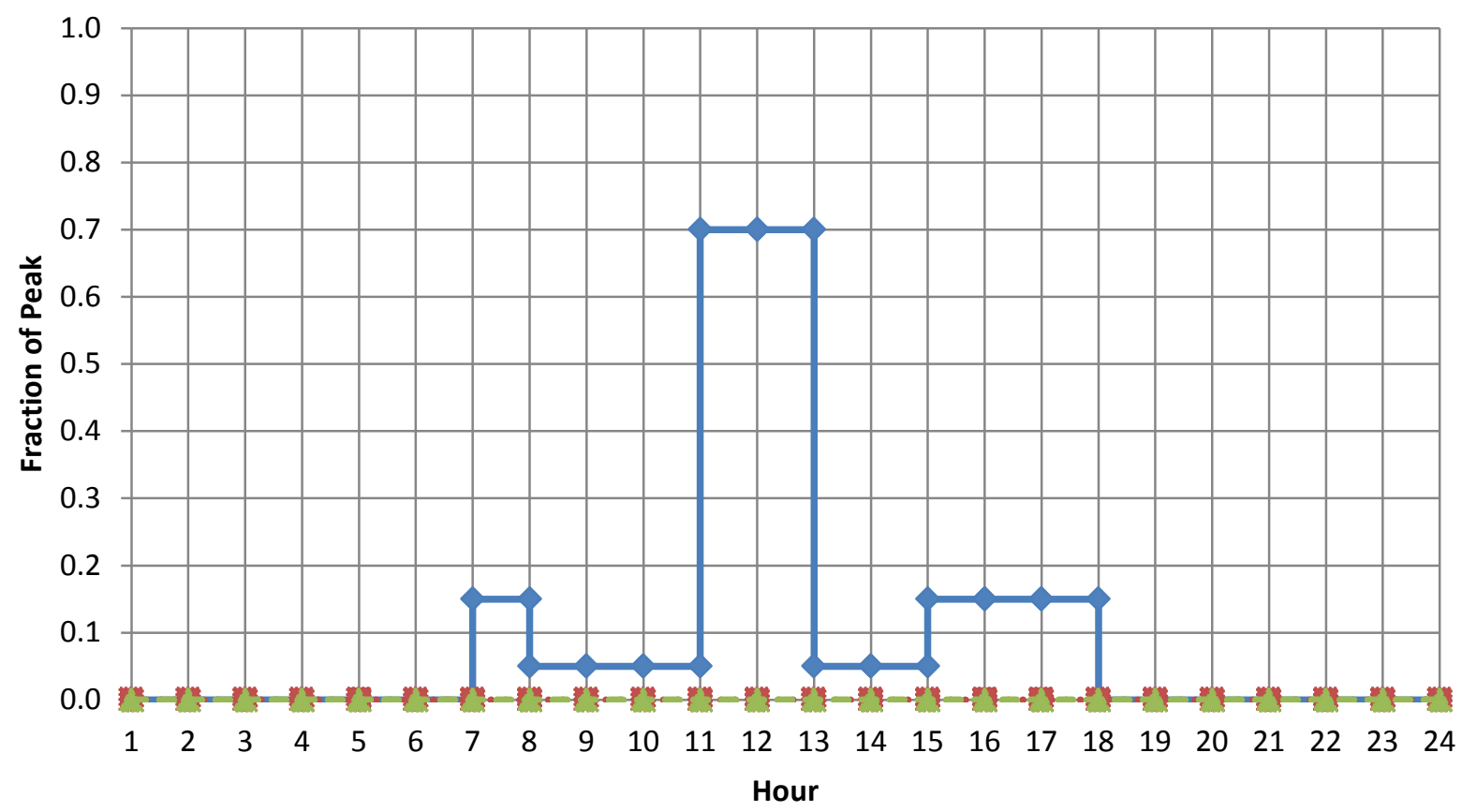

$\longrightarrow$ School Weekdays $\quad \cdots+$.u... Summer Weekdays $\quad-\rightarrow-$ Other Days

Figure 31. Primary school cafeteria occupancy schedule 


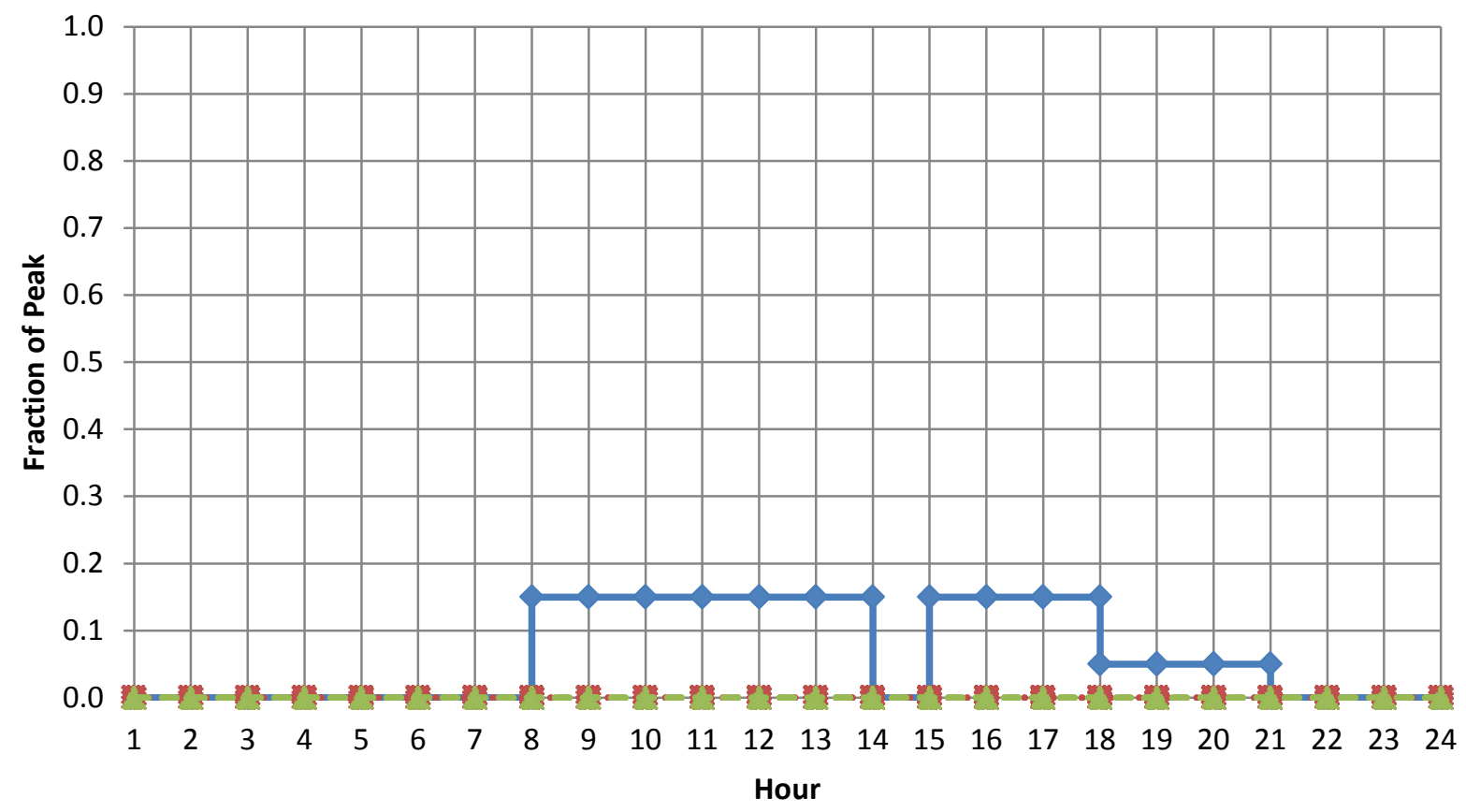

$\longrightarrow$ School Weekdays $\quad \ldots \ldots$........ Summer Weekdays $\quad-\rightarrow-$ Other Days

Figure 32. Primary school gym occupancy schedule

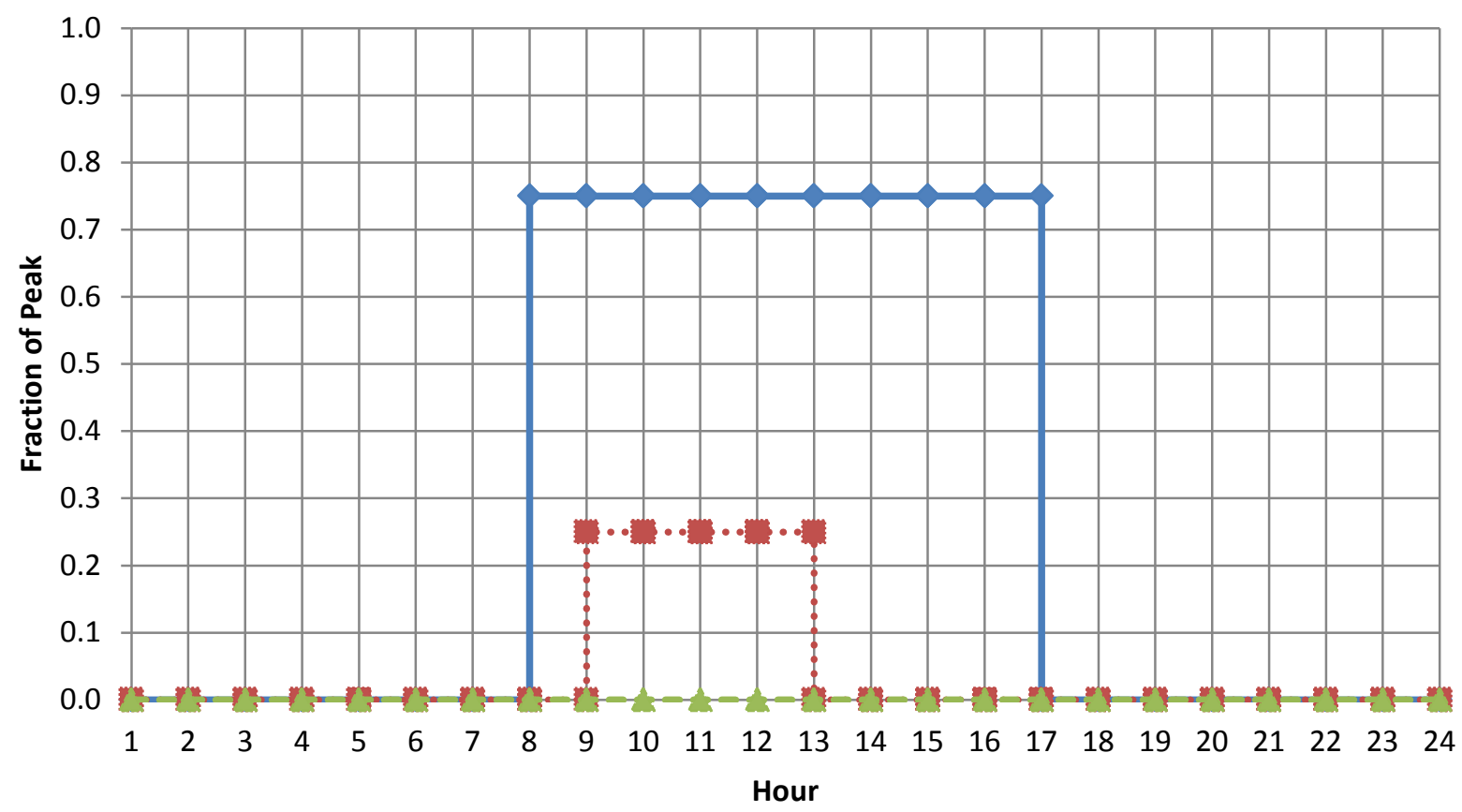

$\longrightarrow$ School Weekdays $\quad \cdots+$.u... Summer Weekdays $\quad-\rightarrow-$ Other Days

Figure 33. Primary school office occupancy schedule 


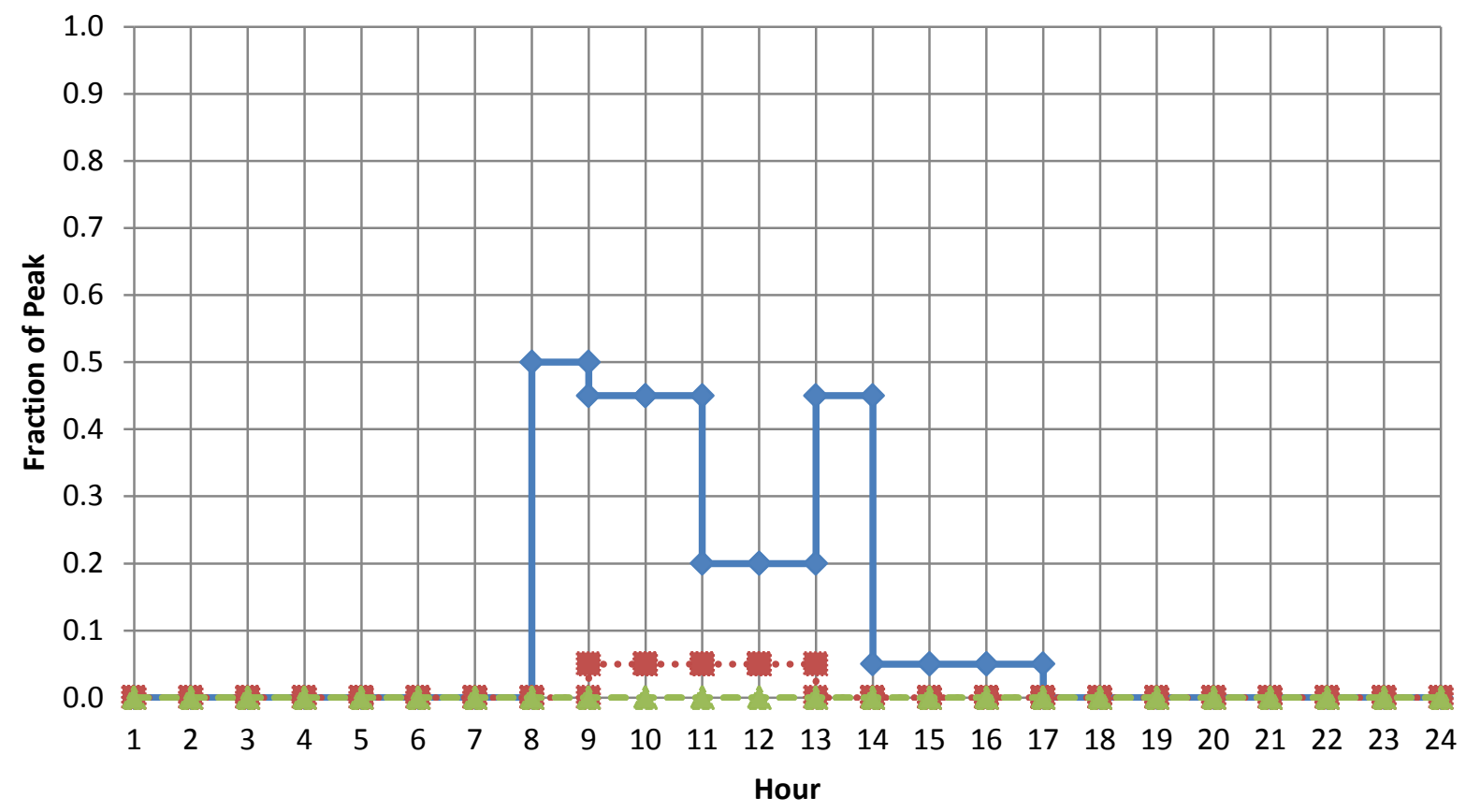

$\longrightarrow$ School Weekdays $\quad . . \cdots$ Summer Weekdays $\quad-4-$ Other Days

Figure 34. Secondary school general occupancy schedule

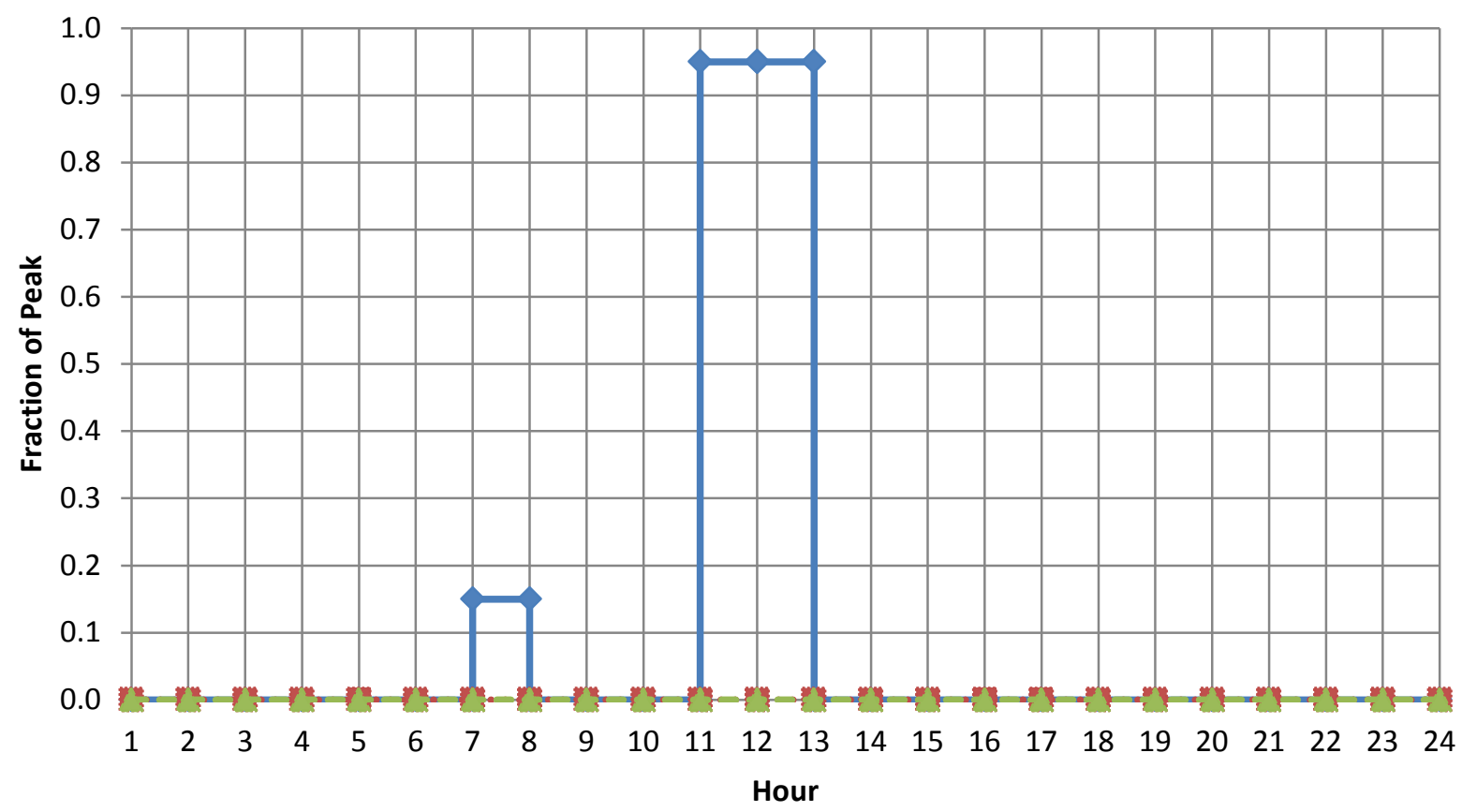

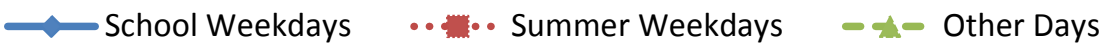

Figure 35. Secondary school cafeteria occupancy schedule 


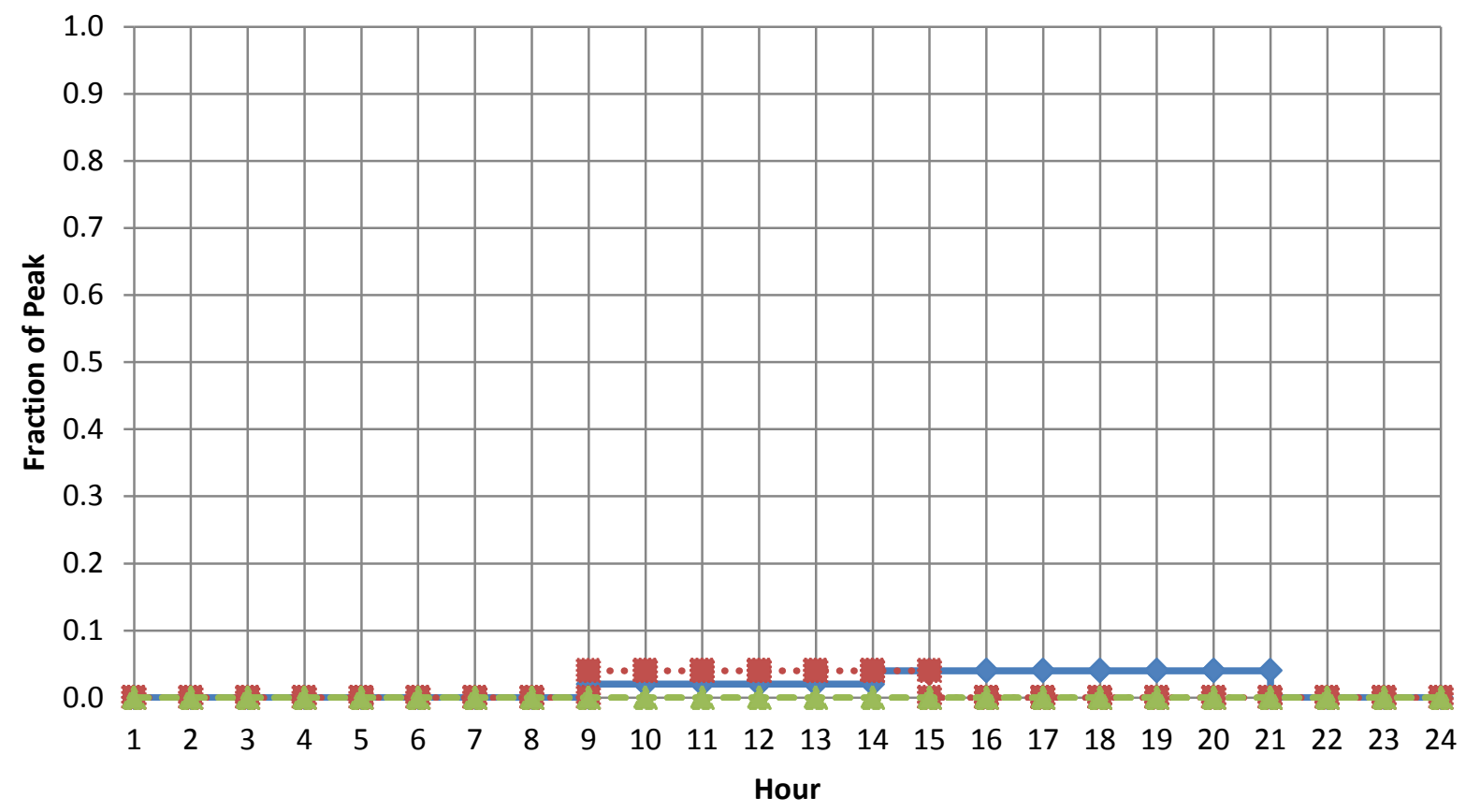

$\longrightarrow$ School Weekdays $\quad \ldots \ldots$........ Summer Weekdays $\quad-\rightarrow-$ Other Days

Figure 36. Secondary school gym occupancy schedule

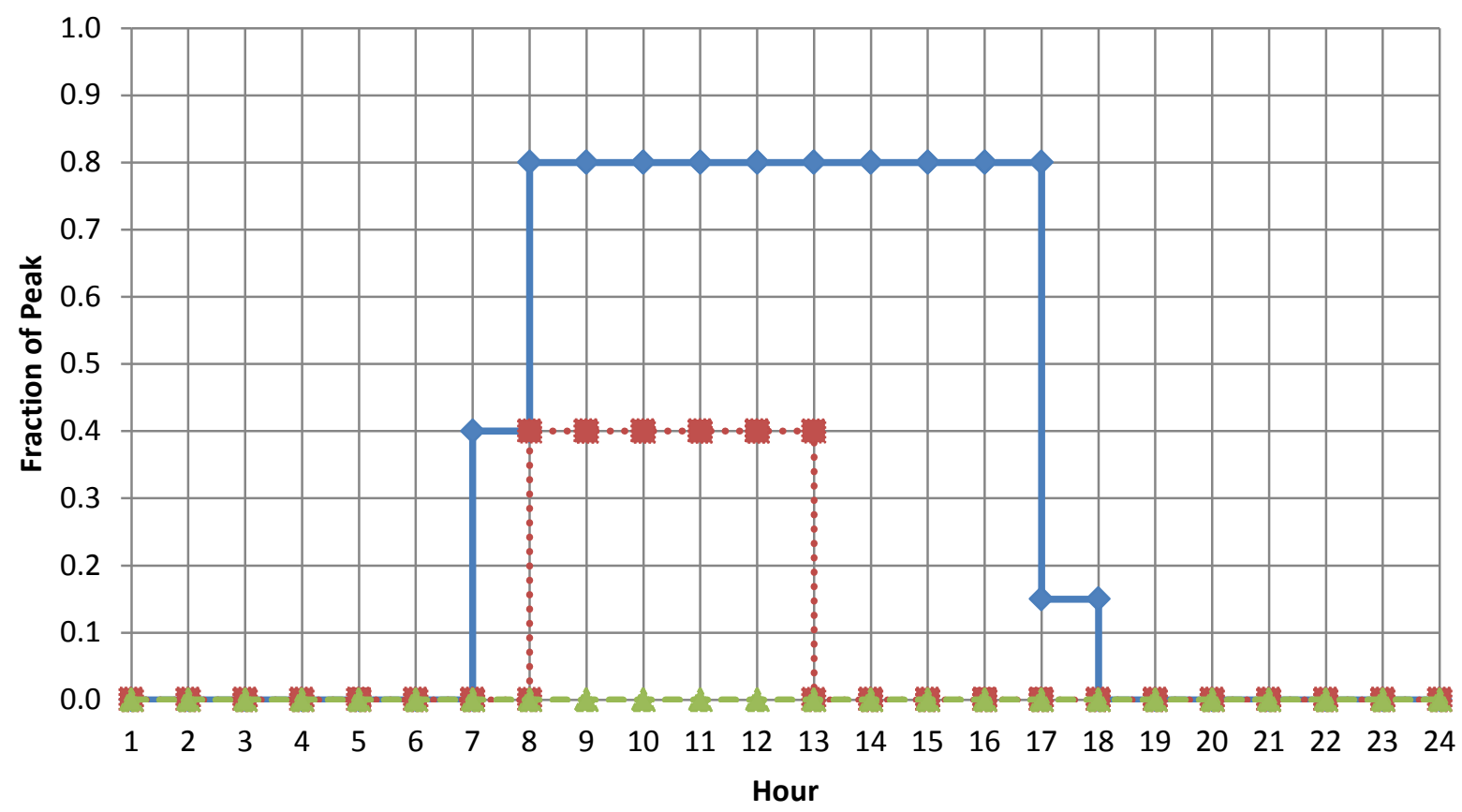

$\longrightarrow$ School Weekdays $\quad \cdots+$.u... Summer Weekdays $\quad-\rightarrow-$ Other Days

Figure 37. Secondary school office occupancy schedule 


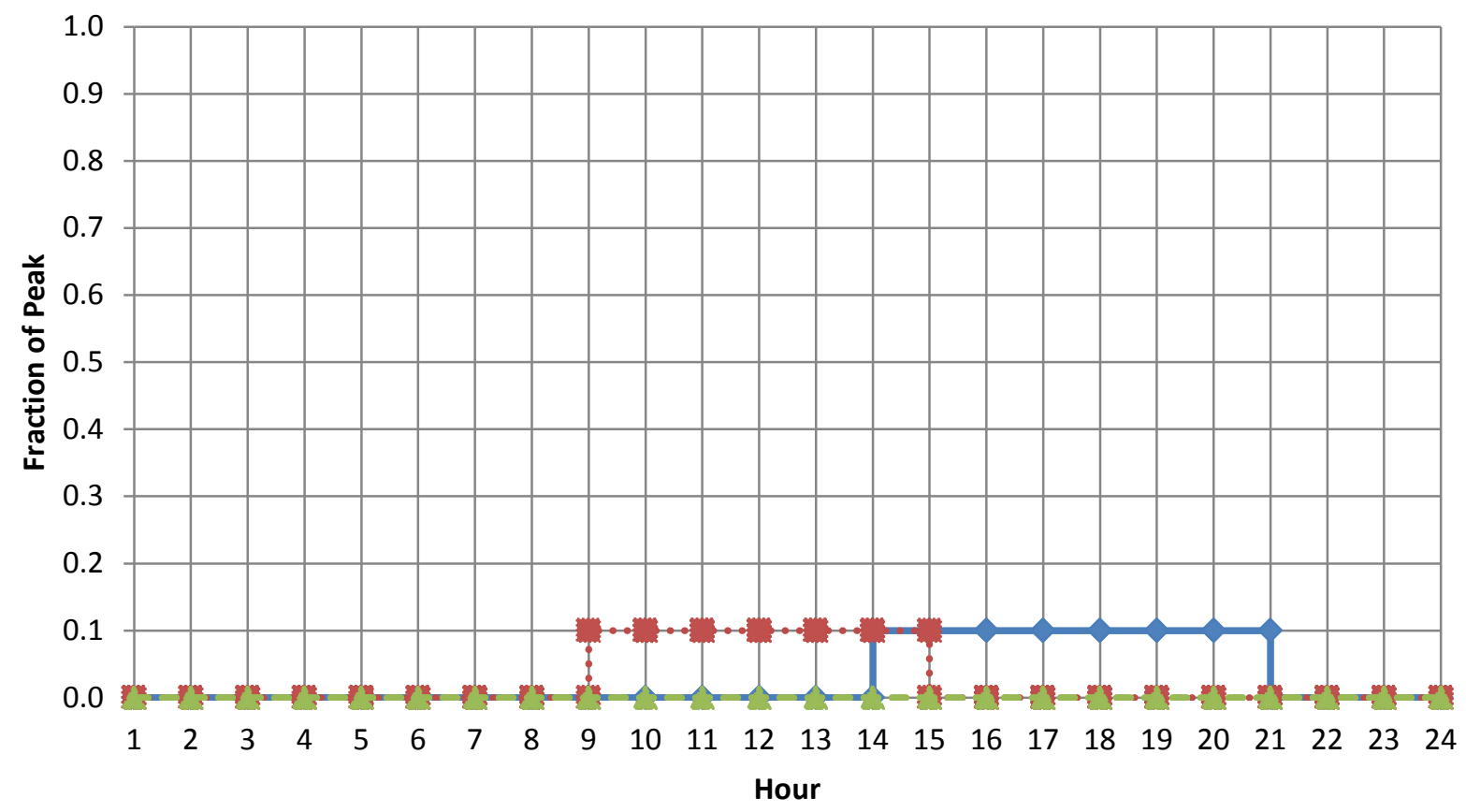

$\longrightarrow$ School Weekdays ……. Summer Weekdays $\quad-\rightarrow$ - Other Days

Figure 38. Secondary school auditorium occupancy schedule

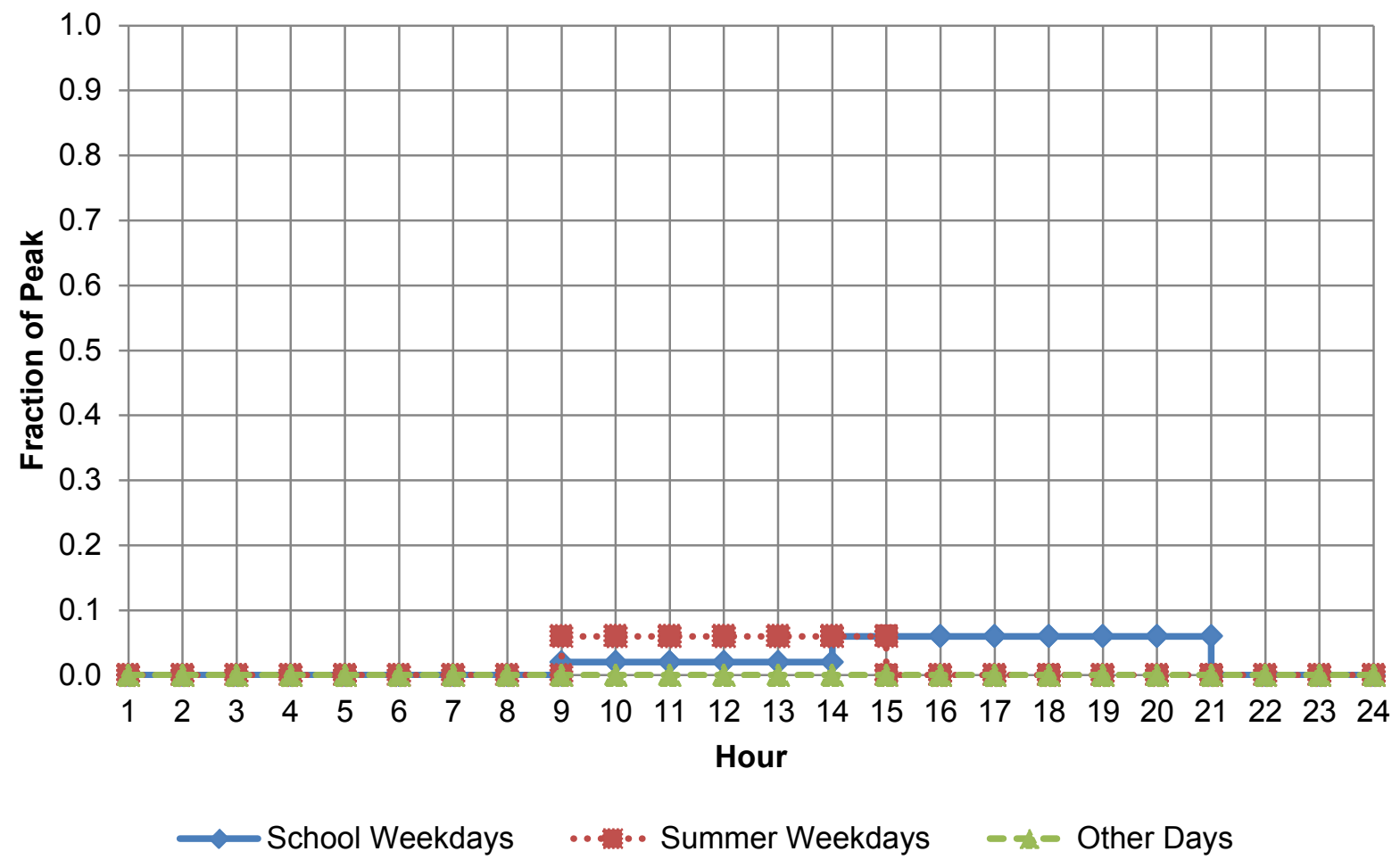

Figure 39. Secondary school auxiliary gym occupancy schedule 


\section{Thermostat Set Points}

The thermostat set points in the models were derived from those in Deru et al. (2011). Bonnema et al. (2013) modified the set points based on industry experience designing schools. The heating set point schedule is shown in Figure 40, and the cooling set point schedule is shown in Figure 41.

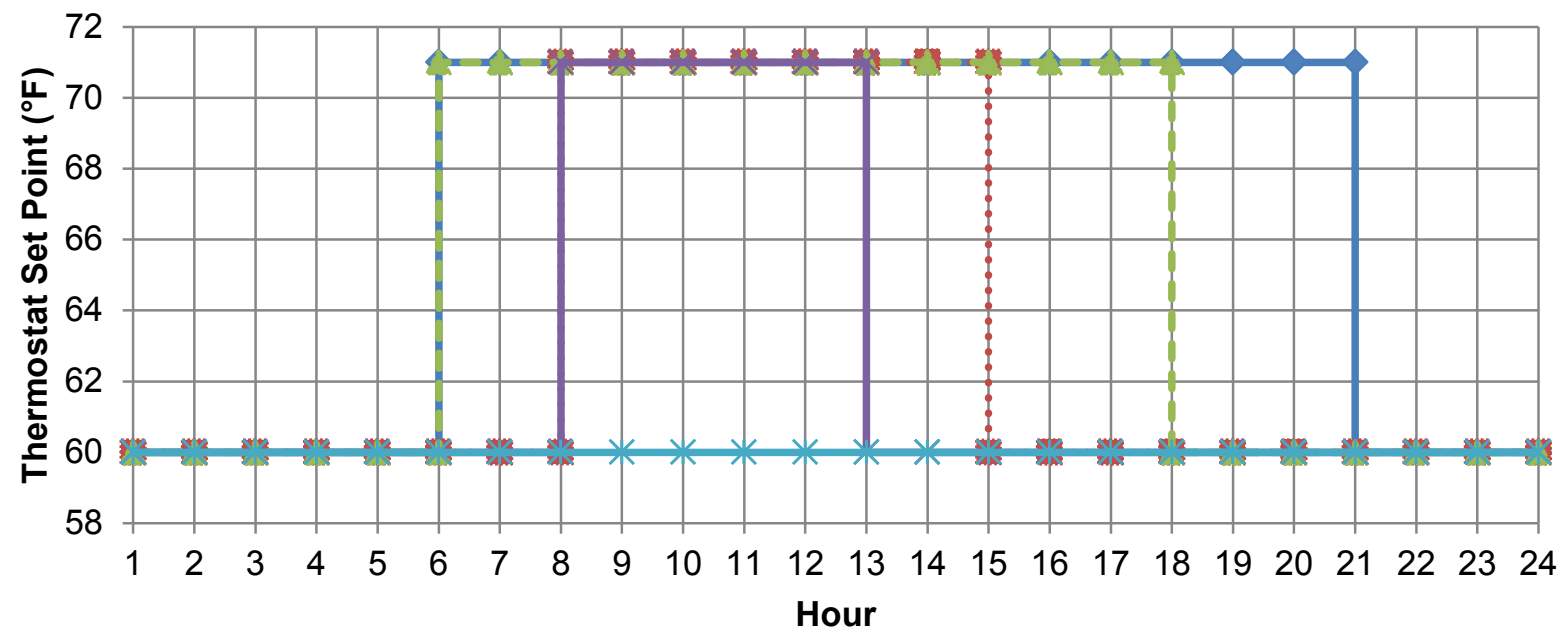

\footnotetext{
$\leadsto$ Gym/Auditorium Weekdays

...... Secondary School Gym/Auditorium Summer Weekdays

- An- School Weekdays

$\leftarrow$ Summer Weekdays

* Other Days
}

Figure 40. Heating set point schedule 

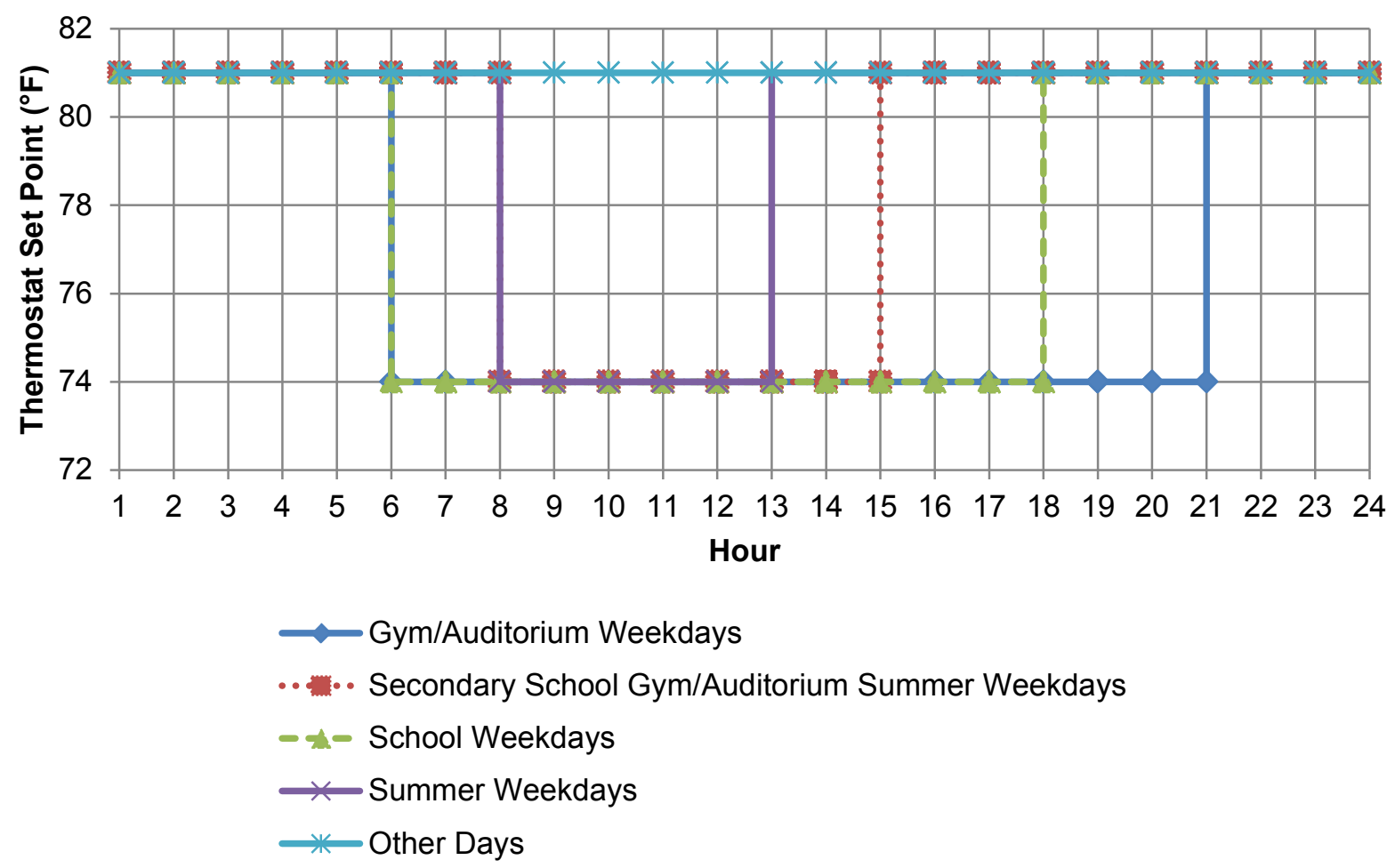

Figure 41. Cooling set point schedule

\section{Packaged Single-Zone Systems}

The primary and secondary school energy models had PSZ heat pump systems serving the auditoriums, cafeterias, gyms, and kitchens. The PSZ heat pump systems included direct expansion heat pump coils with a 19.7 cooling energy efficiency ratio (EER) and a 3.7 heating coefficient of performance (COP), $60 \%$ efficient constant air volume fans with 1-in. water column (w.c.) pressure drop, and differential enthalpy-controlled economizers. Economizers were not used in climate zones 1A, 2A, 3A, and 4A per Standard 90.1-2013 (ASHRAE 2013b). The PSZ units added energy-recovery ventilators (ERVs) in all climate zones that were modeled with a $75 \%$ sensible effectiveness, $69 \%$ latent effectiveness, and a 0.5 -in. w.c. pressure drop. The ERVs were equipped with exhaust-only frost control, with a threshold temperature of $-10^{\circ} \mathrm{F}$, an initial defrost time fraction of $0.083 \mathrm{~min} / \mathrm{min}$, and a defrost time increase rate of 0.024 $(\min / \mathrm{min}) /{ }^{\circ} \mathrm{C}$.

\section{Dedicated Outdoor Air Systems}

For most of the floor area of both the primary and secondary school models, a DOAS provides ventilation, and a GSHP provides space conditioning. The DOASs provided ventilation air for the classrooms, corridors, library/media center, lobbies, mechanical rooms, offices, and restrooms. The DOASs were modeled with a heat pump (a direct-expansion heating and cooling coil) and a VAV fan. The VAV fan had a fan efficiency of $69 \%$, a motor efficiency of $90 \%$, and a system pressure drop of 4-in. w.c. The DOAS also included ERVs. Each ERV was modeled with a $75 \%$ sensible effectiveness, $69 \%$ latent effectiveness, and a 0.5 -in. w.c. pressure drop. The ERVs were equipped with exhaust-only frost control, with a threshold temperature of $-10^{\circ} \mathrm{F}$, an initial defrost time fraction of $0.083 \mathrm{~min} / \mathrm{min}$, and a defrost time increase rate of 0.024 
$(\mathrm{min} / \mathrm{min}) /{ }^{\circ} \mathrm{C}$. The heat pump had a cooling EER of 19.7 and a heating COP of 3.7. The ventilation air from the DOAS was delivered to the zone via a VAV terminal unit that was capable of varying the ventilation rate. Figure 42 shows the DOAS configuration for the GSHP HVAC system configuration.

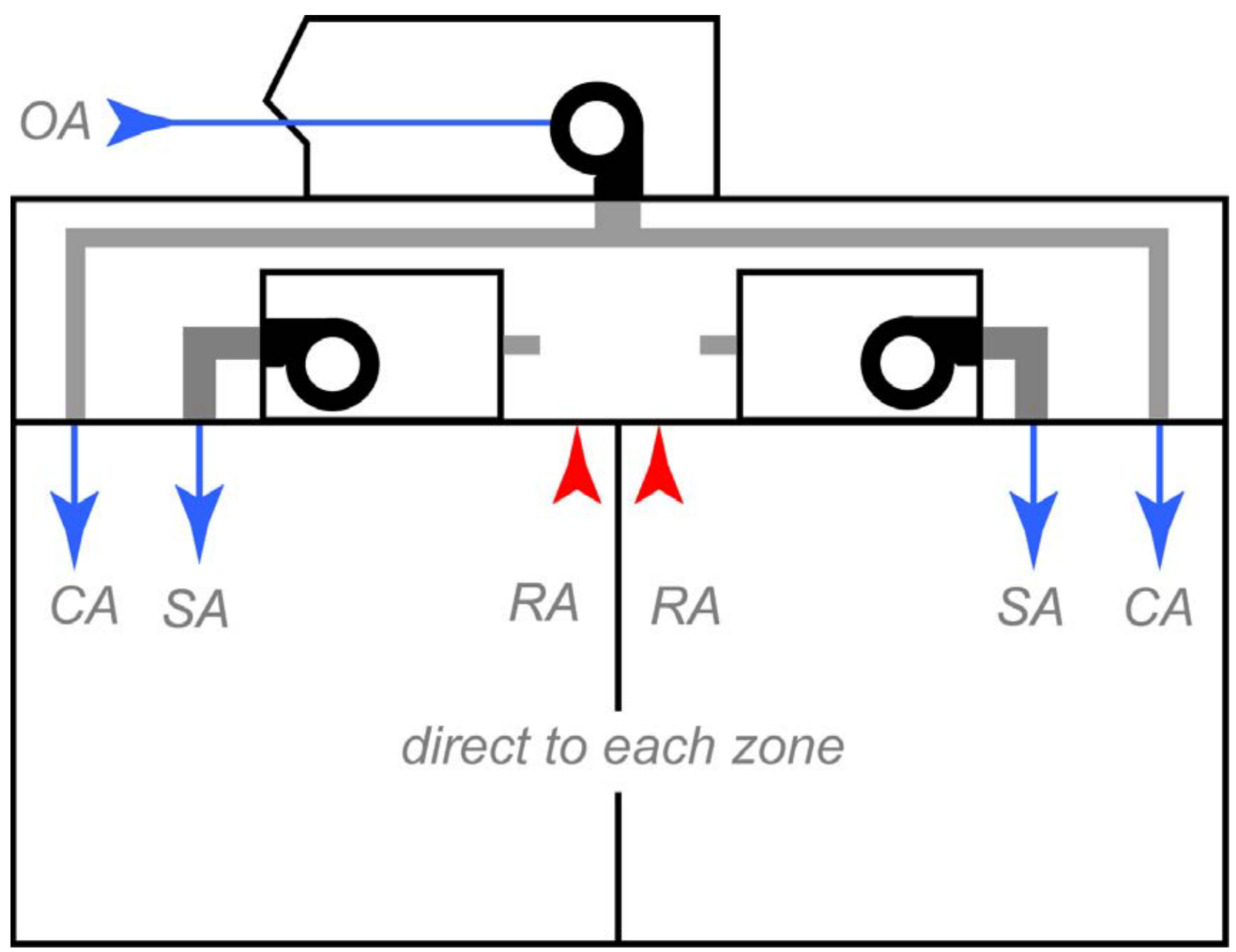

Figure 42. DOAS configuration for GSHP system.

Image from ASHRAE 2012.

\section{Ground Source Heat Pump System}

Each zone served by the DOAS (classrooms, corridors, library/media center, lobbies, mechanical rooms, offices, and restrooms) were also modeled with a two-speed GSHP. The primary school had 22 separate heat pumps; the secondary school had 42. The heat pumps represented best-inclass efficiency levels, with a cooling EER of 19.7, a heating COP of 3.7, and 50\% efficient constant-speed fans that cycled with the load (0.25-in. w.c. pressure drop).

The heat pumps rejected energy to a single plant loop that was served by a $90 \%$ efficient variable-speed pump with $400 \mathrm{ft}$ of head and a loop temperature set point of $69.8^{\circ} \mathrm{F}$. A ground heat exchanger was modeled using the EnergyPlus Runtime Language. The EnergyPlus Runtime Language program raised the temperature of the loop $10^{\circ} \mathrm{F}$ if the entering water temperature was lower than $60^{\circ} \mathrm{F}$, and it lowered the temperature of the loop $10^{\circ} \mathrm{F}$ if the entering water 
temperature was higher than $60^{\circ} \mathrm{F}$. The heat-rejection loop included a boiler to help maintain loop temperature during the winter. The boiler on the loop was a $90 \%$ efficient natural gas-fired condensing boiler.

In climates where building heating and cooling loads are severely imbalanced, the borefield ground temperature can drift away from its equilibrium point during a period of many years, hindering the ability of the system to operate at its designed efficiency. Besides the building thermal loads rejected/extracted to/from the ground, many site-specific factors can affect the ground's response to the GSHP system, including the thermal conductivity, thermal diffusivity, and hygrodynamic properties of the soil (including the presence or absence of groundwater at the well depth). These factors can vary considerably over short distances and should be taken into account when designing the system-specific borefield.

Many steps can be taken during system design to mitigate long-term temperature drift and/or its impact on the operation of the GSHP system, including upsizing the borefield (although this will obviously increase the system cost) or coupling a heating or cooling source to the GSHP loop. Given the large number of practical design solutions available, and given the successful deployment of GSHP systems in extremely cold climates (Meyer et al. 2011), the use of GSHP systems for this study was deemed appropriate for evaluating the ability to achieve zero energy in the school environment.

\subsection{Service Water Heating}

Both the primary school and secondary school models had a $90 \%$ efficient natural gas-fired storage tank water heater, and the secondary school had a $90 \%$ efficient variable-speed circulation pump with $13.1 \mathrm{ft}$ of head. The primary school had no circulation pump. The primary school model had water use in the restrooms and kitchen; the restrooms had a peak flow rate of $0.942 \mathrm{gal} / \mathrm{min}$, and the kitchen had a peak flow rate of $1.667 \mathrm{gal} / \mathrm{min}$. The secondary school had water use in the restrooms, kitchen, and gym (showers); the restrooms had a peak flow rate of $0.870 \mathrm{gal} / \mathrm{min}$, the kitchen had a peak flow rate of $2.217 \mathrm{gal} / \mathrm{min}$, and the gym (showers) had a peak flow rate of $3.158 \mathrm{gal} / \mathrm{min}$. (See Deru et al. [2011] for more information on how these values were determined.) The peak flow rates for the restroom and kitchen zones in both models were modified by the schedule shown in Figure 43. The peak flow rates for the showers in the secondary school gym were modified by the schedule shown in Figure 44. 


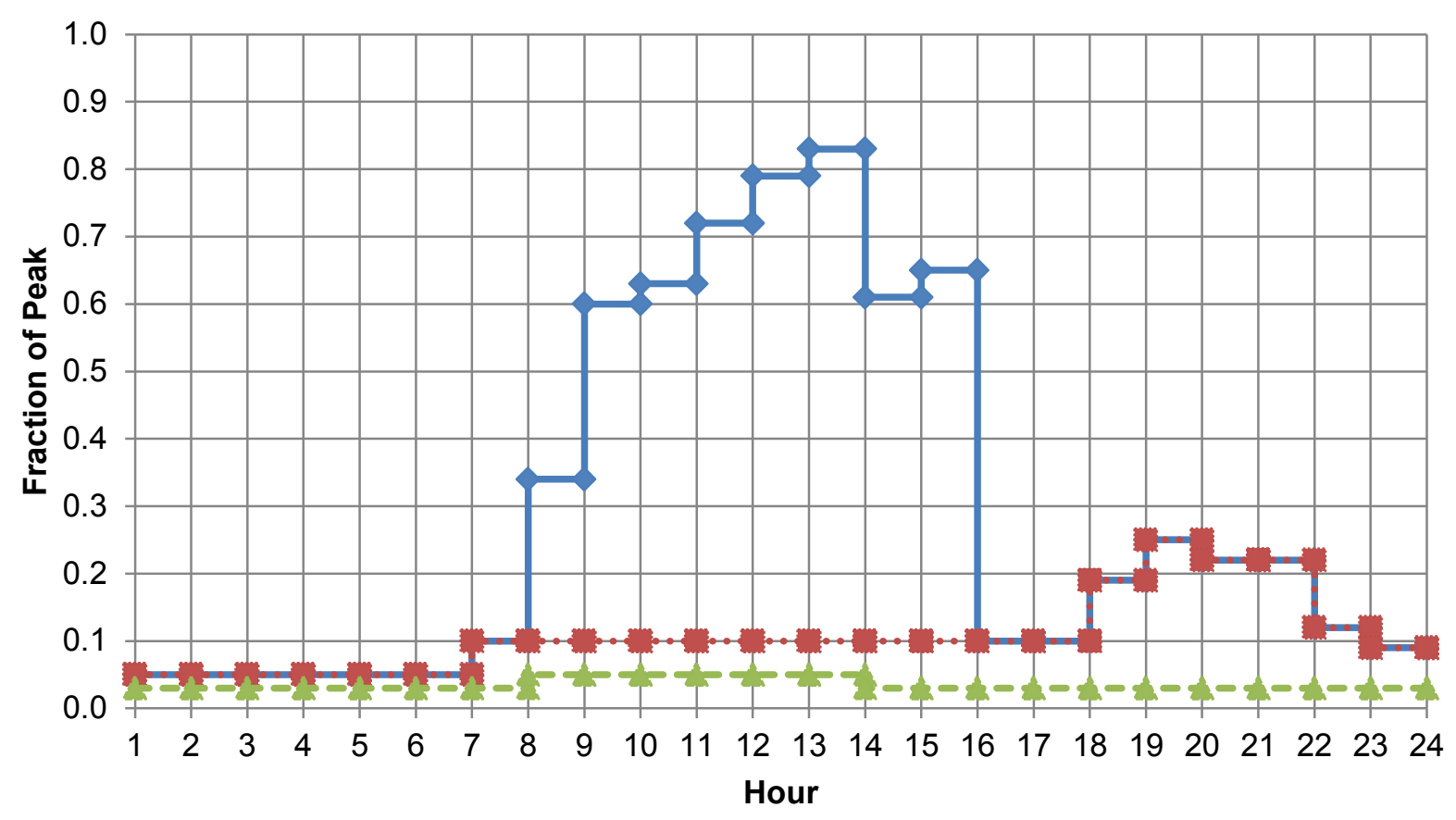

$\longrightarrow$ School Weekdays $\quad$ …. Summer Weekdays $\quad-\rightarrow-$ Other Days

Figure 43. General SWH schedule

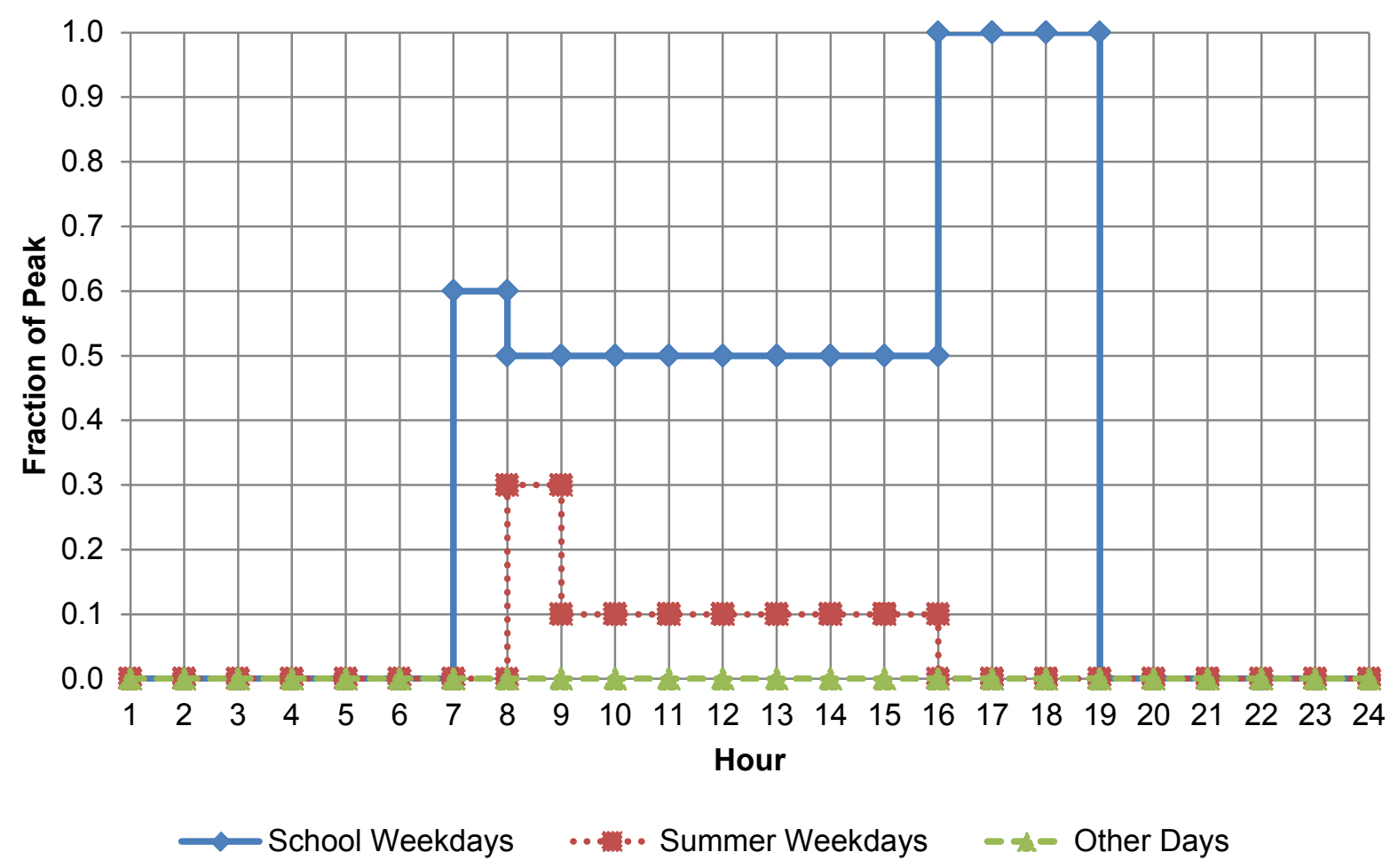

Figure 44. Secondary school shower SWH schedule 


\section{Refrigeration}

Each school has a walk-in cooler and freezer; the equipment in the secondary school is twice as large as that in the primary school. Table 22 shows an overview of the refrigeration equipment in the models. (See Deru et al. [2011] for more information on the refrigeration equipment in the models.) The full EnergyPlus input data file refrigeration objects can be found in Appendix B.

Table 22. Refrigeration Models

\begin{tabular}{|c|c|c|c|}
\hline Model & Case Type & $\begin{array}{l}\text { Walk-in Area } \\
\left(\mathrm{ft}^{2}\right)\end{array}$ & $\begin{array}{l}\text { Operating Temperature } \\
\left({ }^{\circ} \mathrm{F}\right)\end{array}$ \\
\hline \multirow{2}{*}{ Primary school } & Walk-in freezer & 120 & -9.4 \\
\hline & Walk-in cooler & 120 & 35.6 \\
\hline \multirow{2}{*}{ Secondary school } & Walk-in freezer & 240 & -9.4 \\
\hline & Walk-in cooler & 240 & 35.6 \\
\hline
\end{tabular}

\section{Workflow Enhancements}

During the course of this project, three OpenStudio feature additions were identified that, if realized, would enable more convenient ZEB design analysis. Once implemented, these would also allow for more comprehensive analysis and ultimately provide more market-relevant energy conservation measures and strategies to be included in a zero energy design guidance document.

1. Holiday schedules. OpenStudio's schedule development capability allows users to quickly create complex schedules. Particularly powerful is the OpenStudio App schedule development graphical user interface, which allows users to quickly define and apply numerous "periods" within the same schedule (e.g., applying summer break profiles to the occupancy and lighting schedules); however, schedules developed with OpenStudio do not recognize holiday periods. The implication for the models in this study was that the schools were occupied/operational during regularly observed weekday holidays, such as Martin Luther King Jr. Day and Columbus Day. Adding holiday support to OpenStudio's schedule generation tool would result in slightly lower EUIs for the models examined because during those days the buildings would operate in a less energyintensive state (setback/setup mode with reduced outdoor air requirements and reduced lighting/equipment loads).

2. Demand controlled ventilation. Demand controlled ventilation (DCV) capabilities are implemented within EnergyPlus, allowing the use of DCV with both recirculation systems and DOAS; however, the systems themselves must be constructed in a very specific manner to allow the DCV controls to function as intended. When pairing DCV capability with a DOAS system, this means that only one specific terminal unit can be used. That terminal unit is not yet supported by OpenStudio, although it is scheduled to be added in the near future. The consequence of this is that the next-best terminal unit option, which was used for these models, overventilates the space. As such, the models bring in more outdoor air than necessary, causing an excess of heating, cooling, and fan energy (the DOAS fans are sized based on the aggregate ventilation rates for each zone served by the system). Again, this implies that the results of this study are conservative because the heating, cooling, and fan EUIs would be expected to decline with the use of the forthcoming terminal unit. 
3. GLHEPro integration. Improved convenience for ZEB design analysis will likely increase the uptake of ZEB practices and strategies. K-12 ZEBs commonly rely on GSHPs to achieve design performance, so enhancing the integration of OpenStudio with GLHEPro, a popular design tool for ground source bore holes and fields, would accelerate ZEB design and construction. The OpenStudio team has taken initial steps to develop an OpenStudio/GLHEPro workflow, but additional efforts are needed to more tightly integrate the tools and reduce analysis time. The most notable improvement would be to enable a designer to use their copy of GLHEPro directly from within OpenStudio for normal GSHP design cases. This OpenStudio feature addition would expose relevant inputs and feed them to GLHEPro behind the scenes, likely using an input file and a system call. GLHEPro would then feed those results back to OpenStudio without the user ever having to leave the OpenStudio interface. This capability would greatly improve the ability to evaluate the site- and building-specific performance of GSHP systems, an effective strategy for achieving ZEB schools. 


\section{Energy Targets}

Careful goal setting is required to design and construct high-performance buildings. The goal of this feasibility study was a zero energy $\mathrm{K}-12$ school building. To better define this goal, an absolute whole-building energy target was set as a best practice. This target is a single number that defines a building's energy performance - the lower the number, the more energy efficient the building. This feasibility study provides these targets to help users set goals for their building designs. These targets can be used to:

- Select design teams as part of a procurement strategy

- Set early design goals

- Track the design development progress

- Help designers and owners ensure that the desired level of performance is achieved.

The energy targets in this feasibility study are applicable to most K-12 schools with typical programs and use profiles. The energy targets in this study were developed to simplify the process of setting whole-building absolute energy use targets.

Although the modeling provides a path to achieving the EUI, many trade-offs and technologies can be used. These strategies will change as technology improves. Specifying whole-building absolute energy use targets gives an owner and design team the freedom to reach the performance goal with an approach that best fits the project's overall goals and constraints that are not related to energy performance. It is possible to specify an absolute energy target using the energy target tables in this feasibility study and then focus analysis efforts toward achieving industry best-practice energy performance rather than on trying to define a reference point against which to measure performance. For a more detailed discussion, see Leach et al. (2012).

The whole-building absolute energy targets for this feasibility study were developed in accordance with the following approach:

1. Start with the primary and secondary school DOE prototype building models (DOE 2014).

2. Update the models according to the strategies in this feasibility study, as defined in Section 2.2 of this report.

3. Simulate the zero energy models among a set of 15 climate zones that fully represent the variations in the seven DOE continental U.S. climate zones (Figure 2).

4. Ensure that the results of the energy modeling analysis are energy targets that will meet or exceed the goal of zero energy.

The outcomes of this process are shown in Table 23 through Table 26. The results in these tables represent ZEBs expressed both in site and source metrics. 
Table 23. Primary School Site Energy Targets

\begin{tabular}{|c|c|c|c|c|}
\hline $\begin{array}{l}\text { Climate } \\
\text { Zone }\end{array}$ & $\begin{array}{c}\text { Plug/Process } \\
\text { (kBtu/ft' } \cdot \mathbf{y r})\end{array}$ & $\begin{array}{c}\text { Lighting } \\
\left(\text { kBtu/ft' }^{2} \cdot y r\right)\end{array}$ & $\begin{array}{c}\text { HVAC } \\
\left(k B t u / \mathrm{ft}^{2} \cdot \mathrm{yr}\right)\end{array}$ & $\begin{array}{c}\text { Total } \\
\left(\mathrm{kBtu} / \mathrm{ft}^{2} \cdot \mathrm{yr}\right)\end{array}$ \\
\hline $1 \mathrm{~A}$ & 11.3 & 5.3 & 9.2 & 25.9 \\
\hline $2 \mathrm{~A}$ & 11.5 & 5.3 & 7.5 & 24.3 \\
\hline $2 B$ & 11.4 & 5.3 & 7.9 & 24.7 \\
\hline $3 A$ & 11.6 & 5.3 & 6.9 & 23.8 \\
\hline $3 B$ & 11.6 & 5.3 & 6.5 & 23.4 \\
\hline $3 C$ & 11.6 & 5.3 & 4.7 & 21.6 \\
\hline $4 \mathrm{~A}$ & 11.7 & 5.3 & 6.4 & 23.5 \\
\hline 4B & 11.7 & 5.3 & 6.1 & 23.1 \\
\hline $4 C$ & 11.7 & 5.3 & 5.4 & 22.4 \\
\hline $5 \mathrm{~A}$ & 11.9 & 5.3 & 7.1 & 24.3 \\
\hline $5 B$ & 11.8 & 5.3 & 6.1 & 23.2 \\
\hline $6 \mathrm{~A}$ & 12.0 & 5.3 & 7.2 & 24.5 \\
\hline $6 B$ & 12.0 & 5.3 & 6.2 & 23.5 \\
\hline 7 & 12.1 & 5.3 & 8.4 & 25.9 \\
\hline 8 & 12.3 & 5.3 & 11.0 & 28.7 \\
\hline
\end{tabular}

Table 24. Secondary School Site Energy Targets

\begin{tabular}{|c|c|c|c|c|}
\hline $\begin{array}{l}\text { Climate } \\
\text { Zone }\end{array}$ & $\begin{array}{l}\text { Plug/Process } \\
\text { (kBtu/ft't } \cdot \mathrm{yr})\end{array}$ & $\begin{array}{c}\text { Lighting } \\
\left(\mathbf{k B t u} / \mathrm{ft}^{2} \cdot \mathrm{yr}\right)\end{array}$ & $\begin{array}{c}\text { HVAC } \\
\left(k B t u / \mathrm{ft}^{2} \cdot \mathrm{yr}\right)\end{array}$ & $\begin{array}{c}\text { Total } \\
\left(\mathrm{kBtu} / \mathrm{ft}^{2} \cdot \mathrm{yr}\right)\end{array}$ \\
\hline $1 \mathrm{~A}$ & 8.4 & 6.2 & 8.5 & 23.1 \\
\hline $2 A$ & 8.6 & 6.2 & 6.9 & 21.7 \\
\hline $2 B$ & 8.5 & 6.2 & 7.1 & 21.9 \\
\hline $3 A$ & 8.8 & 6.2 & 6.2 & 21.2 \\
\hline $3 B$ & 8.7 & 6.2 & 5.8 & 20.7 \\
\hline $3 C$ & 8.9 & 6.2 & 3.9 & 19.0 \\
\hline $4 \mathrm{~A}$ & 9.0 & 6.2 & 5.7 & 20.9 \\
\hline $4 B$ & 8.9 & 6.2 & 5.3 & 20.4 \\
\hline $4 C$ & 9.0 & 6.2 & 4.5 & 19.7 \\
\hline $5 A$ & 9.1 & 6.2 & 6.3 & 21.6 \\
\hline $5 B$ & 9.1 & 6.2 & 5.1 & 20.4 \\
\hline $6 \mathrm{~A}$ & 9.2 & 6.2 & 6.2 & 21.6 \\
\hline $6 B$ & 9.3 & 6.2 & 5.1 & 20.5 \\
\hline 7 & 9.4 & 6.2 & 7.2 & 22.8 \\
\hline 8 & 9.6 & 6.3 & 9.1 & 25.0 \\
\hline
\end{tabular}


Table 25. Primary School Source Energy Targets

\begin{tabular}{lcccc}
\hline $\begin{array}{l}\text { Climate } \\
\text { Zone }\end{array}$ & $\begin{array}{c}\text { Plug/Process } \\
\text { (kBtu/ft' } \mathbf{y r})\end{array}$ & $\begin{array}{c}\text { Lighting } \\
\left(\mathbf{k B t u} / \mathbf{f t}^{\mathbf{2}} \cdot \mathbf{y r} \mathbf{r}\right)\end{array}$ & $\begin{array}{c}\text { HVAC } \\
\left(\mathbf{k B t u} / \mathbf{f t}^{\mathbf{2}} \cdot \mathbf{y r} \mathbf{r}\right)\end{array}$ & $\begin{array}{c}\text { Total } \\
\left(\mathbf{k B t u} / \mathbf{f t}^{\mathbf{2}} \cdot \mathbf{y r} \mathbf{)}\right.\end{array}$ \\
\hline 1A & 30.6 & 16.7 & 29.1 & 76.4 \\
2A & 30.6 & 16.7 & 23.8 & 71.1 \\
2B & 30.9 & 16.7 & 24.9 & 72.5 \\
3A & 30.6 & 16.7 & 21.6 & 69.0 \\
3B & 30.6 & 16.7 & 20.5 & 67.8 \\
3C & 30.3 & 16.7 & 14.9 & 61.9 \\
4A & 30.6 & 16.8 & 20.2 & 67.6 \\
4B & 30.6 & 16.7 & 19.2 & 66.6 \\
4C & 30.6 & 16.8 & 16.9 & 64.2 \\
5A & 30.7 & 16.8 & 22.4 & 69.9 \\
5B & 30.7 & 16.8 & 19.3 & 66.7 \\
6A & 30.7 & 16.8 & 22.6 & 70.1 \\
6B & 30.8 & 16.8 & 19.4 & 66.9 \\
7 & 30.9 & 16.8 & 26.5 & 74.1 \\
8 & 31.1 & 16.8 & 34.6 & 82.5 \\
\hline
\end{tabular}

Table 26. Secondary School Source Energy Targets

\begin{tabular}{|c|c|c|c|c|}
\hline $\begin{array}{l}\text { Climate } \\
\text { Zone }\end{array}$ & $\begin{array}{l}\text { Plug/Process } \\
\text { (kBtu/ft' } \cdot \mathbf{y r})\end{array}$ & $\begin{array}{c}\text { Lighting } \\
\left(\mathrm{kBtu} / \mathrm{ft}^{2} \cdot \mathrm{yr}\right)\end{array}$ & $\begin{array}{c}\text { HVAC } \\
\left(k B t u / \mathrm{ft}^{2} \cdot \mathrm{yr}\right)\end{array}$ & $\begin{array}{c}\text { Total } \\
\left(\mathrm{kBtu} / \mathrm{ft}^{2} \cdot \mathrm{yr}\right)\end{array}$ \\
\hline $1 \mathrm{~A}$ & 22.2 & 19.5 & 26.8 & 68.5 \\
\hline $2 \mathrm{~A}$ & 22.4 & 19.6 & 21.6 & 63.5 \\
\hline $2 B$ & 22.4 & 19.5 & 22.5 & 64.3 \\
\hline $3 A$ & 22.5 & 19.6 & 19.5 & 61.6 \\
\hline $3 B$ & 22.4 & 19.5 & 18.2 & 60.2 \\
\hline $3 C$ & 22.5 & 19.6 & 12.3 & 54.3 \\
\hline $4 \mathrm{~A}$ & 22.6 & 19.6 & 17.9 & 60.1 \\
\hline $4 B$ & 22.6 & 19.5 & 16.6 & 58.8 \\
\hline $4 C$ & 22.6 & 19.6 & 14.1 & 56.4 \\
\hline $5 A$ & 22.8 & 19.6 & 19.8 & 62.2 \\
\hline $5 B$ & 22.7 & 19.6 & 16.2 & 58.4 \\
\hline $6 \mathrm{~A}$ & 22.8 & 19.6 & 19.4 & 61.9 \\
\hline $6 B$ & 22.9 & 19.6 & 16.0 & 58.4 \\
\hline 7 & 23.0 & 19.6 & 22.5 & 65.1 \\
\hline 8 & 23.2 & 19.7 & 28.5 & 71.5 \\
\hline
\end{tabular}

Whole-building absolute targets are supplemented with key end-use energy targets (plug and process loads, lighting systems, and HVAC systems). Although the end-use targets need not be met to achieve the whole-building target, these targets provide guidance about how energy use is likely to be distributed throughout a $\mathrm{K}-12$ school building, and they can also inform end-use energy budgets. Programmatic requirements are relatively constant for a given school type (primary or secondary). Accordingly, the whole-building and end-use energy targets in this feasibility study are likely to apply reasonably well to most $\mathrm{K}-12$ school building projects. The feasibility study energy targets do not take into account the energy use of specialty space types, such as indoor swimming pools, wet laboratories (e.g., chemistry), dirty dry laboratories (e.g., woodworking and auto shops), or other unique spaces that generate extraordinary heat or pollution. Such space types should be analyzed separately; their predicted energy use can be combined with the feasibility study targets included here to determine an area-weighted, wholebuilding energy use target that correctly reflects all energy uses. 


\section{Evaluation Results}

This section contains energy-efficiency measures that are recommended for developing zero energy K-12 schools. The energy savings that result from applying these approaches are presented as well. End-use comparison figures are provided, and the end-use data are also presented in tabular format.

The strategies in this feasibility study represent a way to achieve zero energy in a typical $\mathrm{K}-12$ school. It is recognized that there are other ways of achieving zero energy, especially on the energy consumption side of the building. When a strategy contains the designation "Comply with 90.1," this feasibility study used ASHRAE 90.1 (ASHRAE 2013b) for that component or system.

\subsection{A Pathway for Zero Energy}

This section provides the energy-efficiency measure values used to achieve a zero energy school for the purposes of showing that zero energy is achievable. It also demonstrates the types of efficiency levels needed to reach a target EUI. The opaque envelope values are presented for different climate zones by roof, wall, floor, slab, and door type. Values for the thermal characteristics of the vertical fenestration as well as the interior reflectance are provided. Interior lighting values - including LPD, lamp efficacy, controls, and daylighting system integration as well as exterior LPDs and controls - are presented. Plug and process load (including commercial kitchen equipment) strategies are provided. SWH efficiency values are provided for electric and gas water heaters as well as instantaneous or natural gas-fired water storage tank units. Many types of HVAC systems could be used in K-12 schools, but this feasibility study used a GSHP system with a DOAS for ventilation.

The model parameters to achieve the target EUIs are shown in Table 27 and Table 28. 
Table 27. Feasibility Study Values-Climate Zones 1-4

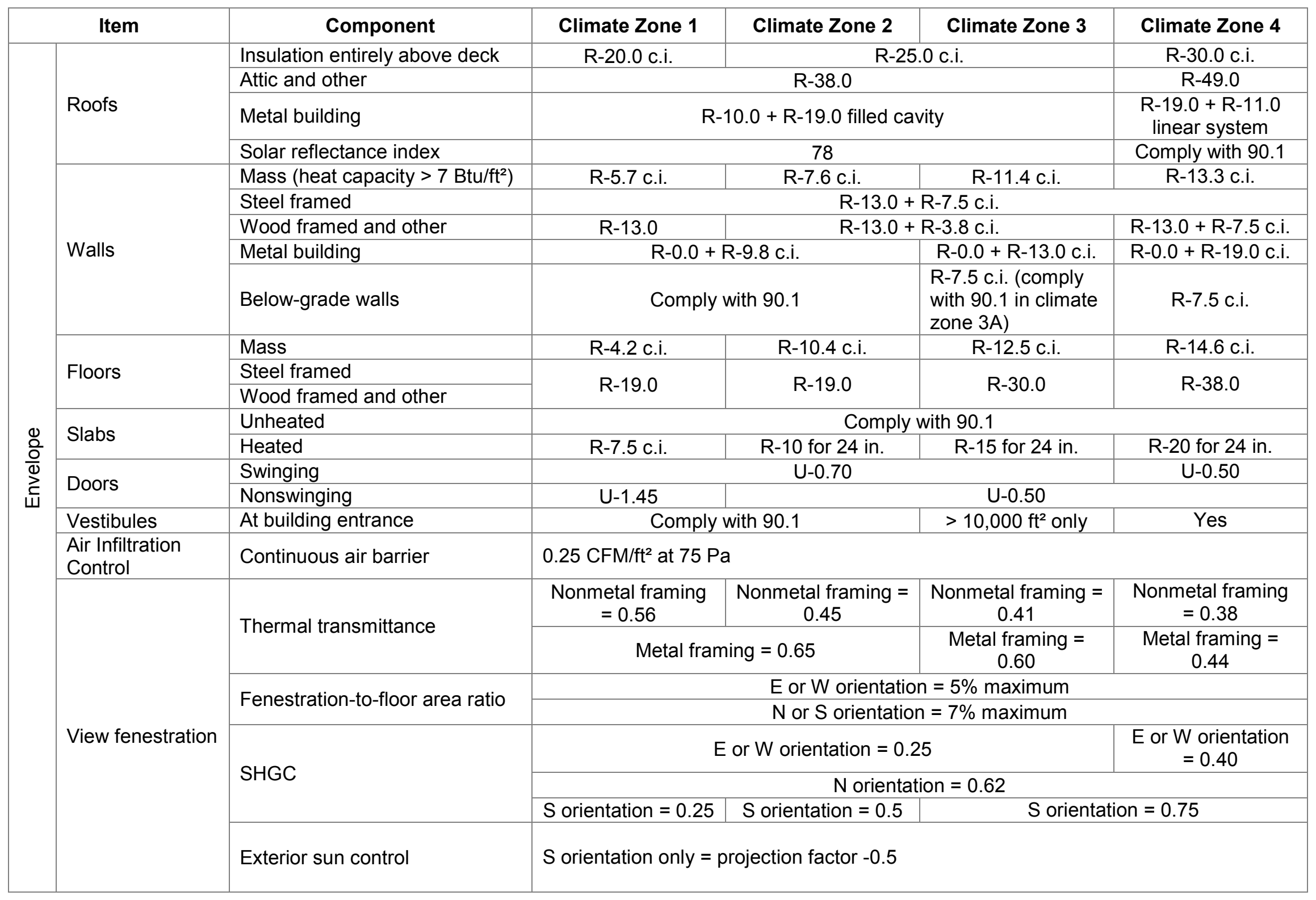




\begin{tabular}{|c|c|c|c|c|c|c|}
\hline & Item & Component & Climate Zone 1 & Climate Zone 2 & Climate Zone 3 & Climate Zone 4 \\
\hline & Daylighting & $\begin{array}{l}\text { Classrooms, resource rooms, } \\
\text { cafeteria, gym, and } \\
\text { multipurpose rooms }\end{array}$ & Daylight perimeter & r area (within $15 \mathrm{ft}$ ) & $2 / 3$ of school hours & \\
\hline & & Administrative areas & Daylight perimeter & $r$ area (within $15 \mathrm{ft}$ ) & $2 / 3$ of school hour & \\
\hline & Interior finishes & $\begin{array}{l}\text { Interior surface average } \\
\text { reflectance for daylighted rooms }\end{array}$ & Ceilings $=80 \%$; wa & urfaces $=70 \%$ & & \\
\hline & & & Whole building $=0$ & $\mathrm{~V} / \mathrm{ft}^{2}$ & & \\
\hline & & & Gyms, multipurpos & $\mathrm{oms}=0.75 \mathrm{~W} / \mathrm{ft}^{2}$ & & \\
\hline & & & Classrooms, art roc & , kitchens, libraries & edia centers $=0.45$ & \\
\hline & & LPD & Cafeterias, lobbies & $.5 \mathrm{~W} / \mathrm{ft}^{2}$ & & \\
\hline 吾 & & & Offices $=0.5 \mathrm{~W} / \mathrm{ft}^{2}$ & & & \\
\hline 光 & Interior lighting & & Auditoriums, restro & $\mathrm{s}=0.5 \mathrm{~W} / \mathrm{ft}^{2}$ & & \\
\hline$\frac{\pi}{0}$ & 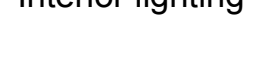 & & Corridors, mechani & rooms $=0.4 \mathrm{~W} / \mathrm{ft}^{2}$ & & \\
\hline 总 & & $\begin{array}{l}\text { Light source lamp efficacy } \\
\text { (mean lumens per Watt) }\end{array}$ & $100 \%$ LED & & & \\
\hline & & $\begin{array}{l}\text { Dimming controls daylight } \\
\text { harvesting }\end{array}$ & Dim all fixtures in $d$ & t zones & & \\
\hline & & Lighting controls & Manual ON, auto/ti & d OFF in all areas a & ossible & \\
\hline & & Façade and landscape lighting & $\begin{array}{l}\mathrm{LPD}=0.075 \mathrm{~W} / \mathrm{ft}^{2} \mathrm{i} \\
\text { Controls = auto OF }\end{array}$ & $\begin{array}{l}\text { Z3 and LZ4; LPD = } \\
\text { etween } 12 \text { a.m. anc }\end{array}$ & $\begin{array}{l}5 \mathrm{~W} / \mathrm{ft}^{2} \text { in LZ2; } \\
\text { a.m. }\end{array}$ & \\
\hline & Exterior lighting & Parking lots and drives & $\begin{array}{l}\mathrm{LPD}=0.1 \mathrm{~W} / \mathrm{ft}^{2} \text { in } \mathrm{L} \\
\text { Controls }=\text { auto red }\end{array}$ & $\begin{array}{l}\text { and LZ4; LPD }=0 \text {. } \\
\text { to } 25 \%(12 \text { a.m. tc }\end{array}$ & $\begin{array}{l}N / \mathrm{ft}^{2} \text { in LZ2; } \\
\text { a.m.) }\end{array}$ & \\
\hline & & $\begin{array}{l}\text { Walkways, plazas, and special } \\
\text { feature areas }\end{array}$ & $\begin{array}{l}\mathrm{LPD}=0.16 \mathrm{~W} / \mathrm{ft}^{2} \mathrm{~L} \\
\text { Controls = auto red }\end{array}$ & $\begin{array}{l}\text { and LZ4; LPD }=0.1 \\
\text { to } 25 \% \text { (12 a.m. tc }\end{array}$ & $\begin{array}{l}\text { //ft' in LZ2; } \\
\text { a.m.) }\end{array}$ & \\
\hline & & All other exterior lighting & LPD = follow $90.1-$ & 0 ; controls = auto $r$ & ce to $25 \%$ (12 a.m. & 6 a.m.) \\
\hline & & Laptop computers & Minimum $2 / 3$ of tot & omputers & & \\
\hline & $\begin{array}{l}\text { Equipment } \\
\text { choices }\end{array}$ & ENERGY STAR $^{\circledR}$ equipment & All computers, equi & ent, and appliances & & \\
\hline & & Vending machines & De-lamp and speci & est-in-class efficien & & \\
\hline & & Computer power control & Network control wit & ower saving modes & d control OFF durir & noccupied hours \\
\hline $\begin{array}{l}\frac{0}{0} \\
\frac{0}{2} \\
\frac{0}{\sigma} \\
\frac{0}{\sigma}\end{array}$ & & Power outlet control & $\begin{array}{l}\text { Controllable power } \\
\text { office, library/medic } \\
\text { to use controllable }\end{array}$ & $\begin{array}{l}\text { lets with auto OFF } \\
\text { aces. All plug-in eq } \\
\text { lets. }\end{array}$ & $\begin{array}{l}\text { ing unoccupied hol } \\
\text { ment not requiring }\end{array}$ & $\begin{array}{l}\text { for classrooms, } \\
\text { tinuous operation }\end{array}$ \\
\hline 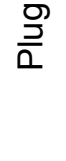 & controls & Policies & $\begin{array}{l}\text { Implement at least } \\
\text { - District/school po } \\
\text { - School energy te }\end{array}$ & on allowed equipm & & \\
\hline
\end{tabular}




\begin{tabular}{|c|c|c|c|c|c|c|}
\hline \multicolumn{2}{|r|}{ Item } & Component & Climate Zone 1 & Climate Zone 2 & Climate Zone 3 & Climate Zone 4 \\
\hline \multirow{3}{*}{ 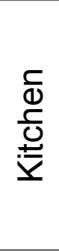 } & \multirow{3}{*}{$\begin{array}{l}\text { Kitchen } \\
\text { equipment }\end{array}$} & Cooking equipment & \multicolumn{4}{|c|}{ ENERGY STAR or California rebate-qualified equipment } \\
\hline & & Walk-in refrigeration equipment & \multicolumn{4}{|c|}{$\begin{array}{l}\text { 6-in. insulation on low-temp walk-in equipment, insulated floor, LED lighting, floating- } \\
\text { head pressure controls, liquid pressure amplifier, sub-cooled liquid refrigerant, } \\
\text { evaporative condenser }\end{array}$} \\
\hline & & Exhaust hoods & \multicolumn{4}{|c|}{$\begin{array}{l}\text { Side panels, larger overhangs, rear seal at appliances, proximity hoods, VAV demand- } \\
\text { based exhaust }\end{array}$} \\
\hline \multirow{6}{*}{$\sum_{\infty}^{T}$} & \multirow{6}{*}{ SWH } & Gas water heater (condensing) & \multicolumn{4}{|l|}{ 95\% efficiency } \\
\hline & & $\begin{array}{l}\text { Electric water heater } \\
(<12 \mathrm{~kW},>20 \mathrm{gal})\end{array}$ & \multicolumn{4}{|c|}{ Energy factor $(E F)>0.99-0.0012 \times$ volume } \\
\hline & & Point-of-use heater selection & \multicolumn{4}{|c|}{$0.81 \mathrm{EF}$ or $81 \%$ thermal efficiency } \\
\hline & & Electric heat pump water heater & \multicolumn{4}{|c|}{ COP 3.0 (interior heat source) } \\
\hline & & Solar water heating & \multicolumn{4}{|c|}{$30 \%$ solar hot water fraction when life cycle cost-effective } \\
\hline & & $\begin{array}{l}\text { Pipe insulation } \\
(\mathrm{d}<1.5 \text { in. } / \mathrm{d} \geq 1.5 \text { in. })\end{array}$ & \multicolumn{4}{|l|}{$1 \mathrm{in.} / 1.5 \mathrm{in}}$. \\
\hline \multirow{12}{*}{$\stackrel{\cup}{\gtrless}$} & \multirow{9}{*}{$\begin{array}{l}\text { GSHP system } \\
\text { with DOAS }\end{array}$} & GSHP cooling efficiency & \multicolumn{4}{|c|}{ 19.7 EER full load/49.1 EER part load } \\
\hline & & GSHP heating efficiency & \multicolumn{4}{|c|}{ 3.7 COP full load/4.4 COP part load } \\
\hline & & $\begin{array}{l}\text { GSHP compressor capacity } \\
\text { control }\end{array}$ & \multicolumn{4}{|c|}{ Two-stage or variable speed } \\
\hline & & Water circulation pumps & \multicolumn{4}{|c|}{$\begin{array}{l}\text { Variable-frequency drive (VFD) and National Electrical Manufacturers Association } \\
\text { premium efficiency }\end{array}$} \\
\hline & & Cooling tower/fluid cooler & \multicolumn{4}{|l|}{ VFD on fans } \\
\hline & & Boiler efficiency & \multicolumn{4}{|c|}{ 90\% combustion efficiency } \\
\hline & & Maximum fan power & \multicolumn{4}{|l|}{0.4 W/CFM } \\
\hline & & $\begin{array}{l}\text { Exhaust-air energy recovery in } \\
\text { DOAS }\end{array}$ & \multicolumn{2}{|c|}{$\begin{array}{l}\text { A (humid) zones: } 75 \% \text { enthalpy reduction } \\
\text { B (dry) zones: } 75 \% \text { dry-bulb temperature } \\
\text { reduction }\end{array}$} & \multicolumn{2}{|c|}{$\begin{array}{l}\text { A (humid) and C (marine) zones: } 75 \% \\
\text { enthalpy reduction } \\
B \text { (dry) zones: } 75 \% \text { dry-bulb temperature } \\
\text { reduction }\end{array}$} \\
\hline & & DOAS ventilation control & \multicolumn{4}{|l|}{ DCV with VFD } \\
\hline & \multirow{3}{*}{$\begin{array}{l}\text { Ducts and } \\
\text { dampers }\end{array}$} & Outdoor air damper & \multicolumn{4}{|l|}{ Motorized damper } \\
\hline & & Duct seal class & \multicolumn{4}{|l|}{ Seal Class A } \\
\hline & & Insulation level & \multicolumn{4}{|l|}{ R-6 } \\
\hline \multirow[t]{2}{*}{$\S$} & \multirow{2}{*}{$\begin{array}{l}\text { Measurement } \\
\text { and Verification } \\
\text { benchmarking }\end{array}$} & Electrical submetering & \multicolumn{4}{|c|}{$\begin{array}{l}\text { Separately meter lighting, HVAC, general } 120 \mathrm{~V} \text {, renewables, and whole building. } \\
\text { Begin submetering early to address issues during warranty period. }\end{array}$} \\
\hline & & Benchmarking & Benchmark monthl & nergy use and provic & training on benchm & king \\
\hline Rer & ewables & PV & $18 \%+$ efficiency roc & p/parking structure $\mathrm{F}$ & & \\
\hline
\end{tabular}


Table 28. Feasibility Study Values-Climate Zones 5-8

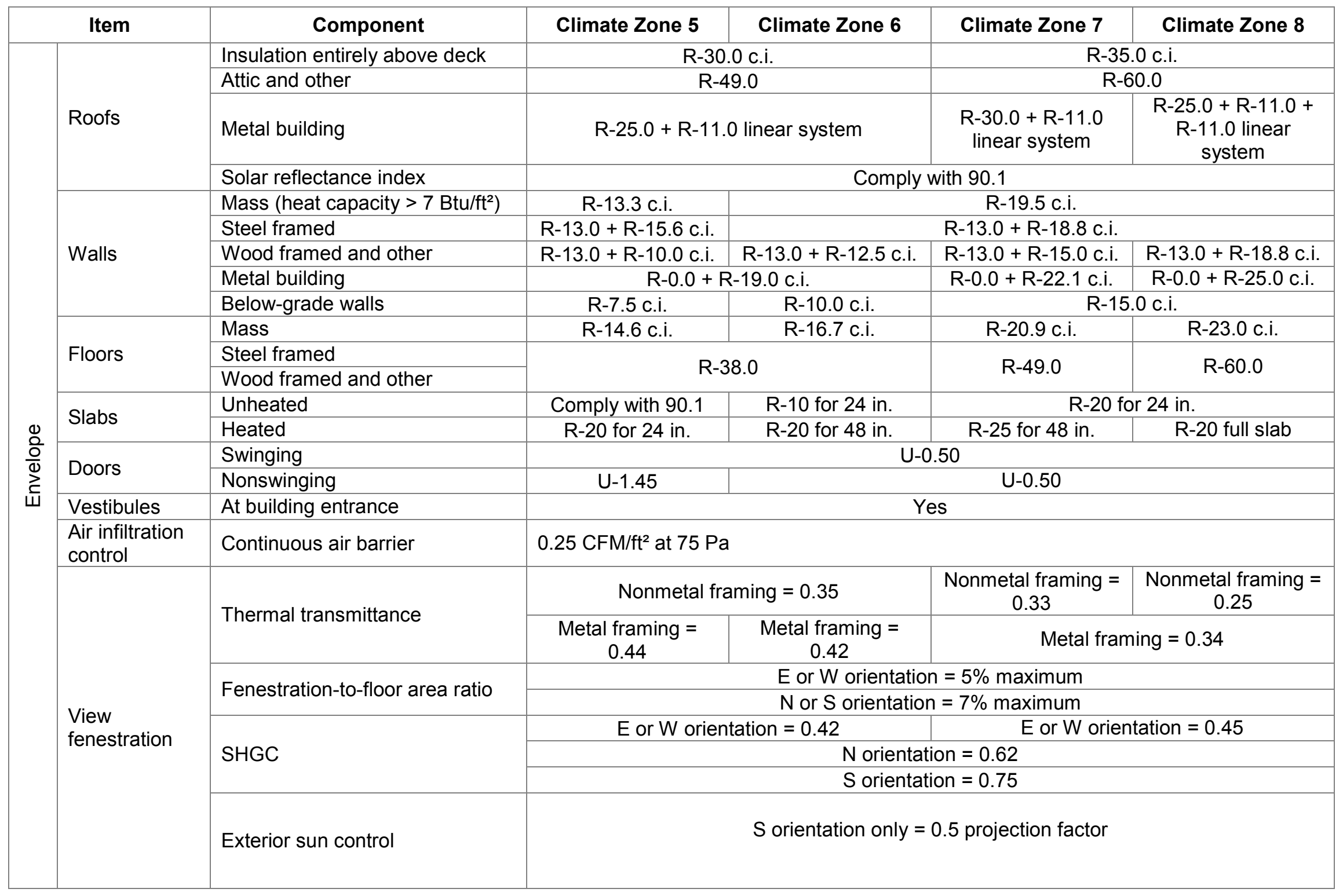




\begin{tabular}{|c|c|c|c|c|c|c|}
\hline \multicolumn{2}{|c|}{ Item } & Component & Climate Zone 5 & Climate Zone 6 & Climate Zone 7 & Climate Zone 8 \\
\hline \multirow{17}{*}{ 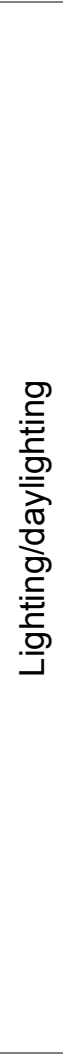 } & \multirow[t]{2}{*}{ Daylighting } & $\begin{array}{l}\text { Classrooms, resource rooms, } \\
\text { cafeteria, gym, and multipurpose } \\
\text { rooms }\end{array}$ & \multicolumn{4}{|c|}{ Daylight perimeter floor area (within $15 \mathrm{ft}$ ) for $2 / 3$ of school hours } \\
\hline & & Administrative areas & \multicolumn{4}{|c|}{ Daylight perimeter floor area (within $15 \mathrm{ft}$ ) for $2 / 3$ of school hours } \\
\hline & $\begin{array}{l}\text { Interior } \\
\text { finishes }\end{array}$ & $\begin{array}{l}\text { Interior surface average } \\
\text { reflectance for daylighted rooms }\end{array}$ & \multicolumn{4}{|c|}{ Ceilings $=80 \% ;$ wall surfaces $=70 \%$} \\
\hline & & & \multicolumn{4}{|c|}{ Whole building $=0.5 \mathrm{~W} / \mathrm{ft}^{2}$} \\
\hline & & & \multirow{2}{*}{\multicolumn{4}{|c|}{$\begin{array}{l}\text { Gyms, multipurpose rooms }=0.75 \mathrm{~W} / \mathrm{ft}^{2} \\
\text { Classrooms, art rooms, kitchens, libraries, media centers }=0.45 \mathrm{~W} / \mathrm{ft}^{2}\end{array}$}} \\
\hline & & & \multirow{2}{*}{\multicolumn{4}{|c|}{$\begin{array}{l}\text { Classrooms, art rooms, kitchens, libraries, media centers }=0.45 \mathrm{~W} / \mathrm{ft}^{2} \\
\text { Cafeterias, lobbies }=0.5 \mathrm{~W} / \mathrm{ft}^{2}\end{array}$}} \\
\hline & & LPD & & & & \\
\hline & & & \multicolumn{4}{|l|}{ Offices $=0.5 \mathrm{~W} / \mathrm{ft}^{2}$} \\
\hline & Interior & & \multicolumn{4}{|c|}{ Auditoriums, restrooms $=0.5 \mathrm{~W} / \mathrm{ft}^{2}$} \\
\hline & lighting & & \multicolumn{4}{|c|}{ Corridors, mechanical rooms $=0.4 \mathrm{~W} / \mathrm{ft}^{2}$} \\
\hline & & $\begin{array}{l}\text { Light source lamp efficacy } \\
\text { (mean lumens per Watt) }\end{array}$ & \multicolumn{4}{|l|}{$100 \%$ LED } \\
\hline & & $\begin{array}{l}\text { Dimming controls daylight } \\
\text { harvesting }\end{array}$ & \multicolumn{4}{|c|}{ Dim all fixtures in daylit zones } \\
\hline & & Lighting controls & \multicolumn{4}{|c|}{ Manual ON, auto/timed OFF in all areas as possible } \\
\hline & & Façade and landscape lighting & \multicolumn{4}{|c|}{$\begin{array}{l}\mathrm{LPD}=0.075 \mathrm{~W} / \mathrm{ft}^{2} \text { in LZ3 and LZ4; LPD }=0.05 \mathrm{~W} / \mathrm{ft}^{2} \text { in LZ2; } \\
\text { Controls = auto OFF between } 12 \text { a.m. and } 6 \text { a.m. }\end{array}$} \\
\hline & Exterior & Parking lots and drives & \multicolumn{4}{|c|}{$\begin{array}{l}\mathrm{LPD}=0.1 \mathrm{~W} / \mathrm{ft}^{2} \text { in } \mathrm{LZ3} \text { and LZ4; LPD }=0.06 \mathrm{~W} / \mathrm{ft}^{2} \text { in } \mathrm{LZ2} ; \\
\text { Controls }=\text { auto reduce to } 25 \%(12 \text { a.m. to } 6 \text { a.m.) }\end{array}$} \\
\hline & & $\begin{array}{l}\text { Walkways, plazas, and special } \\
\text { feature areas }\end{array}$ & \multicolumn{4}{|c|}{$\begin{array}{l}\mathrm{LPD}=0.16 \mathrm{~W} / \mathrm{ft}^{2} \mathrm{LZ3} \text { and LZ4; } \mathrm{LPD}=0.14 \mathrm{~W} / \mathrm{ft}^{2} \text { in } \mathrm{LZ2} ; \\
\text { Controls }=\text { auto reduce to } 25 \% \text { (12 a.m. to } 6 \text { a.m.) }\end{array}$} \\
\hline & & All other exterior lighting & \multicolumn{4}{|c|}{ LPD $=$ follow $90.1-2013 ;$ controls $=$ auto reduce to $25 \%$ (12 a.m. to 6 a.m.) } \\
\hline \multirow{6}{*}{ 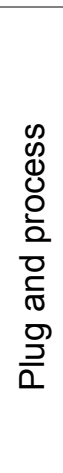 } & \multirow{3}{*}{$\begin{array}{l}\text { Equipment } \\
\text { choices }\end{array}$} & Laptop computers & \multicolumn{4}{|c|}{ Minimum $2 / 3$ of total computers } \\
\hline & & ENERGY STAR equipment & \multicolumn{4}{|c|}{ All computers, equipment, and appliances } \\
\hline & & Vending machines & \multicolumn{4}{|c|}{ De-lamp and specify best-in-class efficiency } \\
\hline & \multirow{3}{*}{ Controls } & Computer power control & \multicolumn{4}{|c|}{ Network control with power saving modes and control OFF during unoccupied hours } \\
\hline & & Power outlet control & \multicolumn{4}{|c|}{$\begin{array}{l}\text { Controllable power outlets with auto OFF during unoccupied hours for classrooms, } \\
\text { office, library/media spaces. All plug-in equipment not requiring continuous operation to } \\
\text { use controllable outlets. }\end{array}$} \\
\hline & & Policies & \multicolumn{4}{|c|}{$\begin{array}{l}\text { Implement at least one: } \\
\text { - District/school policy on allowed equipment } \\
\text { - School energy teams }\end{array}$} \\
\hline
\end{tabular}




\begin{tabular}{|c|c|c|c|c|c|c|}
\hline \multicolumn{2}{|r|}{ Item } & Component & Climate Zone 5 & Climate Zone 6 & Climate Zone 7 & Climate Zone 8 \\
\hline \multirow{3}{*}{ 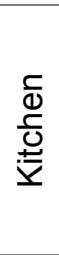 } & \multirow{3}{*}{$\begin{array}{l}\text { Kitchen } \\
\text { equipment }\end{array}$} & Cooking equipment & \multicolumn{4}{|c|}{ ENERGY STAR or California rebate-qualified equipment } \\
\hline & & Walk-in refrigeration equipment & \multicolumn{4}{|c|}{$\begin{array}{l}\text { 6-in. insulation on low-temp walk-in equipment, insulated floor, LED lighting, floating- } \\
\text { head pressure controls, liquid pressure amplifier, sub-cooled liquid refrigerant, } \\
\text { evaporative condenser }\end{array}$} \\
\hline & & Exhaust hoods & \multicolumn{4}{|c|}{$\begin{array}{l}\text { Side panels, larger overhangs, rear seal at appliances, proximity hoods, VAV demand- } \\
\text { based exhaust }\end{array}$} \\
\hline \multirow{6}{*}{$\sum_{\omega}^{T}$} & \multirow{6}{*}{$\mathrm{SWH}$} & Gas water heater (condensing) & \multicolumn{4}{|l|}{ 95\% efficiency } \\
\hline & & $\begin{array}{l}\text { Electric water heater } \\
(<12 \mathrm{~kW},>20 \text { gal })\end{array}$ & \multicolumn{4}{|c|}{ Energy factor $(E F)>0.99-0.0012 \times$ volume } \\
\hline & & Point-of-use heater selection & \multicolumn{4}{|c|}{$0.81 \mathrm{EF}$ or $81 \%$ thermal efficiency } \\
\hline & & Electric heat pump water heater & \multicolumn{4}{|c|}{ COP 3.0 (interior heat source) } \\
\hline & & Solar water heating & \multicolumn{4}{|c|}{$30 \%$ solar hot water fraction when life cycle cost-effective } \\
\hline & & $\begin{array}{l}\text { Pipe insulation } \\
(d<1.5 \text { in. } / d \geq 1.5 \text { in. })\end{array}$ & \multicolumn{4}{|c|}{$1 \mathrm{in.} / 1.5 \mathrm{in.}$} \\
\hline \multirow{12}{*}{$\stackrel{\cup}{\gtrless}$} & \multirow{9}{*}{$\begin{array}{l}\text { GSHP system } \\
\text { with DOAS }\end{array}$} & GSHP cooling efficiency & \multicolumn{4}{|c|}{ 19.7 EER full load/49.1 EER part load } \\
\hline & & GSHP heating efficiency & \multicolumn{4}{|c|}{ 3.7 COP full load/4.4 COP part load } \\
\hline & & $\begin{array}{l}\text { GSHP compressor capacity } \\
\text { control }\end{array}$ & \multicolumn{4}{|c|}{ Two-stage or variable speed } \\
\hline & & Water circulation pumps & \multicolumn{4}{|c|}{ VFD and National Electrical Manufacturers Association premium efficiency } \\
\hline & & Cooling tower/fluid cooler & \multicolumn{4}{|l|}{ VFD on fans } \\
\hline & & Boiler efficiency & \multicolumn{4}{|c|}{$90 \%$ combustion efficiency } \\
\hline & & Maximum fan power & \multicolumn{4}{|c|}{0.4 W/CFM } \\
\hline & & $\begin{array}{l}\text { Exhaust-air energy recovery in } \\
\text { DOAS }\end{array}$ & $\begin{array}{l}\text { A (humid) zones: } \\
75 \% \text { enthalpy } \\
\text { reduction } \\
\text { B (dry) zones: } 75 \% \\
\text { dry-bulb } \\
\text { temperature } \\
\text { reduction }\end{array}$ & $\begin{array}{l}\text { A (humid) zones: } 7 \\
\text { B (dry) zones: } 75 \% \\
\text { reduction }\end{array}$ & $\begin{array}{l}\text { nthalpy reduction } \\
\text { bulb temperature }\end{array}$ & $\begin{array}{l}75 \% \text { dry-bulb } \\
\text { temperature } \\
\text { reduction }\end{array}$ \\
\hline & & DOAS ventilation control & \multicolumn{4}{|l|}{ DCV with VFD } \\
\hline & \multirow{3}{*}{$\begin{array}{l}\text { Ducts and } \\
\text { dampers }\end{array}$} & Outdoor air damper & \multicolumn{4}{|l|}{ Motorized damper } \\
\hline & & Duct seal class & \multicolumn{4}{|l|}{ Seal Class A } \\
\hline & & Insulation level & \multicolumn{4}{|l|}{$\mathrm{R}-6$} \\
\hline \multirow{2}{*}{$\varangle$} & \multirow{2}{*}{$\begin{array}{l}\text { Measurement } \\
\text { and } \\
\text { Verification } \\
\text { benchmarking }\end{array}$} & Electrical submetering & \multicolumn{4}{|c|}{$\begin{array}{l}\text { Separately meter lighting, HVAC, general } 120 \mathrm{~V} \text {, renewables, and whole building. Begin } \\
\text { submetering early to address issues during warranty period. }\end{array}$} \\
\hline & & Benchmarking & \multicolumn{4}{|c|}{ Benchmark monthly energy use and provide training on benchmarking } \\
\hline
\end{tabular}




\begin{tabular}{|c|c|c|c|c|c|}
\hline Item & \multicolumn{1}{|c|}{ Component } & Climate Zone 5 & Climate Zone 6 & Climate Zone 7 & Climate Zone 8 \\
\hline Renewables & PV & $18 \%+$ efficiency rooftop/parking structure PV & & \\
\hline
\end{tabular}




\subsection{Energy Simulation Results}

When the feasibility study findings were compiled and the final zero energy models were simulated, the goal of zero energy was met or exceeded in all continental U.S. climate zones. Energy consumption values included plug loads and exterior lighting. Energy consumption by school type did not vary significantly from one climate zone to another.

Table 29 and Figure 45-Figure 50 illustrate the results.

Table 29. Energy Intensity Values for Zero Energy Schools

\begin{tabular}{|c|c|c|c|c|c|}
\hline \multirow[b]{2}{*}{$\begin{array}{l}\text { Climate } \\
\text { Zone }\end{array}$} & \multirow[b]{2}{*}{$\begin{array}{c}\text { Representative } \\
\text { City }\end{array}$} & \multicolumn{2}{|c|}{ Primary School } & \multicolumn{2}{|c|}{ Secondary School } \\
\hline & & $\begin{array}{l}\text { Site Energy } \\
\left(\mathbf{k B t u} / \mathrm{ft}^{2} \cdot \mathbf{y r}\right)\end{array}$ & $\begin{array}{c}\text { Source } \\
\text { Energy } \\
\left.\text { (kBtu/ft' }{ }^{2} \cdot \mathrm{yr}\right)\end{array}$ & $\begin{array}{l}\text { Site Energy } \\
\left(\mathbf{k B t u} / \mathrm{ft}^{2} \cdot \mathrm{yr}\right)\end{array}$ & 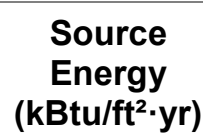 \\
\hline $1 \mathrm{~A}$ & Miami, FL & 25.9 & 76.4 & 23.1 & 68.5 \\
\hline $2 \mathrm{~A}$ & Houston, TX & 24.3 & 71.1 & 21.7 & 63.5 \\
\hline $2 B$ & Phoenix, AZ & 24.7 & 72.5 & 21.9 & 64.3 \\
\hline $3 \mathrm{~A}$ & Memphis, TN & 23.8 & 69.0 & 21.2 & 61.6 \\
\hline 3B & El Paso, TX & 23.4 & 67.8 & 20.7 & 60.2 \\
\hline $3 C$ & San Francisco, CA & 21.6 & 61.9 & 19.0 & 54.3 \\
\hline $4 \mathrm{~A}$ & Baltimore, MD & 23.5 & 67.6 & 20.9 & 60.1 \\
\hline $4 B$ & Albuquerque, NM & 23.1 & 66.6 & 20.4 & 58.8 \\
\hline $4 C$ & Salem, OR & 22.4 & 64.2 & 19.7 & 56.4 \\
\hline $5 \mathrm{~A}$ & Chicago, IL & 24.3 & 69.9 & 21.6 & 62.2 \\
\hline $5 B$ & Boise, ID & 23.2 & 66.7 & 20.4 & 58.4 \\
\hline $6 \mathrm{~A}$ & Burlington, VT & 24.5 & 70.1 & 21.6 & 61.9 \\
\hline $6 B$ & Helena, MT & 23.5 & 66.9 & 20.5 & 58.4 \\
\hline 7 & Duluth, MN & 25.9 & 74.1 & 22.8 & 65.1 \\
\hline 8 & Fairbanks, AL & 28.7 & 82.5 & 25.0 & 71.5 \\
\hline
\end{tabular}




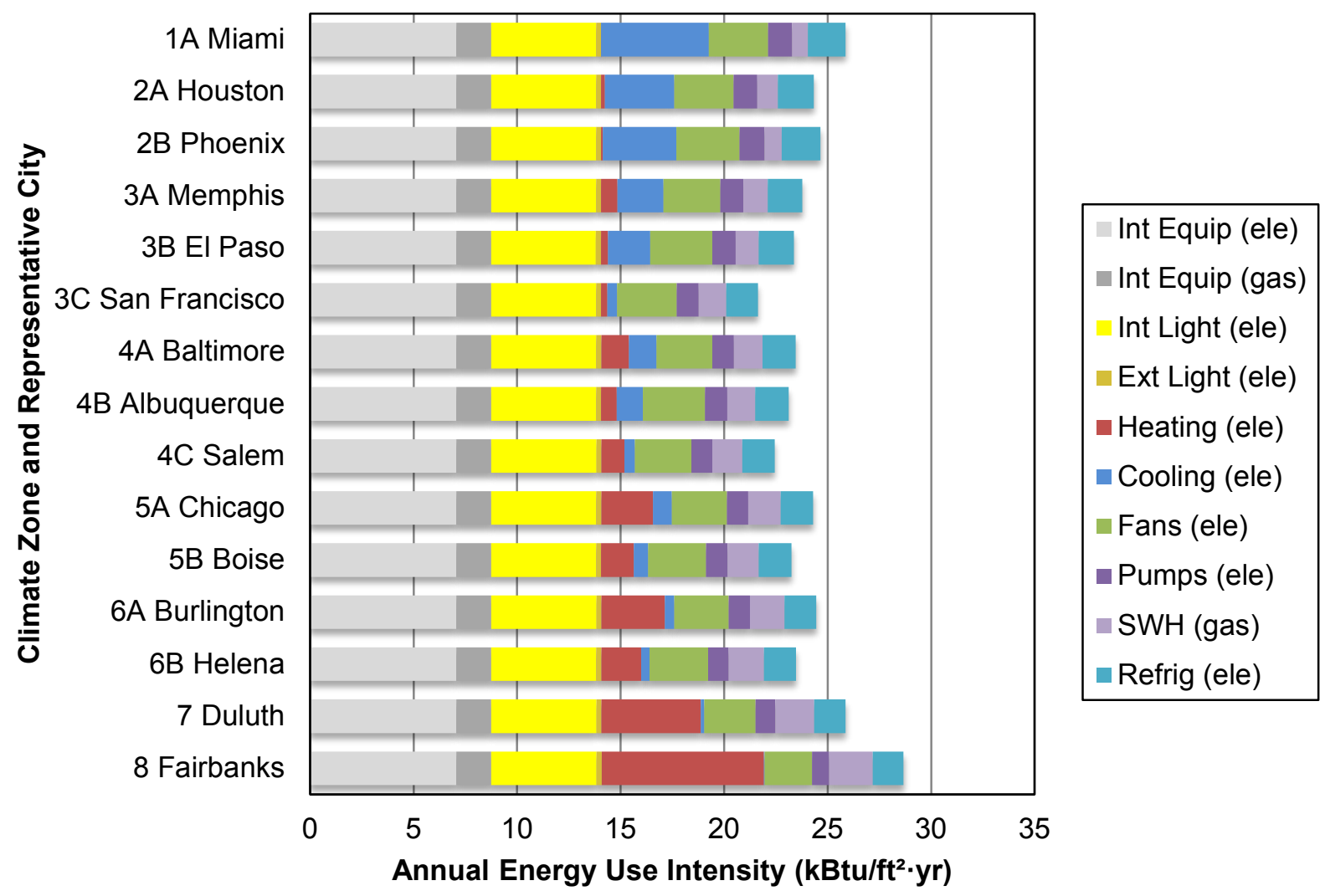

Figure 45. Site energy intensity values for zero energy-primary school. 


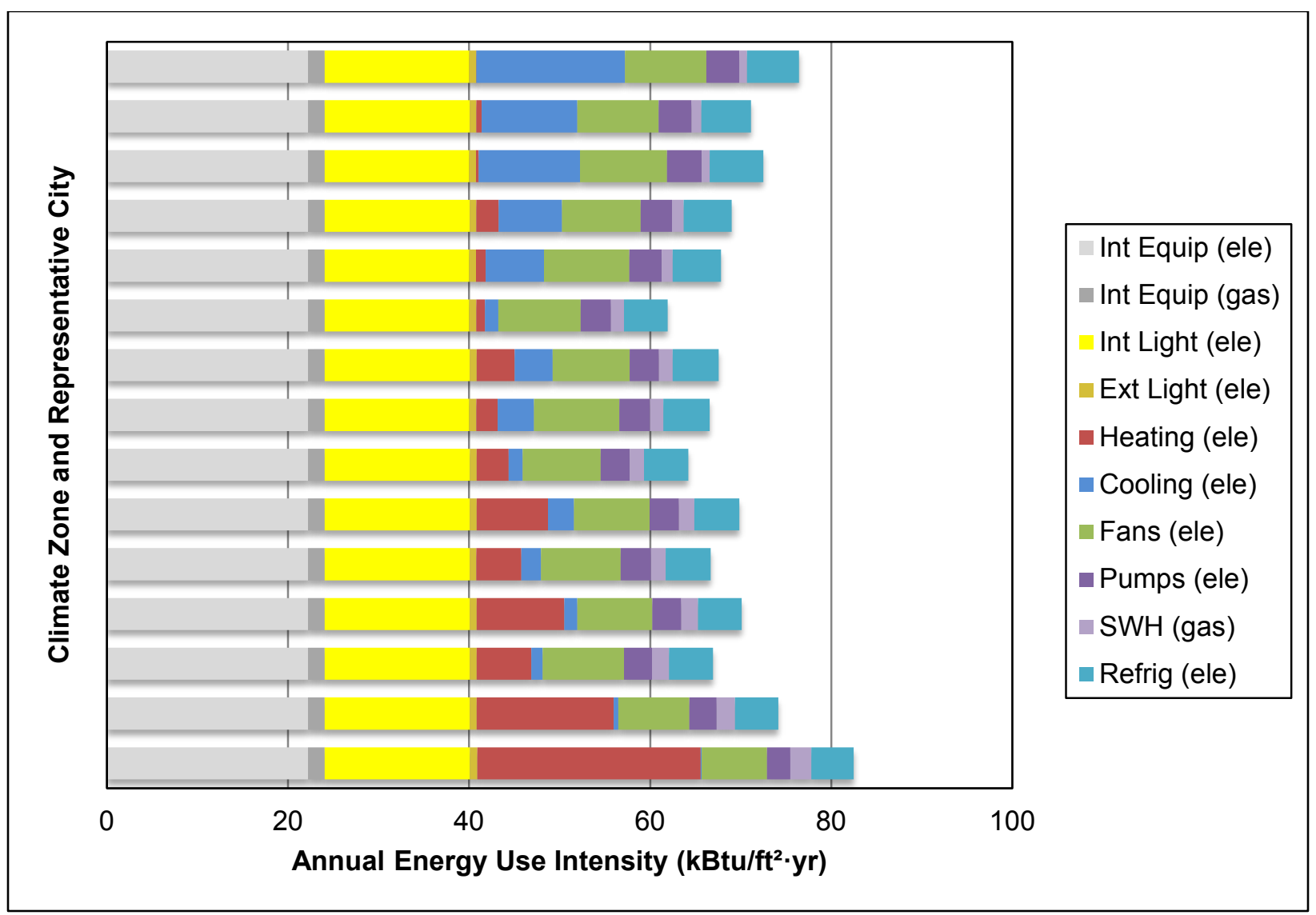

Figure 46. Source energy intensity values for zero energy_primary school. 


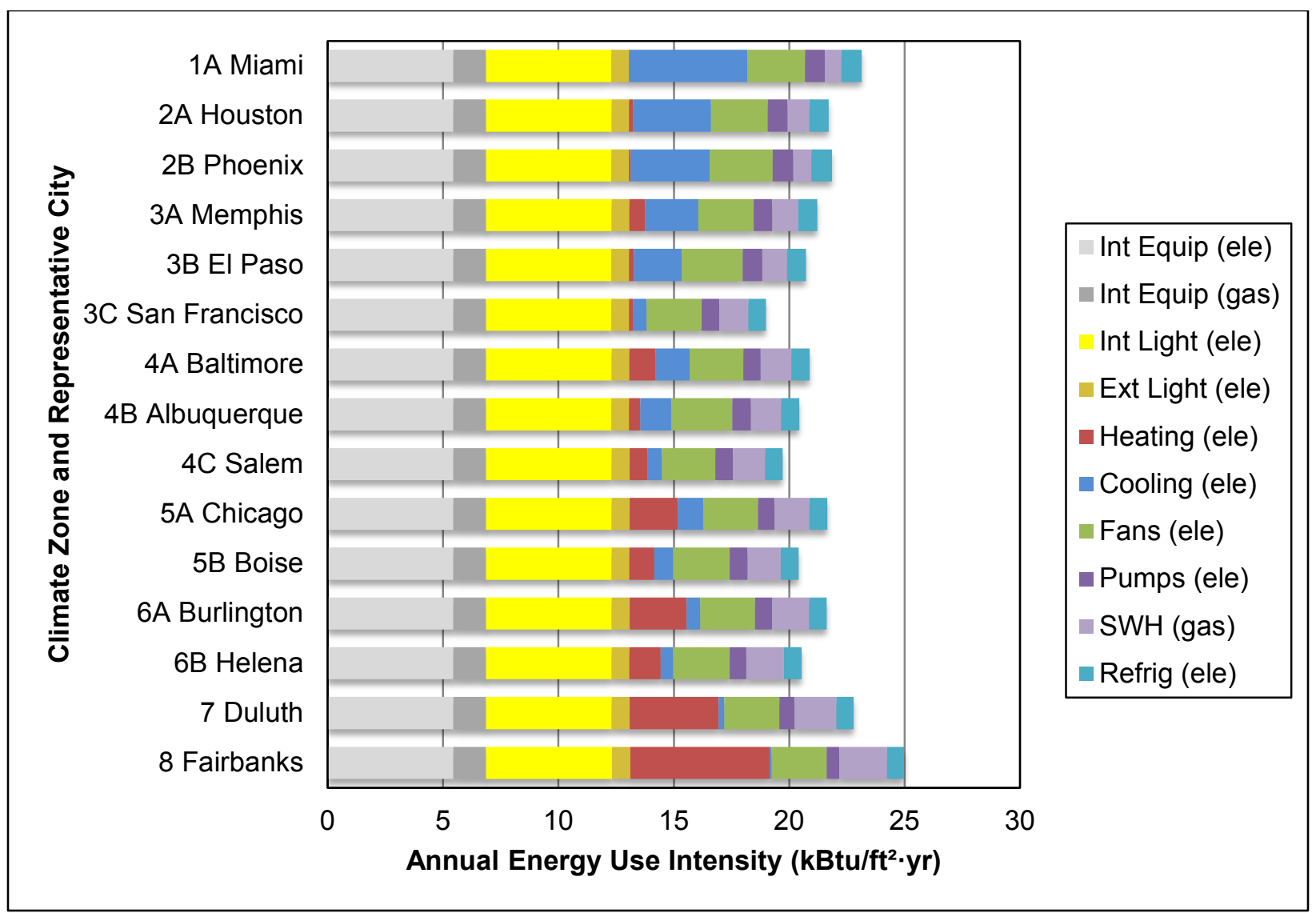

Figure 47. Site energy intensity values for zero energy-secondary school. 


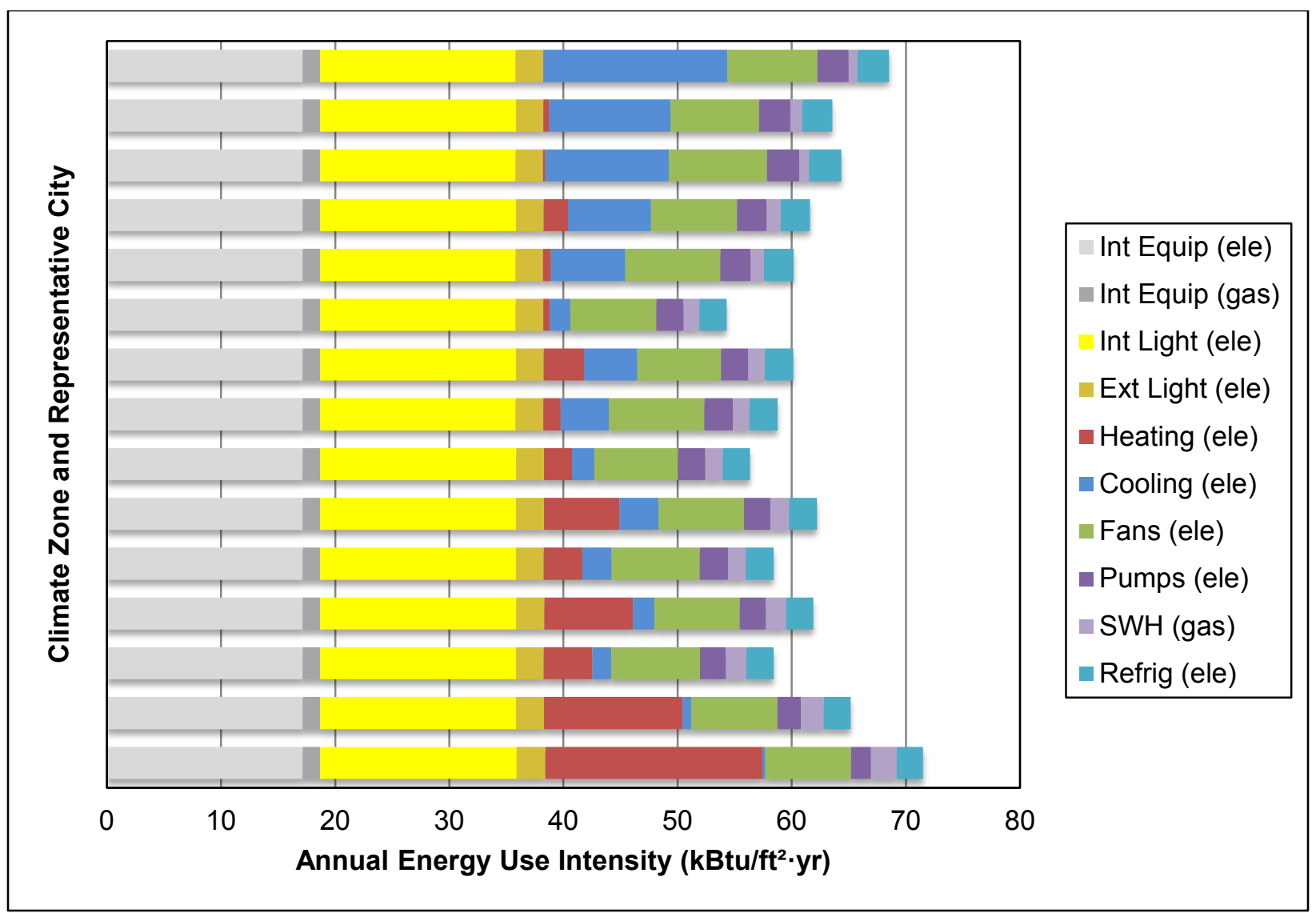

Figure 48. Source energy intensity values for zero energy-secondary school. 


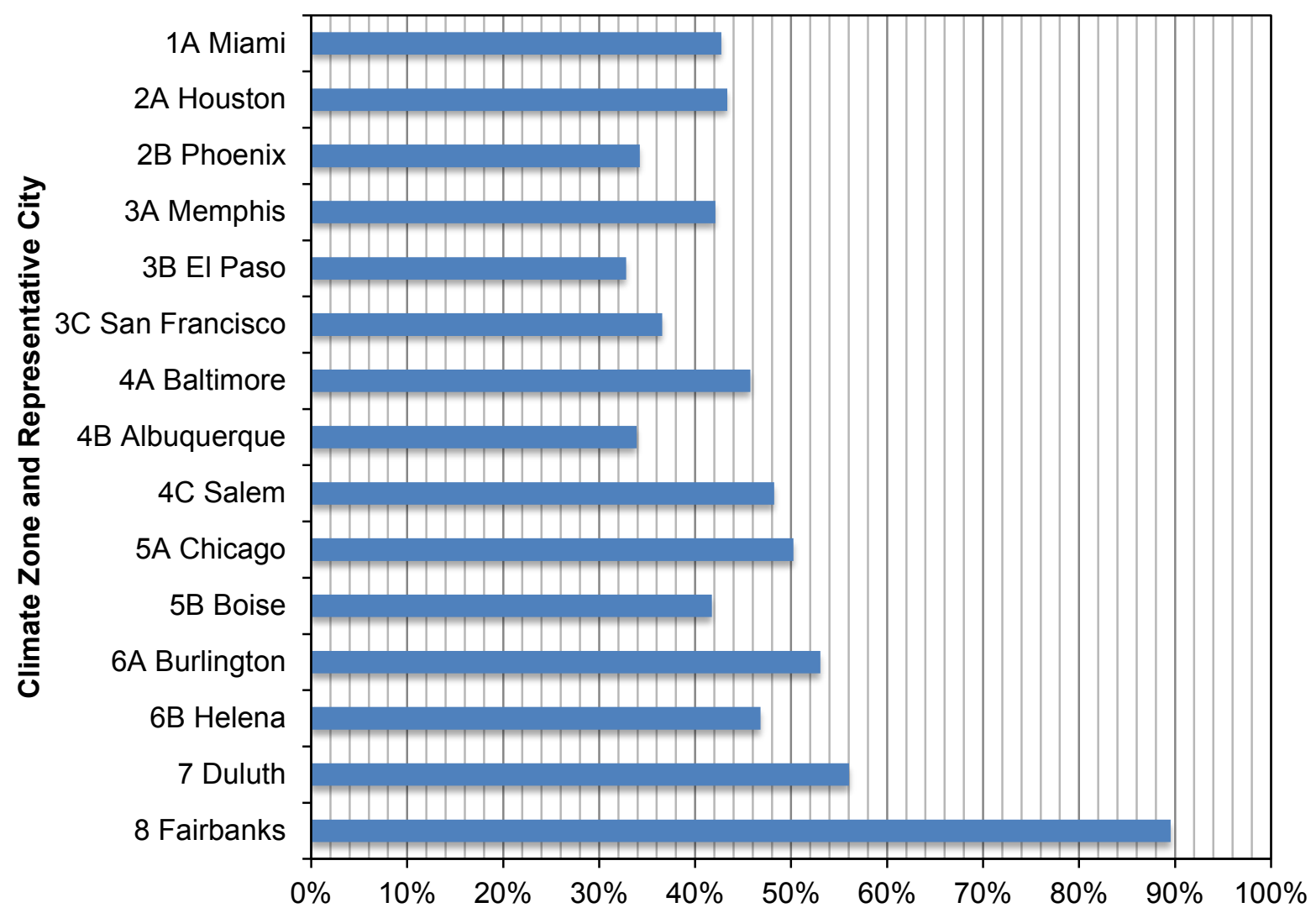

Figure 49. Rooftop PV coverage percentage to achieve zero energy_primary school. 


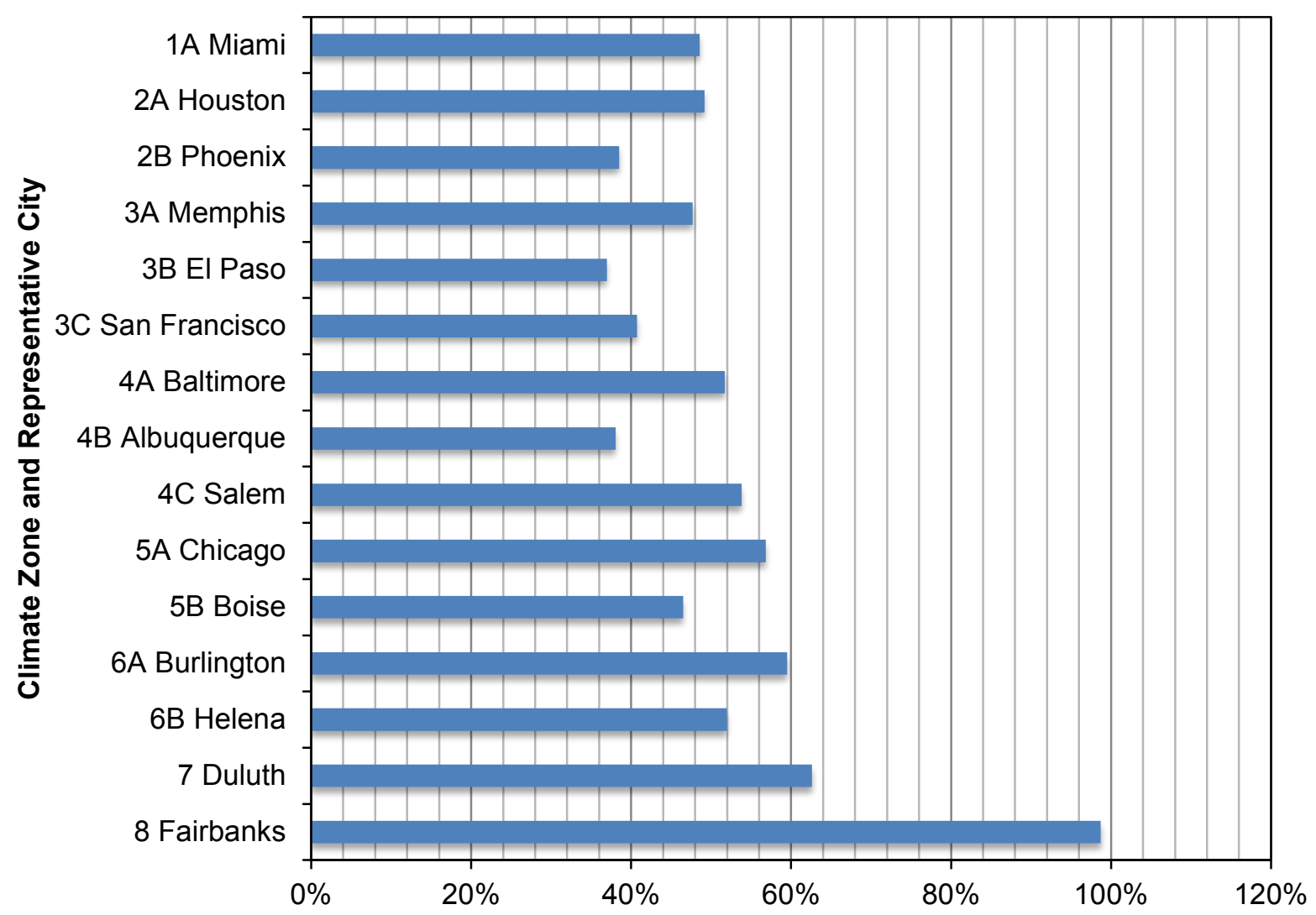

Figure 50. Rooftop PV coverage percentage to achieve zero energy-secondary school. 


\section{Case Studies}

Case studies provide evidence that the solutions suggested in this study are technically viable and can be employed today at a reasonable cost. Case studies of actual $\mathrm{K}-12$ school applications also strengthen the business case for taking advantage of these energy-efficiency opportunities.

ZEBs are a relatively new concept, limited design guidance is available. In addition, existing case studies are often highly customized for a particular school application. Table 30 shows case studies that have been identified as targeting zero energy or schools that have reported having exceptional energy performance. These schools were then evaluated based on actual data (some are too new to have data), with renewable energy installed, or having retained the renewable energy credits. At present, based on preliminary data, only two of the schools have been shown to meet the DOE definition of a ZEB. 


\begin{tabular}{|c|c|c|c|c|c|c|c|c|c|}
\hline Name & Location & $\begin{array}{l}\text { Grade } \\
\text { Levels }\end{array}$ & $\begin{array}{l}\text { Project } \\
\text { Size }\left(\mathrm{ft}^{2}\right)\end{array}$ & $\begin{array}{l}\text { IECC } \\
\text { Climate } \\
\text { Zone }\end{array}$ & $\begin{array}{l}\text { Date } \\
\text { Opened }\end{array}$ & $\begin{array}{l}\text { EUI wl } \\
\text { Renewables } \\
\left(\text { kBtu/ft' } \text { ftyr) }^{2}\right.\end{array}$ & $\begin{array}{l}\text { Site EUI } \\
\left(\mathrm{kBtu} / \mathrm{ft}^{2} \cdot \mathrm{yr}\right)\end{array}$ & $\begin{array}{l}\text { Entire } \\
\text { School? }\end{array}$ & $\begin{array}{l}\text { Retain } \\
\text { Renew- } \\
\text { able } \\
\text { Energy } \\
\text { Certifi- } \\
\text { cates } \\
\text { (RECs) }\end{array}$ \\
\hline Sandy Grove Middle School & $\begin{array}{l}\text { Lumber Ridge, } \\
\text { NC }\end{array}$ & $6-8$ & 75,930 & $4 \mathrm{~A}$ & Sept. 2013 & -10.16 & 24.38 & Yes & Yes \\
\hline $\begin{array}{l}\text { Locust Trace AgriScience } \\
\text { Campus }\end{array}$ & Lexington, KY & $9-12$ & 44,248 & $4 \mathrm{~A}$ & Aug. 2011 & -0.68 & 9.4 & Yes & Unknown \\
\hline $\begin{array}{l}\text { Lady Bird Johnson Middle } \\
\text { School }\end{array}$ & Irving, TX & $6-8$ & 152,250 & 3B & Aug. 2011 & -0.04 & 17 & Yes & Yes \\
\hline Richardsville Elementary & $\begin{array}{l}\text { Bowling Green, } \\
\text { KY }\end{array}$ & PK-6 & 72,285 & $4 \mathrm{~A}$ & Sept. 2010 & 1.3 & 20.47 & Yes & No, sells \\
\hline Lee Elementary School & Coppell, TX & $\mathrm{PK}-5$ & 150,000 & $3 \mathrm{~B}$ & Sept. 2014 & Unknown & 18.3 & Yes & Unknown \\
\hline Kiowa County K-12 School & Greensburg, KS & $\mathrm{K}-12$ & 123,000 & $4 \mathrm{~A}$ & July 2011 & 24.7 & 30.1 & Yes & Unknown \\
\hline Friends School in Maine & $\begin{array}{l}\text { Cumberland, } \\
\text { ME }\end{array}$ & PK-8 & 15,000 & $6 \mathrm{~A}$ & Sept. 2015 & Unknown & Unknown & Yes & Unknown \\
\hline $\begin{array}{l}\text { P.S. } 62 \text { The Kathleen Grimm } \\
\text { School }\end{array}$ & New York, NY & PK-5 & 68,000 & $4 \mathrm{~A}$ & Sept. 2015 & Unknown & 29 & Yes & Unknown \\
\hline Discovery Elementary School & Arlington, VA & $\mathrm{PK}-5$ & 98,000 & $4 \mathrm{~A}$ & Sept. 2015 & 0 & 22 & Yes & Unknown \\
\hline MLK School & Boston, MA & PK-8 & 169,000 & $5 \mathrm{~A}$ & Ongoing & Unknown & 35 & Yes & Unknown \\
\hline Meadowbrook Elementary & Gainesville, FL & $\mathrm{PK}-12$ & 95,620 & $2 \mathrm{~A}$ & July 2012 & Unknown & 27.7 & Yes & Unknown \\
\hline Sacred Heart, Stevens Library & Atherton, CA & $\mathrm{PK}-12$ & 6,800 & $3 \mathrm{~B}$ & Oct. 2011 & -12.2 & 16.9 & No & Unknown \\
\hline $\begin{array}{l}\text { Hood River Middle School Music } \\
\text { and Science Building }\end{array}$ & Hood River, OR & $6-8$ & 7,000 & 4B & May 2011 & 0.33 & 20.3 & No & Unknown \\
\hline
\end{tabular}




\begin{tabular}{|c|c|c|c|c|c|c|c|c|c|}
\hline Name & Location & $\begin{array}{l}\text { Grade } \\
\text { Levels }\end{array}$ & $\begin{array}{l}\text { Project } \\
\text { Size }\left(\mathrm{ft}^{2}\right)\end{array}$ & $\begin{array}{l}\text { IECC } \\
\text { Climate } \\
\text { Zone }\end{array}$ & $\begin{array}{l}\text { Date } \\
\text { Opened }\end{array}$ & $\begin{array}{l}\text { EUI wl } \\
\text { Renewables } \\
\left(\text { kBtu/ft' } \text { fryr }^{2}\right.\end{array}$ & $\begin{array}{l}\text { Site EUI } \\
\left(\mathrm{kBtu} / \mathrm{ft}^{2} \cdot \mathrm{yr}\right)\end{array}$ & $\begin{array}{l}\text { Entire } \\
\text { School? }\end{array}$ & $\begin{array}{l}\text { Retain } \\
\text { Renew- } \\
\text { able } \\
\text { Energy } \\
\text { Certifi- } \\
\text { cates } \\
\text { (RECs) }\end{array}$ \\
\hline $\begin{array}{l}\text { Hawaii Preparatory Academy } \\
\text { Energy Lab }\end{array}$ & Waimea, $\mathrm{HI}$ & $\mathrm{K}-12$ & 6,100 & 1 & Jan. 2010 & -16.98 & 11 & No & Unknown \\
\hline $\begin{array}{l}\text { Bertschi School Living Science } \\
\text { Wing }\end{array}$ & Seattle, WA & $\mathrm{PK}-5$ & 1,425 & $4 \mathrm{C}$ & Feb. 2011 & -0.01 & 48 & No & Unknown \\
\hline The Putney School Field House & Putney, VT & $9-12$ & 16,000 & $6 \mathrm{~A}$ & Oct. 2009 & -0.78 & 9.65 & No & Unknown \\
\hline Marin Country Day School & $\begin{array}{l}\text { Corte Madera, } \\
\text { CA }\end{array}$ & PK-8 & 13,600 & 3B & Aug. 2011 & Unknown & 5.7 & No & Unknown \\
\hline $\begin{array}{l}\text { George V. Leyva Middle School } \\
\text { Administrative Building }\end{array}$ & San Jose, CA & $\mathrm{K}-6$ & 9,212 & 3B & June 2012 & Unknown & Unknown & No & Unknown \\
\hline da Vinci Arts Middle School & Portland, OR & $6-8$ & 1500 & $4 \mathrm{C}$ & Sept. 2009 & 2.3 & 27.1 & No & Unknown \\
\hline Evie Garrett Dennis Campus & Denver, CO & PK-12 & 186,468 & $5 \mathrm{~B}$ & Aug. 2010 & 28.2 & Unknown & No & Unknown \\
\hline Prairie Hill Learning Center & Roca, NE & PK-8 & 3,700 & $5 \mathrm{~B}$ & 2007 & Unknown & Unknown & No & Unknown \\
\hline
\end{tabular}

Legend:

Based on actual data (measured or from utility bills)

Based on predicted data 
Even with these limitations, however, case studies demonstrate that the strategies suggested in this feasibility study have merit and can be applied to a range of buildings. Case studies are also indications that zero energy schools are achievable among the many climate zones in the United States and provide a valid starting point for launching a concerted effort to increase the number of ZEBs in the United States. The following four case studies offer a variety of ZEB strategies and solutions in several climate zones.

\subsection{Richardsville Elementary}

Early in the design process, the Richardsville Elementary School team committed to delivering a 15-year simple return on any PV installed on the building. To achieve that goal, the team determined that the building could not exceed a site EUI target of $17 \mathrm{kBtu} / \mathrm{ft}^{2}$. $\mathrm{yr}$ so that the PV would match their energy loads. Table 31 and Table 32 summarize information about the school.

Although the latest data show that the school fell just short of its zero energy goals in 2015, the building has achieved impressive energy efficiency and did operate at zero energy for several years. (It did not, however, meet the DOE definition for zero energy because it sells the renewable energy certificates for its renewable energy production.)

Table 31. Richardsville Elementary School at a Glance

\begin{tabular}{ll}
\hline Characteristic & Value \\
\hline Location & Richardsville, KY \\
Climate zone & Zone 4, Mixed Humid \\
Owner & Warren County Public Schools \\
Building type & Elementary school \\
Number of occupants & 495 \\
Gross floor area & $72,285 \mathrm{ft}^{2}$ \\
New or renovation & New \\
Date of completion & September 2010 \\
Annual source energy with renewables & $93,038 \mathrm{kWh}^{\mathrm{a}}$ \\
Annual delivered energy & $433,809 \mathrm{kWh}$ \\
Renewable energy generated annually on-site & $404,273 \mathrm{kWh}$ \\
Site EUI & $20.47 \mathrm{kBtu} / \mathrm{ft}^{2} \cdot \mathrm{yr}$ \\
PV size & $348 \mathrm{~kW}$ \\
ailowatt-hours &
\end{tabular}

Table 32. Richardsville Elementary School Ratings and Awards

\begin{tabular}{cl}
\hline \multicolumn{1}{c}{ Program } & \multicolumn{1}{c}{ Year } \\
\hline Andromeda Award, Alliance to Save Energy & 2009 \\
American School \& University Magazine, Special Citation & 2008,2011 \\
\hline
\end{tabular}

\section{Design Process}

According to Kenny Stanfield of Sherman Carter Bernhart Architects, the stars aligned to allow Richardsville Elementary to be built as a ZEB, and the school board has not been able to do the same thing on another school since. Although the price of solar PV has steeply declined since Richardsville was built, new regulations in the district currently limit solar arrays to $30 \mathrm{~kW}$. Other schools in the area are PV ready, but Richardsville continues to be the only school in the district capable of operating at zero energy in a given year, and its energy systems have generated a positive cash flow for the school every year it has been in operation. 


\section{Energy Strategies}

Heating, Ventilating, and Air Conditioning

After choosing a water source heat pump for heating and cooling, the design team needed to improve efficiency of the DOAS if the project was to meet its energy goals. The school district had recently learned from the first few years of operating another low-energy school, Plano Elementary, that $40 \%$ of HVAC energy can be consumed by the outdoor air system; therefore, a variable-flow, dynamic reset system was selected for Richardsville. A pneumatic air system, combined with occupancy and carbon dioxide sensors, helps determine when to increase and decrease airflow. The system was predicted to consume $7.8 \mathrm{kBtu} / \mathrm{ft}^{2} \cdot \mathrm{yr}$ (site energy), and the water source heat pumps provide up to 120 tons of cooling.

\section{Envelope}

Insulated concrete form walls and metal roofing with 6 in. of polyisocyanurate insulation were used to create an efficient envelope. Glazing percentage was $26.8 \%$, and the architects chose a simple rectangular shape to minimize exterior heat transfer surfaces.

\section{Lighting}

The average LPD of the school is $0.68 \mathrm{~W} / \mathrm{ft}^{2}, 43 \%$ lower than the code maximum of $1.2 \mathrm{~W} / \mathrm{ft}^{2}$. Daylighting also helped reduce the energy consumed by the lighting. A raised clerestory lines the spine of the building, interior and exterior light shelves enhance daylighting for the south-facing classrooms, and tubular lighting brings light into the upper-level, north-facing classrooms. T8 lamps provide the electric lighting because LEDs were not economically feasible at the time of construction.

\section{Monitoring System}

The building employs a building automation system.

\section{Occupancy Engagement}

The designers took special care to make the school's sustainability features visible to students. Certain hallways expose key features, such as the pipes coming from the water source heat pump well field; and monitoring stations allow students to keep tabs on the project's performance, such as the amount of water collected and filtered by on-site bioswales. In addition, there is an outdoor weather classroom so that students can monitor the weather and see how conditions impact the building's performance.

"The students can tell you more about geothermal energy than most adults could," says Stanfield. "When you are thinking about net zero energy, it is not only about designing the building-you have got to have buy-in on the operation side. The numbers will not be as good if you don't have a champion, and in this school, the kids are the champions."

\section{Renewable Energy}

Renewable energy is supplied by a $208-\mathrm{kW}$, thin-film PV array located on the roof and $140 \mathrm{~kW}$ of crystalline panels installed on top of a parking area shade structure. The system has an expected 20-year lifespan; and because the output of the panels is expected to decrease over time, the system was sized so that generation at year 10 would match consumption. 


\section{Getting to Zero}

\section{Definition Used to Achieve Zero Energy Status}

Part of what made the installed solar on this project economically feasible was a program set up by the Tennessee Valley Authority to encourage on-site renewable energy generation. The final program initially paid $\$ 0.12$ per kilowatt-hour $(\mathrm{kWh})$ more than the selling price for each $\mathrm{kWh}$ of renewable energy generated. In exchange, Warren County Public Schools relinquished the solar renewable energy certificates to the Tennessee Valley Authority. This practice means that Richardsville does not qualify as a zero energy school according to the DOE definition.

In addition, recent data indicate that the school did not completely offset its annual delivered energy with on-site renewable production in the most recent 12-month period; however, that data set was pulled during one of the worst winters on record in the area, says Stanfield, so energy production was hampered. The school did operate at zero energy in the previous four years, according to Stanfield.

A source energy calculation follows:

Source energy $=($ annual delivered energy x 3.15) $-($ annual site-generated energy $\times 3.15)$

Source energy $=(433,809 \times 3.15)-(404,273 \times 3.15)=93,038 \mathrm{kWh}$

\section{Energy Strategies at a Glance}

Energy strategies at Richardsville Elementary include:

- Incorporate education opportunities in occupant engagement for the students.

- Improve the efficiency of the DOAS.

- Size the PV array for decreased production throughout time.

\section{Costs}

\section{Total Project Costs}

The total project cost for Richardsville Elementary was $\$ 14,927,000$, or $\$ 206.50 / \mathrm{ft}^{2}$.

\section{Incremental Costs}

The project team developed a financial model to determine a return on investment for a zero energy school compared to a conventional school to demonstrate the feasibility of the project to the school district and legislators. The Kentucky Department of Energy reported that new schools in Kentucky typically consumed $65 \mathrm{kBtu} / \mathrm{ft}^{2} \cdot \mathrm{yr}$, which amounts to approximately $\$ 2$ million per year in energy costs throughout the state. Richardsville energy costs were estimated to be only $\$ 857,037$ per year, and solar generation was estimated to bring in $\$ 1,565,713$ in revenue. That adds up to $\$ 2,735,680$ in annual savings and revenue generated for the school, enabling the project to fall within the 15 -year simple payback mandated by the school district for approval.

To meet that threshold, "We had to be less than $\$ 206$ per $\mathrm{ft}^{2}$," says Stanfield. "And we came in at $\$ 203$ per $\mathrm{ft}^{2}$ even with solar panels." 


\section{Lessons Learned}

Stanfield reflects that the biggest change since Richardsville opened has been the growing affordability of LED lighting, making daylighting a tougher sell. The low energy use and attractive prices mean that a better return on investment is within reach compared to the days when passive daylighting strategies were the only feasible option if you were aiming for zero energy.

Stanfield looks forward to a day when energy storage is possible at the scale of a school. "Right now, all of our buildings are completely grid tied," he says. "In order for the project to make financial sense, we have to sell every bit of the energy we generate."

\subsection{Sandy Grove Middle School}

Through an innovative public-private arrangement, the architectural firm designing this school became owner and operator and transformed a conventional design into a building that produces nearly $30 \%$ more energy than it consumes. The arrangement encouraged enhanced commissioning, which has resulted in continuous improvement, especially in leveling peak demand. Table 33 and Table 34 summarize information about the school.

Table 33. Sandy Grove Middle School at a Glance

\begin{tabular}{ll}
\hline Characteristic & Value \\
\hline Location & Lumber Ridge, NC \\
Climate zone & Zone 4, Mixed Humid \\
Owner & Firstfloor \\
Building type & Middle school \\
Number of occupants & 650 students \\
Gross floor area & $75,930 \mathrm{ft}^{2}$ \\
New or renovation & New \\
Date of completion & September 2013 \\
Annual source energy with renewables & $712,555 \mathrm{kWh}$ \\
Annual delivered energy & $542,492 \mathrm{kWh}$ \\
Renewable energy generated annually on-site & $768,700 \mathrm{kWh}$ \\
Site EUl & $24.38 \mathrm{kBtu} / \mathrm{ft}^{2} \cdot \mathrm{yr}$ \\
\hline
\end{tabular}

Table 34. Sandy Grove Middle School Ratings and Awards

\begin{tabular}{ll}
\hline Program & Year \\
\hline $\begin{array}{l}\text { ASHRAE Region IV Technology Award First Place for New Educational } \\
\text { Facilities }\end{array}$ & 2015 \\
$\begin{array}{l}\text { American Institute of Architects Eastern North Carolina Honor Award } \\
\text { (Service Category) }\end{array}$ & 2014 \\
$\begin{array}{l}\text { Construction Professionals Network of NC Star Award } \\
\text { North Carolina Schools Boards Association Award for Excellence in }\end{array}$ & 2014 \\
Architectural Design & 2013 \\
\hline
\end{tabular}

\section{Design Process}

The school's layout was originally established in 2006 as a "no frills" program. It was then put on hold for a few years until financing became available; however, district officials still had a 
problem: they estimated that a new school would cost $\$ 1.5$ million in annual operating expenses, but their budget was capped at $\$ 450,000$.

"It was really a desperate situation," reflects Robbie Ferris AIA, president of SfL+a, the architecture firm that designed the project. "They needed a new building, so we had to find a way to deliver the building at that cost."

The solution ended up being a private-public partnership in which a developer arm of SfL $+\mathrm{a}$ called Firstfloor owns the building and leases it to the county for $\$ 450,000$ per year (see more about this partnership in the "Costs" section). However, to ensure that Firstfloor does not lose money on the deal, the building needs to operate at zero energy or better. Overnight, the design program changed from "no-frills" to "zero energy," and the design team had a much bigger stake in the outcome.

With a few years of operation under his belt, Ferris says the arrangement has been transformational for his company and the pace of innovation. "We own it, we operate it, and therefore we are learning from it. We have gone from what was a five- or six-year cycle of innovation to a six-month cycle of innovation."

\section{Energy Strategies}

\section{Heating, Ventilating, and Air Conditioning}

Each classroom has its own dedicated water source heat pump, ultimately requiring 160300 -ftdeep wells. This system delivers $55^{\circ} \mathrm{F}$ water to the heat pumps so that less energy is used to meet indoor conditioning needs. Further, the school's thermostats are engineered with a $4^{\circ} \mathrm{F}$ temperature range. Teachers have the ability to move the range up or down, granting a sense of occupant control, but the flexibility to vary a few degrees means that the system switches on less often, saving energy. Ventilation is controlled by carbon dioxide sensors throughout the building, which bring in more or less outdoor air based on occupancy.

\section{Envelope}

The building's design is essentially a duplicated whole-building air barrier, with both concrete masonry construction and a continuous layer of closed-cell polyurethane spray foam. R-29 rigid insulation was chosen for the roof, compared to a baseline of R-20; however, the design team knew that airtightness would ultimately depend on the craftsmanship of the details. To aid with installation, SfL + a created an 8-ft mock-up wall and a three-dimensional layering model to demonstrate the details and flashing specifications. Then they made on-site visits to hold preparatory meetings, answer questions, and check details.

\section{Power}

Several 20-ft-high solar trees (pictured above) along with 2,358 roof-mounted PV panels generated more than 768,700 kWh of electricity last year, exceeding Sandy Grove's power needs by approximately $30 \%$. The PV system was oversized to mitigate utility demand charges and because rate structures were uncertain at the time of design. 


\section{Monitoring Systems and Occupancy Engagement}

The school showcases its performance through an energy dashboard, which shows real-time electrical consumption, PV production, water use, and geothermal performance. Sandy Grove teachers designed 20 hours of instruction around the dashboard for each grade level, allowing the project to apply for a LEED $^{\circledR}$ green building program innovation credit (the project's LEED ${ }^{\circledR}$ $\mathrm{BD}+\mathrm{C}$ : Schools v3 application is still pending). Further, the project team set up the dashboard to monitor each building wing separately so that the grades can compete with each other to reduce energy use. Figure 51 shows an end-use breakdown of the energy loads.

\section{Getting to Zero}

\section{Qualifying for DOE Zero Energy Status}

This project meets all the requirements of the DOE definition for a ZEB. The energy delivered to the site exceeds the energy consumed at the site on a source energy basis and the renewable energy certificates are retained by Firstfloor.

To calculate the source energy for this all-electric building, both the delivered and renewably produced energy use a site-to-source energy conversion factor of 3.15 :

Source energy $=($ annual delivered energy x 3.15) $-($ annual exported energy $\mathrm{x} 3.15)$

Source energy $=(542,492 \mathrm{kWh} \times 3.15)-(768,700 \mathrm{kWh} \times 3.15)=-712,555 \mathrm{kWh}$

\section{End Use Breakdown}

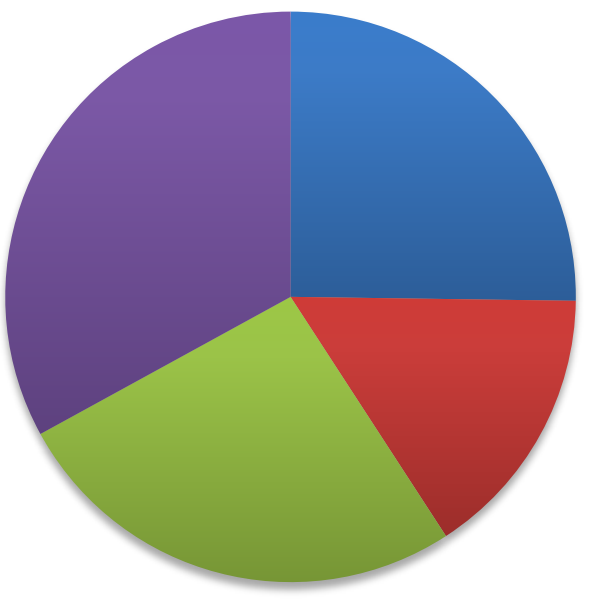

- Lighting 136,824 kWh

-Plug Load 84,671 kWh

- HVAC 142,076 kWh

- Other $178,921 \mathrm{kWh}$

Figure 51. Sandy Grove Middle School end-use breakdown

Note: Because the energy dashboard was set up for student competitions, some office and kitchen spaces are not captured in the end-use breakdown, but they are captured in the building total; therefore the "other" column is larger than typical. 


\section{Energy Strategies at a Glance}

Energy strategies at Sandy Grove Middle School include:

- Ensure that the building envelope is detailed correctly, and monitor installation.

- Balance occupant control and energy efficiency by implementing a wide dead-band temperature range.

- Oversize the PV system to allow for rate changes. (Note that this is not important for reaching zero energy status, but is important for minimizing the risk of utility rate changes that could impact the goal of zero utility costs.)

\section{Incremental Costs}

Although this project had an original "no frills" design, no incremental cost data notes a difference between the original and the final, net-positive design; however, Ferris notes that internal SfL + a studies have shown that zero energy buildings cost only $2 \%$ more than conventional buildings. "These things are really hard to quantify, but we're seeing it doesn't take all that much more," says Ferris.

\section{Lessons Learned}

The biggest lesson learned stemmed from the designer taking on the duties and responsibilities of the facility operator. Firstfloor enlisted the help of consultant Brady Trane to provide monitoring-based commissioning services for a very extensive optimization process, and as a result Firstfloor was able to reduce demand by $40 \%$ and consumption by $20 \%$ in addition to the very high-performing building design.

The building was originally designed to peak at $450 \mathrm{~kW}$, but it is now typically peaking at $130 \mathrm{~kW}$ or possibly $150 \mathrm{~kW}$ on the coldest days, according to Ferris. Most of that was achieved through preheating and cooling the building, a strategy that has informed many projects since. For current projects, "The new goal is to have the same consumption during the day as during the night, [in effect] using the building itself to store energy," says Ferris. "If you can eliminate the peak, it changes everything."

Briefly, the most effective strategies for achieving zero energy were:

- Optimizing start and stop times to level peak demand to help manage utility costs

- Engaging monitoring-based commissioning services.

\subsection{Lady Bird Johnson Middle School}

Lady Bird Johnson Middle School proves that being big and being urban is not a disqualifying factor for aiming for zero energy. This $152,250-\mathrm{ft}^{2}$ school in Irving, Texas, uses extensive shading to minimize solar heat gain and incorporates wind turbines as a part of its on-site renewable energy generation portfolio. Incremental costs on this project were high, but this school was a trailblazer that paved the way for more affordable solutions. Table 35 and Table 36 show summary information about the school. 
Table 35. Lady Bird Johnson Middle School at a Glance

\begin{tabular}{ll}
\hline Characteristic & Value \\
\hline Location & Irving, TX \\
Climate zone & Zone 3, Mixed Dry \\
Owner & Irving Independent School District \\
Building type & Middle school \\
Number of occupants & 1,170 \\
Gross floor area & $152,250 \mathrm{ft}^{2}$ \\
Stories & Two \\
New or renovation & New \\
Date of completion & September 2011 \\
Annual source energy with renewables & $5,400 \mathrm{kWh}$ \\
Annual delivered energy & $762,600 \mathrm{kWh}$ \\
Renewable energy generated annually on-site & $764,300 \mathrm{kWh}^{\mathrm{a}}$ \\
Site EUI & $17 \mathrm{kBtu} / \mathrm{ft}^{2} \cdot \mathrm{yr}$ \\
EUI with renewables & $-0.04 \mathrm{kBtu} / \mathrm{ft}^{2} \cdot \mathrm{yr}$ \\
\hline
\end{tabular}

${ }^{a}$ Actual data from 2012 calendar year. These values were geometrically estimated from a bar graph, accuracy to approximately $+/-1,000 \mathrm{kWh}$.

Table 36. Lady Bird Johnson Middle School Ratings and Awards

\begin{tabular}{ll}
\hline Program & Year \\
\hline LEED $^{\text {TM }}$ New Construction & 2011 \\
Caudill Award: Texas Association of School Administrators & 2012 \\
Short List for the International Green Building Awards & 2012 \\
\hline
\end{tabular}

\section{Design Process}

The project began with the goal of designing a zero energy facility, so the design team set out to determine how much energy consumption would need to be reduced to make the cost and size of a solar array feasible. The team determined a reduction of $50 \%$ compared to a conventional building would suffice and began exploring sustainable energy strategies.

One of the biggest hurdles was the building site. Much of the surrounding land was developed, leaving a long, skinny plot to work with, oriented north-south, with a small entry point on the south end and a drainage floodplain stretching along the west side. The entry location forced the building into a north-south orientation, which was not optimal for reducing heat loads from the Texas sun. As a remedy, a large overhanging canopy was designed to highlight the main entrance and to provide shading at the south face of the building. This large canopy also runs the length of the building along the west side, shading the second-story classroom windows throughout the school day. The second floor on the west side provides an overhang to the firstfloor classrooms, extending the shading to the first floor. This design helps avoid solar heat gain while allowing natural light to enter the classrooms.

\section{Energy Strategies \\ Heating, Ventilating, and Air Conditioning}

The project employs 468 wells - each 250-ft deep-to supply 105 ground source water-to-water heat pumps that are used for the school's air-conditioning and heating needs. The closed-loop 
system uses water to transfer heat from the building to ground during the summer months and from ground to the building during the winter months, reducing HVAC energy use by $30 \%$ compared to a traditional central plant system. ERVs allow fresh air into the building while recapturing the heating or cooling from the conditioned air to optimize efficiencies.

\section{Envelope}

The building has a structural steel frame with brick and metal panel veneers. Increased wall and roof insulation bring $\mathrm{R}$-values to $\mathrm{R}-25$ and $\mathrm{R}-32$, respectively.

\section{Monitoring Systems}

A monitoring system displays energy data in real time, which offers opportunities to teach students about energy.

\section{Occupancy Engagement}

To maximize the learning potential, Corgan Associates, the Dallas-based firm that led the design team, worked with the faculty to devise ways for the project to support the science curriculum. For example, an additional stairway was incorporated during the design phase for students to access a rooftop observation deck for a close look at the PV array.

Touch screens, an interactive learning museum display in the main corridor, a learning lab, and an observation window into the inverter room are some other features incorporated for teaching purposes.

\section{Power}

The school has $300 \mathrm{~kW}$ of installed Solyndra panels and $300 \mathrm{~kW}$ of installed Kyocera panels. The Solyndra panels contain cylindrical tubes that are installed slightly above the white roof and capture sunlight from 360 degrees. Combined, the solar array is designed to generate $99 \%$ of the school's electricity, approximately $850,000 \mathrm{kWh}$ each year for the system's anticipated lifespan of 20-25 years. The remaining $1 \%$ is produced by 12 wind turbines, which are installed on top of 45-ft towers along the west side of the building. This renewable energy is first directed to meet demands on the site, and any surplus energy is sent back to the regional electric grid for the local utility company to purchase.

\section{Getting to Zero}

\section{Definition Used to Achieve Zero Energy Status}

Lady Bird Johnson Middle School was verified zero energy in 2012, when 12 months of data showed that on-site production offset consumption; however, in the most recent 12-month period of data available (2013-2014), the school did not achieve the goal. The solar array was in repair for two months of this data set and experienced a loss of production, but even if solar production is predicted from similar months, consumption outweighs production by approximately $2 \%$.

The most notable change from 2012 to 2013 was a large consumption spike in August, whereas there had been very low consumption the year before. This is likely due to either new summer programming in August or a mechanical system failure. In either case, the data set highlights the fact that many zero energy schools depend on the summer months for high renewable energy production and low energy consumption. A change in programming or an unexpected energy 
demand can disrupt that balance, and more solar panels may need to be added, or more efficiency achieved, if the school is to remain zero energy.

\section{Energy Strategies at a Glance}

Energy strategies used at Lady Bird Johnson Middle School include:

- Shading minimizes solar heat gain.

- Wind turbines supply electricity but only a very small proportion compared to solar.

\section{Calculations}

Source energy:

(Annual delivered energy x 3.15) - (annual site-generated energy x 3.15)

$(762,600 \times 3.15)-(764,300 \times 3.15)=-5,400 \mathrm{kWh}$

Site EUI (building energy use):

(annual delivered energy in $\mathrm{kWh} \times 3.412$ ) / (building area in $\mathrm{ft}^{2}$ )

$(762,600 \times 3.412) / 152,250=17 \mathrm{kBtu} / \mathrm{ft}^{2} \cdot \mathrm{yr}$

EUI with renewables (building energy minus on-site renewable energy generated):

((annual delivered energy in $\mathrm{kWh} \times 3.412)$ - (on-site renewable energy generated annually in $\mathrm{kWh} \times 3.412)$ ) / (building area in $\mathrm{ft}^{2}$ )

$$
((762,600 \times 3.412)-(764,300 \times 3.412)) / 152,250=-0.04 \mathrm{kBtu} / \mathrm{ft}^{2} \cdot \mathrm{yr}
$$

\section{Costs}

\section{Total Project Costs}

The total project cost was $\$ 29,610,423$.

\section{Incremental Costs}

In pursuit of the zero energy goal, officials agreed to spend $12.5 \%$ of Lady Bird Johnson Middle School's construction budget on high-performance design strategies and energy-efficient technologies. According to Corgan Associates, those up-front costs totaled \$3.7 million, with most $(\$ 2,976,972)$ used to purchase the PV panels. The cost of PV panels has since decreased, making such options more financially feasible.

\section{Lessons Learned}

Lady Bird Johnson Middle School was the largest zero energy public school in the country at the time it was completed, and it proved that zero energy strategies could scale. But the progress is continuous, the design team is careful to note. A mechanical system that is left on or a change to the building's program during the summer could have huge consequences for reaching the zero energy goal from one year to another; thus, the building needs to be carefully monitored and adaptable enough to respond to changing needs during the school's lifetime. 


\subsection{Valley View Middle School}

By replacing a school built in the 1980s and using the Living Building Challenge as a guideline, the Snohomish School District was able to build a building twice the size as the replaced school with roughly the same energy use. The new Valley View Middle School building does not yet have solar panels on the roof, but because it was designed with a zero energy goal in mind, the district is benefitting from the extremely low energy costs that come with an EUI of 22.4 $\mathrm{kBtu} / \mathrm{ft}^{2} \cdot \mathrm{yr}$. Summary data is shown in Table 37 and Table 38.

Table 37. Valley View Middle School at a Glance

\begin{tabular}{ll}
\hline Characteristic & Value \\
\hline Location & Snohomish, WA \\
Climate zone & Zone 5, Marine \\
Owner & Snohomish School District \\
Building type & Middle school \\
Number of occupants & 1,050 \\
Gross floor area & $168,000 \mathrm{ft}^{2}$ \\
Stories & Three \\
New or renovation & New \\
Date of completion & September 2012 \\
Annual source energy with renewables & $3,474,310 \mathrm{kWh}$ \\
Annual delivered energy & $1,103,569 \mathrm{kWh}$ \\
Renewable energy generated annually on-site & $0 \mathrm{kWh}$ \\
Site EUI & $22.39 \mathrm{kBtu} / \mathrm{ft}^{2} \cdot \mathrm{yr}$ \\
EUl with renewables & $22.39 \mathrm{kBtu} / \mathrm{ft}^{2} \cdot \mathrm{yr}$ \\
\hline
\end{tabular}

Table 38. Valley View Middle School Ratings and Awards

\begin{tabular}{ll}
\hline Program & Year \\
\hline ASHRAE National Technology Award & 2015 \\
American School \& University Magazine Outstanding Design Award, Educational Interiors & 2015 \\
Showcase & 2014 \\
Excellence in Masonry Design Award-Merit Award K-12 & 2015 \\
\hline
\end{tabular}

\section{Design Process}

Early in the visioning process, the community and staff pushed the design team to use the Living Building Challenge as a guideline for the project. "They wanted to pursue sustainability as hard as they could," recalls Tim Jewett, principal at Dykeman, the lead architect for the project. The school was in the position of having a bond that was budgeted in 2006 when there was high escalation, so they had an unusually high construction budget for a project going to bid in 2010 . "The challenge from the get-go was 'see what you can do with the budget you have,"” says Jewett.

That lofty challenge called for a closely integrated team and several rounds of energy modeling. In the end, the team came up with a design with a projected EUI in the target range for zero energy and a PV system that was bid within budget, but the school decided not to purchase the solar panels and use that money elsewhere. Although it is not yet zero energy, the school is performing at an impressive efficiency threshold. 


\section{Energy Strategies}

\section{Heating, Ventilating, and Air Conditioning}

The project uses a ground source water-to-water heat pump, combined with displacement ventilation, which requires very tight discharge air temperature control. Although this system must treat a larger load of air, it heats or cools only to temperatures near the ambient temperature, requiring less energy.

Displacement ventilation also has the benefit of introducing fresh air near occupant height, which allows pollutants to rise to the ceiling level for removal. These systems can achieve up to 50\% better air quality compared to overhead air distribution systems, and, according to Dykeman's own tracking of schools in which such systems have been installed, they correlate with 3\%-6\% improvement in class attendance.

The project also uses radiant floors in the library and administrative offices with hydronic heating water convectors to supply heat at the perimeter.

\section{Envelope}

The envelope consists of an 8-in. metal stud wall with 4 in. of rigid rock wool board. A freely vented rain screen is hung throughout, and a curtainwall system was selected that provides a Uvalue of 0.15 . The tricky thing about the design, according to Jewett, was trying to ensure a full thermal break around the entire perimeter and minimize thermal bridges. Zinc panels and brick cladding finish off the envelope, and they were chosen for their durability.

\section{Monitoring Systems}

The school's monitoring system was set up to group two classroom clusters per floor, resulting in six separately metered areas. This allows the students to compete against each other to minimize energy use.

\section{Feedback Technology}

A relatively unique feature of the design is that the exhaust fans in the bathrooms and copy rooms are linked with the occupancy sensors that control the lighting. This helps ensure that the fans run only when those rooms are being used. Fan systems that serve multiple spaces have dampers to close off the areas that are not occupied and motors that adjust the fan speed for different volumes of air.

\section{Renewable Energy}

The design incorporates infrastructure for a $960-\mathrm{kW}$ PV array to be installed on the roof at a future date. It is projected that such a system would offset the school's current amount of annual delivered energy.

\section{Lighting}

Designers sought to minimize energy use through integrated lighting and shading. LED fixtures equipped with occupancy sensors provide electrical lighting, whereas daylight harvesting is combined with automated dimming controls and motorized shades. Interestingly, the designers chose an upside-down U-shape for the exposed glazing in the classrooms because daylighting models showed hot spots occurring in the center of the classroom. The center of the "U" now 
allows for more wall space, which Jewett says the teachers highly value for whiteboards and display areas.

\section{Definition Used to Achieve Zero Energy Status}

This project does not meet the DOE definition of zero energy because it does not incorporate any renewable energy production on-site; however, the project does achieve the kind of significant energy efficiency that is needed for a reasonably-sized on-site PV array to meet the building's needs.

\section{Calculations}

Source energy:

(Annual delivered energy x 3.15) - (annual site-generated energy x 3.15)

$$
(1,102,631 \mathrm{kWh} \times 3.15)+(938 \mathrm{kWh} \times 1.09)=3,474,310 \mathrm{kWh}
$$

Site EUI (building energy use):

(Annual delivered energy in $\mathrm{kWh} \times 3.412$ ) / (building area in $\mathrm{ft}^{2}$ )

$$
(1,103,569 \times 3.412) / 168,000=22.41 \mathrm{kBtu} / \mathrm{ft}^{2} \cdot \mathrm{yr}
$$

EUI with renewables (building energy minus on-site renewable energy production):

((Annual delivered energy in kWh x 3.412) - (on-site renewable energy generated in $\mathrm{kWh} \times 3.412)$ ) / (building area in $\mathrm{ft}^{2}$ )

$$
((762,600 \times 3.412)-(0 \times 3.412)) / 168,000=22.39 \mathrm{kBtu} / \mathrm{ft}^{2} \cdot \mathrm{yr}
$$

\section{Energy Strategies at a Glance}

To minimize energy use, Valley View Middle School:

- Uses water-to-water heat pumps combined with displacement ventilation to provide optimal air quality at high energy efficiency

- Minimizes thermal bridges in the building envelope

- Uses occupancy sensors for exhaust fans as well as electric lighting.

\section{Costs}

The total project cost was $\$ 53,000,000$.

\section{Incremental Costs}

A total cost analysis determined that the district would end up spending less money on annual utility and maintenance costs compared to a baseline alternative and ASHRAE 90.1. The Washington State 30-year life-cycle cost analysis helped inform the selection of the most costeffective systems. 


\section{Lessons Learned}

Jewett says the experience shows what kind of outcomes can be achieved when the team is asked to "design to the full extent of the budget and the owner pushes the design team to be fully integrated"; however, he cautions, "If you are really trying to save energy, you have to allow yourself time on the design side to do the planning." That time is important not only for finding design solutions but also for getting buy-in from the district and the client. 


\section{Conclusions}

It is possible for $\mathrm{K}-12$ new construction projects to achieve zero energy in all climate zones throughout the continental United States. This feasibility study was developed with input and guidance from a panel of industry experts. It includes:

- Target EUIs for owners, designers, and engineering firms to help achieve zero energy K12 schools

- A pathway for how to achieve these EUIs by climate zone, including values for the building envelope, fenestration, lighting systems (including electrical lights and daylighting), HVAC systems, building automation and controls, outdoor air treatment, and SWH.

NREL's primary tasks in the development of this feasibility study were to provide the analysis and modeling support to verify energy savings and to present a pathway to meet the zero energy goal. This feasibility study also provides the technical details that were used to determine zero energy targets, including model inputs and assumptions. The specific objectives of this feasibility study were to:

- Document the EnergyPlus and OpenStudio modeling assumptions used to establish EUI targets that make zero energy goals possible.

- Document the zero energy simulation school models.

- Provide target EUIs by climate zone that can be used to achieve zero energy in schools.

- Document limitations in the OpenStudio workflows that, if remedied, would greatly simplify the process of evaluating design strategies that move a building toward zero energy.

In many ways, this feasibility study is a simple interface to a complex analysis performed using EnergyPlus. The combination of strategies contained in a single table should help facilitate increased energy efficiency in new buildings. Case studies of actual $\mathrm{K}-12$ school applications strengthen the business case for taking advantage of these energy-efficiency opportunities. 


\section{References}

ASHRAE. 2007. American National Standards Institute (ANSI)/ASHRAE Standard 62.1-2007Ventilation for Acceptable Indoor Air Quality. Atlanta, GA.

https://www.ashrae.org/home/search?k=Standard\%2062.1-2007.

ASHRAE. 2009. ASHRAE Handbook-Fundamentals. Atlanta, GA.

ww.slideshare.net/virginiavenus/2009-ashrae-

handbookfundamentalsinchpoundeditionashrae2009.

ASHRAE. 2012. Advanced Energy Design Guide for K-12 School Buildings: Achieving 50\% Energy Savings toward a Net Zero Energy Building. Atlanta, GA.

https:/www.ashrae.org/standards-research--technology/advanced-energy-design-guides/50percent-aedg-free-download.

ASHRAE. 2013a. ANSI/ASHRAE Standard 55-2013-Thermal Environmental Conditions for Human Occupancy. Atlanta, GA. https://www.ashrae.org/resources-publications/bookstore/standard-55.

ASHRAE. 2013b. ANSI/ASHRAE/ Illuminating Engineering Society of North America (IESNA) Standard 90.1-2013-Energy Standard for Buildings Except Low-Rise Residential Buildings. Atlanta, GA. https://www.ashrae.org/resources--publications/bookstore/standard-90-1.

ASHRAE. 2014. ANSI/ASHRAE Standard 105-2014-Standard Methods of Determining, Expressing, and Comparing Building Energy Performance and Greenhouse Gas Emissions. Atlanta, GA.

http://webstore.ansi.org/FindStandards.aspx?SearchString=ANSI\%2fASHRAE+Standard+105$2014 \&$ SearchOption $=0 \&$ PageNum $=0 \&$ SearchTermsArray $=$ null $\%$ 7cANSI $\% 2$ fASHRAE + Standa $\mathrm{rd}+105-2014 \% 7$ cnull.

Bonnema, Eric, Matthew Leach, Shanti Pless, and Paul Torcellini. 2013. Development of the Advanced Energy Design Guide for K-12 Schools-50\% Energy Savings. (Technical Report NREL/TP-5500-51437). Golden, CO: National Renewable Energy Laboratory (NREL). www.nrel.gov/docs/fy13osti/51437.pdf.

Briggs, Robert S., Robert G. Lucas, and Z. Todd Taylor. 2003. "Climate Classification for Building Energy Codes and Standards: Part 1-Development Process." ASHRAE Transactions 109(1): 121. www.techstreet.com/ashrae/products/1716114.

Deru, Michael, Kristin Field, Daniel Studer, Kyle Benne, Brent Griffith, Paul Torcellini, Bing Liu, Mark Halverson, Dave Winiarski, Michael Rosenberg, Mehry Yazdanian, Joe Huang, and Drury Crawley. 2011. U.S. Department of Energy Commercial Reference Building Models of the National Building Stock (Technical Report NREL/TP-5500-46861). Golden, CO: National Renewable Energy Laboratory. www.nrel.gov/docs/fy11osti/46861.pdf.

DOE. 2003. "Map of DOE's Proposed Climate Zones."

https://basc.pnnl.gov/sites/default/files/IECC\%20climate\%20zone\%20map_Revised_20.jpg. 
DOE. 2014. “Commercial Prototype Building Models.” Last modified July 23. https://www.energycodes.gov/commercial-prototype-building-models.

DOE. 2015a. A Common Definition for Zero Energy Buildings (Technical Report DOE/EE1247). Washington, D.C.

http://energy.gov/sites/prod/files/2015/09/f26/bto_common_definition_zero_energy_buildings_0 93015.pdf.

DOE. 2015b. "EnergyPlus Energy Simulation Software, Version 8.4." Last updated September 30, 2015. https://energyplus.net.

Fox, Erin. 2005. "Tracking U.S. Trends: State Data Tables_-Access to Technology." Education Week 24 (May 5):35. www.edweek.org/media/pdf/tc05/35access-t1.pdf.

Griffith, Brent, Paul Torcellini, Nicholas Long, Drury Crawley, and John Ryan. 2006.

"Assessment of the Technical Potential for Achieving Zero-Energy Commercial Buildings:

Preprint" (Conference Paper NREL/CP-550-39830). Paper presented at ACEEE Summer Study, Pacific Grove, California, August 14-18. www.nrel.gov/docs/fy06osti/39830.pdf.

Guglielmetti, Rob, Dan Macumber, and Nicholas Long. 2011. "OpenStudio: An Open Source Integrated Analysis Platform: Preprint” (Conference Paper NREL/CP-5500-51836). Paper presented at Building Simulation 2011 Sydney, Australia, November 14-16. www.nrel.gov/docs/fy12osti/51836.pdf.

Judkoff, Ron, and Joel Neymark. 1995. International Energy Agency Building Energy Simulation Test (BESTEST) and Diagnostic Method (Technical Report NREL/TP-472-6231). Golden, CO: National Renewable Energy Laboratory. www.nrel.gov/docs/legosti/old/6231.pdf.

Leach, Matt, Eric Bonnema, Shanti Pless, and Paul Torcellini. 2012. "Setting Whole-Building Absolute Energy Use Targets for the K-12 School, Retail, and Healthcare Sectors: Preprint" (Conference Paper NREL/CP-5500-55131). Paper presented at ACEEE Summer Study on Energy Efficiency in Buildings, Pacific Grove, California, August 12-17. www.nrel.gov/docs/fy12osti/55131.pdf.

Meyer, Jason, Dominique Pride, Jonathan O'Toole, Colin Craven, and Vanessa Spencer. 2011. Ground-Source Heat Pumps in Cold Climates: The Current State of the Alaska Industry-A Review of the Literature, a Preliminary Economic Assessment, and Recommendations for Research (Technical Report). Fairbanks, AK: Alaska Center for Energy and Power. http://www.uaf.edu/files/acep/Ground-Source-Heat-Pumps-in-Cold-Climates.pdf.

Pless, Shanti, Paul Torcellini, and Nicholas Long. 2007. Technical Support Document: Development of the Advanced Energy Design Guide for K-12 Schools-30\% Energy Savings (Technical Report NREL/TP-550-42114). Golden, CO: National Renewable Energy Laboratory. www.nrel.gov/docs/fy07osti/42114.pdf.

Skutt. 2012. “KM-1227-3 Kiln.” Accessed November 2012. www.skutt.com/products/km-12273-3ph.html. 


\section{Appendix A. Schedule Tabular Data}

Table 39. Library/Media Center Occupancy Schedule

\begin{tabular}{|c|c|c|c|c|c|c|c|c|c|c|c|c|c|c|c|c|c|c|c|}
\hline \multirow{2}{*}{ Schedule } & \multicolumn{19}{|l|}{ Hour } \\
\hline & $1-5$ & 6 & 7 & 8 & 9 & 10 & 11 & 12 & 13 & 14 & 15 & 16 & 18 & 19 & 20 & 21 & 22 & 23 & 24 \\
\hline $\begin{array}{l}\text { School } \\
\text { weekdays }\end{array}$ & 0.00 & 0.00 & 00 & 0.00 & 0.30 & 0.60 & 60 & 0.30 & 0.30 & 0.60 & .60 & 0.30 & 0.30 & 0.00 & 0.00 & 0.00 & 0.00 & 0.00 & 0.00 \\
\hline $\begin{array}{l}\text { Summer } \\
\text { weekdays }\end{array}$ & 0.00 & 0.00 & 0.00 & 0.00 & 0.00 & 0.00 & 0.00 & 0.00 & 0.00 & 0.00 & 0.00 & 0.00 & 0.00 & 0.00 & 0.00 & 0.00 & 0.00 & 0.00 & 0.00 \\
\hline $\begin{array}{l}\text { Other } \\
\text { days }\end{array}$ & 0.00 & 0.00 & 0.00 & 0.00 & 0.00 & 0.00 & 0.00 & 0.00 & 0.00 & 0.00 & 0.00 & 0.00 & 0.00 & 0.00 & 0.00 & 0.00 & 0.00 & 0.00 & 0.00 \\
\hline
\end{tabular}

Table 40. Primary School General Occupancy Schedule

\begin{tabular}{|c|c|c|c|c|c|c|c|c|c|c|c|c|c|c|c|c|c|c|c|}
\hline \multirow{2}{*}{ Schedule } & \multicolumn{19}{|c|}{ Hour } \\
\hline & $1-5$ & 6 & 7 & 8 & 9 & 10 & 11 & 12 & 13 & 14 & 15 & 16 & 18 & 19 & 20 & 21 & 22 & 23 & 24 \\
\hline $\begin{array}{l}\text { School } \\
\text { weekdays }\end{array}$ & 0.00 & 0.00 & 0.00 & 0.00 & 0.30 & 0.30 & 0.30 & 0.20 & 0.20 & 0.30 & 0.30 & 0.05 & 0.05 & 0.00 & 0.00 & 0.00 & 0.00 & 0.00 & 0.00 \\
\hline $\begin{array}{l}\text { Summer } \\
\text { weekdays }\end{array}$ & 0.00 & 0.00 & 0.00 & 0.00 & 0.00 & 0.05 & 0.05 & 0.05 & 0.05 & 0.00 & 0.00 & 0.00 & 0.00 & 0.00 & 0.00 & 0.00 & 0.00 & 0.00 & 0.00 \\
\hline $\begin{array}{l}\text { Other } \\
\text { days }\end{array}$ & 0.00 & 0.00 & 0.00 & 0.00 & 0.00 & 0.00 & 0.00 & 0.00 & 0.00 & 0.00 & 0.00 & 0.00 & 0.00 & 0.00 & 0.00 & 0.00 & 0.00 & 0.00 & 0.00 \\
\hline
\end{tabular}

Table 41. Primary School Cafeteria Occupancy Schedule

\begin{tabular}{|c|c|c|c|c|c|c|c|c|c|c|c|c|c|c|c|c|c|c|c|}
\hline \multirow{2}{*}{ Schedule } & \multicolumn{19}{|c|}{ Hour } \\
\hline & $1-5$ & 6 & 7 & 8 & 9 & 10 & 11 & 12 & 13 & 14 & 15 & 16 & 18 & 19 & 20 & 21 & 22 & 23 & 24 \\
\hline $\begin{array}{l}\text { School } \\
\text { weekdays }\end{array}$ & 0.00 & 0.00 & 0.00 & 0.15 & 0.05 & 0.05 & 0.05 & 0.70 & 0.70 & 0.05 & 0.05 & 0.15 & 0.15 & 0.15 & 0.00 & 0.00 & 0.00 & 0.00 & 0.00 \\
\hline $\begin{array}{l}\text { Summer } \\
\text { weekdays }\end{array}$ & 0.00 & 0.00 & 0.00 & 0.00 & 0.00 & 0.00 & 0.00 & 0.00 & 0.00 & 0.00 & 0.00 & 0.00 & 0.00 & 0.00 & 0.00 & 0.00 & 0.00 & 0.00 & 0.00 \\
\hline $\begin{array}{l}\text { Other } \\
\text { days }\end{array}$ & 0.00 & 0.00 & 0.00 & 0.00 & 0.00 & 0.00 & 0.00 & 0.00 & 0.00 & 0.00 & 0.00 & 0.00 & 0.00 & 0.00 & 0.00 & 0.00 & 0.00 & 0.00 & 0.00 \\
\hline
\end{tabular}


Table 42. Primary School Gym Occupancy Schedule

\begin{tabular}{|c|c|c|c|c|c|c|c|c|c|c|c|c|c|c|c|c|c|c|c|}
\hline \multirow{2}{*}{ Schedule } & \multicolumn{19}{|c|}{ Hour } \\
\hline & $1-5$ & 6 & 7 & 8 & 9 & 10 & 11 & 12 & 13 & 14 & 15 & 16 & 18 & 19 & 20 & 21 & 22 & 23 & 24 \\
\hline $\begin{array}{l}\text { School } \\
\text { weekdays }\end{array}$ & 0.00 & 0.00 & 0.00 & 0.00 & 0.15 & 0.15 & 0.15 & 0.15 & 0.15 & 0.15 & 0.00 & 0.15 & 0.15 & 0.15 & 0.05 & 0.05 & 0.05 & 0.00 & 0.00 \\
\hline $\begin{array}{l}\text { Summer } \\
\text { weekdays }\end{array}$ & 0.00 & 0.00 & 0.00 & 0.00 & 0.00 & 0.00 & 0.00 & 0.00 & 0.00 & 0.00 & 0.00 & 0.00 & 0.00 & 0.00 & 0.00 & 0.00 & 0.00 & 0.00 & 0.00 \\
\hline $\begin{array}{l}\text { Other } \\
\text { days }\end{array}$ & 0.00 & 0.00 & 0.00 & 0.00 & 0.00 & 0.00 & 0.00 & 0.00 & 0.00 & 0.00 & 0.00 & 0.00 & 0.00 & 0.00 & 0.00 & 0.00 & 0.00 & 0.00 & 0.00 \\
\hline
\end{tabular}

Table 43. Primary School Office Occupancy Schedule

\begin{tabular}{|c|c|c|c|c|c|c|c|c|c|c|c|c|c|c|c|c|c|c|c|}
\hline \multirow{2}{*}{ Schedule } & \multicolumn{19}{|c|}{ Hour } \\
\hline & $1-5$ & 6 & 7 & 8 & 9 & 10 & 11 & 12 & 13 & 14 & 15 & 16 & 18 & 19 & 20 & 21 & 22 & 23 & 24 \\
\hline $\begin{array}{l}\text { School } \\
\text { weekdays }\end{array}$ & 0.00 & 0.00 & 0.00 & 0.00 & 0.75 & .75 & 0.75 & 0.75 & .75 & .75 & 0.75 & 0.75 & .75 & .00 & 0.00 & 0.00 & 0.00 & 0.00 & 0.00 \\
\hline $\begin{array}{l}\text { Summer } \\
\text { weekdays }\end{array}$ & 0.00 & 0.00 & 0.00 & 0.00 & 0.00 & 0.25 & 0.25 & 0.25 & 0.25 & 0.00 & 0.00 & 0.00 & 0.00 & 0.00 & 0.00 & 0.00 & 0.00 & 0.00 & 0.00 \\
\hline $\begin{array}{l}\text { Other } \\
\text { days }\end{array}$ & 0.00 & 0.00 & 0.00 & 0.00 & 0.00 & 0.00 & 0.00 & 0.00 & 0.00 & 0.00 & 0.00 & 0.00 & .00 & 0.00 & 0.00 & 0.00 & 0.00 & 0.00 & 0.00 \\
\hline
\end{tabular}

Table 44. Secondary School General Occupancy Schedule

\begin{tabular}{|c|c|c|c|c|c|c|c|c|c|c|c|c|c|c|c|c|c|c|c|}
\hline \multirow{2}{*}{ Schedule } & \multicolumn{19}{|c|}{ Hour } \\
\hline & $1-5$ & 6 & 7 & 8 & 9 & 10 & 11 & 12 & 13 & 14 & 15 & 16 & 18 & 19 & 20 & 21 & 22 & 23 & 24 \\
\hline $\begin{array}{l}\text { School } \\
\text { weekdays }\end{array}$ & 0.00 & 0.00 & 0.00 & 0.00 & 0.50 & 0.45 & 0.45 & 0.20 & 0.20 & 0.45 & 0.05 & 0.05 & 0.05 & 0.00 & 0.00 & 0.00 & 0.00 & 0.00 & 0.00 \\
\hline $\begin{array}{l}\text { Summer } \\
\text { weekdays }\end{array}$ & 0.00 & 0.00 & 0.00 & 0.00 & 0.00 & 0.05 & 0.05 & 0.05 & 0.05 & 0.00 & 0.00 & 0.00 & 0.00 & 0.00 & 0.00 & 0.00 & 0.00 & 0.00 & 0.00 \\
\hline $\begin{array}{l}\text { Other } \\
\text { days }\end{array}$ & 0.00 & 0.00 & 0.00 & 0.00 & 0.00 & 0.00 & 0.00 & 0.00 & 0.00 & 0.00 & 0.00 & 0.00 & 0.00 & 0.00 & 0.00 & 0.00 & 0.00 & 0.00 & 0.00 \\
\hline
\end{tabular}


Table 45. Secondary School Cafeteria Occupancy Schedule

\begin{tabular}{|c|c|c|c|c|c|c|c|c|c|c|c|c|c|c|c|c|c|c|c|}
\hline \multirow{2}{*}{ Schedule } & \multicolumn{19}{|l|}{ Hour } \\
\hline & $1-5$ & 6 & 7 & 8 & 9 & 10 & 11 & 12 & 13 & 14 & 15 & 16 & 18 & 19 & 20 & 21 & 22 & 23 & 24 \\
\hline $\begin{array}{l}\text { School } \\
\text { weekdays }\end{array}$ & 0.00 & 0.00 & 0.00 & 0.15 & 0.00 & 0.00 & 0.00 & 0.95 & .95 & .00 & 0.00 & 0.00 & 0.00 & 0.00 & 0.00 & 0.00 & 0.00 & 0.00 & 0.00 \\
\hline $\begin{array}{l}\text { Summer } \\
\text { weekdays }\end{array}$ & 0.00 & 0.00 & 0.00 & 0.00 & 0.00 & 0.00 & 0.00 & 0.00 & 0.00 & 0.00 & 0.00 & 0.00 & 0.00 & 0.00 & 0.00 & 0.00 & 0.00 & 0.00 & 0.00 \\
\hline $\begin{array}{l}\text { Other } \\
\text { days }\end{array}$ & 0.00 & 0.00 & 0.00 & 0.00 & 0.00 & 0.00 & 0.00 & 0.00 & 0.00 & 0.00 & 0.00 & 0.00 & 0.00 & 0.00 & 0.00 & 0.00 & 0.00 & 0.00 & 0.00 \\
\hline
\end{tabular}

Table 46. Secondary School Gym Occupancy Schedule

\begin{tabular}{|c|c|c|c|c|c|c|c|c|c|c|c|c|c|c|c|c|c|c|c|}
\hline \multirow{2}{*}{ Schedule } & \multicolumn{19}{|c|}{ Hour } \\
\hline & $1-5$ & 6 & 7 & 8 & 9 & 10 & 11 & 12 & 13 & 14 & 15 & 16 & 18 & 19 & 20 & 21 & 22 & 23 & 24 \\
\hline $\begin{array}{l}\text { School } \\
\text { weekdays }\end{array}$ & 0.00 & 0.00 & 0.00 & 0.00 & 0.00 & 0.02 & 0.02 & 0.02 & 0.02 & 0.02 & 0.04 & 0.04 & 0.04 & 0.04 & 0.04 & 0.04 & 0.04 & 0.00 & 0.00 \\
\hline $\begin{array}{l}\text { Summer } \\
\text { weekdays }\end{array}$ & 0.00 & 0.00 & 0.00 & 0.00 & 0.00 & 0.04 & 0.04 & 0.04 & 0.04 & 0.04 & 0.04 & 0.00 & 0.00 & 0.00 & 0.00 & 0.00 & 0.00 & 0.00 & 0.00 \\
\hline $\begin{array}{l}\text { Other } \\
\text { days }\end{array}$ & 0.00 & 0.00 & 0.00 & 0.00 & 0.00 & 0.00 & 0.00 & 0.00 & 0.00 & 0.00 & 0.00 & 0.00 & 0.00 & 0.00 & 0.00 & 0.00 & 0.00 & 0.00 & 0.00 \\
\hline
\end{tabular}

Table 47. Secondary School Office Occupancy Schedule

\begin{tabular}{|c|c|c|c|c|c|c|c|c|c|c|c|c|c|c|c|c|c|c|c|}
\hline \multirow{2}{*}{ Schedule } & \multicolumn{19}{|l|}{ Hour } \\
\hline & $1-5$ & 6 & 7 & 8 & 9 & 10 & 11 & 12 & 13 & 14 & 15 & 16 & 18 & 19 & 20 & 21 & 22 & 23 & 24 \\
\hline $\begin{array}{l}\text { School } \\
\text { weekdays }\end{array}$ & 0.00 & 0.00 & 0.00 & 0.40 & 0.80 & 0.80 & 0.80 & 0.80 & 0.80 & 0.80 & 0.80 & 0.80 & 0.80 & 0.15 & 0.00 & 0.00 & 0.00 & 0.00 & 0.00 \\
\hline $\begin{array}{l}\text { Summer } \\
\text { weekdays }\end{array}$ & 0.00 & 0.00 & 0.00 & 0.00 & 0.40 & 0.40 & 0.40 & 0.40 & 0.40 & 0.00 & 0.00 & 0.00 & 0.00 & 0.00 & 0.00 & 0.00 & 0.00 & 0.00 & 0.00 \\
\hline $\begin{array}{l}\text { Other } \\
\text { days }\end{array}$ & 0.00 & 0.00 & 0.00 & 0.00 & 0.00 & 0.00 & 0.00 & 0.00 & 0.00 & 0.00 & 0.00 & 0.00 & 0.00 & 0.00 & 0.00 & 0.00 & 0.00 & 0.00 & 0.00 \\
\hline
\end{tabular}


Table 48. Secondary School Auditorium Occupancy Schedule

\begin{tabular}{|c|c|c|c|c|c|c|c|c|c|c|c|c|c|c|c|c|c|c|c|}
\hline \multirow{2}{*}{ Schedule } & \multicolumn{19}{|c|}{ Hour } \\
\hline & $1-5$ & 6 & 7 & 8 & 9 & 10 & 11 & 12 & 13 & 14 & 15 & 16 & 18 & 19 & 20 & 21 & 22 & 23 & 24 \\
\hline $\begin{array}{l}\text { School } \\
\text { weekdays }\end{array}$ & 0.00 & 0.00 & 0.00 & 0.00 & 0.00 & 0.00 & 0.00 & 0.00 & 0.00 & 0.00 & 0.10 & 0.10 & 0.10 & 0.10 & 0.10 & 0.10 & 0.10 & 0.00 & 0.00 \\
\hline $\begin{array}{l}\text { Summer } \\
\text { weekdays }\end{array}$ & 0.00 & 0.00 & 0.00 & 0.00 & 0.00 & 0.10 & 0.10 & 0.10 & 0.10 & 0.10 & 0.10 & 0.00 & 0.00 & 0.00 & 0.00 & 0.00 & 0.00 & 0.00 & 0.00 \\
\hline $\begin{array}{l}\text { Other } \\
\text { days }\end{array}$ & 0.00 & 0.00 & 0.00 & 0.00 & 0.00 & 0.00 & 0.00 & 0.00 & 0.00 & 0.00 & 0.00 & 0.00 & 0.00 & 0.00 & 0.00 & 0.00 & 0.00 & 0.00 & 0.00 \\
\hline
\end{tabular}

Table 49. Secondary School Auxiliary Gym Occupancy Schedule

\begin{tabular}{|c|c|c|c|c|c|c|c|c|c|c|c|c|c|c|c|c|c|c|c|}
\hline \multirow{2}{*}{ Schedule } & \multicolumn{19}{|c|}{ Hour } \\
\hline & $1-5$ & 6 & 7 & 8 & 9 & 10 & 11 & 12 & 13 & 14 & 15 & 16 & 18 & 19 & 20 & 21 & 22 & 23 & 24 \\
\hline $\begin{array}{l}\text { School } \\
\text { weekdays }\end{array}$ & 0.00 & 0.00 & 0.00 & 0.00 & 0.00 & 0.02 & 0.02 & 0.02 & 0.02 & 0.02 & 0.06 & 0.06 & 0.06 & 0.06 & 0.06 & 0.06 & 0.06 & 0.00 & 0.00 \\
\hline $\begin{array}{l}\text { Summer } \\
\text { weekdays }\end{array}$ & 0.00 & 0.00 & 0.00 & 0.00 & 0.00 & 0.06 & 0.06 & 0.06 & 0.06 & 0.06 & 0.06 & 0.00 & 0.00 & 0.00 & 0.00 & 0.00 & 0.00 & 0.00 & 0.00 \\
\hline $\begin{array}{l}\text { Other } \\
\text { days }\end{array}$ & 0.00 & 0.00 & 0.00 & 0.00 & 0.00 & 0.00 & 0.00 & 0.00 & 0.00 & 0.00 & 0.00 & 0.00 & 0.00 & 0.00 & 0.00 & 0.00 & 0.00 & 0.00 & 0.00 \\
\hline
\end{tabular}

Table 50. Primary School Infiltration Schedule

\begin{tabular}{|c|c|c|c|c|c|c|c|c|c|c|c|c|c|c|c|c|c|c|c|}
\hline \multirow{2}{*}{ Schedule } & \multicolumn{19}{|c|}{ Hour } \\
\hline & $1-5$ & 6 & 7 & 8 & 9 & 10 & 11 & 12 & 13 & 14 & 15 & 16 & 18 & 19 & 20 & 21 & 22 & 23 & 24 \\
\hline Gym weekdays & 1.00 & 1.00 & 0.50 & 0.50 & 0.50 & 0.50 & 0.50 & 0.50 & 0.50 & 0.50 & 0.50 & 0.50 & 0.50 & 0.50 & 0.50 & 0.50 & 0.50 & 1.00 & 1.00 \\
\hline $\begin{array}{l}\text { Other spaces } \\
\text { Weekdays }\end{array}$ & 1.00 & 1.00 & 0.50 & 0.50 & 0.50 & 0.50 & 0.50 & 0.50 & 0.50 & 0.50 & 0.50 & 0.50 & 0.50 & 0.50 & 1.00 & 1.00 & 1.00 & 1.00 & 1.00 \\
\hline $\begin{array}{l}\text { All spaces } \\
\text { Summer } \\
\text { weekdays }\end{array}$ & 1.00 & 1.00 & 1.00 & 1.00 & 0.50 & 0.50 & 0.50 & 0.50 & 0.50 & 1.00 & 1.00 & 1.00 & 1.00 & 1.00 & 1.00 & 1.00 & 1.00 & 1.00 & 1.00 \\
\hline $\begin{array}{l}\text { All spaces all } \\
\text { other days }\end{array}$ & 1.00 & 1.00 & 1.00 & 1.00 & 1.00 & 1.00 & 1.00 & 1.00 & 1.00 & 1.00 & 1.00 & 1.00 & 1.00 & 1.00 & 1.00 & 1.00 & 1.00 & 1.00 & 1.00 \\
\hline
\end{tabular}

99

This report is available at no cost from the National Renewable Energy Laboratory at www.nrel.gov/publications. 
Table 51. Secondary School Infiltration Schedule

\begin{tabular}{|c|c|c|c|c|c|c|c|c|c|c|c|c|c|c|c|c|c|c|c|}
\hline \multirow{2}{*}{ Schedule } & \multicolumn{19}{|c|}{ Hour } \\
\hline & $1-5$ & 6 & 7 & 8 & 9 & 10 & 11 & 12 & 13 & 14 & 15 & 16 & 18 & 19 & 20 & 21 & 22 & 23 & 24 \\
\hline $\begin{array}{l}\text { Gym/auditorium } \\
\text { weekdays }\end{array}$ & 1.00 & 1.00 & 0.50 & 0.50 & 0.50 & 0.50 & 0.50 & 0.50 & 0.50 & 0.50 & 0.50 & 0.50 & 0.50 & 0.50 & 0.50 & 0.50 & 0.50 & 1.00 & 1.00 \\
\hline $\begin{array}{l}\text { Gym/auditorium } \\
\text { summer } \\
\text { weekdays }\end{array}$ & 1.00 & 1.00 & 1.00 & 1.00 & 0.50 & 0.50 & 0.50 & 0.50 & 0.50 & 0.50 & 0.50 & 1.00 & 1.00 & 1.00 & 1.00 & 1.00 & 1.00 & 1.00 & 1.00 \\
\hline $\begin{array}{l}\text { Other spaces } \\
\text { weekdays }\end{array}$ & 1.00 & 1.00 & 0.50 & 0.50 & 0.50 & 0.50 & 0.50 & 0.50 & 0.50 & 0.50 & 0.50 & 0.50 & 0.50 & 0.50 & 1.00 & 1.00 & 1.00 & 1.00 & 1.00 \\
\hline Other spaces & & & & & & & & & & & & & & & & & & & \\
\hline $\begin{array}{l}\text { summer } \\
\text { weekdays }\end{array}$ & 1.00 & 1.00 & 1.00 & 1.00 & 0.50 & 0.50 & 0.50 & 0.50 & 0.50 & 1.00 & 1.00 & 1.00 & 1.00 & 1.00 & 1.00 & 1.00 & 1.00 & 1.00 & 1.00 \\
\hline $\begin{array}{l}\text { All spaces all } \\
\text { other days }\end{array}$ & 1.00 & 1.00 & 1.00 & 1.00 & 1.00 & 1.00 & 1.00 & 1.00 & 1.00 & 1.00 & 1.00 & 1.00 & 1.00 & 1.00 & 1.00 & 1.00 & 1.00 & 1.00 & 1.00 \\
\hline
\end{tabular}

\section{Table 52. Heating Set Point Schedule}

\begin{tabular}{|c|c|c|c|c|c|c|c|c|c|c|c|c|c|c|c|c|c|c|c|}
\hline \multirow{2}{*}{ Schedule } & \multicolumn{19}{|c|}{ Hour } \\
\hline & $1-5$ & 6 & 7 & 8 & 9 & 10 & 11 & 12 & 13 & 14 & 15 & 16 & 18 & 19 & 20 & 21 & 22 & 23 & 24 \\
\hline $\begin{array}{l}\text { Gym/auditorium } \\
\text { weekdays }\end{array}$ & 60.0 & 60.0 & 71.0 & 71.0 & 71.0 & 71.0 & 71.0 & 71.0 & 71.0 & 71.0 & 71.0 & 71.0 & 71.0 & 71.0 & 71.0 & 71.0 & 71.0 & 60.0 & 60.0 \\
\hline $\begin{array}{l}\text { Secondary } \\
\text { school gym/ } \\
\text { auditorium } \\
\text { summer } \\
\text { weekdays }\end{array}$ & 60.0 & 60.0 & 60.0 & 60.0 & 71.0 & 71.0 & 71.0 & 71.0 & 71.0 & 71.0 & 71.0 & 60.0 & 60.0 & 60.0 & 60.0 & 60.0 & 60.0 & 60.0 & 60.0 \\
\hline $\begin{array}{l}\text { School } \\
\text { weekdays }\end{array}$ & 60.0 & 60.0 & 71.0 & 71.0 & 71.0 & 71.0 & 71.0 & 71.0 & 71.0 & 71.0 & 71.0 & 71.0 & 71.0 & 71.0 & 60.0 & 60.0 & 60.0 & 60.0 & 60.0 \\
\hline $\begin{array}{l}\text { Summer } \\
\text { weekdays }\end{array}$ & 60.0 & 60.0 & 60.0 & 60.0 & 71.0 & 71.0 & 71.0 & 71.0 & 71.0 & 60.0 & 60.0 & 60.0 & 60.0 & 60.0 & 60.0 & 60.0 & 60.0 & 60.0 & 60.0 \\
\hline Other days & 60.0 & 60.0 & 60.0 & 60.0 & 60.0 & 60.0 & 60.0 & 60.0 & 60.0 & 60.0 & 60.0 & 60.0 & 60.0 & 60.0 & 60.0 & 60.0 & 60.0 & 60.0 & 60.0 \\
\hline
\end{tabular}




\section{Table 53. Cooling Set Point Schedule}

\begin{tabular}{|c|c|c|c|c|c|c|c|c|c|c|c|c|c|c|c|c|c|c|c|}
\hline \multirow{2}{*}{ Schedule } & \multicolumn{19}{|c|}{ Hour } \\
\hline & $1-5$ & 6 & 7 & 8 & 9 & 10 & 11 & 12 & 13 & 14 & 15 & 16 & 18 & 19 & 20 & 21 & 22 & 23 & 24 \\
\hline $\begin{array}{l}\text { Gym/auditorium } \\
\text { weekdays }\end{array}$ & 81.0 & 81.0 & 74.0 & 74.0 & 74.0 & 74.0 & 74.0 & 74.0 & 74.0 & 74.0 & 74.0 & 74.0 & 74.0 & 74.0 & 74.0 & 74.0 & 74.0 & 81.0 & 81.0 \\
\hline $\begin{array}{l}\text { Secondary } \\
\text { school gym/ } \\
\text { auditorium } \\
\text { summer } \\
\text { weekdays }\end{array}$ & 81.0 & 81.0 & 81.0 & 81.0 & 74.0 & 74.0 & 74.0 & 74.0 & 74.0 & 74.0 & 74.0 & 81.0 & 81.0 & 81.0 & 81.0 & 81.0 & 81.0 & 81.0 & 81.0 \\
\hline $\begin{array}{l}\text { School } \\
\text { weekdays }\end{array}$ & 81.0 & 81.0 & 74.0 & 74.0 & 74.0 & 74.0 & 74.0 & 74.0 & 74.0 & 74.0 & 74.0 & 74.0 & 74.0 & 74.0 & 81.0 & 81.0 & 81.0 & 81.0 & 81.0 \\
\hline $\begin{array}{l}\text { Summer } \\
\text { weekdays }\end{array}$ & 81.0 & 81.0 & 81.0 & 81.0 & 74.0 & 74.0 & 74.0 & 74.0 & 74.0 & 81.0 & 81.0 & 81.0 & 81.0 & 81.0 & 81.0 & 81.0 & 81.0 & 81.0 & 81.0 \\
\hline Other days & 81.0 & 81.0 & 81.0 & 81.0 & 81.0 & 81.0 & 81.0 & 81.0 & 81.0 & 81.0 & 81.0 & 81.0 & 81.0 & 81.0 & 81.0 & 81.0 & 81.0 & 81.0 & 81.0 \\
\hline
\end{tabular}

Table 54. Secondary School Elevator Schedule

\begin{tabular}{lllllllllllllllllllll}
\hline Schedule & $\begin{array}{c}\text { Hour } \\
\mathbf{1 - 5}\end{array}$ & $\mathbf{6}$ & $\mathbf{7}$ & $\mathbf{8}$ & $\mathbf{9}$ & $\mathbf{1 0}$ & $\mathbf{1 1}$ & $\mathbf{1 2}$ & $\mathbf{1 3}$ & $\mathbf{1 4}$ & $\mathbf{1 5}$ & $\mathbf{1 6}$ & $\mathbf{1 8}$ & $\mathbf{1 9}$ & $\mathbf{2 0}$ & $\mathbf{2 1}$ & $\mathbf{2 2}$ & $\mathbf{2 3}$ & $\mathbf{2 4}$ \\
\hline $\begin{array}{l}\text { School } \\
\text { weekdays }\end{array}$ & 0.00 & 0.00 & 0.00 & 0.00 & 0.30 & 0.30 & 0.30 & 0.30 & 0.30 & 0.30 & 0.30 & 0.15 & 0.00 & 0.00 & 0.00 & 0.00 & 0.00 & 0.00 & 0.00 \\
$\begin{array}{l}\text { Summer } \\
\text { weekdays }\end{array}$ & 0.00 & 0.00 & 0.00 & 0.00 & 0.00 & 0.00 & 0.00 & 0.00 & 0.00 & 0.00 & 0.00 & 0.00 & 0.00 & 0.00 & 0.00 & 0.00 & 0.00 & 0.00 & 0.00 \\
$\begin{array}{l}\text { Other } \\
\text { days }\end{array}$ & 0.00 & 0.00 & 0.00 & 0.00 & 0.00 & 0.00 & 0.00 & 0.00 & 0.00 & 0.00 & 0.00 & 0.00 & 0.00 & 0.00 & 0.00 & 0.00 & 0.00 & 0.00 & 0.00 \\
\hline
\end{tabular}


Table 55. Prototype Lighting Schedule

\begin{tabular}{|c|c|c|c|c|c|c|c|c|c|c|c|c|c|c|c|c|c|c|c|}
\hline \multirow{2}{*}{ Schedule } & \multicolumn{19}{|c|}{ Hour } \\
\hline & $1-5$ & 6 & 7 & 8 & 9 & 10 & 11 & 12 & 13 & 14 & 15 & 16 & 18 & 19 & 20 & 21 & 22 & 23 & 24 \\
\hline $\begin{array}{l}\text { School } \\
\text { weekdays }\end{array}$ & 0.20 & 0.20 & 0.40 & 0.90 & 0.90 & 0.90 & 0.90 & 0.90 & 0.90 & 0.90 & 0.90 & 0.90 & 0.70 & 0.70 & 0.70 & 0.50 & 0.50 & 0.20 & 0.20 \\
\hline $\begin{array}{l}\text { Summer } \\
\text { weekdays }\end{array}$ & 0.20 & 0.20 & 0.20 & 0.20 & 0.50 & 0.50 & 0.50 & 0.50 & 0.50 & 0.50 & 0.20 & 0.20 & 0.20 & 0.20 & 0.20 & 0.20 & 0.20 & 0.20 & 0.20 \\
\hline $\begin{array}{l}\text { Other } \\
\text { days }\end{array}$ & 0.20 & 0.20 & 0.20 & 0.20 & 0.20 & 0.20 & 0.20 & 0.20 & 0.20 & 0.20 & 0.20 & 0.20 & 0.20 & 0.20 & 0.20 & 0.20 & 0.20 & 0.20 & 0.20 \\
\hline
\end{tabular}

Table 56. Primary School Prototype Electric Equipment Schedule

\begin{tabular}{|c|c|c|c|c|c|c|c|c|c|c|c|c|c|c|c|c|c|c|c|}
\hline \multirow{2}{*}{ Schedule } & \multicolumn{19}{|c|}{ Hour } \\
\hline & $1-5$ & 6 & 7 & 8 & 9 & 10 & 11 & 12 & 13 & 14 & 15 & 16 & 18 & 19 & 20 & 21 & 22 & 23 & 24 \\
\hline $\begin{array}{l}\text { School } \\
\text { weekdays }\end{array}$ & 0.40 & 0.40 & 0.40 & 0.40 & 0.60 & 0.60 & 0.60 & 0.60 & 0.60 & 0.60 & 0.60 & 0.40 & 0.40 & 0.40 & 0.40 & 0.40 & 0.40 & 0.40 & 0.40 \\
\hline $\begin{array}{l}\text { Summer } \\
\text { weekdays }\end{array}$ & 0.40 & 0.40 & 0.40 & 0.40 & 0.40 & 0.60 & 0.60 & 0.60 & 0.60 & 0.40 & 0.40 & 0.40 & 0.40 & 0.40 & 0.40 & 0.40 & 0.40 & 0.40 & 0.40 \\
\hline $\begin{array}{l}\text { Other } \\
\text { days }\end{array}$ & 0.40 & 0.40 & 0.40 & 0.40 & 0.40 & 0.40 & 0.40 & 0.40 & 0.40 & 0.40 & 0.40 & 0.40 & 0.40 & 0.40 & 0.40 & 0.40 & 0.40 & 0.40 & 0.40 \\
\hline
\end{tabular}

Table 57. Primary School Prototype Kitchen Electric Equipment Schedule

\begin{tabular}{|c|c|c|c|c|c|c|c|c|c|c|c|c|c|c|c|c|c|c|c|}
\hline \multirow{2}{*}{ Schedule } & \multicolumn{19}{|l|}{ Hour } \\
\hline & $1-5$ & 6 & 7 & 8 & 9 & 10 & 11 & 12 & 13 & 14 & 15 & 16 & 18 & 19 & 20 & 21 & 22 & 23 & 24 \\
\hline $\begin{array}{l}\text { School } \\
\text { weekdays }\end{array}$ & 0.27 & 0.33 & 0.47 & 0.84 & 0.75 & 0.50 & 0.72 & 0.91 & 1.00 & 0.41 & 0.34 & 0.27 & 0.27 & 0.27 & 0.27 & 0.27 & 0.27 & 0.27 & 0.27 \\
\hline $\begin{array}{l}\text { Summer } \\
\text { weekdays }\end{array}$ & 0.27 & 0.27 & 0.27 & 0.27 & 0.27 & 0.27 & 0.27 & 0.27 & 0.27 & 0.27 & 0.27 & 0.27 & 0.27 & 0.27 & 0.27 & 0.27 & 0.27 & 0.27 & 0.27 \\
\hline $\begin{array}{l}\text { Other } \\
\text { days }\end{array}$ & 0.27 & 0.27 & 0.27 & 0.27 & 0.27 & 0.27 & 0.27 & 0.27 & 0.27 & 0.27 & 0.27 & 0.27 & 0.27 & 0.27 & 0.27 & 0.27 & 0.27 & 0.27 & 0.27 \\
\hline
\end{tabular}


Table 58. Primary School Prototype Kitchen Gas Equipment Schedule

\begin{tabular}{|c|c|c|c|c|c|c|c|c|c|c|c|c|c|c|c|c|c|c|c|}
\hline \multirow{2}{*}{ Schedule } & \multicolumn{19}{|l|}{ Hour } \\
\hline & $1-5$ & 6 & 7 & 8 & 9 & 10 & 11 & 12 & 13 & 14 & 15 & 16 & 18 & 19 & 20 & 21 & 22 & 23 & 24 \\
\hline $\begin{array}{l}\text { School } \\
\text { weekdays }\end{array}$ & 0.03 & 0.03 & 1.00 & 1.00 & 0.33 & 0.07 & 1.00 & 1.00 & 1.00 & 0.03 & 0.03 & 0.03 & 0.03 & 0.03 & 0.03 & 0.03 & 0.03 & 0.03 & 0.03 \\
\hline $\begin{array}{l}\text { Summer } \\
\text { weekdays }\end{array}$ & 0.03 & 0.03 & 0.03 & 0.03 & 0.03 & 0.03 & 0.03 & 0.03 & 0.03 & 0.03 & 0.03 & 0.03 & 0.03 & 0.03 & 0.03 & 0.03 & 0.03 & 0.03 & 0.03 \\
\hline $\begin{array}{l}\text { Other } \\
\text { days }\end{array}$ & 0.03 & 0.03 & 0.03 & 0.03 & 03 & 0.03 & 0.03 & .03 & 0.03 & 0.03 & 0.03 & 0.03 & 0.03 & 0.03 & 0.03 & .03 & 0.03 & 0.03 & 0.03 \\
\hline
\end{tabular}

Table 59. Secondary School Prototype Electric Equipment Schedule

\begin{tabular}{|c|c|c|c|c|c|c|c|c|c|c|c|c|c|c|c|c|c|c|c|}
\hline \multirow{2}{*}{ Schedule } & \multicolumn{19}{|c|}{ Hour } \\
\hline & $1-5$ & 6 & 7 & 8 & 9 & 10 & 11 & 12 & 13 & 14 & 15 & 16 & 18 & 19 & 20 & 21 & 22 & 23 & 24 \\
\hline $\begin{array}{l}\text { School } \\
\text { weekdays }\end{array}$ & 0.50 & 0.50 & 0.50 & 0.50 & 0.65 & 0.65 & 0.65 & 0.65 & 0.65 & 0.65 & 0.65 & 0.50 & 0.50 & 0.50 & 0.50 & 0.50 & 0.50 & 0.50 & 0.50 \\
\hline $\begin{array}{l}\text { Summer } \\
\text { weekdays }\end{array}$ & 0.50 & 0.50 & 0.50 & 0.50 & 0.65 & 0.65 & 0.65 & 0.65 & 0.65 & 0.50 & 0.50 & 0.50 & 0.50 & 0.50 & 0.50 & 0.50 & 0.50 & 0.50 & 0.50 \\
\hline $\begin{array}{l}\text { Other } \\
\text { days }\end{array}$ & 0.50 & 0.50 & 0.50 & 0.50 & .50 & 0.50 & 0.50 & 0.50 & 0.50 & 0.50 & 0.50 & 0.50 & .50 & 0.50 & 0.50 & .50 & 0.50 & 0.50 & 0.50 \\
\hline
\end{tabular}

Table 60. Secondary School Prototype Kitchen Electric Equipment Schedule

\begin{tabular}{|c|c|c|c|c|c|c|c|c|c|c|c|c|c|c|c|c|c|c|c|}
\hline \multirow{2}{*}{ Schedule } & \multicolumn{19}{|c|}{ Hour } \\
\hline & $1-5$ & 6 & 7 & 8 & 9 & 10 & 11 & 12 & 13 & 14 & 15 & 16 & 18 & 19 & 20 & 21 & 22 & 23 & 24 \\
\hline $\begin{array}{l}\text { School } \\
\text { weekdays }\end{array}$ & 0.40 & 0.40 & 0.87 & 1.00 & 0.78 & 0.78 & 0.78 & 1.00 & 1.00 & 0.61 & 0.47 & 0.40 & 0.40 & 0.40 & 0.40 & 0.40 & 0.40 & 0.40 & 0.40 \\
\hline $\begin{array}{l}\text { Summer } \\
\text { weekdays }\end{array}$ & 0.40 & 0.40 & 0.40 & 0.40 & 0.40 & 0.40 & 0.40 & 0.40 & 0.40 & 0.40 & 0.40 & 0.40 & 0.40 & 0.40 & 0.40 & 0.40 & 0.40 & 0.40 & 0.40 \\
\hline $\begin{array}{l}\text { Other } \\
\text { days }\end{array}$ & 0.40 & 0.40 & 0.40 & 0.40 & 0.40 & 0.40 & 0.40 & 0.40 & 0.40 & 0.40 & 0.40 & 0.40 & 0.40 & 0.40 & 0.40 & 0.40 & 0.40 & 0.40 & 0.40 \\
\hline
\end{tabular}


Table 61. Secondary School Prototype Kitchen Gas Equipment Schedule

\begin{tabular}{|c|c|c|c|c|c|c|c|c|c|c|c|c|c|c|c|c|c|c|c|}
\hline \multirow{2}{*}{ Schedule } & \multicolumn{19}{|c|}{ Hour } \\
\hline & $1-5$ & 6 & 7 & 8 & 9 & 10 & 11 & 12 & 13 & 14 & 15 & 16 & 18 & 19 & 20 & 21 & 22 & 23 & 24 \\
\hline $\begin{array}{l}\text { School } \\
\text { weekdays }\end{array}$ & 0.18 & 0.18 & 0.92 & 0.76 & 0.38 & 0.38 & 0.85 & 1.00 & 1.00 & 0.02 & 0.02 & 0.02 & 0.02 & 0.02 & 0.02 & 0.02 & 0.02 & 0.02 & 0.02 \\
\hline $\begin{array}{l}\text { Summer } \\
\text { weekdays }\end{array}$ & 0.02 & 0.02 & 0.02 & 0.02 & 0.02 & 0.02 & 0.02 & 0.02 & 0.02 & 0.02 & 0.02 & 0.02 & 0.02 & 0.02 & 0.02 & 0.02 & 0.02 & 0.02 & 0.02 \\
\hline $\begin{array}{l}\text { Other } \\
\text { days }\end{array}$ & 0.02 & 0.02 & 0.02 & 0.02 & 0.02 & 0.02 & 0.02 & 0.02 & 0.02 & 0.02 & 0.02 & 0.02 & 0.02 & 0.02 & 0.02 & 0.02 & 0.02 & 0.02 & 0.02 \\
\hline
\end{tabular}

Table 62. General SWH Schedule

\begin{tabular}{|c|c|c|c|c|c|c|c|c|c|c|c|c|c|c|c|c|c|c|c|}
\hline \multirow{2}{*}{ Schedule } & \multicolumn{19}{|l|}{ Hour } \\
\hline & $1-5$ & 6 & 7 & 8 & 9 & 10 & 11 & 12 & 13 & 14 & 15 & 16 & 18 & 19 & 20 & 21 & 22 & 23 & 24 \\
\hline $\begin{array}{l}\text { School } \\
\text { weekdays }\end{array}$ & 0.05 & 0.05 & 05 & 0.10 & 0.34 & 0.60 & 63 & 0.72 & 0.79 & 83 & 61 & 0.65 & 0.10 & 10 & 19 & 0.25 & 22 & .22 & 0.12 \\
\hline $\begin{array}{l}\text { Summer } \\
\text { weekdays }\end{array}$ & 0.05 & 0.05 & 0.05 & 0.10 & 0.10 & 0.10 & 0.10 & 0.10 & 0.10 & 0.10 & 0.10 & 0.10 & 0.10 & 0.10 & 0.19 & 0.25 & 0.22 & 0.22 & 0.12 \\
\hline $\begin{array}{l}\text { Other } \\
\text { days }\end{array}$ & 0.03 & 0.03 & .03 & 0.03 & 0.05 & .05 & .05 & 0.05 & 0.05 & 0.05 & 0.03 & 0.03 & 0.03 & .03 & 0.03 & 0.03 & 0.03 & 0.03 & 0.03 \\
\hline
\end{tabular}

Table 63. Secondary School Shower SWH Schedule

\begin{tabular}{|c|c|c|c|c|c|c|c|c|c|c|c|c|c|c|c|c|c|c|c|}
\hline \multirow{2}{*}{ Schedule } & \multicolumn{19}{|c|}{ Hour } \\
\hline & $1-5$ & 6 & 7 & 8 & 9 & 10 & 11 & 12 & 13 & 14 & 15 & 16 & 18 & 19 & 20 & 21 & 22 & 23 & 24 \\
\hline $\begin{array}{l}\text { School } \\
\text { weekdays }\end{array}$ & 0.00 & 0.00 & 0.00 & 0.60 & 0.50 & 0.50 & 0.50 & 0.50 & 0.50 & 0.50 & 0.50 & 0.50 & 1.00 & 1.00 & 1.00 & 0.00 & 0.00 & 0.00 & 0.00 \\
\hline $\begin{array}{l}\text { Summer } \\
\text { weekdays }\end{array}$ & 0.00 & 0.00 & 0.00 & 0.00 & 0.30 & 0.10 & 0.10 & 0.10 & 0.10 & 0.10 & 0.10 & 0.10 & 0.00 & 0.00 & 0.00 & 0.00 & 0.00 & 0.00 & 0.00 \\
\hline $\begin{array}{l}\text { Other } \\
\text { days }\end{array}$ & 0.00 & 0.00 & 0.00 & 0.00 & 0.00 & 0.00 & 0.00 & 0.00 & 0.00 & 0.00 & 0.00 & 0.00 & 0.00 & 0.00 & 0.00 & 0.00 & 0.00 & 0.00 & 0.00 \\
\hline
\end{tabular}


Table 64. Primary School Zero Energy Electric Equipment Schedule

\begin{tabular}{|c|c|c|c|c|c|c|c|c|c|c|c|c|c|c|c|c|c|c|c|}
\hline \multirow{2}{*}{ Schedule } & \multicolumn{19}{|c|}{ Hour } \\
\hline & $1-5$ & 6 & 7 & 8 & 9 & 10 & 11 & 12 & 13 & 14 & 15 & 16 & 18 & 19 & 20 & 21 & 22 & 23 & 24 \\
\hline $\begin{array}{l}\text { School } \\
\text { weekdays }\end{array}$ & 0.15 & 0.15 & 0.15 & 0.15 & 0.60 & 0.60 & 0.60 & 0.60 & 0.60 & 0.60 & 0.60 & 0.15 & 0.15 & 0.15 & 0.15 & 0.15 & 0.15 & 0.15 & 0.15 \\
\hline $\begin{array}{l}\text { Summer } \\
\text { weekdays }\end{array}$ & 0.15 & 0.15 & 0.15 & 0.15 & 0.15 & 0.60 & 0.60 & 0.60 & 0.60 & 0.15 & 0.15 & 0.15 & 0.15 & 0.15 & 0.15 & 0.15 & 0.15 & 0.15 & 0.15 \\
\hline $\begin{array}{l}\text { Other } \\
\text { days }\end{array}$ & 0.15 & 0.15 & 0.15 & 0.15 & 0.15 & 0.15 & 0.15 & 0.15 & 0.15 & 0.15 & 0.15 & 0.15 & 0.15 & 0.15 & 0.15 & 0.15 & 0.15 & 0.15 & 0.15 \\
\hline
\end{tabular}

Table 65. Primary School Zero Energy Kitchen Electric Equipment Schedule

\begin{tabular}{|c|c|c|c|c|c|c|c|c|c|c|c|c|c|c|c|c|c|c|c|}
\hline \multirow{2}{*}{ Schedule } & \multicolumn{19}{|c|}{ Hour } \\
\hline & $1-5$ & 6 & 7 & 8 & 9 & 10 & 11 & 12 & 13 & 14 & 15 & 16 & 18 & 19 & 20 & 21 & 22 & 23 & 24 \\
\hline $\begin{array}{l}\text { School } \\
\text { weekdays }\end{array}$ & 0.29 & 0.35 & 0.45 & 0.85 & 0.78 & 0.55 & 0.70 & 0.89 & 1.00 & 0.45 & 0.36 & 0.29 & 0.29 & 0.29 & 0.29 & 0.29 & 0.29 & 0.29 & 0.29 \\
\hline $\begin{array}{l}\text { Summer } \\
\text { weekdays }\end{array}$ & 0.29 & 0.29 & 0.29 & 0.29 & 0.29 & 0.29 & 0.29 & 0.29 & 0.29 & 0.29 & 0.29 & 0.29 & 0.29 & 0.29 & 0.29 & 0.29 & 0.29 & 0.29 & 0.29 \\
\hline $\begin{array}{l}\text { Other } \\
\text { days }\end{array}$ & 0.29 & 0.29 & 0.29 & 0.29 & 0.29 & 0.29 & 0.29 & 0.29 & 0.29 & 0.29 & 0.29 & 0.29 & 0.29 & 0.29 & 0.29 & 0.29 & 0.29 & 0.29 & 0.29 \\
\hline
\end{tabular}

Table 66. Primary School Zero Energy Kitchen Gas Equipment Schedule

\begin{tabular}{|c|c|c|c|c|c|c|c|c|c|c|c|c|c|c|c|c|c|c|c|}
\hline \multirow{2}{*}{ Schedule } & \multicolumn{19}{|c|}{ Hour } \\
\hline & $1-5$ & 6 & 7 & 8 & 9 & 10 & 11 & 12 & 13 & 14 & 15 & 16 & 18 & 19 & 20 & 21 & 22 & 23 & 24 \\
\hline $\begin{array}{l}\text { School } \\
\text { weekdays }\end{array}$ & 0.04 & 0.04 & 1.00 & 1.00 & 0.32 & 0.06 & 1.00 & 1.00 & 1.00 & 0.04 & 0.04 & 0.04 & 0.04 & 0.04 & 0.04 & 0.04 & 0.04 & 0.04 & 0.04 \\
\hline $\begin{array}{l}\text { Summer } \\
\text { weekdays }\end{array}$ & 0.04 & 0.04 & 0.04 & 0.04 & 0.04 & 0.04 & 0.04 & 0.04 & 0.04 & 0.04 & 0.04 & 0.04 & 0.04 & 0.04 & 0.04 & 0.04 & 0.04 & 0.04 & 0.04 \\
\hline $\begin{array}{l}\text { Other } \\
\text { days }\end{array}$ & 0.04 & 0.04 & 0.04 & 0.04 & 0.04 & 0.04 & 0.04 & 0.04 & 0.04 & 0.04 & 0.04 & 0.04 & 0.04 & 0.04 & 0.04 & 0.04 & 0.04 & 0.04 & 0.04 \\
\hline
\end{tabular}


Table 67. Secondary School Zero Energy Electric Equipment Schedule

\begin{tabular}{|c|c|c|c|c|c|c|c|c|c|c|c|c|c|c|c|c|c|c|c|}
\hline \multirow{2}{*}{ Schedule } & \multicolumn{19}{|l|}{ Hour } \\
\hline & $1-5$ & 6 & 7 & 8 & 9 & 10 & 11 & 12 & 13 & 14 & 15 & 16 & 18 & 19 & 20 & 21 & 22 & 23 & 24 \\
\hline $\begin{array}{l}\text { School } \\
\text { weekdays }\end{array}$ & 0.25 & 0.25 & 0.25 & 0.25 & 0.65 & 0.65 & 0.65 & 0.65 & 0.65 & 0.65 & 0.65 & 0.25 & 0.25 & 0.25 & 0.25 & 0.25 & 0.25 & 0.25 & 0.25 \\
\hline $\begin{array}{l}\text { Summer } \\
\text { weekdays }\end{array}$ & 0.25 & 0.25 & 0.25 & 0.25 & 0.65 & 0.65 & 0.65 & 0.65 & 0.65 & 0.25 & 0.25 & 0.25 & 0.25 & 0.25 & 0.25 & 0.25 & 0.25 & 0.25 & 0.25 \\
\hline $\begin{array}{l}\text { Other } \\
\text { days }\end{array}$ & 0.25 & 0.25 & 0.25 & 0.25 & 0.25 & 0.25 & 0.25 & 0.25 & 0.25 & 0.25 & 0.25 & 0.25 & 0.25 & 0.25 & 0.25 & 0.25 & 0.25 & 0.25 & 0.25 \\
\hline
\end{tabular}

Table 68. Secondary School Zero Energy Kitchen Electric Equipment Schedule

\begin{tabular}{|c|c|c|c|c|c|c|c|c|c|c|c|c|c|c|c|c|c|c|c|}
\hline \multirow{2}{*}{ Schedule } & \multicolumn{19}{|c|}{ Hour } \\
\hline & $1-5$ & 6 & 7 & 8 & 9 & 10 & 11 & 12 & 13 & 14 & 15 & 16 & 18 & 19 & 20 & 21 & 22 & 23 & 24 \\
\hline $\begin{array}{l}\text { School } \\
\text { weekdays }\end{array}$ & 0.38 & 0.38 & 0.86 & 1.00 & 0.77 & 0.77 & 0.77 & 1.00 & 1.00 & 0.60 & 0.46 & 0.38 & 0.38 & 0.38 & 0.38 & 0.38 & 0.38 & 0.38 & 0.38 \\
\hline $\begin{array}{l}\text { Summer } \\
\text { weekdays }\end{array}$ & 0.38 & 0.38 & 0.38 & 0.38 & 0.38 & 0.38 & 0.38 & 0.38 & 0.38 & 0.38 & 0.38 & 0.38 & 0.38 & 0.38 & 0.38 & 0.38 & 0.38 & 0.38 & 0.38 \\
\hline $\begin{array}{l}\text { Other } \\
\text { days }\end{array}$ & 0.38 & 0.38 & 0.38 & 0.38 & 0.38 & 0.38 & 0.38 & 0.38 & 0.38 & 0.38 & 0.38 & 0.38 & 0.38 & 0.38 & 0.38 & 0.38 & 0.38 & 0.38 & 0.38 \\
\hline
\end{tabular}

Table 69. Secondary School Zero Energy Kitchen Gas Equipment Schedule

\begin{tabular}{|c|c|c|c|c|c|c|c|c|c|c|c|c|c|c|c|c|c|c|c|}
\hline \multirow{2}{*}{ Schedule } & \multicolumn{19}{|c|}{ Hour } \\
\hline & $1-5$ & 6 & 7 & 8 & 9 & 10 & 11 & 12 & 13 & 14 & 15 & 16 & 18 & 19 & 20 & 21 & 22 & 23 & 24 \\
\hline $\begin{array}{l}\text { School } \\
\text { weekdays }\end{array}$ & 0.22 & 0.22 & 0.99 & 0.79 & 0.40 & 0.40 & 0.86 & 1.00 & 1.00 & 0.02 & 0.02 & 0.02 & 0.02 & 0.02 & 0.02 & 0.02 & 0.02 & 0.02 & 0.02 \\
\hline $\begin{array}{l}\text { Summer } \\
\text { weekdays }\end{array}$ & 0.02 & 0.02 & 0.02 & 0.02 & 0.02 & 0.02 & 0.02 & 0.02 & 0.02 & 0.02 & 0.02 & 0.02 & 0.02 & 0.02 & 0.02 & 0.02 & 0.02 & 0.02 & 0.02 \\
\hline $\begin{array}{l}\text { Other } \\
\text { days }\end{array}$ & 0.02 & 0.02 & 0.02 & 0.02 & 0.02 & 0.02 & 0.02 & 0.02 & 0.02 & 0.02 & 0.02 & 0.02 & 0.02 & 0.02 & 0.02 & 0.02 & 0.02 & 0.02 & 0.02 \\
\hline
\end{tabular}




\section{Appendix B. EnergyPlus Refrigeration Objects Primary School}

Refrigeration:Case,

Kitchen WalkInFreezer_Case:1, ! - Name

ALWAYS_ON, !- Availablility Schedule

Kitchen, !- Zone Name

23.88, !- Rated Ambient Temperature (C)

55.0, !- Rated Ambient Relative Humidity (\%)

734, !- Rated Total Cooling Capacity per Unit length $(\mathrm{W} / \mathrm{m})$

0.1, !- Rated Latent Heat Ratio

0.4, ! - Rated Runtime Fraction

3.66, !- Case Length (m)

-23, !- Case Operating Temperature (C)

CaseTemperatureMethod, !- Latent Case Credit Curve Type

Kitchen_WalkInFreezer_Case:1_LatentCaseCreditCurve, !- Latent Case Credit Curve Name

68.3, !- Standard Casēe Fan Pöwer per Unit Length $(\mathrm{W} / \mathrm{m})$

172.2, !- Operating Case Fan Power per Unit Length $(\mathrm{W} / \mathrm{m})$

33, !- Standard Case Lighting Power per Unit Length $(\mathrm{W} / \mathrm{m})$

28.1, !- Installed Case Lighting Power per Unit Length $(\mathrm{W} / \mathrm{m})$

BLDG_LIGHT_SCH, !- Case Lighting Schedule Name

1, !- Fraction of Lighting Energy To Case

0.0, !- Case Anti-Sweat Heater Power per Unit Length $(\mathrm{W} / \mathrm{m})$

0.0, !- Minimum Anti-Sweat Heater Power per Unit Length $(\mathrm{W} / \mathrm{m})$

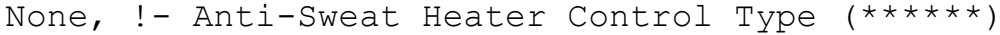

0.0, !- Humidity At Zero Anti-Sweat Heater Energy (\%)

0.0, ! - Case Height (m)

0.0, !- Fraction of Anti-Sweat Heater Energy To Case ()

547, !- Case Defrost Power per Unit Length (W/m)

Electric, !- Case Defrost Type

Kitchen_WalkInFreezer_Case:1_DefrostSchedule, !- Case Defrost Schedule Name

Kitchen WalkInFreezer Case:1-DefrostDripDownSchedule, !- Case Defrost Drip-Down Schedule

None, !- Defrost Energy Correction Curve Type

, !- Defrost Energy Correction Curve Name

0.0, !- Under Case HVAC Return Air Fraction ()

Kitchen_WalkInFreezer_Case:1_RestockSchedule, !- Refrigerated Case Restocking Schedule Name

Kitchen_WalkInFreezer_Case:1_CaseCreditSchedule; !- Case Credit Fraction Schedule Name

Curve: Cubic,

Kitchen_WalkInFreezer_Case:1_LatentCaseCreditCurve, !- Name 
0.0236, !- Coefficient1 Constant

0.0006, !- Coefficient $2 \mathrm{x}$

$0.0000, !-$ Coefficient $3 x^{* * 2}$

$0.0000, !-$ Coefficient $4 x * * 3$

-35.0, ! - Minimum Value of $x$

20.0; !- Maximum Value of $\mathrm{x}$

Schedule:Compact,

Kitchen_WalkInFreezer_Case:1_DefrostSchedule, !- Name

ON/OFF, !- Schedule type

Through: 12/31, !- Complex field \#1

For:AllDays, !- Complex field \#2

Interpolate:Yes, !- Complex field \#3

Until: 11:00, 0, !- Complex field \#4

Until: 11:20, 1, !- Complex field \#5

Until: 23:00, 0, !- Complex field \#6

Until: 23:20, 1, !- Complex field \#7

Until: 24:00, 0; !- Complex field \#8

Schedule:Compact,

Kitchen_WalkInFreezer_Case:1_DefrostDripDownSchedule, !- Name

ON/OFF, !- Schedule tȳpe

Through: 12/31, !- Complex field \#1

For:AllDays, !- Complex field \#2

Interpolate:Yes, !- Complex field \#3

Until: 11:00, 0, !- Complex field \#4

Until: 11:30, 1, !- Complex field \#5

Until: 23:00, 0, !- Complex field \#6

Until: 23:30, 1, !- Complex field \#7

Until: 24:00, 0; !- Complex field \#8

Curve:Cubic,

Kitchen WalkInFreezer Case: 1 DefrostEnergyCorrectionCurve, !- Name

0.0236, ! - Coefficienti Constant

0.0006, !- Coefficient2 $\mathrm{x}$

0.0000, !- Coefficient $3 x^{* * 2}$

0.0000, !- Coefficient $4 x^{* *} 3$

-35.0, !- Minimum Value of $x$

20.0; !- Maximum Value of $\mathrm{x}$

Schedule: Compact,

This report is available at no cost from the National Renewable Energy Laboratory at www.nrel.gov/publications. 
Kitchen WalkInFreezer Case:1 RestockSchedule, !- Name Any Number, !- Schedule type

Through: 12/31, !- Complex field \#1

For: Tuesday Friday, !- Complex field \#2

Until: 4:00, 0.0, !- Complex field \#3

Until: 5:00, 725.0, !- Complex field \#4

Until: 6:00, 417.0, !-Complex field \#5

Until: 7:00, 290.0, !- Complex field \#6

Until: 24:00, 0.0, !- Complex field \#7

For: AllotherDays, !- Complex field \#8

Until: 4:00, 0.0, !- Complex field \#9

Until: 5:00, 125.0, !-Complex field \#10

Until: 6:00, 117.0, !- Complex field \#11

Until: 7:00, 90.0, !- Complex field \#12

Until: 19:00, 0.0, !-Complex field \#13

Until: 20:00, 125.0, !-Complex field \#14

Until: 21:00, 117.0, !-Complex field \#15

Until: 22:00, 90.0, !- Complex field \#16

Until: 24:00, 0.0; !-Complex field \#17

Schedule: Compact,

Kitchen_WalkInFreezer_Case:1_CaseCreditSchedule, !- Name

Fraction, !- Schedule type

Through: 12/31, !- Complex field \#1

For:AllDays, !- Complex field \#2

Interpolate:No, !- Complex field \#3

Until: 7:00, 0.2, !- Complex field \#4

Until: 21:00, 0.4, !-Complex field \#5

Until: 24:00, 0.2; !- Complex field \#6

Refrigeration:Case,

Kitchen_SelfContainedDisplayCase_Case:2, !- Name

ALWAYS ON, !- Availablility Schedule

Kitchen, !- Zone Name

23.88, !- Rated Ambient Temperature (C)

55.0, !- Rated Ambient Relative Humidity (\%)

734, !- Rated Total Cooling Capacity per Unit length $(\mathrm{W} / \mathrm{m})$

0.08, !- Rated Latent Heat Ratio

0.85, !- Rated Runtime Fraction

3.66, !- Case Length (m)

2, !- Case Operating Temperature (C)

This report is available at no cost from the National Renewable Energy Laboratory at www.nrel.gov/publications. 
CaseTemperatureMethod, !- Latent Case Credit Curve Type

Kitchen_SelfContainedDisplayCase_Case:2_LatentCaseCreditCurve, !- Latent Case Credit Curve Name 55, !- Standard Case Fan Power per Unit Length (W/m)

40.0, !- Operating Case Fan Power per Unit Length $(\mathrm{W} / \mathrm{m})$

33, !- Standard Case Lighting Power per Unit Length $(\mathrm{W} / \mathrm{m})$

75.0, !- Installed Case Lighting Power per Unit Length $(\mathrm{W} / \mathrm{m})$

BLDG_LIGHT_SCH, !- Case Lighting Schedule Name

1, !- Fraction of Lighting Energy To Case

0.0$, !- Case Anti-Sweat Heater Power per Unit Length ( $\mathrm{W} / \mathrm{m})$

0.0, !- Minimum Anti-Sweat Heater Power per Unit Length $(\mathrm{W} / \mathrm{m})$

None, !- Anti-Sweat Heater Control Type $(* \star \star \star \star * *)$

0.0, !- Humidity At Zero Anti-Sweat Heater Energy (\%)

0.0, !- Case Height (m)

0.2 , !- Fraction of Anti-Sweat Heater Energy To Case ()

0, !- Case Defrost Power per Unit Length $(\mathrm{W} / \mathrm{m})$

None, !- Case Defrost Type (*******)

, !- Case Defrost Schedule Name

, !- Case Defrost Drip-Down Schedule

None, !- Defrost Energy Correction Curve Type

, !- Defrost Energy Correction Curve Name

0.05, !- Under Case HVAC Return Air Fraction ()

Kitchen_SelfContainedDisplayCase_Case:2_RestockSchedule; !- Refrigerated Case Restocking Schedule Name

Curve:Cubic,

Kitchen SelfContainedDisplayCase Case:2 LatentCaseCreditCurve, !- Name

$0.02652 \overline{6} 281$, !- Coefficient1 Constant

0.001078032, !- Coefficient2 $x$

0.0000602558, !- Coefficient $3 x * * 2$

$0.00000123732, \quad !-$ Coefficient $4 x^{* * 3}$

-35.0, !- Minimum Value of $x$

$20.0 ;$ ! - Maximum Value of $x$

Curve:Cubic,

Kitchen_SelfContainedDisplayCase_Case:2_DefrostEnergyCorrectionCurve, !- Name

0.0236, !- Coefficient1 Constant

0.0006, !- Coefficient2 $\mathrm{x}$

0.0000, !- Coefficient $3 x^{*} * 2$

0.0000, ! - Coefficient $4 x^{*} * 3$

-35.0, !- Minimum Value of $x$

20.0; ! - Maximum Value of $x$

This report is available at no cost from the National Renewable Energy Laboratory at www.nrel.gov/publications. 
Schedule: Compact,

Kitchen_SelfContainedDisplayCase_Case:2_RestockSchedule, !- Name

Any Number, !- Schedule type

Through: 12/31, !- Complex field \#1

For:AllDays, !- Complex field \#2

Until: 6:00, 0.0, !- Complex field \#3

Until: 7:00, 50.0, !-Complex field \#4

Until: 9:00, 70.0, !- Complex field \#5

Until: 10:00, 80.0, !- Complex field \#6

Until: 11:00, 70.0, !- Complex field \#7

Until: 13:00, 50.0, !- Complex field \#8

Until: 14:00, 80.0, !- Complex field \#9

Until: 15:00, 90.0, !- Complex field \#10

Until: 16:00, 80.0, !- Complex field \#11

Until: 24:00, 0.0; !- Complex field \#12

Refrigeration: CompressorRack,

RACK1, ! - Name

Outdoors, !- Heat Rejection Location (Outdoors | Zone)

1.5, !- Design Compressor Rack COP (W/W)

RACK1 CopFuncTempCurve, !- Compressor Rack COP As Function Of Temperature Curve

350, !- Design Condenser Fan Power (W)

RACK1 FanfuncTempCurve, !- Condenser Fan Power Function of Temperature Curve Name

Aircoōled, !- Condenser Type

, !- Water-Cooled Condenser Inlet Node Name

, !- Water-Cooled Condenser Outlet Node Name

, !- Water-Cooled Loop Flow Type

! - Water-Cooled Condenser Outlet Temperature Schedule Name

, !- Water-Cooled Condenser Design Flow Rate

!- Water-Cooled Condenser Maximum Flow Rate

! - Water-Cooled Condenser Maximum Water Outlet Temperature

, !- Water-Cooled Condenser Minimum Water Inlet Temperature

, !- Evaporative Condenser Availability Schedule Name

, !- Evaporative Condenser Effectiveness

!- Evaporative Condenser Air Flow Rate

!- Basin Heater Capacity (W/K)

!- Basin Heater Setpoint Temperature (C)

! - Design Evaporative Condenser Water Pump Power

, !- Evaporative Water Supply Tank Name

RACK1 CondenserNode, !- Condenser Air Inlet Node Name

Refrigeration, !- End-Use Subcategory 
Kitchen_WalkInFreezer_Case:1, !- Refrigeration Case Name or CaseList Name ; !- Heāt Rejection zōne Name

\section{Curve: Quadratic,}

RACK1_FanFuncTempCurve, ! - Name

$0.0, \overline{!}-$ Coefficient 1 Constant

0.0286, !- Coefficient2 $x$

0.0, !- Coefficient $3 x * 2$

0.0, ! - Minimum Value of $\mathrm{x}$

35.0; !- Maximum Value of $\mathrm{x}$

Curve: Quadratic,

RACK1 CopFuncTempCurve, !- Name

$1.760 \overline{3}$, !- Coefficient1 Constant

-0.0377, !- Coefficient2 $x$

0.0004, !- Coefficient $3 x * \star 2$

10.0, !- Minimum Value of $x$

35.0; ! - Maximum Value of $\mathrm{x}$

Refrigeration: CompressorRack,

RACK2, !- Name

Outdoors, !- Heat Rejection Location (Outdoors | Zone)

3, !- Design Compressor Rack COP (W/W)

RACK2_CopFunctempCurve, !-Compressor Rack COP As Function of Temperature Curve

350, !- Design Condenser Fan Power (W)

, !- Condenser Fan Power Function of Temperature Curve Name

Aircooled, !- Condenser Type

, !- Water-Cooled Condenser Inlet Node Name

, !- Water-Cooled Condenser Outlet Node Name

, !-Water-Cooled Loop Flow Type

, !- Water-Cooled Condenser Outlet Temperature Schedule Name

, !- Water-Cooled Condenser Design Flow Rate

! - Water-Cooled Condenser Maximum Flow Rate

, !- Water-Cooled Condenser Maximum Water Outlet Temperature

, !-Water-Cooled Condenser Minimum Water Inlet Temperature

!- Evaporative Condenser Availability Schedule Name

, !- Evaporative Condenser Effectiveness

! - Evaporative Condenser Air Flow Rate

! - Basin Heater Capacity (W/K)

!- Basin Heater Setpoint Temperature (C)

, !- Design Evaporative Condenser Water Pump Power 
, !- Evaporative Water Supply Tank Name

RACK2_CondenserNode, !- Condenser Air Inlet Node Name

Refrigeration, !- End-Use Subcategory

Kitchen_SelfContainedDisplayCase_Case:2, !- Refrigeration Case Name or CaseList Name

; !- Heàt Rejection Zone Name

Curve: Quadratic,

RACK2 CopFuncTempCurve, !- Name

1.0, !- Coefficient1 Constant

0.0, !- Coefficient2 $x$

0.0, !- Coefficient $3 x * * 2$

0.0, ! - Minimum Value of $x$

50.0; ! - Maximum Value of $x$

\section{Secondary School}

Refrigeration: Case,

Kitchen Flr 2 WalkInFreezer Case:1, !- Name

ALWAYS_ON, !- Availablility Schedule

Kitchen Flr 2, !- Zone Name

23.88, !- Rāted Ambient Temperature (C)

55.0, !- Rated Ambient Relative Humidity (\%)

734, !- Rated Total Cooling Capacity per Unit length $(\mathrm{W} / \mathrm{m})$

0.1, !- Rated Latent Heat Ratio

0.4, ! - Rated Runtime Fraction

7.32, !- Case Length (m)

-23, !- Case Operating Temperature (C)

CaseTemperatureMethod, !- Latent Case Credit Curve Type

Kitchen_Flr_2_WalkInFreezer_Case:1_LatentCaseCreditCurve, !- Latent Case Credit Curve Name

68.3, !- Standard Case Fan Power per Unit Length $(\mathrm{W} / \mathrm{m})$

172.2, !- Operating Case Fan Power per Unit Length $(\mathrm{W} / \mathrm{m})$

33, !- Standard Case Lighting Power per Unit Length $(\mathrm{W} / \mathrm{m})$

28.1, !- Installed Case Lighting Power per Unit Length $(\mathrm{W} / \mathrm{m})$

BLDG_LIGHT_SCH, !- Case Lighting Schedule Name

1, !- Fraction of Lighting Energy To Case

0.0, !- Case Anti-Sweat Heater Power per Unit Length ( $\mathrm{W} / \mathrm{m})$

0.0, !- Minimum Anti-Sweat Heater Power per Unit Length $(\mathrm{W} / \mathrm{m})$

None, !-Anti-Sweat Heater Control Type (******)

0.0, !- Humidity At Zero Anti-Sweat Heater Energy (\%)

0.0, !- Case Height (m)

0.0, !- Fraction of Anti-Sweat Heater Energy To Case ()

410, !- Case Defrost Power per Unit Length (W/m)

This report is available at no cost from the National Renewable Energy Laboratory at www.nrel.gov/publications. 
Electric, !- Case Defrost Type

Kitchen_Flr_2_WalkInFreezer_Case:1_DefrostSchedule, !- Case Defrost Schedule Name

Kitchen Flr 2 WalkInFreezer Case:1 DefrostDripDownSchedule, !- Case Defrost Drip-Down Schedule

None, !'- De $\bar{f} r \overline{o s t}$ Energy Correction Curve Type

, !- Defrost Energy Correction Curve Name

0.0, !- Under Case HVAC Return Air Fraction ()

Kitchen_Flr_2_WalkInFreezer_Case:1_RestockSchedule, !- Refrigerated Case Restocking Schedule Name

Kitchen_Flr_2 WalkInFreezer_Case:1_CaseCreditSchedule; !- Case Credit Fraction Schedule Name

Curve:Cubic,

Kitchen_Flr 2 WalkInFreezer_Case:1_LatentCaseCreditCurve, !- Name

$0.0236,-$ ! $-\overline{C o e f f i c i e n t} 1$ Constant

0.0006, !- Coefficient2 x

0.0000, !- Coefficient $3 x * * 2$

0.0000, !- Coefficient $4 x * \star 3$

-35.0, !- Minimum Value of $x$

$20.0 ;$ ! - Maximum Value of $\mathrm{x}$

Schedule: Compact,

Kitchen_Flr_2_WalkInFreezer_Case:1_DefrostSchedule, !- Name

ON/OFF, ! - Schedule type

Through: 12/31, !- Complex field \#1

For:AllDays, !- Complex field \#2

Interpolate:Yes, !- Complex field \#3

Until: 11:00, 0, !- Complex field \#4

Until: 11:20, 1, !-Complex field \#5

Until: 23:00, 0, !- Complex field \#6

Until: 23:20, 1, !-Complex field \#

Until: 24:00, 0; !- Complex field \#8

Schedule: Compact,

Kitchen_Flr_2_WalkInFreezer_Case:1_DefrostDripDownSchedule, !- Name

ON/OFF, !- Schedule type

Through: 12/31, !- Complex field \#1

For:AllDays, !- Complex field \#2

Interpolate:Yes, !- Complex field \#3

Until: 11:00, 0, !- Complex field \#4

Until: 11:30, 1, !-Complex field \#5

Until: 23:00, 0, !- Complex field \#6

Until: 23:30, 1, !- Complex field \#7

Until: 24:00, 0; !- Complex field \#8

This report is available at no cost from the National Renewable Energy Laboratory at www.nrel.gov/publications. 
Curve:Cubic,

Kitchen Flr 2 WalkInFreezer Case: 1 DefrostEnergyCorrectionCurve, !- Name

$0.0236, \overline{\text { ! }}$ - Coéfficient1 Constant

0.0006, !- Coefficient2 $x$

0.0000, !- Coefficient $3 x * * 2$

0.0000, !- Coefficient $4 x^{* * 3}$

-35.0, !- Minimum Value of $x$

$20.0 ;$ ! - Maximum Value of $\mathrm{x}$

Schedule: Compact,

Kitchen_Flr_2_WalkInFreezer_Case:1_RestockSchedule, !- Name

Any Number, !- Schedule type

Through: 12/31, !- Complex field \#1

For: Tuesday Friday, !- Complex field \#2

Until: 4:00, 0.0, !- Complex field \#3

Until: 5:00, 725.0, !- Complex field \#4

Until: 6:00, 417.0, !-Complex field \#5

Until: 7:00, 290.0, !-Complex field \#6

Until: 24:00, 0.0, !- Complex field \#7

For: AllotherDays, !- Complex field \#8

Until: 4:00, 0.0, !- Complex field \#9

Until: 5:00, 125.0, !- Complex field \#10

Until: 6:00, 117.0, !-Complex field \#11

Until: 7:00, 90.0, !- Complex field \#12

Until: 19:00, 0.0, !- Complex field \#13

Until: 20:00, 125.0, !-Complex field \#14

Until: 21:00, 117.0, !-Complex field \#15

Until: 22:00, 90.0, !- Complex field \#16

Until: 24:00, 0.0; !- Complex field \#17

Schedule: Compact,

Kitchen Flr 2 WalkInFreezer Case:1 CaseCreditSchedule, !- Name

Fraction, !- $\overline{\text { Schedule type }}$

Through: 12/31, !- Complex field \#1

For:AllDays, !- Complex field \#2

Interpolate:No, !- Complex field \#3

Until: $7: 00,0.2$, !-Complex field \#4

Until: 21:00, 0.4, !-Complex field \#5

Until: 24:00, 0.2; !- Complex field \#6

This report is available at no cost from the National Renewable Energy Laboratory at www.nrel.gov/publications. 
Refrigeration:Case,

Kitchen_Flr_2_SelfContainedDisplayCase_Case:2, !- Name

ALWAYS ON, !- Availablility Schedule

Kitcheñ_Flr_2, !- Zone Name

23.88, !- Rāted Ambient Temperature (C)

55.0, !- Rated Ambient Relative Humidity (\%)

734, !- Rated Total Cooling Capacity per Unit length $(\mathrm{W} / \mathrm{m})$

0.08, !- Rated Latent Heat Ratio

0.85, ! - Rated Runtime Fraction

7.32, !- Case Length (m)

2, ! - Case Operating Temperature (C)

CaseTemperatureMethod, !- Latent Case Credit Curve Type

Kitchen Flr 2 SelfContainedDisplayCase Case:2 LatentCaseCreditCurve, !- Latent Case Credit Curve Name

55, !- Standārd Case Fan Power per Unit Length $(\mathrm{W} / \mathrm{m})$

40.0, !- Operating Case Fan Power per Unit Length ( $\mathrm{W} / \mathrm{m})$

33, !- Standard Case Lighting Power per Unit Length $(\mathrm{W} / \mathrm{m})$

75.0, !- Installed Case Lighting Power per Unit Length $(\mathrm{W} / \mathrm{m})$

BLDG LIGHT SCH, !- Case Lighting Schedule Name

1, !- Fraction of Lighting Energy To Case

0.0, !- Case Anti-Sweat Heater Power per Unit Length $(\mathrm{W} / \mathrm{m})$

0.0 , !- Minimum Anti-Sweat Heater Power per Unit Length $(\mathrm{W} / \mathrm{m})$

None, !- Anti-Sweat Heater Control Type $(* * * * * *)$

0.0, !- Humidity At Zero Anti-Sweat Heater Energy (\%)

0.0, !- Case Height (m)

0.2 , !- Fraction of Anti-Sweat Heater Energy To Case ()

0 , !- Case Defrost Power per Unit Length $(\mathrm{W} / \mathrm{m})$

None, !- Case Defrost Type $(* \star \star \star * \star * *)$

, - Case Defrost Schedule Name

, !- Case Defrost Drip-Down Schedule

None, !- Defrost Energy Correction Curve Type

, !- Defrost Energy Correction Curve Name

0.05, !- Under Case HVAC Return Air Fraction ()

Kitchen Flr 2 SelfContainedDisplayCase Case:2 RestockSchedule; !- Refrigerated Case Restocking Schedule Name

Curve:Cubic,

Kitchen_Flr_2_SelfContainedDisplayCase_Case:2_LatentCaseCreditCurve, ! - Name

0.026526281, !- Coefficient1 Constant

0.001078032, !- Coefficient2 $\mathrm{x}$

0.0000602558, ! - Coefficient3 $x * * 2$

0.00000123732, ! - Coefficient $4 x * * 3$

This report is available at no cost from the National Renewable Energy Laboratory at www.nrel.gov/publications. 
-35.0, !- Minimum Value of $\mathrm{x}$

$20.0 ;$ ! - Maximum Value of $\mathrm{x}$

Curve:Cubic,

Kitchen_Flr_2_SelfContainedDisplayCase_Case:2_DefrostEnergyCorrectionCurve, !- Name

0.0236 , !- Coefficient1 Constant

0.0006, !- Coefficient2 x

$0.0000, !-$ Coefficient $3 x * * 2$

0.0000, ! - Coefficient $4 x * * 3$

-35.0, ! - Minimum Value of $x$

20.0; !- Maximum Value of $x$

Schedule: Compact,

Kitchen_Flr_2_SelfContainedDisplayCase_Case:2_RestockSchedule, !- Name

Any Number, !- Schedule type

Through: 12/31, !- Complex field \#1

For:AllDays, !- Complex field \#2

Until: 6:00, 0.0, !- Complex field \#3

Until: 7:00, 50.0, !- Complex field \#4

Until: 9:00, 70.0, !-Complex field \#5

Until: 10:00, 80.0, !- Complex field \#6

Until: 11:00, 70.0, !- Complex field \#7

Until: 13:00, 50.0, !- Complex field \#8

Until: 14:00, 80.0, !- Complex field \#9

Until: 15:00, 90.0, !- Complex field \#10

Until: 16:00,80.0, !-Complex field \#11

Until: 24:00, 0.0; !- Complex field \#12

Refrigeration: CompressorRack,

RACK1, ! - Name

Outdoors, !- Heat Rejection Location (Outdoors | Zone)

1.5, !- Design Compressor Rack COP (W/W)

RACK1 CopFuncTempCurve, !-Compressor Rack COP As Function Of Temperature Curve

$750, \overline{!}-$ Design Condenser Fan Power (W)

RACK1 FanFuncTempCurve, !- Condenser Fan Power Function of Temperature Curve Name

AirCooled, !- Condenser Type

, !- Water-Cooled Condenser Inlet Node Name

!- Water-Cooled Condenser Outlet Node Name

, !-Water-Cooled Loop Flow Type

, !- Water-Cooled Condenser Outlet Temperature Schedule Name

, !- Water-Cooled Condenser Design Flow Rate

This report is available at no cost from the National Renewable Energy Laboratory at www.nrel.gov/publications. 
, !- Water-Cooled Condenser Maximum Flow Rate

, !- Water-Cooled Condenser Maximum Water Outlet Temperature

, !- Water-Cooled Condenser Minimum Water Inlet Temperature

, !- Evaporative Condenser Availability Schedule Name

, !- Evaporative Condenser Effectiveness

! - Evaporative Condenser Air Flow Rate

, !- Basin Heater Capacity (W/K)

, !- Basin Heater Setpoint Temperature (C)

, !- Design Evaporative Condenser Water Pump Power

, !- Evaporative Water Supply Tank Name

RACK1 CondenserNode, !- Condenser Air Inlet Node Name

Refrigeration, !- End-Use Subcategory

Kitchen Flr 2 WalkInFreezer Case:1, !- Refrigeration Case Name or CaseList Name

; !- Heāt Rējēction Zone Name

Curve: Quadratic,

RACK1_FanFuncTempCurve, !- Name

0.0, !- Coefficient1 Constant

0.0286, !- Coefficient2 x

0.0, ! - Coefficient3 $x * * 2$

0.0, ! - Minimum Value of $x$

35.0; !- Maximum Value of $x$

Curve: Quadratic,

RACK1 CopFunctempCurve, !- Name

1.7603, !- Coefficient1 Constant

-0.0377, !- Coefficient2 $\mathrm{x}$

0.0004, ! - Coefficient $3 x^{*} * 2$

10.0, !- Minimum Value of $x$

$35.0 ;$ ! - Maximum Value of $x$

Refrigeration:CompressorRack,

RACK2, ! - Name

Outdoors, !- Heat Rejection Location (Outdoors | Zone)

3, !- Design Compressor Rack COP (W/W)

RACK2 CopFunctempCurve, !- Compressor Rack COP As Function Of Temperature Curve

750, ! - Design Condenser Fan Power (W)

!- Condenser Fan Power Function of Temperature Curve Name

Aircooled, !- Condenser Type

, !-Water-Cooled Condenser Inlet Node Name

, !- Water-Cooled Condenser Outlet Node Name

This report is available at no cost from the National Renewable Energy Laboratory at www.nrel.gov/publications. 
, !- Water-Cooled Loop Flow Type

, !- Water-Cooled Condenser Outlet Temperature Schedule Name

, !- Water-Cooled Condenser Design Flow Rate

, !- Water-Cooled Condenser Maximum Flow Rate

, !-Water-Cooled Condenser Maximum Water Outlet Temperature

, !- Water-Cooled Condenser Minimum Water Inlet Temperature

, !- Evaporative Condenser Availability Schedule Name

! - Evaporative Condenser Effectiveness

, !- Evaporative Condenser Air Flow Rate

, !- Basin Heater Capacity (W/K)

, - Basin Heater Setpoint Temperature (C)

, !- Design Evaporative Condenser Water Pump Power

!- Evaporative Water Supply Tank Name

RACK2 CondenserNode, !- Condenser Air Inlet Node Name

Refrigeration, !- End-Use Subcategory

Kitchen_Flr_2_SelfContainedDisplayCase_Case:2, !- Refrigeration Case Name or CaseList Name ; !- Heāt Rējection Zone Name

Curve: Quadratic,

RACK2 CopFuncTempCurve, !- Name

1.0, !- Coefficient1 Constant

0.0, !- Coefficient2 $\mathrm{x}$

0.0, !- Coefficient $3 x * * 2$

0.0, !- Minimum Value of $\mathrm{x}$

$50.0 ;$ ! - Maximum Value of $x$ 


\section{Appendix C. EnergyPlus Heat Pump Performance Tables}

\section{General}

Curve:Quadratic,

ConstantQuadtratic,

1 ,

0,

0,

0,

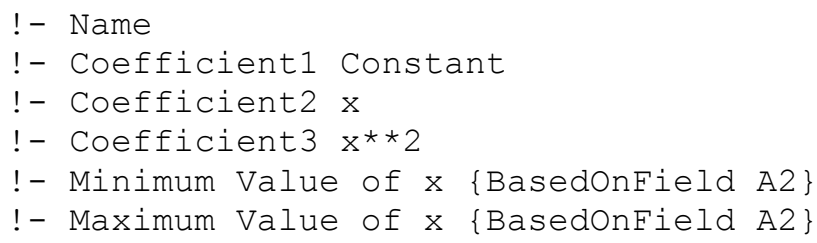

!- Coefficient1 Constant

!- Coefficient2 $x$

1 - Coefficient $3 x * * 2$

!- Minimum Value of $x$ \{BasedOnField A2

!- Maximum Value of x \{BasedOnField A2

Curve:Biquadratic,

ConstantBiquadtratic,

! - Name

1 ,

0,

!- Coefficient1 Constant

!- Coefficient2 $x$

!- Coefficient $3 x^{* * 2}$

!- Coefficient4 y

!- Coefficient5 $y^{\star *} 2$

! - Coefficient $6 x^{*} y$

!- Minimum Value of $x$ BBasedOnField A2

!- Maximum Value of $x$ \{BasedOnField A2

!- Minimum Value of y \{BasedOnField A3

!- Maximum Value of y \{BasedOnField A3\}

Curve: Quadratic,

PLFfPLR,

0.85 ,

0.15 ,

0 ,

0 ,

1

\section{Heating}

Table:TwoIndependentVariables,
PartLoadHtgCapfTemp,
Biquadratic,
! - Curve Type

LagrangeInterpolationLinearExtrapolation, !- Interpolation Method 0 ,

!- Minimum Value of X \{BasedOnField A4 100 ,

! - Maximum Value of X \{BasedOnField A4\}

0 ,

!- Minimum Value of Y \{BasedOnField A5 


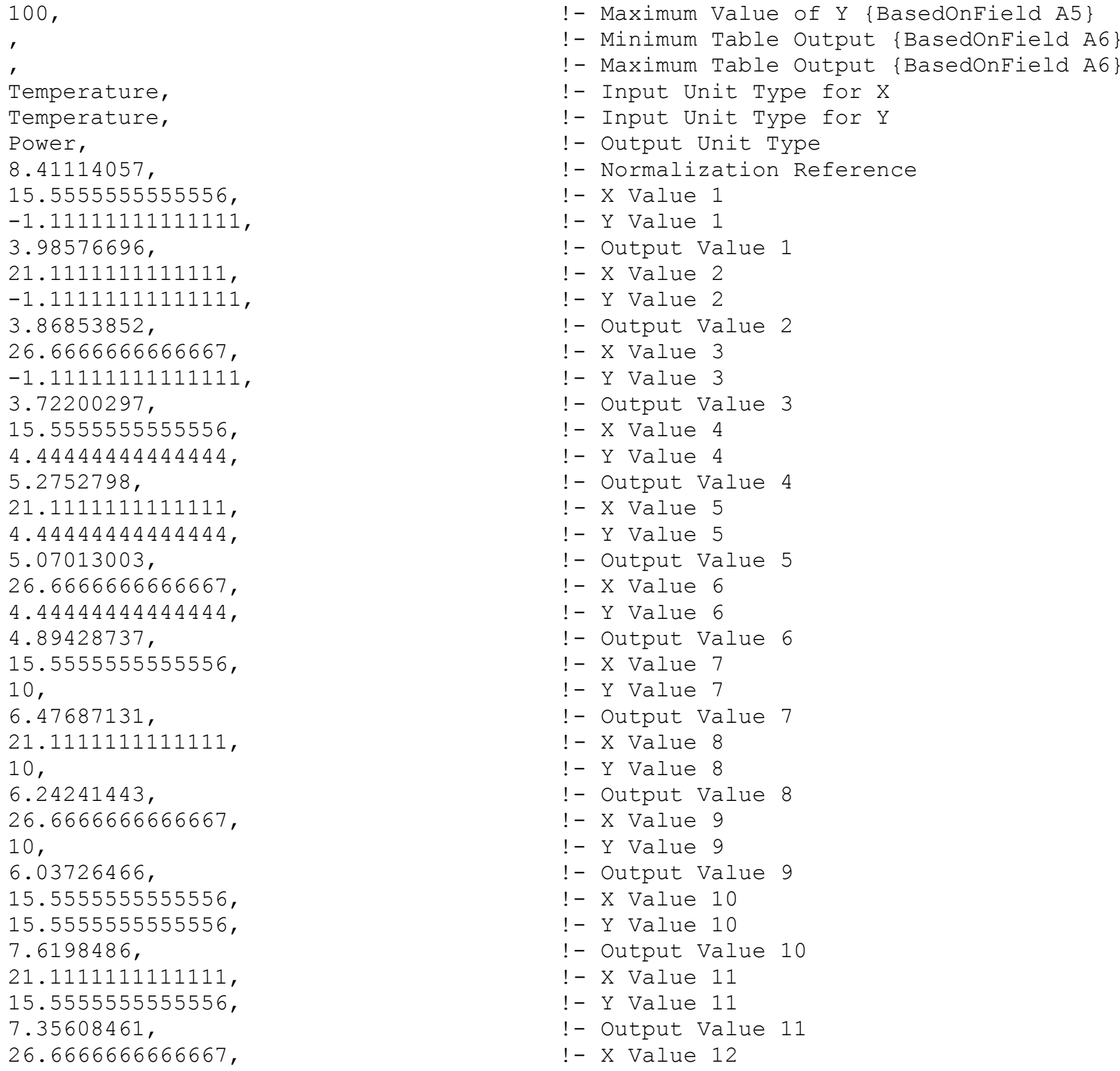

100,

Temperature,

Temperature,

Power,

8.41114057,

15.5555555555556 ,

-1.11111111111111 , 3. 98576696 ,

21.1111111111111,

-1.11111111111111 ,

3.86853852

26.6666666666667 ,

-1.11111111111111 ,

3. 72200297 ,

15.5555555555556 ,

4.44444444444444 ,

5.2752798,

21.1111111111111,

4. 44444444444444 ,

5.07013003,

26.6666666666667 ,

4. 44444444444444 ,

4.89428737 ,

15.5555555555556 ,

10

6.47687131

21.1111111111111,

10 ,

6.24241443

26.6666666666667 ,

10,

6.03726466 ,

15.5555555555556 ,

15.5555555555556 ,

7.6198486,

21.1111111111111,

15.5555555555556 ,

7.35608461

26.6666666666667 ,

!- Maximum Value of Y \{BasedOnField A5

!- Minimum Table Output \{BasedOnField A6

!- Maximum Table Output BasedOnField A6

!- Input Unit Type for X

!- Input Unit Type for $Y$

!- Output Unit Type

! - Normalization Reference

! - X Value 1

! - Y Value 1

!- Output Value 1

! - X Value 2

! - Y Value 2

- Output Value 2

! - X Value 3

! - Y Value 3

! - Output Value 3

! - X Value 4

! - Y Value 4

! - Output Value 4

! - X Value 5

! - Y Value 5

! - Output Value 5

! - X Value 6

!- Y Value 6

!- Output Value 6

! - X Value 7

! - Y Value 7

!- Output Value 7

! - X Value 8

! - Y Value 8

!- Output Value 8

! - X Value 9

! - Y Value 9

!- Output Value 9

! - X Value 10

! - Y Value 10

! - Output Value 10

! - X Value 11

! - Y Value 11

! - Output Value 11

! - X Value 12

\section{1}

This report is available at no cost from the National Renewable Energy Laboratory at www.nrel.gov/publications. 


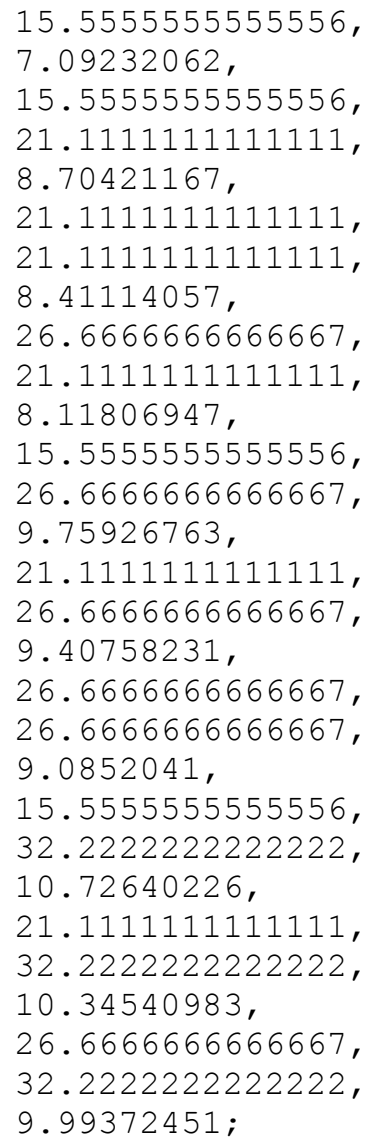

Table: OneIndependentVariable,

PartLoadHtgCapfWaterFlowFrac,

Quadratic,

LagrangeInterpolationLinearExtrapolation 100,
! - Y Value 12

!- Output Value 12

! - X Value 13

! - Y Value 13

! - Output Value 13

! - X Value 14

!- Y Value 14

! - Output Value 14

! - X Value 15

! - Y Value 15

! - Output Value 15

! - X Value 16

! - Y Value 16

!- Output Value 16

! - X Value 17

! - Y Value 17

!- Output Value 17

! - X Value 18

! - Y Value 18

!- Output Value 18

! - X Value 19

! - Y Value 19

!- Output Value 19

! - X Value 20

! - Y Value 20

! - Output Value 20

! - X Value 21

! - Y Value 21

!- Output Value 21

! - Name

!- Curve Type

!- Minimum Value of X $\{$ BasedOnField A4

!- Maximum Value of X $\{$ BasedOnField A4\}

!- Minimum Table Output \{BasedOnField A5

!- Maximum Table Output BasedOnField A5

!- Input Unit Type for $\mathrm{X}$

!- Output Unit Type

! - Normalization Reference

\section{2}

This report is available at no cost from the National Renewable Energy Laboratory at www.nrel.gov/publications. 


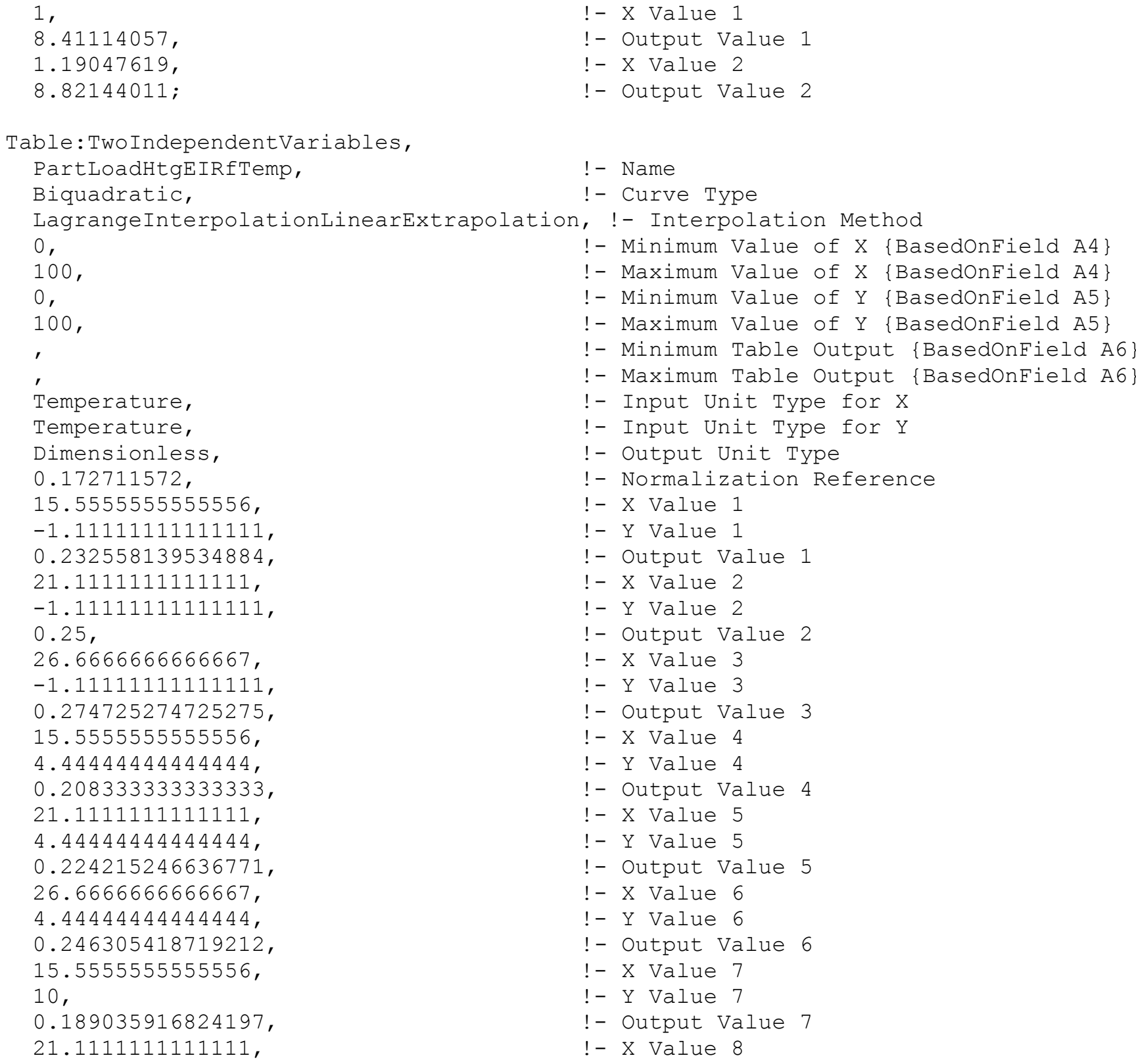


10 ,

0.203665987780041 , 26.66666666666667 ,

10 ,

0.223713646532438 , 15.5555555555556,

15.5555555555556,

0.17361111111111 ,

21.1111111111111,

15.5555555555556,

0.186567164179104 , 26.6666666666667 ,

15.5555555555556,

0.205338809034908 , 15.5555555555556,

21.1111111111111,

0.160513643659711 ,

21.1111111111111,

21.1111111111111,

0.172711571675302

26.6666666666667 ,

21.1111111111111,

0.189753320683112 ,

15.5555555555556 ,

26.6666666666667 ,

0.149700598802395 ,

21.1111111111111 ,

26.6666666666667 ,

0.161030595813205 ,

26.6666666666667 ,

26.6666666666667 ,

0.176991150442478 ,

15.5555555555556,

32.2222222222222,

0.140252454417952 ,

21.1111111111111,

32.2222222222222,

0.151057401812689 ,

26.6666666666667 ,

32.2222222222222 ,

0.165837479270315 ;
!- Y Value 8

!- Output Value 8

! - X Value 9

! - Y Value 9

!- Output Value 9

! - X Value 10

!- Y Value 10

! - Output Value 10

! - X Value 11

! - Y Value 11

! - Output Value 11

! - X Value 12

! - Y Value 12

!- Output Value 12

! - X Value 13

! - Y Value 13

!- Output Value 13

! - X Value 14

!- Y Value 14

!- Output Value 14

! - X Value 15

! - Y Value 15

!- Output Value 15

!- X Value 16

! - Y Value 16

!- Output Value 16

! - X Value 17

! - Y Value 17

! - Output Value 17

! - X Value 18

! - Y Value 18

!- Output Value 18

! - X Value 19

!- Y Value 19

!- Output Value 19

! - X Value 20

! - Y Value 20

!- Output Value 20

! - X Value 21

! - Y Value 21

!- Output Value 21

\section{4}

This report is available at no cost from the National Renewable Energy Laboratory at www.nrel.gov/publications. 


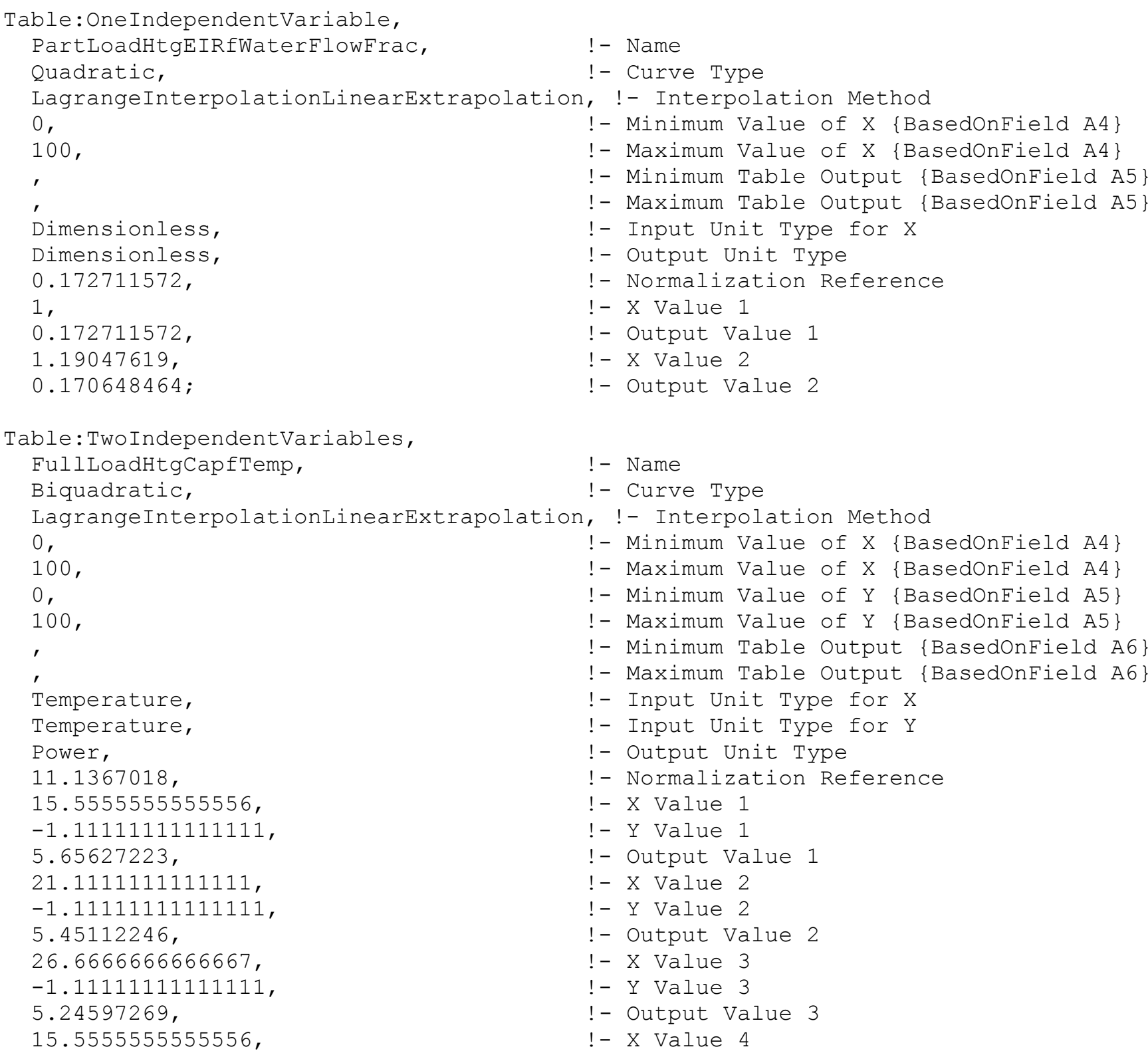

Table:TwoIndependentVariables,
Full LoadHtgCapfTemp,
!- Name
Biquadratic,

! - Curve Type

LagrangeInterpolationLinearExtrapolation, !- Interpolation Method

0 ,

100 ,

0 ,

100 ,

Temperature,

Temperature,

Power,

11.1367018

15.5555555555556 ,

-1.11111111111111 ,

5.65627223

21.1111111111111

$-1.11111111111111$

5.45112246 ,

26.6666666666667

-1.11111111111111 ,

5.24597269

15.5555555555556 ,

!- Minimum Value of X \{BasedOnField A4

! - Maximum Value of X \{BasedOnField A4

!- Minimum Value of $Y$ \{BasedOnField A5

!- Maximum Value of Y \{BasedOnField A5\}

!- Minimum Table Output \{BasedOnField A6

!- Maximum Table Output \{BasedOnField A6\}

!- Input Unit Type for X

! - Input Unit Type for $Y$

!- Output Unit Type

! - Normalization Reference

! - X Value 1

! - Y Value 1

! - Output Value 1

! - X Value 2

! - Y Value 2

! - Output Value 2

! - X Value 3

! - Y Value 3

! - Output Value 3

! - X Value 4 


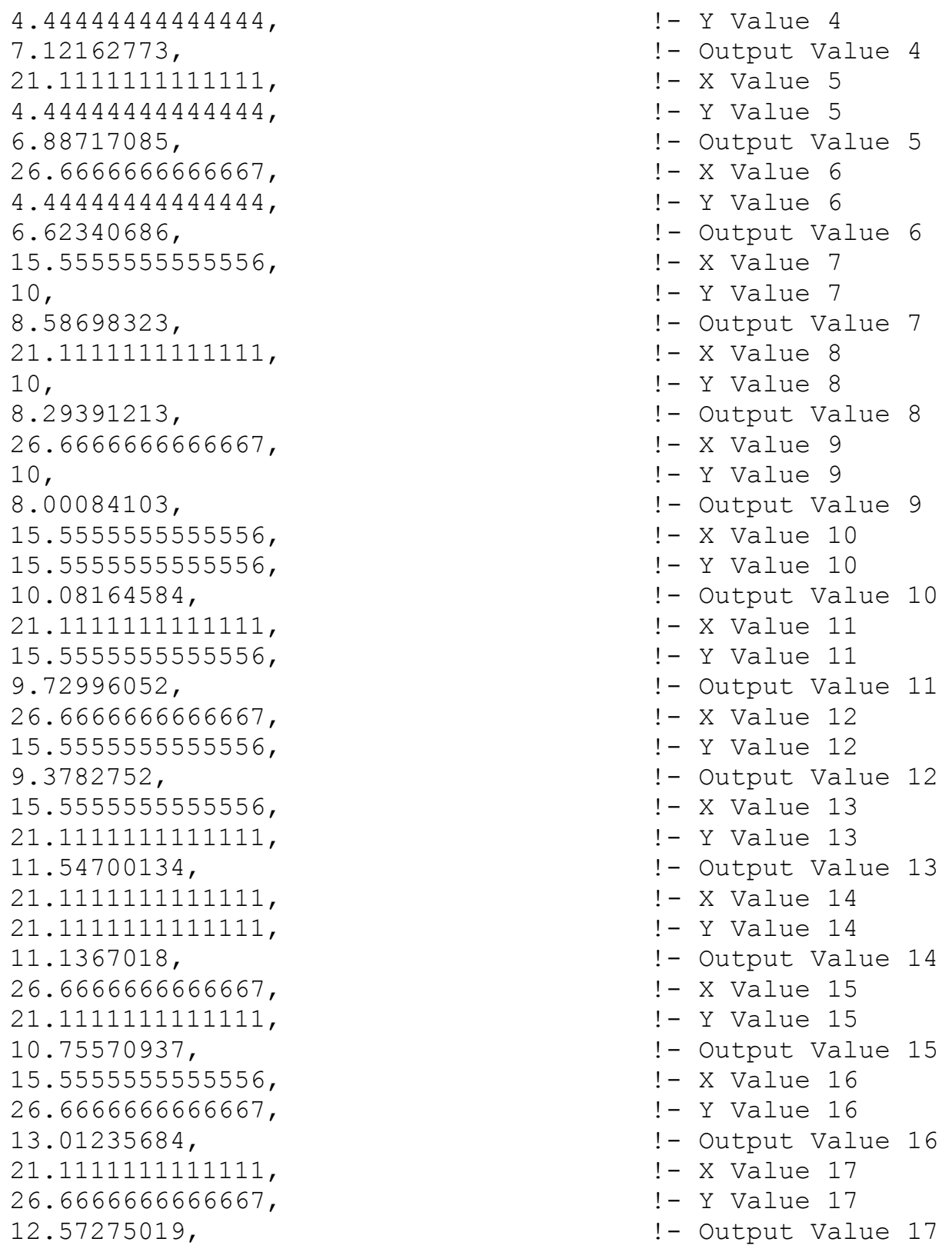




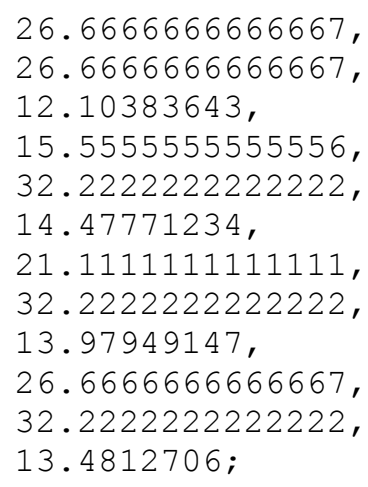

Table:OneIndependentVariable,

FullLoadHtgCapfWaterFlowFrac,

Quadratic, LagrangeInterpolationLinearExtrapolation 0 , 100 ,

Dimensionless,

Power,

11.1367018

1 ,

11.1367018

1.19047619

11.69353689

able:TwoIndependentVariables,
FullLoadHtgEIRfTemp,
Biquadratic,

LagrangeInterpolationLinearExtrapolation, !- Interpolation Method

0 ,

100 ,

0 ,

100,

Temperature,

Temperature,

!- Input Unit Type for X

!- Input Unit Type for $Y$
! - X Value 18

!- Y Value 18

! - Output Value 18

! - X Value 19

! - Y Value 19

!- Output Value 19

! - X Value 20

! - Y Value 20

!- Output Value 20

! - X Value 21

- Y Value 21

!- Output Value 21

! - Name

! - Curve Type

- Minimum Value of $X$ \{BasedonField A4

!- Maximum Value of X \{BasedOnField A4\}

!- Minimum Table Output \{BasedOnField A5\}

!- Maximum Table Output BasedOnField A5

!- Input Unit Type for $X$

!- Output Unit Type

! - Normalization Reference

! - X Value 1

! - Output Value 1

! - X Value 2

!- Output Value 2

!- Minimum Value of $X$ \{BasedOnField A4\}

! - Maximum Value of $X$ \{BasedOnField A4

!- Minimum Value of $Y$ \{BasedOnField A5

!- Maximum Value of $Y$ \{BasedOnField A5\}

!- Minimum Table Output \{BasedOnField A6

!- Maximum Table Output \{BasedOnField A6\} 


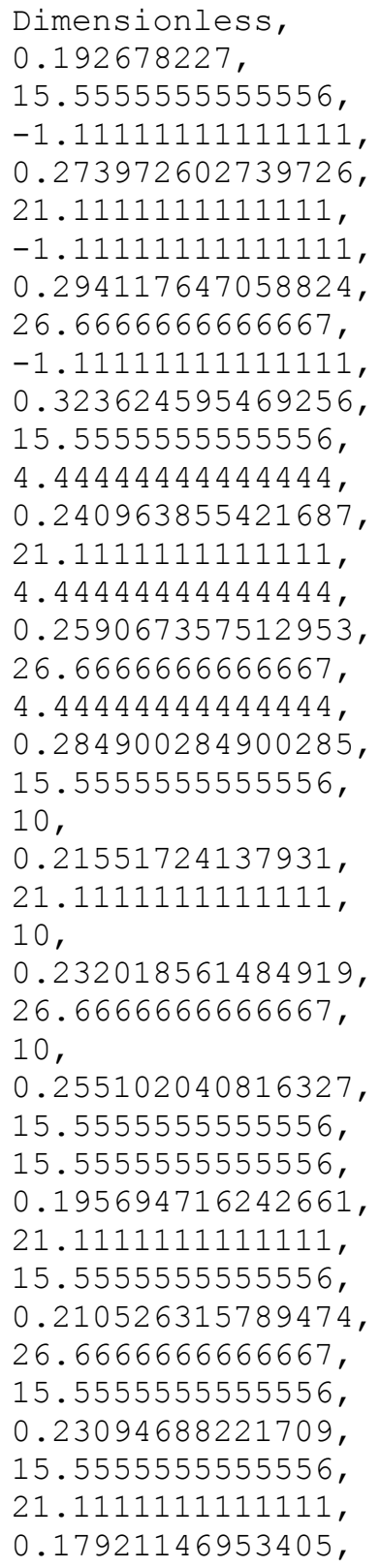

!- Output Value 13 


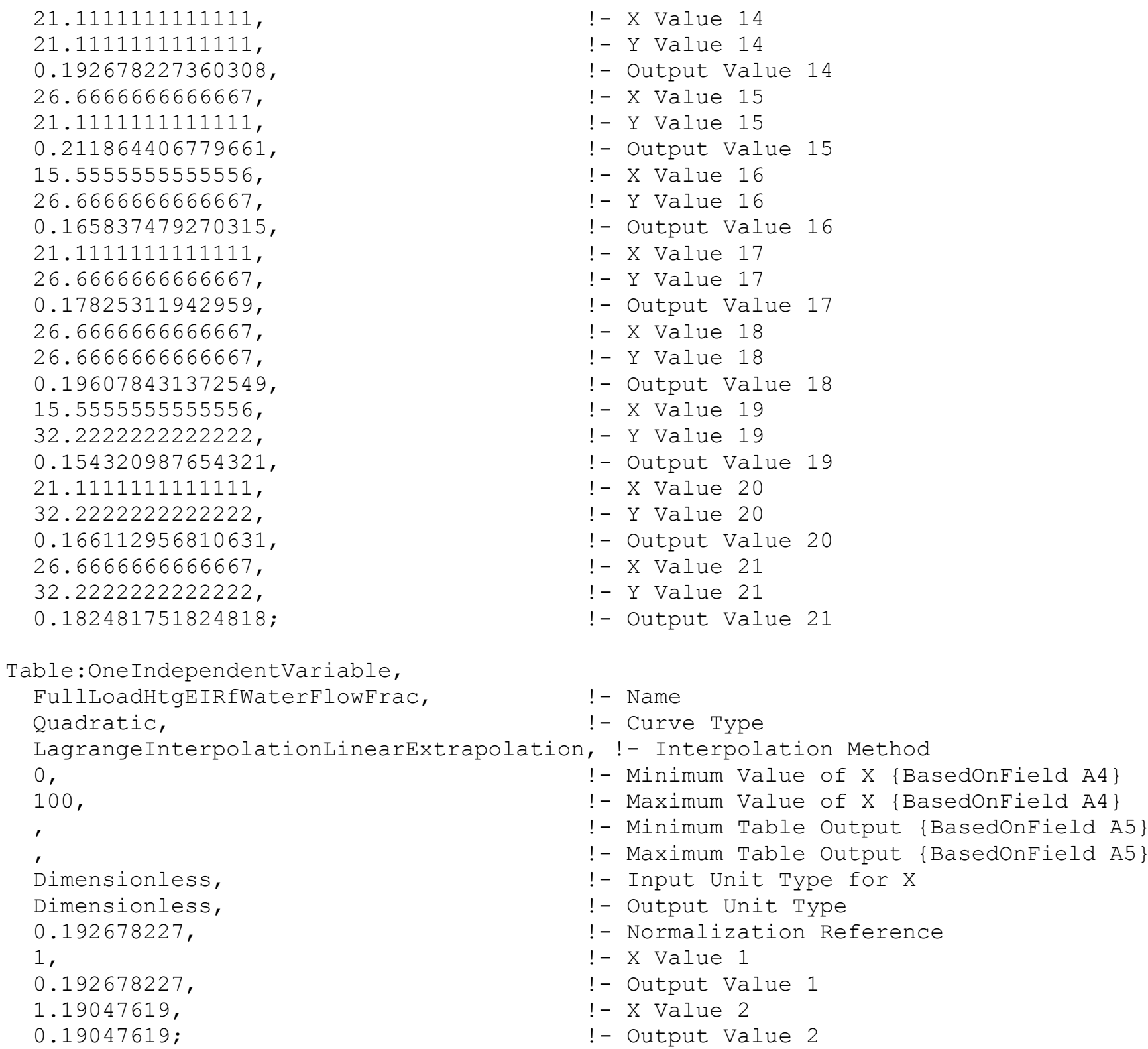

Table:OneIndependentVariable

FullLoadHtgEIRfWaterFlowFrac,

! - Name

! - Curve Type

LagrangeInterpolationLinearExtrapolation, !- Interpolation Method 0 ,

!- Minimum Value of X \{BasedOnField A4

100,

! - Maximum Value of X \{BasedOnField A4

!- Minimum Table Output \{BasedOnField A5

!- Maximum Table Output \{BasedOnField A5

Dimensionless,

Dimensionless,

0.192678227

1 ,

0.192678227

1.19047619 ,

0.19047619 ;

!- Input Unit Type for X

!- Output Unit Type

! - Normalization Reference

! - X Value 1

!- Output Value 1

! - X Value 2

!- Output Value 2 


\section{Cooling}

Table: TwoIndependentVariables,

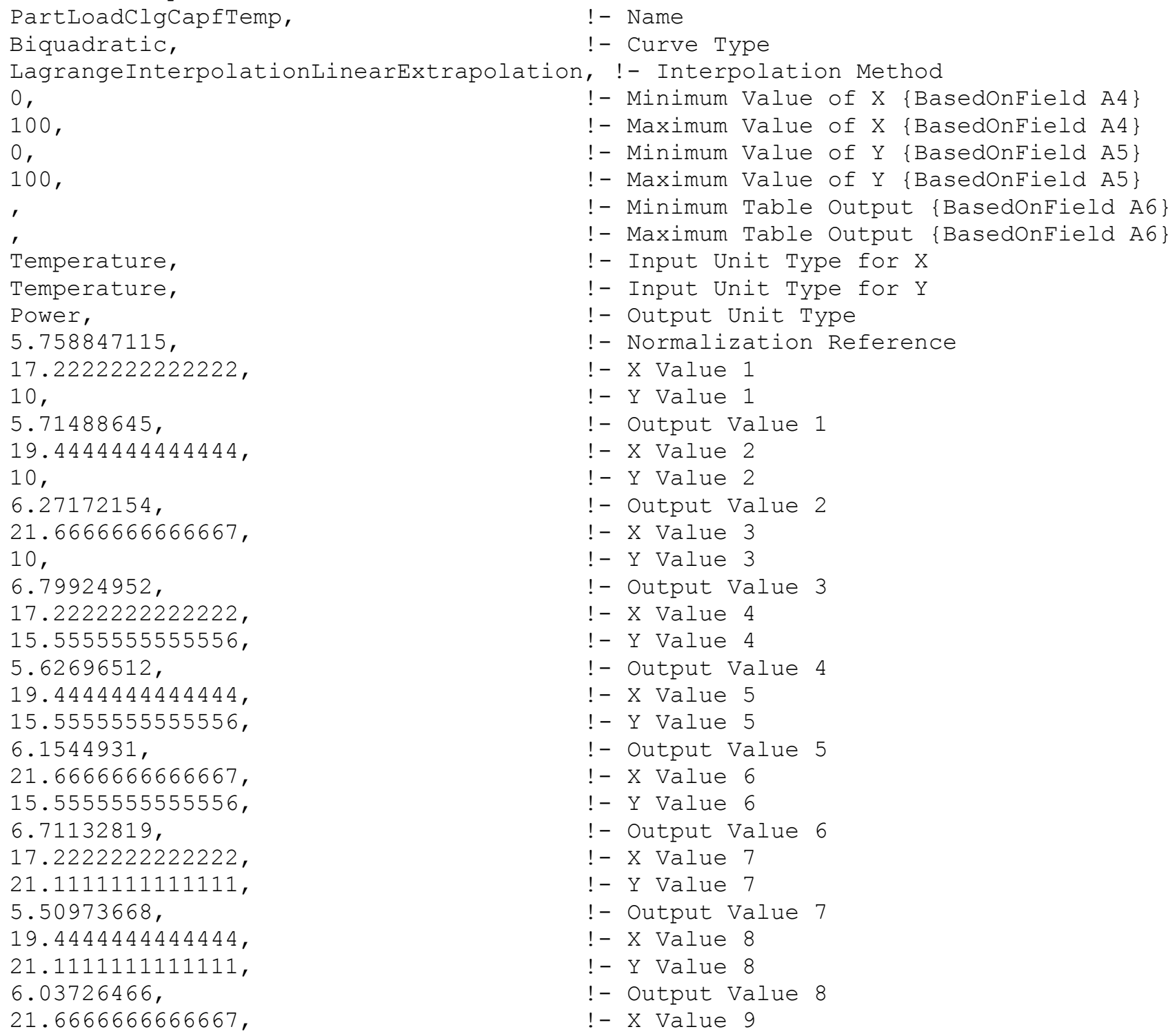




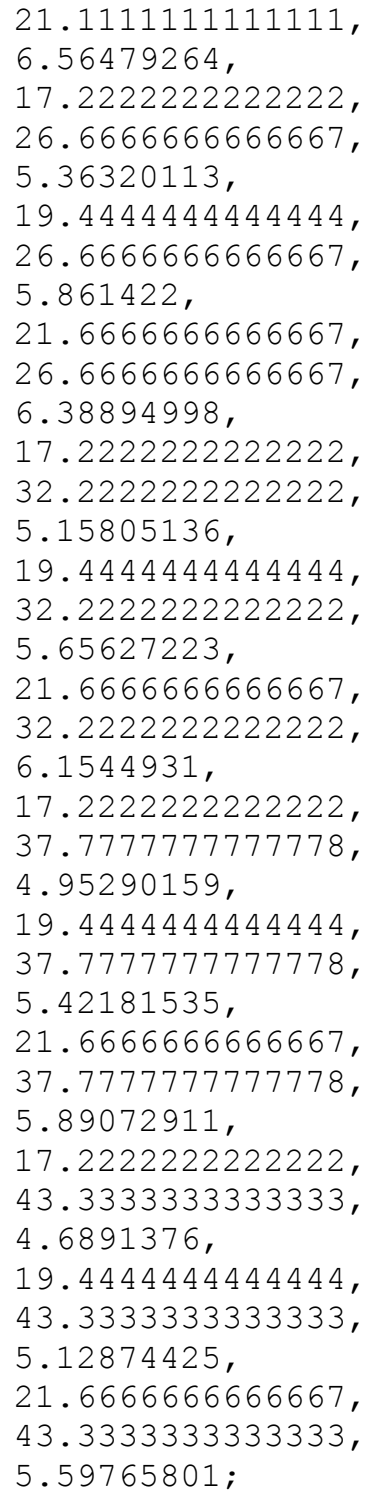

Table: OneIndependentVariable, PartLoadClgCapfWaterFlowFrac,
1-Y Value 9

! - Output Value 9

! - X Value 10

! - Y Value 10

! - Output Value 10

! - X Value 11

! - Y Value 11

! - Output Value 11

! - X Value 12

! - Y Value 12

!- Output Value 12

! - X Value 13

! - Y Value 13

! - Output Value 13

! - X Value 14

I - Y Value 14

! - Output Value 14

! - X Value 15

! - Y Value 15

!- Output Value 15

! - X Value 16

! - Y Value 16

!- Output Value 16

! - X Value 17

! - Y Value 17

! - Output Value 17

! - X Value 18

! - Y Value 18

!- Output Value 18

! - X Value 19

I- Y Value 19

! - Output Value 19

! - X Value 20

! - Y Value 20

!- Output Value 20

! - X Value 21

! - Y Value 21

!- Output Value 21 

Quadratic,
!- Curve Type

LagrangeInterpolationLinearExtrapolation, !- Interpolation Method

!- Minimum Value of X \{BasedOnField A4

100,

!- Maximum Value of X \{BasedOnField A4

Dimensionless,

Power,

!- Minimum Table Output \{BasedOnField A5\}

!- Maximum Table Output \{BasedOnField A5

5.758847115 ,

!- Input Unit Type for X

! - Output Unit Type

1 ,

5.758847115

1. 19047619 ,

5.846768445 ;

! - Normalization Reference

! - X Value 1

!- Output Value 1

! - X Value 2

!- Output Value 2

Table: TwoIndependentVariables,

PartLoadClgEIRfTemp, !- Name

Biquadratic,

! - Curve Type

LagrangeInterpolationLinearExtrapolation, !- Interpolation Method

0 ,

100 ,

0 ,

100,

,

Temperature,

Temperature,

Dimensionless,

0.081746507

17.2222222222222 ,

10 ,

0.0564594715558431 ,

19.4444444444444 ,

10 ,

0.0519256952436662 ,

21.6666666666667 ,

10,

0.0480793474478391 ,

17.222222222222 ,

15.5555555555556 ,

0.0633549316065157 ,

19.4444444444444 ,
!- Minimum Value of X \{BasedOnField A4

! - Maximum Value of X \{BasedOnField A4

!- Minimum Value of Y \{BasedOnField A5

!- Maximum Value of Y \{BasedOnField A5

!- Minimum Table Output \{BasedOnField A6

!- Maximum Table Output \{BasedOnField A6

!- Input Unit Type for X

!- Input Unit Type for Y

!- Output Unit Type

!- Normalization Reference

! - X Value 1

! - Y Value 1

! - Output Value 1

! - X Value 2

!- Y Value 2

!- Output Value 2

! - X Value 3

! - Y Value 3

! - Output Value 3

! - X Value 4

! - Y Value 4

!- Output Value 4

! - X Value 5 

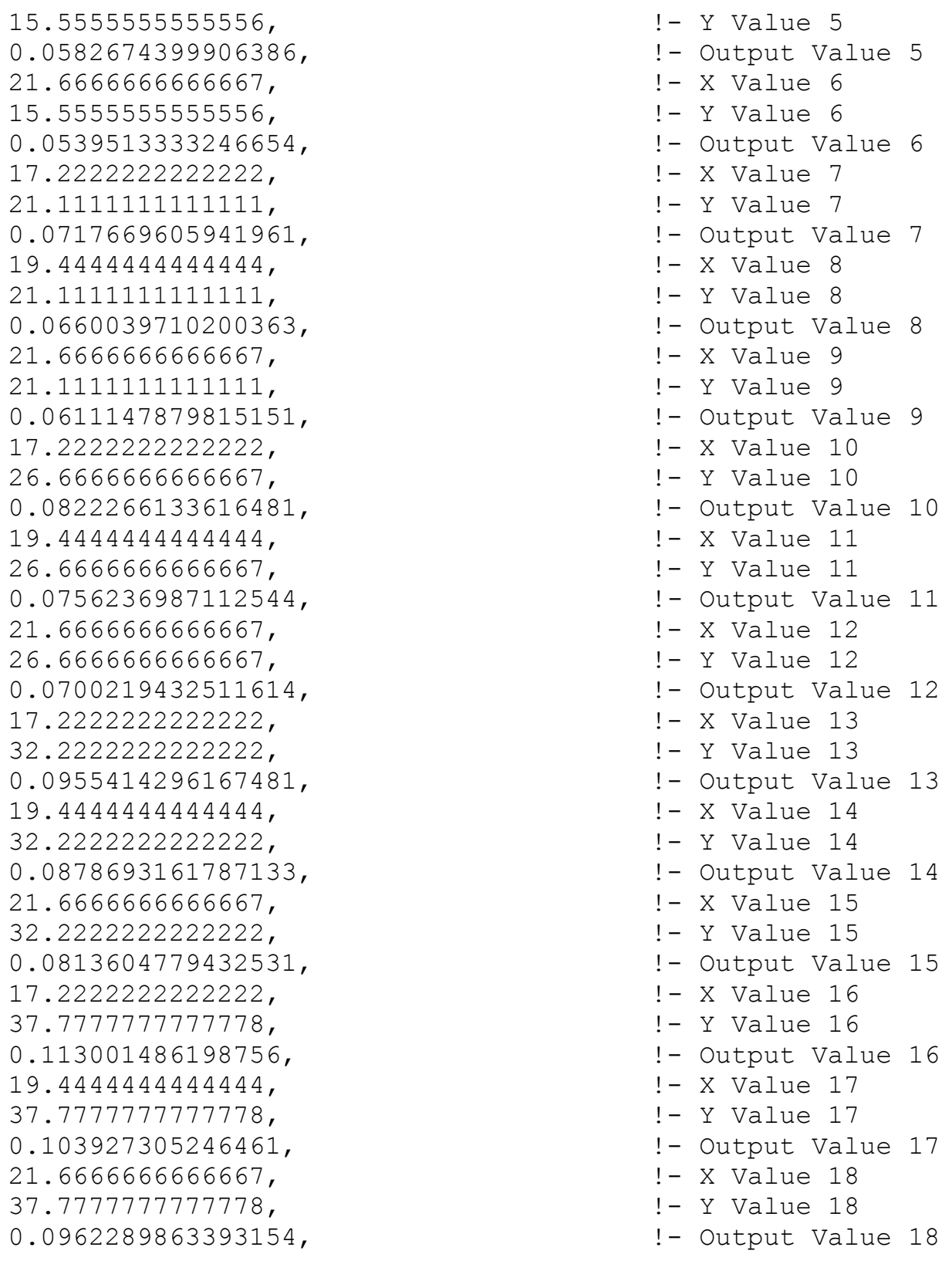


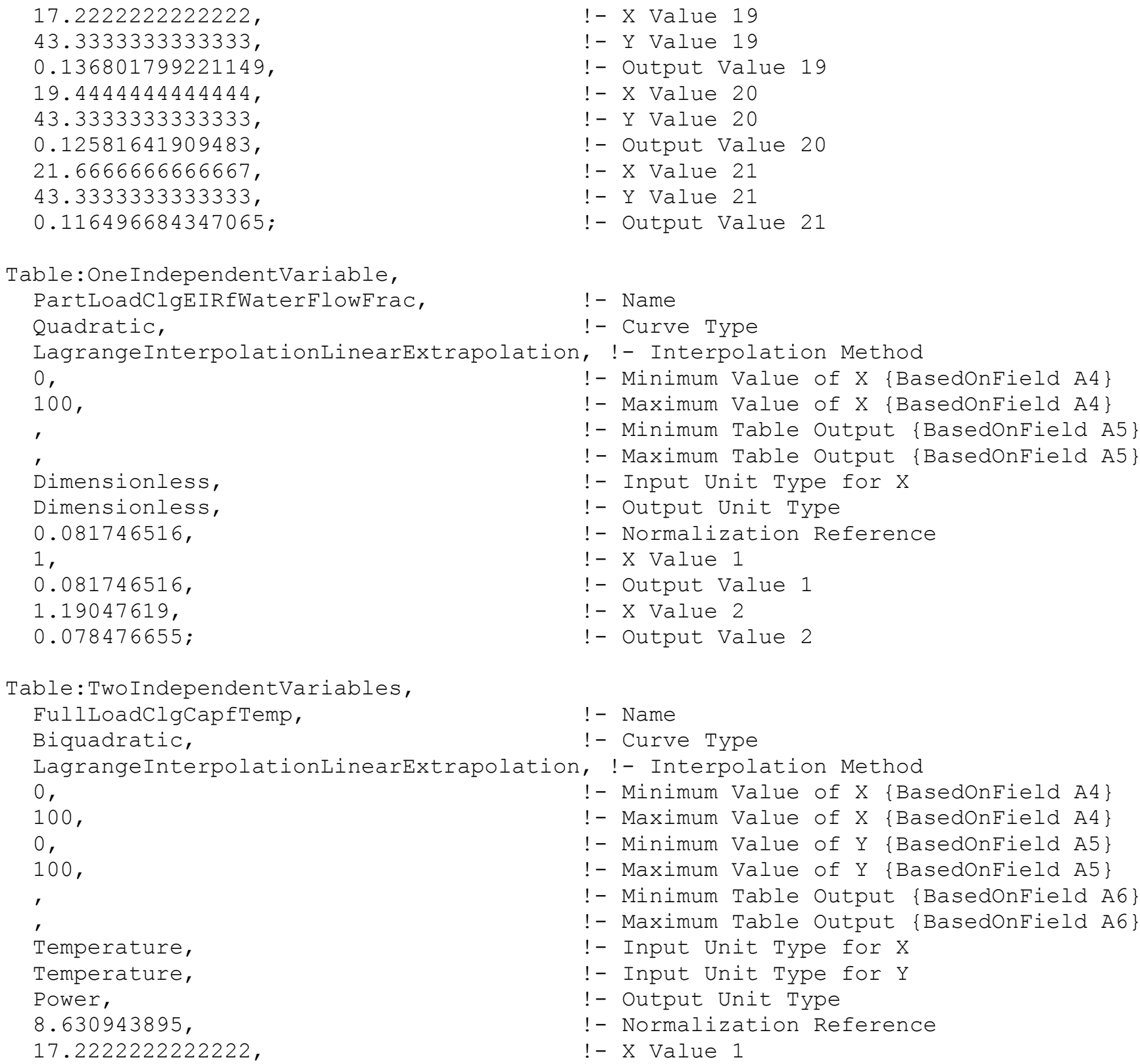

Table: OneIndependentVariable, PartLoadClgEIRfWaterFlowFrac, Quadratic,

! - Name

! - Curve Type

LagrangeInterpolationLinearExtrapolation, !- Interpolation Method 0 ,

!- Minimum Value of X \{BasedOnField A4\}

100,

!- Maximum Value of X \{BasedOnField A4\}

!- Minimum Table Output \{BasedOnField A5

,

Dimensionless,

Dimensionless,

- Maximum Table Output BasedOnField A5

0.081746516

! - Input Unit Type for X

!- Output Unit Type

! - Normalization Reference

1 ,

! - X Value 1

!- Output Value 1

$1.19047619, \quad !-X$ Value 2

0.078476655 .

!- Output Value 2

Table: TwoIndependentVariables,
FullLoadClgCapfTemp,
! - Name
Biquadratic,
! - Curve Type

LagrangeInterpolationLinearExtrapolation, !- Interpolation Method

0 ,

100 ,

0 ,

100,

'Temperature,

Temperature,

Power,

8.630943895

17.2222222222222

!- Minimum Value of X \{BasedOnField A4

! - Maximum Value of X \{BasedOnField A4\}

!- Minimum Value of Y \{BasedOnField A5

!- Maximum Value of Y \{BasedOnField A5\}

!- Minimum Table Output \{BasedOnField A6

! - Maximum Table Output \{BasedOnField A6

!- Input Unit Type for X

!- Input Unit Type for Y

! - Output Unit Type

! - Normalization Reference

! - X Value 1 
10 ,

9.49550364 ,

19.4444444444444 ,

10 ,

10.43333116

21.6666666666667 ,

10 ,

11.34185157

17.2222222222222,

15.5555555555556,

9.14381832 ,

19.4444444444444 ,

15.5555555555556 ,

10.02303162 ,

21.6666666666667 ,

15.5555555555556 ,

10.90224492 ,

17.2222222222222,

21.111111111111,

8.70421167

19.4444444444444 ,

21.1111111111111,

9.55411786 ,

21.6666666666667 , 21.1111111111111 ,

10.37471694

17.2222222222222,

26.6666666666667 ,

8.17668369 ,

19.4444444444444 ,

26.6666666666667 , 8.96797566 ,

21.6666666666667 ,

26.6666666666667 ,

9.75926763

17.2222222222222,

32.2222222222222，

7.56123438

19.4444444444444 ,

32.2222222222222 ,

8.29391213
! - Y Value 1

!- Output Value 1

! - X Value 2

! - Y Value 2

!- Output Value 2

! - X Value 3

! - Y Value 3

!- Output Value 3

! - X Value 4

! - Y Value 4

!- Output Value 4

! - X Value 5

!- Y Value 5

!- Output Value 5

! - X Value 6

!- Y Value 6

!- Output Value 6

! - X Value 7

! - Y Value 7

!- Output Value 7

! - X Value 8

!- Y Value 8

!- Output Value 8

! - X Value 9

!- Y Value 9

! - Output Value 9

! - X Value 10

! - Y Value 10

!- Output Value 10

! - X Value 11

! - Y Value 11

! - Output Value 11

! - X Value 12

! - Y Value 12

!- Output Value 12

! - X Value 13

!- Y Value 13

!- Output Value 13

! - X Value 14

! - Y Value 14

!- Output Value 14 


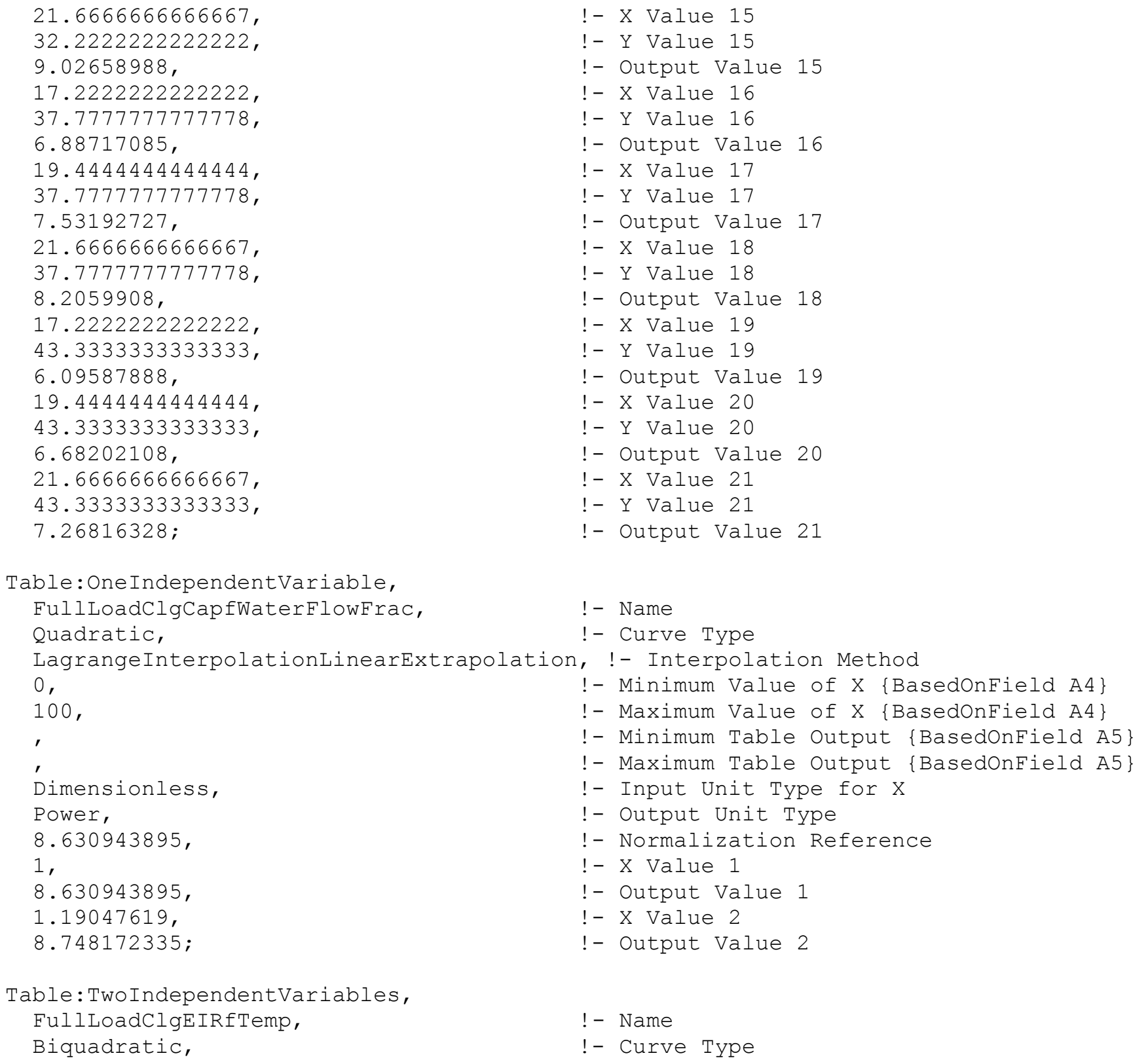

Table: OneIndependentVariable, FullLoadClgCapfWaterFlowFrac, Quadratic,

! - Name ! - Curve Type

LagrangeInterpolationLinearExtrapolation, !- Interpolation Method 0 ,

! - Minimum Value of X \{BasedOnField A4 100

!- Maximum Value of X \{BasedOnField A4

!- Minimum Table Output \{BasedOnField A5

!- Maximum Table Output \{BasedOnField A5\}

'Dimensionless,

Power,

8.630943895 ,

1 ,

!- Input Unit Type for $\mathrm{X}$

! - Output Unit Type

! - Normalization Reference

8.630943895

1.19047619,

8. 748172335 ;

! - X Value 1

! - Output Value 1

! - X Value 2

!- Output Value 2

Table: TwoIndependentVariables,

FullLoadClgEIRfTemp,

Biquadratic,

! - Name

! - Curve Type 


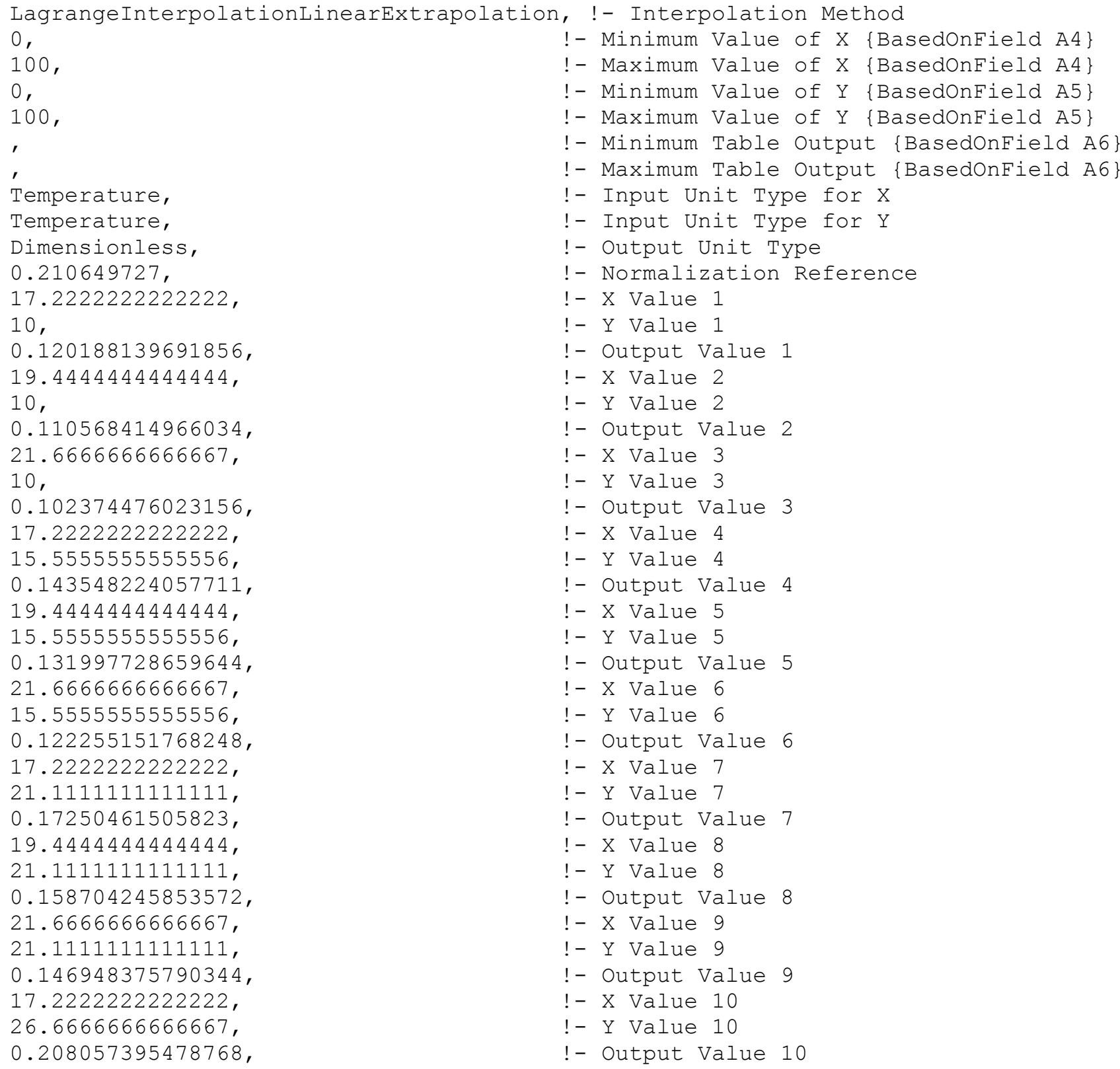

!- Output Value 10 


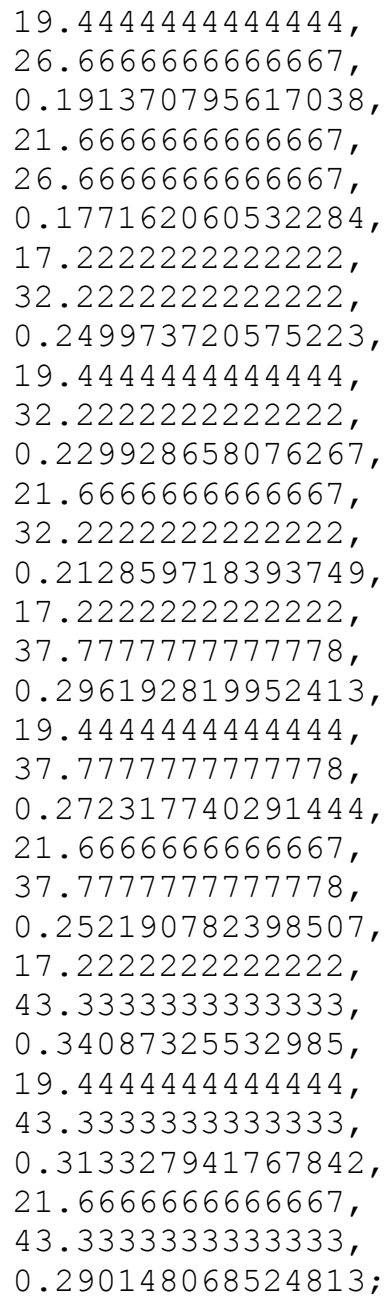

Table:OneIndependentVariable,
FullLoadClgEIRfWaterFlowFrac,
Quadratic,
!- Curve Type
0 ,
100
!- Minimum Value of $X$ \{BasedOnField A4\}
! - Maximum Value of X \{BasedOnField A4

! - X Value 11

! - Y Value 11

!- Output Value 11

! - X Value 12

! - Y Value 12

! - Output Value 12

! - X Value 13

! - Y Value 13

!- Output Value 13

! - X Value 14

! - Y Value 14

!- Output Value 14

! - X Value 15

! - Y Value 15

!- Output Value 15

! - X Value 16

!- Y Value 16

!- Output Value 16

! - X Value 17

! - Y Value 17

! - Output Value 17

! - X Value 18

! - Y Value 18

!- Output Value 18

! - X Value 19

! - Y Value 19

!- Output Value 19

! - X Value 20

! - Y Value 20

!- Output Value 20

! - X Value 21

!- Y Value 21

!- Output Value 21
!- Minimum Table Output BasedOnField A5 
Dimensionless,

Dimensionless,

0.210649748 ,

1 ,

0.210649748

1.19047619,

0.202176841
!- Maximum Table Output BasedOnField A5

!- Input Unit Type for X

! - Output Unit Type

! - Normalization Reference

! - X Value 1

! - Output Value 1

! - X Value 2

!- Output Value 2 